Adriana Takahasi

\title{
Ecologia da vegetação em bancadas lateríticas em Corumbá, MS
}

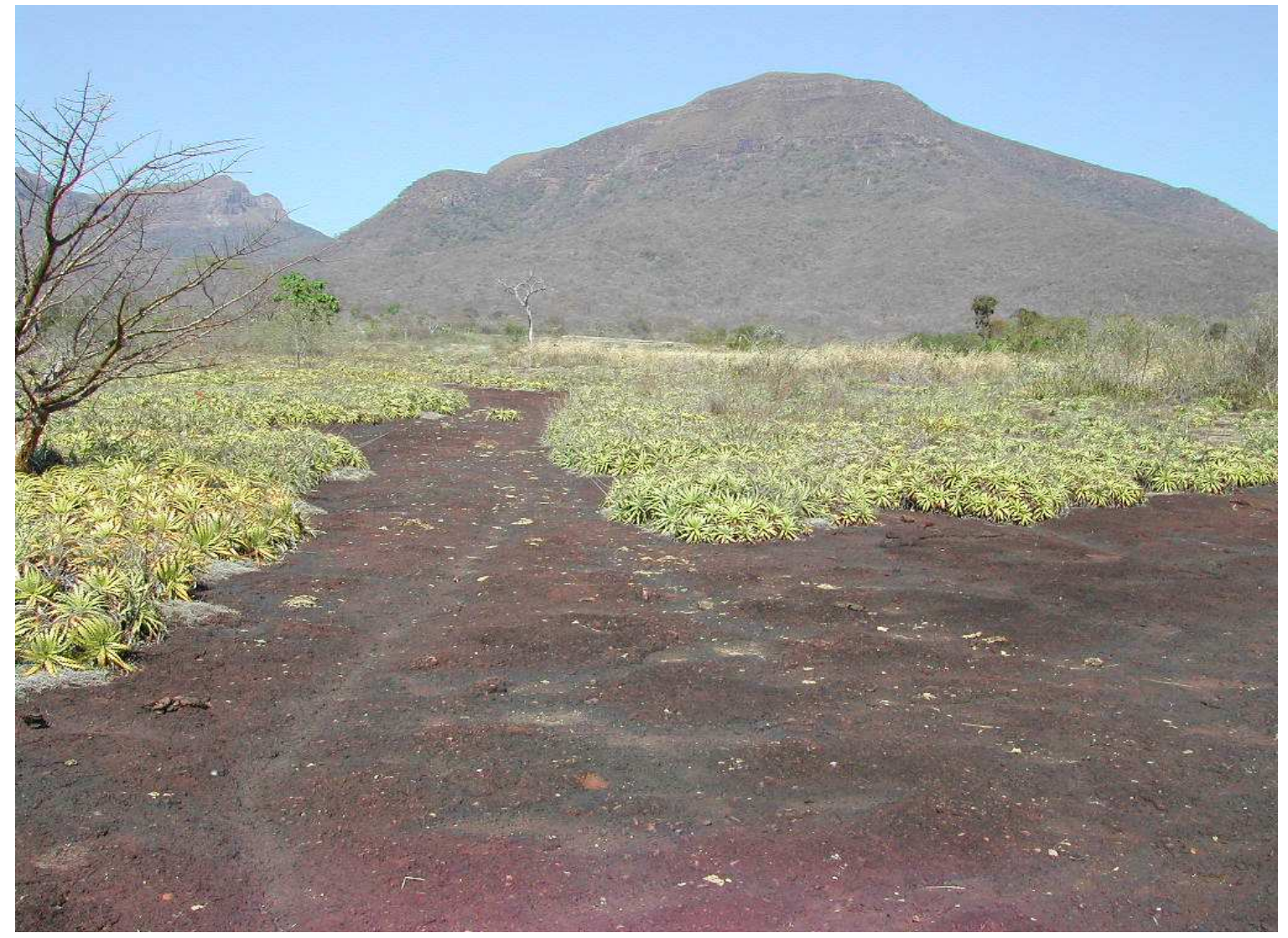

Bancadas lateríticas na Fazenda Banda Alta, Ladário, MS

São Paulo - SP

2010 
Adriana Takahasi

\section{Ecologia da vegetação em bancadas lateríticas em Corumbá, MS}

Tese apresentada ao Instituto de Biociências da Universidade de São Paulo, para a obtenção de Título de Doutor em Ecologia.

Orientador: Prof. Dr. Sergio Tadeu Meirelles

São Paulo - SP

2010 


\section{Ficha Catalográfica}

Takahasi, Adriana

Ecologia da vegetação em bancadas lateríticas em Corumbá, MS

$255 \mathrm{p}$.

Tese (Doutorado) - Instituto de Biociências da Universidade de São Paulo.

Departamento de Ecologia.

1. afloramento rochoso 2. Canga hematítica 3. campo ferruginoso I. Universidade de São Paulo. Instituto de Biociências. Departamento de Ecologia.

Comissão Julgadora:

Prof(a). Dr(a).

Prof(a). Dr(a).
Prof(a). Dr(a).

\footnotetext{
Prof(a). $\operatorname{Dr}(a)$.
}

Prof. Dr. Sergio Tadeu Meirelles

Orientador 


\section{Dedicatória}

A minha mãe e irmãs pelo amor e apoio 


\section{Um koan}

Po-chang tinha tantos alunos que se viu obrigado a abrir outro mosteiro. Para achar alguém apto a ser mestre na nova casa, juntou seus monges $e$ colocou um cântaro na frente deles, dizendo:

- Sem o chamarem de cântaro, me digam o que é isso.

- Você não pode chamá-lo um pedaço de lenha, disse o monge principal.

Nesta altura, o cozinheiro do mosteiro derrubou o cântaro com um pontapé e afastou-se.

Po-chang deu a direção do novo mosteiro ao cozinheiro. 


\section{Agradecimentos}

Ao meu orientador, Sergio, pela oportunidade de estudar e apreciar a beleza inóspita dos afloramentos rochosos, pela grande amizade, compreensão e paciência por todo esse período;

Aos proprietários das Fazendas que permitiram o acesso às áreas de estudo, Sami Lofti, Mestre Altair e José Carlos;

Ao curso de pós-graduação em Ecologia da USP, professores e funcionários do Departamento, bem como os funcionários da secretaria de pós-graduação do Instituto de Biociências e professores do Departamento de Botânica da USP;

A UFMS por conceder a licença para conclusão do doutorado, pela infraestrutura e apoio logístico e, especialmente, aos funcionários Diomar Ribeiro, Dejair, Denilson Almeida e Delfino;

A CAPES pela bolsa de estudos durante parte do período;

A Iria Ishii, curadora do Herbário COR, da UFMS campus Pantanal pelo profissionalismo e grande amizade;

Ao Geraldo Damasceno pelas discussões e apoio no início do projeto, inclusive na escolha das áreas estudadas;

Aos colegas do CPAN e, principalmente, aos professores do curso de Biologia do Departamento Ciências do Ambiente: Maria Angélica Bezerra, Ieda Bortolotto, Marcelo Bordignon, Vanda Ferreira, Fabiana Zanoelo, Marivaine Brasil e aos técnicos: Ramona, Lecir, Glauter e Marquito;

Aos alunos da Biologia da UFMS que ajudaram na coleta de dados em campo (e foram muitos!) agradeço de todo coração: Sonia Ribas, Maria Luiza Bento de Jesus Filha, Edvania Brandão da Silva, Flavio Papa, Marcus Vinícius Urquiza, Rosa Helena Silva, Marcos Mendes, Rogério, Ednael e Vitor Nantes;

Aos colegas de pós-graduação da USP e, em especial: Maura Albergaria, Maurício, Benoit, Miltinho, Cris, Maria Claudia, Olidan, além da Joyce, Viviane e Hellen; Ao Wagner meu companheiro por todo o sempre, razão para chegar até o fim e persistir e não desistir mesmo quando tudo parecia sem solução;

A Maria Augusta, pela acolhida carinhosa, e a minha mãe e irmãs por acreditar que ainda tenho jeito. 


\section{Sumário}

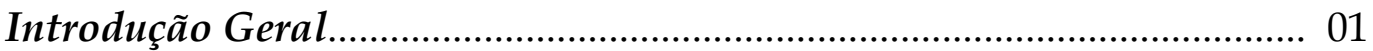

Referências Bibliográficas............................................................... 10

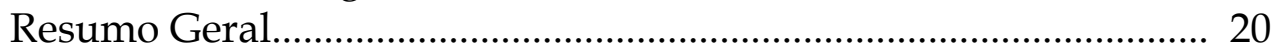

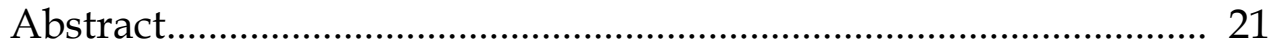

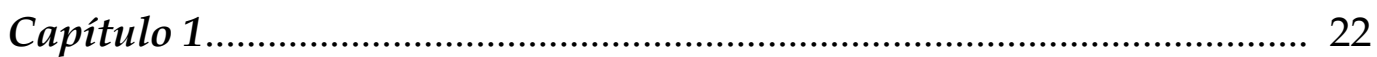

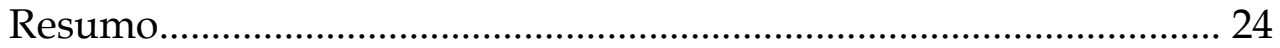

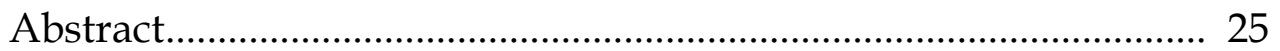

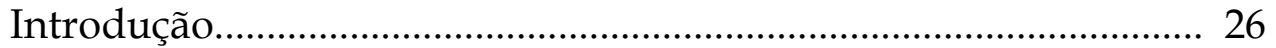

Material e Métodos............................................................... 34

Área de estudo...................................................................... 34

Delimitação da amostragem.................................................... 37

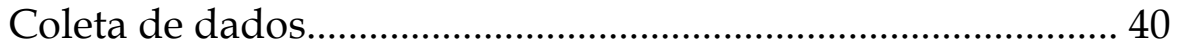

Parâmetros fitossociológicos..................................................... 40

Fisionomia: formas de vida e desenhos esquemáticos

da vegetação.......................................................................... 42

Suficiência amostral.............................................................. 43

Análises de ordenação................................................................. 43

Composição e cobertura de espécies em função do tamanho

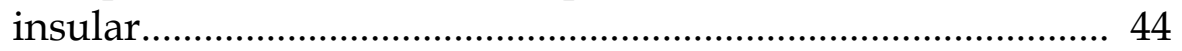

Riqueza versus área insular.................................................. 45

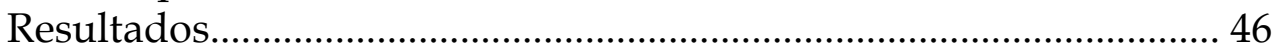

1. Composição florística das bancadas lateríticas...................... 46

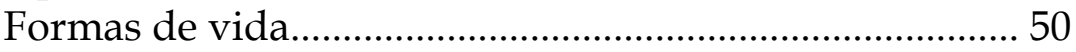

2.Estrutura da vegetação herbácea amostrada

em parcelas de 1 x 1 m........................................................ 52

Formas de vida................................................................ 59

Habitats "seco" e "encharcado" da Fazenda

Banda Alta........................................................................ 64

Análises de ordenação para a vegetação

amostradas em parcelas de 1 x 1 m.................................. 65

Fazenda Banda Alta.......................................................... 65

Fazenda São Sebastião do Carandá................................ 70

Fazenda Monjolinho........................................................... 74

3.Estrutura da vegetação em ilhas de solo.............................. 78

Formas de vida......................................................... 82

Análises de ordenação para a vegetação amostrada

em ilhas de solo............................................................. 87

Fazenda Banda Alta...................................................... 87

Fazenda São Sebastião do Carandá............................... 91

Fazenda Monjolinho..................................................... 95

4.Relação entre tamanho insular e riqueza de espécies.......... 100

5.Relação entre a composição e cobertura das espécies 
nas ilhas de solo e a classe de tamanho.

6. Relação entre o grau de cobertura de espécies vasculares em ilhas de solo e as classes de tamanho..................................... 108

Discussão

Florística dos afloramentos rochosos ferruginosos

de Corumbá

Estrutura da vegetação do estrato herbáceo nos

afloramentos rochosos

Estrutura da vegetação em ilhas de solo nos

afloramentos rochosos.

Características da comunidade............................................... 127

Formas de vida............................................................... 127

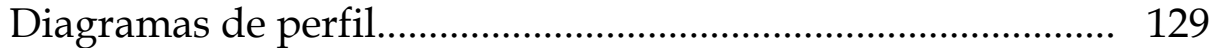

Diversidade e equabilidade........................................................ 130

Gradiente ambiental para a vegetação do estrato

herbáceo dos afloramentos rochosos ferruginosos.................... 131

Gradiente ambiental para a vegetação em ilhas de solo dos

afloramentos rochosos ferruginosos

Características das ilhas de solo

Relação entre tamanho insular e riqueza de espécies nas ilhas de solo.

Relação entre classe de tamanho e cobertura das espécies nas ilhas de solo.

A vegetação em ilhas de solo em função das classes

de tamanho

Aspectos sucessionais nas ilhas de solo em afloramentos

rochosos ferruginosos.

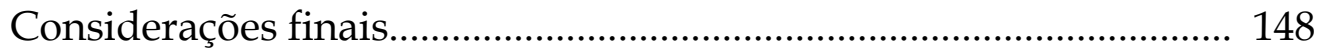

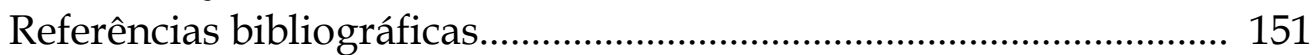

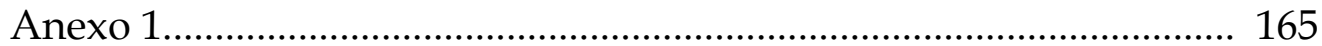

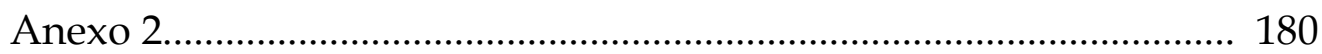

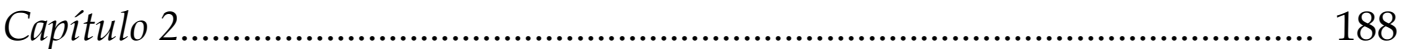

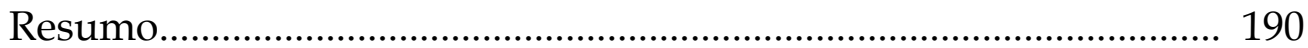

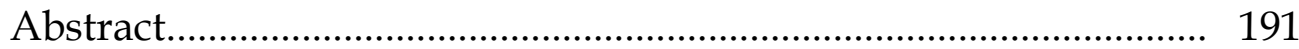

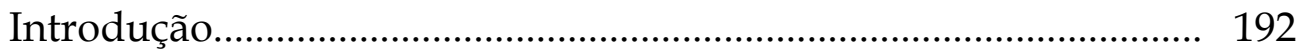

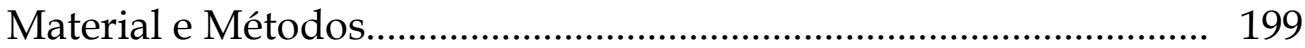

Área de estudo............................................................... 199

Coleta de dados................................................................ 202

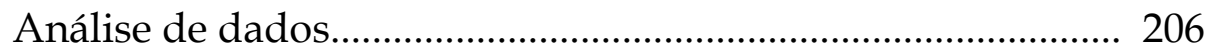

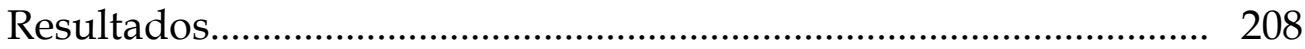

Análise florística para as famílias amostradas em

afloramentos rochosos........................................................ 208

Análise florística para os gêneros amostrados em

afloramentos rochosos............................................................... 214

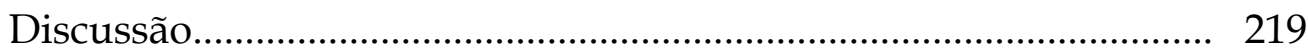


Análise florística.................................................................... 219

Similaridade florística dos afloramentos rochosos................ 220

Análises de ordenação.......................................................... 221

Características ambientais dos afloramentos rochosos......... 225

Considerações finais................................................................. 229

Referências bibliográficas............................................................ 232

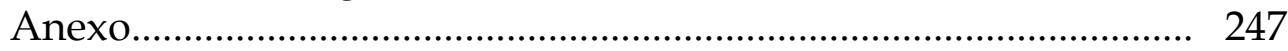

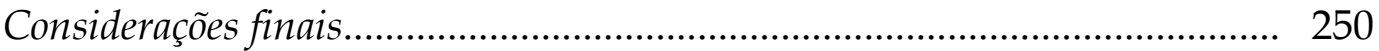

Referências bibliográficas........................................................... 254

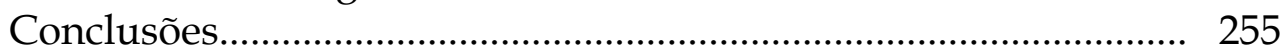




\section{Introdução Geral}

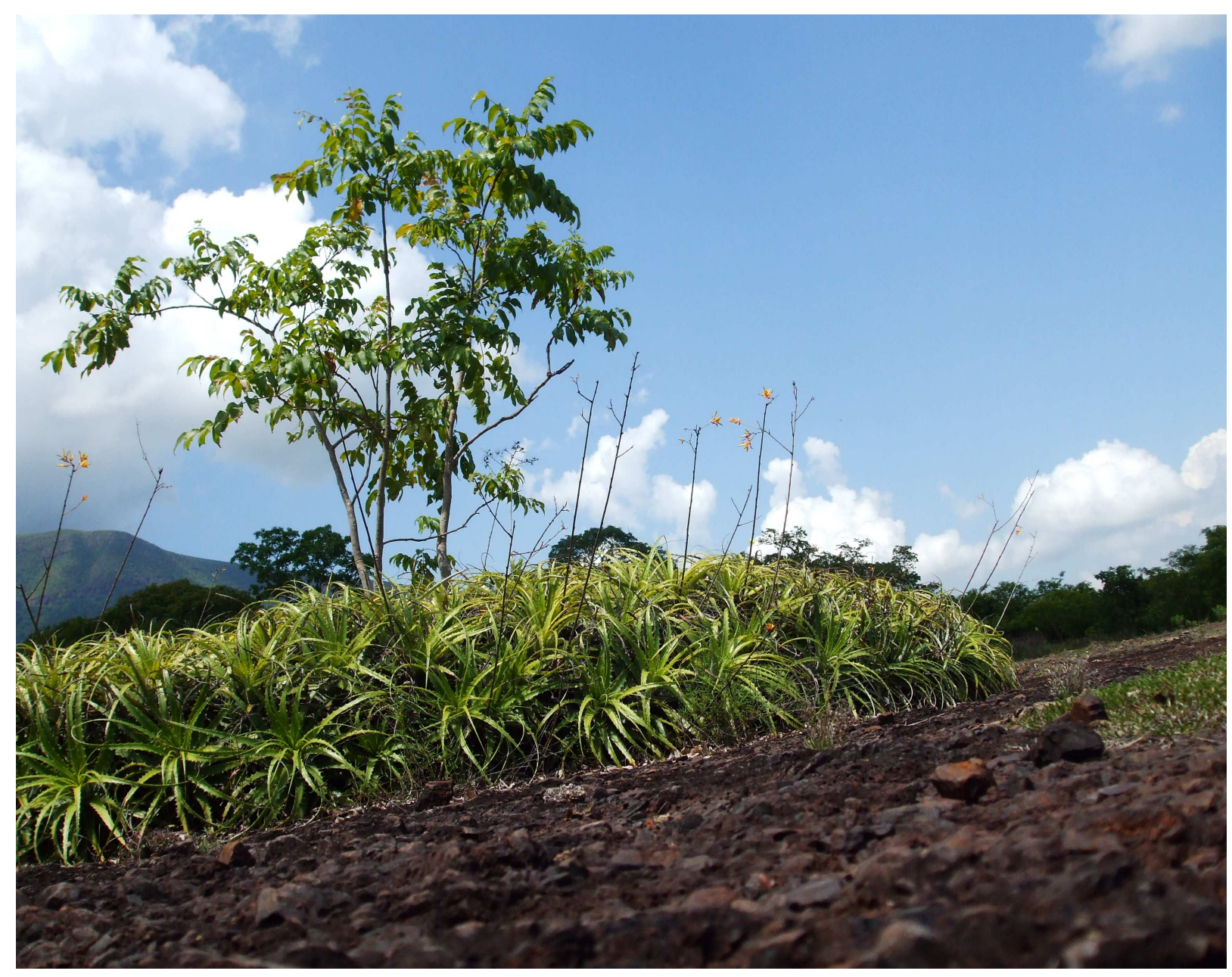

Ilha de solo com Deuterocohnia meziana Meze

Astronium fraxinifolium Schott na Fazenda Banda Alta, Ladário, MS 
As condições ambientais extremamente adversas nos afloramentos rochosos, como a grande amplitude diária de temperatura, as altas taxas de insolação e de evaporação (Porembski et al. 1998), e, especialmente, a inexistência ou exiguidade do solo, o que não permite o armazenamento de água no solo durante a estação seca (Sarthou et al. 2009), restringem a ocupação a um grupo limitado de plantas.

Face à heterogeneidade ambiental dos afloramentos rochosos constatam-se duas formas de ocupação: plantas colonizando a superfície da rocha (epilíticas) e aquelas em ilhas de solo. Vários agrupamentos de vegetação são dominados por uma única espécie, como as manchas de Selaginella spp. e de monocotiledôneas (Orchidaceae, Poaceae, Bromeliaceae, Velloziaceae), embora possam surgir moitas com composição variada e plantas de maior porte, como as ilhas de arbustos e de cactos (Ibisch et al. 1995), uma vez que as condições físicas desfavoráveis são amenizadas nos agrupamentos de vegetação (Conceição et al. 2007a). Algumas espécies da América do Sul são típicos constituintes de comunidades de ilhas de solo, como os gêneros Pitcairnia, Selaginella, Vellozia e Vriesea (Porembski et al. 1998).

A distribuição das espécies no interior dos afloramentos rochosos normalmente está relacionada à microtopografia, à presença de nichos mais úmidos ou mais secos, além da ação do fogo (Hambler 1964). São descritos diferentes tipos de habitats: superfícies expostas de rocha, efêmeras depressões de rochas cheias de água durante a estação chuvosa, canais de drenagem, agrupamentos de monocotiledôneas e vegetação em locais úmidos (Barthlott et al. 
1993). Porembski et al. (1994) acrescentam, ainda, fendas de rocha; depressões de pedra (com camada fina de solo); manchas de plantas monoespecíficas; vegetação efêmera e florestas semideciduais nos afloramentos.

As condições ambientais extremas proporcionam similaridades fisionômicas e florísticas e suas espécies possuem adaptações para sobreviver a condições oligotróficas, como as plantas suculentas ou as poiquiloídricas (Porembski et al. 1994). Algumas espécies típicas de afloramentos rochosos apresentam uma ampla distribuição, como o caso de Selaginella convoluta (Arn.) Spring e S. sellowii Hieron, características dos inselbergs do Brasil (Ibisch et al. 1995).

As plantas que se estabelecem nos afloramentos rochosos na América do Sul podem ser enquadradas, basicamente, em quatro grupos funcionais: espécies que formam agrupamentos (como as bromélias), espécies suculentas ou com caules volumosos (como em Bombacaceae e Bignoniaceae), espécies com adaptações para sobreviver ao fogo (como órgãos subterrâneos ou caules cobertos por raízes e bainhas foliares como em Arecaceae) (Barthlott et al. 1993), além de samambaias poiquiloídricas dos gêneros Selaginella, Doryopteris e Anemia (Gaff 1987). Espécies de angiospermas poiquiloídricas são raras, como por exemplo: Afrotrilepis (Cyperaceae), Velloziaceae e Scrophulariaceae na África (Barthlott et al. 1993).

A restrição ambiental limita o número de espécies estabelecidas nestes locais e pode contribuir ao isolamento reprodutivo destas populações conferindo um elevado grau de endemismo a estes ambientes (Porembski 2007). No Brasil, isso parece ser consistente para espécies saxícolas dos gêneros Coleocephalocereus, 
Melocactus (Cactaceae) (Barthlott et al. 1993, Porembski et al. 1998) e Alcantarea (Bromeliaceae) (Porembski et al. 1998), assim como para Velloziaceae (Barthlott et al. 1993), destacando-se a ocorrência do centro de dispersão para estes dois últimos táxons no sudeste brasileiro.

Os afloramentos rochosos do leste do Brasil parecem ser fitogeograficamente isolados e mais ricos em espécies, destacando-se a ocorrência de táxons saxícolas de Velloziaceae, Bromeliaceae, Cactaceae, Orchidaceae e samambaias (Porembski et al. 1998). Meirelles et al. (1999) encontraram um alto grau de endemismo em sítios rochosos no Rio de Janeiro, assim como Conceição \& Pirani (2007) observou na Chapada Diamantina, BA. Outros autores apontam que a vegetação nos afloramentos rochosos apresenta poucos endemismos, com várias espécies que típicas de formações pioneiras abertas, com maior ou menor contato com rochas (Ibisch et al. 1995, Sarthou et al. 2009).

Os trabalhos em comunidades insulares nos afloramentos rochosos tropicais têm abordado desde aspectos da sucessão vegetal (Hambler 1964; Ibisch et al. 1995); de sazonalidade da diversidade (Porembski \& Barthlott 1997); de relação entre tamanho da ilha e a diversidade (Barthlott et al. 1993; Porembski et al. 1995), além de considerações sobre a distribuição das espécies que ocorrem nos afloramentos e seu grau de endemismo (Porembski et al. 1994).

Entretanto, na América do Sul os trabalhos são bem mais recentes, destacando-se os estudos de levantamento de espécies e aspectos biogeográficos na Venezuela (Groger 1994, Groger \& Barthlott 1996; Michelangeli 2000); na Venezuela e Guiana (Barthlott et al. 1993); na Guiana Francesa (Sarthou et al. 2003, 2009); na Colômbia (Arbeláez \& Druvenvoorden 2004), na Argentina (Carretero 
1999) e na Bolívia (Ibisch et al. 1995; Mostacedo et al. 2001). No Brasil destacam-se os estudos em afloramentos rochosos na Serra do Mar (Carauta \& Oliveira 1984, Meirelles 1990, Meirelles 1996, Porembski et al. 1998, Meirelles et al. 1999), na Serra da Mantiqueira, incluindo a Cadeia do Espinhaço (Giulietti et al. 1987, Peron 1989, Conceição \& Giulietti 2002, Zappi et al. 2003, Conceição \& Pirani 2005, Caiafa \& Silva 2005, 2007, Ribeiro et al. 2007, Conceição et al. 2007a, b, Neves \& Conceição 2007), no interior de São Paulo (Oliveira \& Godoy 2007) e em alguns afloramentos rochosos no Rio Grande do Sul (Fernandes \& Baptista 1988, 1999, Waldemar 1998, Bauer \& Larocca 2003). No interior do Brasil, ressaltam-se os estudos em afloramentos rochosos no semi-árido brasileiro (França et al. 1997, 2005, 2006, Queiroz et al.1996, Araújo et al. 2005, Araújo et al. 2008, Porto et al. 2008, Gomes \& Alves 2009, Silva et al. 2009) e alguns estudos em cangas lateríticas na Serra do Carajás (Secco \& Mesquita 1983, Silva et al. 1996, Rayol 2006) e na região do Quadrilátero Ferrífero em MG (Brandão \& Gavilanes 1990, Jacobi et al. 2007, 2008, Mourão \& Stehmann 2007, Viana \& Lombardi 2007, Vincent \& Meguro 2008) mas nenhum trabalho na região de Corumbá, MS.

A diversidade de litologias, influenciando a decomposição da rocha e, por sua vez, a formação de microtopografias, o regime climático, o tipo de vegetação circundante e relevo, entre outros, determina a diversidade e complexidade das comunidades sobre afloramentos rochosos. Isto pode dificultar a uniformização da metodologia aplicada aos afloramentos. E, talvez por este motivo vários estudos utilizem, simplesmente, vegetação sobre afloramentos rochosos ("rock outcrop vegetation") para designar estas comunidades. 
O termo "inselberg" também é usado em diversos estudos para delimitar este tipo de ambiente, como p.ex. Porembski e colaboradores. Entretanto, este termo possui um significado muito particular oriundo da geologia definido como: formas residuais rochosas desprovidas de manto de alteração, ocorrendo como colinas isoladas ou grupos de montanhas, características de paisagens tropicais, especialmente as savanas, com vertentes íngremes cujo contato com o plano adjacente é abrupto originado a partir do recuo paralelo das vertentes durante os processos de pedimentação ou pediplanação (Bigarella 2007). Podem ser de dois tipos: forma dômica (pão-de-açúcar, pontão, “bornhardt") e forma de grandes matacões ("tors") (Bigarella 2007).

Uma das questões centrais da ecologia é explicar a diversidade de espécies nas comunidades. Uma das hipóteses para explicar este problema é através de mecanismos de coexistência, presumindo-se que a maioria dos organismos potenciais de uma comunidade estão presentes ou, ao menos, tiveram a oportunidade de colonizá-las mas foram excluídas por competição (Eriksson 1993). Outra hipótese aventada é a de que a diversidade atual é resultado de processos de especiação e extinção que ocorreram ao longo do processo evolutivo. A partir desta última surgiu a teoria de "species-pool" onde a diversidade local é explicada pelo tamanho da fonte de espécies em escala global ou regional, desde que a idade geológica local tenha permitido a oportunidade de especiação e a formação de um número de espécies disponíveis adaptadas a dado habitat determinando a diversidade local (Eriksson 1993).

A teoria de equilíbrio de biogeografia de ilhas proposta por MacArthur \& Wilson $(1963,1967)$ foi um marco na biologia ao propor que em sistemas 
biológicos discretos e isolados o número de espécies em qualquer tempo será uma função do número prévio de espécies mais aquele ganho por imigração e/ou especiação menos as espécies extintas localmente. Estes processos são controlados por dois fatores ambientais principais: isolamento e área (MacArthur \& Wilson 1967). Outros fatores também podem se tornar relevantes, como a elevação e a latitude (Simberloff 1974, Connor \& McCoy 1979, Hillebrand 2004, Hannus \& Numers 2008), além da forma da ilha e a heterogeneidade.

A relação espécie-área é um dos métodos mais frequentes para se estimar o número de espécies em diferentes escalas espaciais (Connor \& McCoy 1979, Houle 1990, Lomolino 2000, Michelangeli 2000, Lawson \& Jensen 2006), sendo utilizada para o planejamento ambiental ao prever a perda de espécies em função da perda de habitats (Ulrich \& Buszko 2004, Ulrich 2005). A relação entre o número de espécies observadas em um local e a sua área é uma questão teórica ainda sujeita a muito debate (Lomolino \& Wiser 2001, Triantis et al. 2003, Ulrich 2005, Lawson \& Jensen 2006, Baldi 2008, Hannus \& Numers 2008).

Os modelos mais conhecidos e utilizados são: a curva potência (Arrhenius 1921, 1923) e a curva exponencial (Gleason 1922, 1925), geralmente transformadas nos modelos log-log e log-linear. A função potência é o modelo mais utilizado para descrever a relação espécie-área, sendo expressa pela fórmula: $\mathrm{S}=\mathrm{C} \cdot \mathrm{A}^{\mathrm{z}}$, onde S representa a riqueza de espécies, A representa a área, C e z são constantes. Já a função exponencial pode ser expressa pela fórmula: $S=\log C+z \cdot \log A$ (Connor \& McCoy 1979).

Alguns trabalhos em afloramentos rochosos têm buscado relações entre o tamanho das ilhas de solo e a diversidade. Barthlott et al. (1993) observaram que a 
composição e a diversidade de espécies nos afloramentos rochosos da Costa do Marfim foram constantes, independente do aumento do tamanho do afloramento, contrariando um princípio da biogeografia de ilhas. Entretanto, os autores sustentam que afloramentos rochosos maiores podem conter populações maiores e mais estáveis, sendo menos afetadas por influências deletérias como o fogo. Michelangeli (2000) e Houle (1990) verificaram uma correlação positiva entre tamanho da ilha e a riqueza de espécies, em rochas areníticas ('tepuis') e em rochas graníticas, respectivamente, cujo melhor modelo preditório foi a função exponencial. Michelangeli (2000) sugeriu que a disponibilidade de nutrientes foi o fator limitante para determinar a composição de espécies e a diversidade das comunidades enquanto Houle (1990) destacou que a riqueza de espécies foi influenciada pela área em ilhas em estágios sucessionais tardios.

No Brasil, poucos trabalhos descrevem a vegetação em afloramentos rochosos que ocorre sob forma agrupada em ilhas de solo, destacando-se os estudos na Serra do Mar (Meirelles et al. 1999) e no Planalto Itatitaia (Ribeiro et al. 2007), ambos no Rio de Janeiro, na Chapada Diamantina, na Bahia (Conceição et al. 2007a, b) e no nordeste do estado de São Paulo (Oliveira \& Godoy 2007).

As 'cangas' são descritas por Castro (2008) como rochas ferruginosas formadas por material detrítico derivado de rochas próximas ricas em ferro, normalmente compostas por lâminas de hematita e quartzo interestratificados, como os itabiritos, ou, no lugar de quartzo, podem ocorrer dolomita e anfibólios. Destaca-se a importância de chuvas sazonais para o processo de intemperismo propiciando dissolução e reprecipitação de minérios de ferro durante os milhares de ano necessários para a formação das crostas de canga (Castro 2008). A 
ocorrência de cangas no Brasil está restrita às regiões serranas: Serra de Carajás (PA), Corumbá (MS), Quadrilátero Ferrífero, Serro e Capelinha (MG).

As cangas de Carajás e do Quadrilátero Ferrífero ocorrem preferencialmente em altos topográficos (Castro 2008), diferentemente de Corumbá onde as cangas afloram em níveis topográficos inferiores.

Em Corumbá, MS, os afloramentos rochosos ferríferos, também denominados bancadas lateríticas, ocorrem nas áreas de drenagem (em torno de 100 m de altitude) das Morrarias do Urucum e do Rabicho. As bancadas lateríticas constituem um relevo e não um tipo de solo, apresentando-se plano ou quase plano, formadas por camada de material laterítico endurecido, de natureza ferrífera (Cardoso et al. 2000).

O capítulo 1 analisa a composição e a estrutura da vegetação nos afloramentos rochosos ferruginosos de Corumbá, MS, destacando as diferenças entre a vegetação do estrato herbáceo daquela em ilhas de solo. Também verifica como os valores de cobertura e a composição de espécies varia em função do tamanho da ilha de solo, bem como varia a riqueza específica.

O capítulo 2 compara a vegetação de Corumbá, nos níveis taxonômicos de famílias e gêneros, com as de outros afloramentos rochosos do Brasil através da análise de cluster e avalia, através de procedimentos de ordenação, se os diferentes locais segregam-se em função da litologia dominante. 


\section{Referências bibliográficas}

ARAÚJO, E.L.; SILVA, K.A.; FERRAZ, E.M.N.; SAMPAIO, E.V.S.B. \& SILVA, S.I. 2005. Diversidade de herbáceas em microhabitats rochoso, plano e ciliar em uma área de caatinga, Caruaru, PE, Brasil. Acta Botanica Brasilica, v.19, n.2, p.285-294 ARAÚJO, F.S.; OLIVEIRA, R.F. \& LIMA-VERDE, L.W. 2008. Composição, espectro biológico e síndromes de dispersão da vegetação de um inselbergue no domínio da caatinga, Ceará. Rodriguésia, v.59,n.4, p.659-671.

ARBELÁEZ, M.V. \& DUIVENVOORDEN, J.F. 2004. Patterns of plant species composition on Amazonian sandstone outcrops in Colombia. Journal of Vegetation Science, v.15, p.181-188

ARRHENIUS, O. 1921. Species and area. The Journal of Ecology, v.9, n.1, p.95-99, set.

ARRHENIUS, O. 1923. On the relation between species and area - a reply. Ecology, v.4, n.1, p.90-91, jan.

BÁLDI, A. 2008. Habitat heterogeneity overrides the species-area relationship. Journal of Biogeography, v.35, p.675-681

BARTHLOTT, W., GROGER, A. \& POREMBSKI, S. 1993. Some remarks on the vegetation of tropical inselbergs: diversity and ecological differentiation. Biogéographica, v.69, n.3, p.17-36. 
BAUER, D. \& LAROCCA, J. 2003. Flora vascular rupestre de um afloramento basáltico na localidade de Fazenda Padre Eterno, RS. Pesquisas Botânica, v.53,p.101-119.

BIGARELLA, J.J.; BECKER, R.D. \& SANTOS, G.F. 2007. Estrutura e origem das paisagens tropicais e subtropicais. Vol.1. 2.ed. Florianópolis, SC: Editora da UFSC. 425p.

BRANDÃO, M. \& GAVILANES, M.L. 1990. Mais uma contribuição para o conhecimento da Cadeia do Espinhaço em Minas Gerais (Serra da Piedade) - II. Daphne, v.1,n.1,p.26-43.

CAIAFA, A.N. \& SILVA, A.F. 2005. Composição florística e espectro biológico de um campo de altitude no Parque Estadual da Serra do Brigadeiro, Minas Gerais, Brasil. Rodriguésia, v.56,n.87,p.163-173

CAIAFA, A.N. \& SILVA, A.F. 2007. Structural analysis of the vegetation on a highland granitic rock outcrop in Southeast Brazil. Revista Brasileira de Botânica, v.30,n.4,p.657-664.

CARAUTA, J.P.P. \& OLIVEIRA, R.R. 1984. Plantas vasculares dos morros da Urca, Pão de Açúcar e Cara de Cão. Rodriguésia v.36,n.59,p.13-24.

CARDOSO, E.L., OLIVEIRA, H., AMARAL, J.A.M., KER, J.C., PEREIRA, N.R., SANTOS, R.D., TÔSTO, S.G., SPERA, S.T. \& CARVALHO JÚNIOR, W. 2000. Pedologia. In Zoneamento ambiental da borda oeste do Pantanal: maciço do Urucum e adjacências (J.S.V. Silva, org.). Brasília, DF, Embrapa Comunicação para Transferência de Tecnologia, p.95-109. 
CARRETERO, E.M. 1999. Saxicoulous and riparian vegetation of a piedmont in central-western Argentina. Journal of Arid Environments, v.42, p.305-317.

CASTRO, P.T.A. 2008. Cangas: a influência da geodiversidade na biodiversidade. In: Jacobi, C.M. et al. (org.). I Simpósio: afloramentos ferruginosos no Quadrilátero Ferrífero: biodiversidade, conservação e perspectivas de sustentabilidade. Belo Horizonte: UFMG/ICB.

CONCEIÇÃO, A.A. \& GIULIETTI, A.M. 2002. Composição florística e aspectos estruturais de campo rupestre em dois platôs do Morro do Pai Inácio, Chapada Diamantina, Bahia, Brasil. Hoehnea, v.29,n.1,p. 37-48

CONCEIÇÃO, A.A. \& PIRANI, J.R. 2005. Delimitação de habitats em campos rupestres na Chapada Diamantina, Bahia: substratos, composição florística e aspectos estruturais. Boletim de Botânica da Universidade de São Paulo v.23,n.1,p.85-111.

CONCEIÇÃO, A.A.; GIULIETTI, A.M. \& MEIRELLES, S.T. 2007a. Ilhas de vegetação em afloramentos de quartzito-arenito no Morro do Pai Inácio, Chapada Diamantina, Bahia, Brasil. Acta Botanica Brasilica v.21, n.2, p.335-347

CONCEIÇÃO, A.A.; PIRANI, J.R. \& MEIRELLES, S.T. 2007b. Floristics, structure and soil of insular vegetation in four quartzite-sandstone outcrops of "Chapada Diamantina", northeast Brazil. Revista Brasileira de Botânica v.30, n.4, p.641-656, out.-dez.

CONNOR, E.F. \& McCOY, E.D. 1979. The statistics and biology of the species-area relationship. The American Naturalist, v.113, n.6, p.791-833, jun. 
FERNANDES, I. \& BAPTISTA, L.R.M. 1988. Levantamento da flora vascular rupestre do Morro Sapucaia e Morro do Cabrito, Rio Grande do Sul. Acta botanica brasilica v.1,n.2,p.95-102, supl.

FERNANDES, I. \& BAPTISTA, L.R.M. 1999. Inventário da flora rupestre e pararupestre de "Casa de Pedra", Bagé, Rio Grande do Sul. Pesquisas Botânica v.49,p.53-70.

FRANÇA, F., MELO, E. \& SANTOS, C.C. 1997. Flora de inselbergs da região de Milagres, Bahia, Brasil: I. Caracterização da vegetação e lista de espécies de dois inselbergs. Sitientibus v.17, p.163-184.

FRANÇA, F., MELO, E., SANTOS, A.K.A., MELO, J.G.A.N., MARQUES, M., SILVA-FILHO, M.F.B., MORAES, L. \& MACHADO, C. 2005. Estudos ecológico e florístico em ilhas de vegetação de um inselberg no semi-árido da Bahia, Brasil. Hoehnea, v.32, n.1, p.93-101.

FRANÇA, F.; MELO, E. \& GONÇALVES, J.M. 2006. Aspectos da diversidade da vegetação no topo de um inselbergue no semi-árido da Bahia, Brasil. Sitientibus, série Ciências Biológicas, v.6, n.1, p.30-35

GIULIETTI, A.M., MENEZES, N.L., PIRANI, J.R., MEGURO, M. \& WANDERLEY, M.G.L. 1987. Flora da Serra do Cipó, Minas Gerais: caracterização e lista das espécies. Boletim de Botânica da Universidade de São Paulo v.9,p.1-151.

GLEASON, H.A. 1925. Species and Area. Ecology, v.6, n.1, p.66-74, jan., GLEASON, H.A. 1922. On the relationship between species and area. Ecology, v.3, p.158-162. 
GOMES, P. \& ALVES, M. 2009. Floristic and vegetation aspects of an inselberg in the semi-arid region of Northeast Brazil. Edinburgh Journal of Botany, v.66, n.2, p.329-346.

GRÖGER, A. \& BARTHLOTT, W. 1996. Biogeography and diversity of the inselberg (laja) vegetation of southern Venezuela. Biodiversity Letters, v.3, n.6, p.165-179, nov.

GRÖGER, A. 1994. Analisis preliminar de la florula y vegetacion del Monumento Natural "Piedra la Tortuga", estado Amazonas, Venezuela. Acta Botanica Venezuelica, v.17, n.1,2,3,4, p.128-153.

HAMBLER, D.J. 1964. The vegetation of granitic outcrops in western Nigeria. Journal of Ecology v.52, p.573-594

HANNUS, J.J. \& von NUMERS, M. 2008. Vascular plant species richness in relation to habitat diversity and island area in the Finnish Archipelago. Journal of Biogeography, v.35, p.1077-1086

HILLEBRAND, H. 2004. On the generality of the latitudinal diversity gradient. The American Naturalist, v.163, n.2, p.192-211, fev.

HOULE, G. 1990. Species-area relationship during primary succession in granite outcrop plant communities. American Journal of Botany, v.77, n.11, p.1433-1439 IBISCH, P.L., RAUER, G., RUDOLPH, D. \& BARTHLOTT, W. 1995. Floristic, biogeographical, and vegetational aspects of Pre-Cambrian rock outcrops (inselbergs) in eastern Bolivia. Flora v.190,p.299-314. 
JACOBI, C.M., CARMO, F.F., VINCENT, R.C. \& STEHMANN, J.R. 2007. Plant communities on ironstone outcrops: a diverse and endangered Brazilian ecosystem. Biodiversity and Conservation v.16,p.2185-2200.

JACOBI, C.M.; CARMO, F.F. \& VINCENT, R.C. 2008. Estudo fitossociológico de uma comunidade vegetal sobre canga como subsídio para a reabilitação de áreas mineradas no Quadrilátero Ferrífero, MG. Revista Árvore v.32, n.2, p.345-353

LAWSON, D. \& JENSEN, H.J. 2006. The species-area relationship and evolution. Journal of Theoretical Biology, v.241, p.590-600.

LOMOLINO, M.V. \& WEISER, M.D. 2001. Towards a more general species-area relationship: diversity on all islands, great and small. Journal of Biogeography, v.28, p.431-445.

LOMOLINO, M.V. 2000. A species-based theory of insular zoogeography. Global Ecology \& Biogeography, v.9, p.39-58.

MacARTHUR, R.H. \& WILSON, E.O. 1963. An equilibrium theory of insular zoogeography. Evolution, v.17, n.4, p.373-387, dez.

MacARTHUR, R.H. \& WILSON, E.O. 1967. The theory of Island Biogeography. New Jersey: Princeton University Press. 203p.

MEIRELLES, S.T. 1990. Ecologia da vegetação de afloramentos rochosos do litoral da região sudeste. Campinas: Instituto de Biologia da UNICAMP. (Dissertação de mestrado). 
MEIRELLES, S.T. 1996. Estrutura da comunidade e características funcionais dos componentes da vegetação de um afloramento rochoso em Atibaia, SP. São Carlos: Centro de Ciências Biológicas e da Saúde da UFSCar. (Tese de doutorado). MEIRELLES, S.T., PIVELLO, V.R. \& JOLY, C.A. 1999. The vegetation of granite rock outcrops in Rio de Janeiro, Brazil, na the need for its protection. Environmental Conservation v.26,n.1,p.10-20.

MICHELANGELI, F.A. 2000. Species composition and species-area relationships in vegetation isolates on the summit of a sandstone mountain in southern Venezuela. Journal of Tropical Ecology, v.16, p.69-82

MOSTACEDO, B.; TOLEDO, M \& FREDERICKSEN, T.S. 2001. La vegetación de las lajas en la región de Lomerío, Santa Cruz, Bolivia. Acta Amazonica, v.31, n.1, p.11-25

MOURÃO, A. \& STEHMANN, J.R. 2007. Levantamento da flora do campo rupestre sobre canga hematítica couraçada remanescente na Mina do Brucutu, Barão de Cocais, Minas Gerais, Brasil. Rodriguésia v.58,n.4,p.775-786.

NEVES, S.P.S. \& CONCEIÇÃO, A.A. 2007. Vegetação em afloramentos rochosos na Serra do Sincorá, Chapada Diamantina, Bahia, Brasil. Sitientibus série Ciências Biológicas v.7, n.1, jan.-mar., p.36-45

OLIVEIRA, R.B. \& GODOY, S.A.P. 2007. Composição florística dos afloramentos rochosos do Morro do Forno, Altinópolis, São Paulo. Biota Neotropica 7(2) http:/ / www.biotaneotropica.org.br/v7n2/ pt/abstract?article+bn00507022007 
PERON, M.V. 1989. Listagem preliminar da flora fanerogâmica dos campos rupestres do Parque Estadual do Itacolomi - Ouro Preto/Mariana, MG. Rodriguésia, v.67, n.41, p.63-69.

POREMBSKI, S. \& BARTHLOTT, W. 1997. Seasonal dynamics of plant diversity on inselbergs in the Ivory Coast (West Africa). Botanica Acta, v.110, p.466-472

POREMBSKI, S. 2007. Tropical inselbergs: habitat types, adaptative strategies and diversity patterns. Revista Brasileira de Botânica, v.30, n.4, p.579-586

POREMBSKI, S., BARTHLOTT, W., DÖRRSTOCK, S. \& BIEDINGER, N. 1994. Vegetation of rock outcrops in Guinea: granite inselbergs, sandstone table mountains and ferricretes - remarks on species number and endemism. Flora, v.189, p.315-326.

POREMBSKI, S., MARTINELLI, G., OHLEMÜLLER, R. \& BARTHLOTT, W. 1998. Diversity and ecology of saxicolous vegetation mats on inselbergs in the Brazilian Atlantic rainforest. Diversity and Distributions v.4,p.107-119.

POREMBSKI, S.; BROWN, G. \& BARTHLOTT, W. 1995. An inverted latitudinal gradient of plant diversity in shallow depressions on Ivorian inselbergs.Vegetatio, v.117, p. 151-163

PORTO, P.A.F.; ALMEIDA, A.; PESSOA, W.J. TROVÃO, D. \& FELIX, L.P. 2008. Composição florística de um inselbergue no agreste paraibano, município de Esperança, nordeste do Brasil. Caatinga, v.21, n.2, p.214-222, abr.-jun.

QUEIROZ, L.P., SENA, T.S.N. \& COSTA, M.J.S.L. 1996. Flora vascular da Serra da Jibóia, Santa Terezinha - Bahia. I. O campo rupestre. Sitientibus, v.15, p.27-40. 
RAYOL, B.P. 2006. Análise florística e estrutural da vegetação xerofítica das savanas metalófilas na Floresta Nacional de Carajás: subsídios à conservação. Dissertação de Mestrado, Universidade Rural da Amazônia e Museu Paraense Emílio Goeldi, Pará.

RIBEIRO, K.T., MEDINA, B.M.O. \& SCARANO, F.R. 2007. Species composition and biogeographic relations of the rock outcrop flora on the high plateau of Itatiaia, SE-Brazil. Revista Brasileira de Botânica, v.30, n.4, p.623-639.

SARTHOU, C.; KOUNDA-KIKI, C.; VAÇULIK, A.; MORA, P. \& PONGE, J.-F. 2009. Successional patterns on tropical inselbergs: A case study on the Nouragues inselberg (French Guiana). Flora, v.204, p.396-407.

SARTHOU, C.; VILLIERS, J.F. \& PONGE, J.F. 2003. Shrub vegetation on tropical granitic inselbergs in French Guiana. Journal of Vegetation Science, v.14,p. 645652

SECCO, R.S. \& MESQUITA, A.L. 1983. Notas sobre a vegetação de canga na Serra Norte - I. Boletim do Museu Paraense Emílio Goeldi v.59,p.1-13.

SILVA, K.A.; ARAÚJO, E.L. \& FERRAZ, E.M.N. 2009. Estudo florístico do componente herbáceo e relação com solos em áreas de caatinga do embasamento cristalino e bacia sedimentar, Petrolândia, PE, Brasil. Acta Botanica Brasilica, v.23, n.1, p.100-110

SILVA, M.F.F., SECCO, R.S. \& LOBO, M.G. 1996. Aspectos ecológicos da vegetação rupestre da Serra dos Carajás, Estado do Pará, Brasil. Acta Amazonica v.26,n.1/2,p.17-44. 
SIMBERLOFF, D.S. 1974. Equilibrium theory of island biogeography and ecology. Annual Review of Ecology and Systematics, v.5, p.161-182

TRIANTIS, K.A.; MYLONAS, M.; LIKA, K. \& VARDINOYANNIS, K. 2003. A model for the species-area-habitat relationship. Journal of Biogeography, v.30, p.19-27

ULRICH, W. \& BUSZKO, J. 2004. Habitat reduction and patterns of species loss. Basic and Applied Ecology, v.5, p.231-240

ULRICH, W. 2005. Predicting species number using species-area and endemicsarea relations. Biodiversity and Conservation, v.14, p.3351-3362

VIANA, P.L. \& LOMBARDI, J.A. 2007. Florística e caracterização dos campos rupestres sobre canga na Serra da Calçada, Minas Gerais, Brasil. Rodriguesia v.58,n.1,p.159-177.

VINCENT, R.C. \&MEGURO, M. 2008. Influence of soil properties on the abundance of plant species in ferruginous rocky soils vegetation, southeastern Brazil. Revista Brasileira de Botânica, v.31, n.3, p.377-388, jul.-set.

WALDEMAR, C.C. 1998. A vegetação rupestre heliófila do Parque Estadual de Itapuã, Viamão, RS. Dissertação de mestrado, UFRGS, Rio Grande do Sul.

ZAPPI, D.C., LUCAS, E., STANNARD, B.L., LUGHADHA, E.N., PIRANI, J.R., QUEIROZ, L.P., ATKINS, S., HIND, D.J.N., GIULIETTI, A.M., HARLEY, R.M. \& CARVALHO, A.M. 2003. Lista das plantas vasculares de Catolés, Chapada Diamantina, Bahia, Brasil. Boletim de Botânica da Universidade de São Paulo v.21,n.2,p.345-398. 


\section{RESUMO}

Os afloramentos rochosos ferruginosos denominados bancadas lateríticas podem ser considerados uma paisagem peculiar no Centro-Oeste do Brasil, próximos às cidades de Corumbá e Ladário, MS. Embora situada em uma região populosa, próxima a fazendas e sítios urbanos, esta vegetação ainda é desconhecida. Neste estudo avaliamos a composição florística e a estrutura da comunidade, bem como suas relações florísticas com outros afloramentos rochosos. O levantamento foi

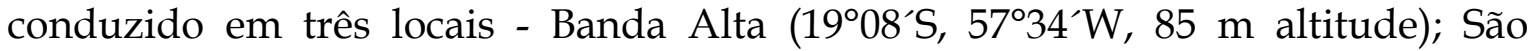

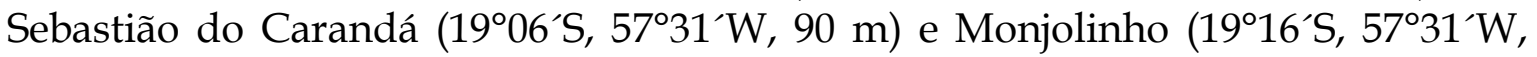
65-150 m). A vegetação encontrada nestes afloramentos rochosos ocorre como uma cobertura contínua sobre o substrato rochoso ou como ilhas de solo. Para o estrato contínuo, a vegetação foi amostrada em parcelas de $1 \mathrm{~m}^{2}$ distribuídas aleatoriamente. A própria ilha de solo foi considerada uma unidade amostral. A composição de espécies e os valores de cobertura foram avaliados em cada parcela ou ilha de solo. Avaliaram-se 199 parcelas e 164 ilhas de solo neste estudo. Além da abundância das espécies o tamanho e outras características das ilhas de solo foram incluídas neste levantamento. Os dados foram explorados através de tabelas fitossociológicas e de técnicas estatísticas de classificação e ordenação. As relações florísticas foram exploradas nos níveis taxonômicos de famílias e gêneros pela comparação de listas de espécies publicadas de outros afloramentos. Foram amostradas 188 espécies pertencentes a 58 famílias nas três bancadas lateríticas. Deste total, 66 espécies foram encontradas nas parcelas e 181 nas ilhas de solo. A estrutura da comunidade é influenciada, principalmente, pela presença de fina camada de substrato e pela área insular. Processos envolvendo competição exclusiva e diferentes respostas ao regime hídrico aparentemente podem ser as maiores fontes da separação espacial e padrões de abundância. A flora das bancadas lateríticas mostrou similaridade com a flora de afloramentos graníticos da Caatinga, em nível de famílias e gêneros. Condições climáticas e outros fatores podem influenciar as disjunções florísticas observadas mas o substrato rochoso parece ser o fator determinante, com exceção das bancadas lateríticas. Esperava-se que as bancadas fossem similares a outros afloramentos ferruginosos mas isto não ocorreu, sugerindo um importante efeito da história paleoclimática da plataforma continental nos padrões de composição e abundância de espécies da comunidade vegetal das bancadas lateríticas.

Palavras-chave: afloramento rochoso, canga, campo, florística, ecologia de comunidades 


\section{ABSTRACT}

The ironstone outcrops called bancadas lateríticas can be considered a peculiar feature of the Central Brazil landscape nearby the cities of Corumbá and Ladário (MS). Although situated in a populated region, near farmlands and cities, the vegetation occurring on these outcrops is completely unknown. In this work we aim to explore the species composition, the floristic relations with other rock outcrops and the community structure of the vegetation thriving on the ironstone surface of the bancadas. The survey was conducted in three outcrops - Banda Alta

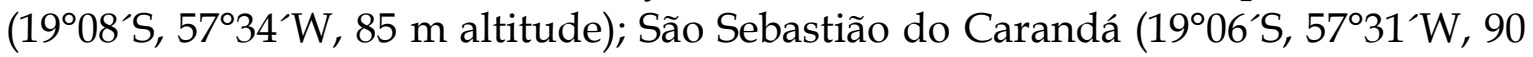
$\mathrm{m})$ and Monjolinho $\left(19^{\circ} 16^{\prime} \mathrm{S}, 57^{\circ} 31^{\prime} \mathrm{W}, 65-150 \mathrm{~m}\right)$. The vegetation found on the rock outcrops occurred as a continuous cover or in groups called soil-islands. In the continuous formation, the vegetation cover was sampled by random Quadrats of $1 \mathrm{~m}^{2}$. A single soil island was taken as a sample unit. The species composition and correspondent cover value was evaluated for each quadrat and soil island. A total of 199 random quadrats and 164 soil islands was used in this work. Along with the abundance of species, the size and other features of each soil islands were included in the survey. The data was explored by the construction of phytosociological tables and statistical classification and ordination techniques. The floristic relations were explored at the level of families and genera by comparisons with published species lists from other outcrops. We detected 188 species belonging to 58 plant families on the three Bancadas outcrops. From this total, 66 species were found in random quadrats and 181 in soil islands. The community structure is primarily influenced by the substrate thickness and the soil island area. Processes involving apparent species competitive exclusion and different responses to water regime can be major sources of the overall spatial disjunction and abundance patterns. The bancadas flora showed similarities with the flora of granite outcrops in the Caatinga formation at the level of genera and families. Climate and other factors can play a role in the floristic disjuntions observed but the rock substrate poses as a dominant factor with the exception of the Bancadas. The departure from the expected similarity with other ironstone outcrops suggests an important effect of Paleoclimatic history of the continental shelf in the patterns of species composition and abundance in the Bancadas plant community.

Keywords: rock outcrops, canga, grassland, floristic, community ecology 


\title{
Capítulo 1
}

\section{Composição florística e estrutura da vegetação sobre}

\author{
afloramentos rochosos ferruginosos
}

(bancadas lateríticas) em Corumbá e Ladário, MS

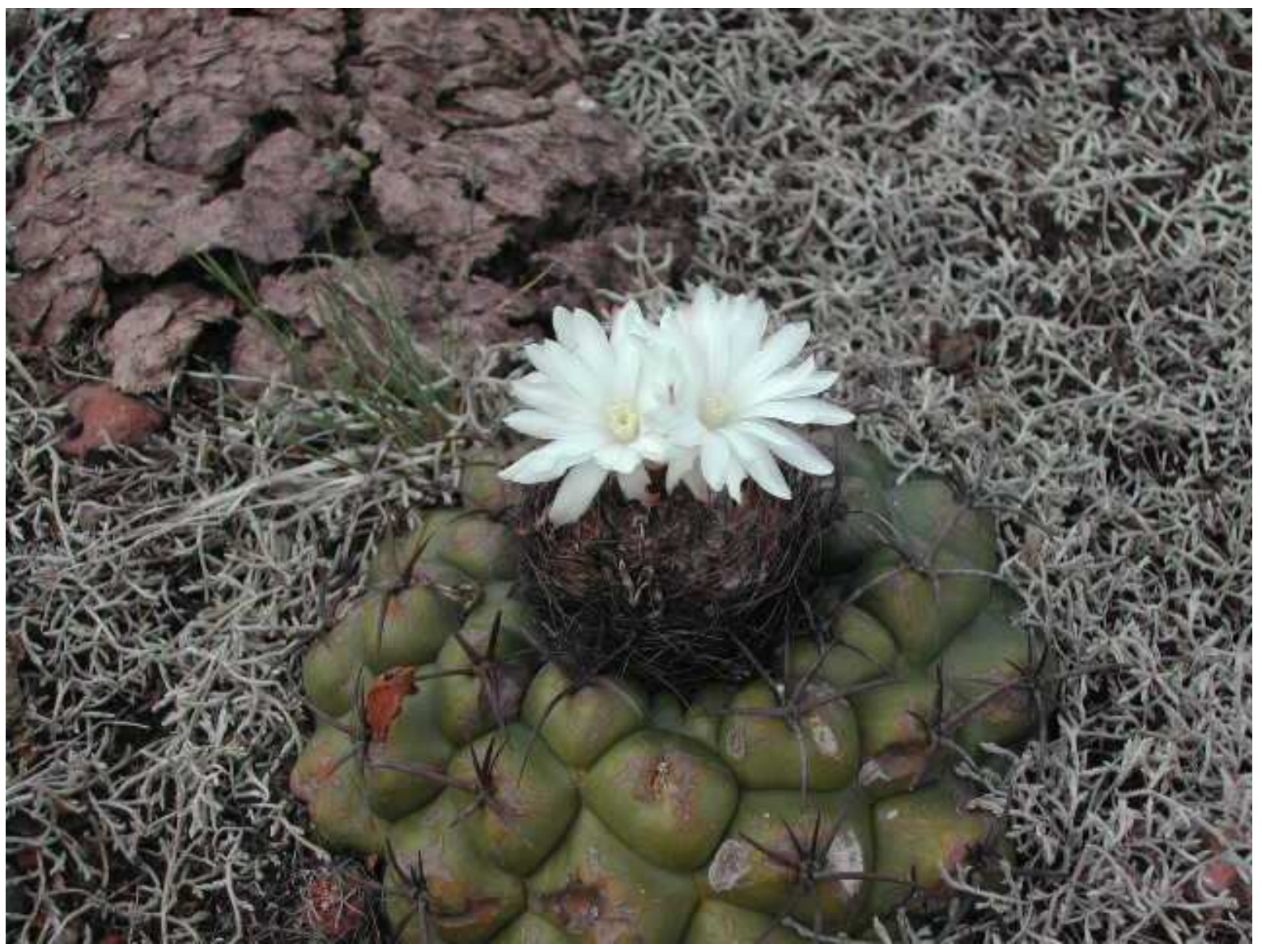

Discocactus ferricola Buining $\mathcal{E}$ Brederoo e Selaginella sellowii Hieron. na Fazenda Monjolinho, Corumbá, MS. 
Que maravilha:

Nas folhas verdes, nas folhas novas, Brilha o sol!

\section{Bashô}

(cc. Japão - 1644 - 1694)

(In: Haikai, Paulo Franchetti, org; Elza Taeko Doi, Luiz Dantas, Unicamp, 1991) 


\section{RESUMO}

Os afloramentos rochosos ferruginosos denominados bancadas lateríticas podem ser considerados uma paisagem peculiar no Centro-Oeste do Brasil, próximos às cidades de Corumbá e Ladário, MS. Embora situada em uma região populosa, próxima a fazendas e sítios urbanos, esta vegetação ainda é desconhecida. Neste estudo avaliamos a composição florística e a estrutura da comunidade, bem como a relação entre número de espécies e área insular. $\mathrm{O}$ levantamento foi conduzido em três locais - Banda Alta $\left(1^{\circ} 08^{\prime} \mathrm{S}, 5^{\circ} 34^{\prime} \mathrm{W}, 85 \mathrm{~m}\right.$ altitude); São Sebastião do

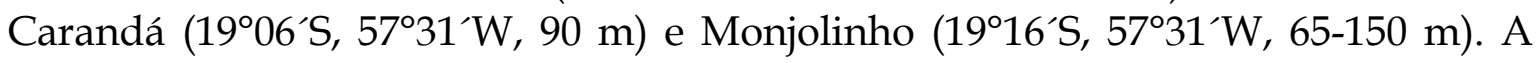
vegetação encontrada nestes afloramentos rochosos ocorre como uma cobertura contínua sobre o substrato rochoso ou como ilhas de solo. Para o estrato contínuo, a vegetação foi amostrada em parcelas de $1 \mathrm{~m}^{2}$ distribuídas aleatoriamente. A própria ilha de solo foi considerada uma unidade amostral. A composição de espécies e os valores de cobertura foram avaliados em cada parcela ou ilha de solo. Avaliaram-se 199 parcelas e 164 ilhas de solo neste estudo. Na Fazenda Banda Alta, o substrato foi classificado como seco ou encharcado antes da amostragem da vegetação. Além da abundância de espécies, consideramos a proporção de rocha exposta no interior das parcelas e o tamanho de cada ilha de solo. Os dados foram explorados através de parâmetros fitossociológicos e de técnicas estatísticas de classificação e ordenação. Foram executadas a análise de correspondência na modalidade DCA e a análise de coordenadas principais. Os escores resultantes dos procedimentos de ordenação foram usados para testar a segregação de grupos e a correlação com variáveis originais usando modelos lineares como ANOVA e regressão. A relação espécie-área para as ilhas de solo foi explorada usando modelos baseados nas funções logarítmica e potência. Amostraram-se 188 espécies pertencentes a 58 famílias em uma área total de $6405 \mathrm{~m}^{2}$. As três famílias mais ricas em espécies foram Fabaceae, Poaceae e Malvaceae. Apenas um quarto das espécies esteve presente em todos os sítios e quase $40 \%$ das espécies ocorreu em um único local, revelando um forte efeito local, apesar da pequena distância entre os afloramentos. A espessura do substrato parece ser o principal atributo afetando a composição de espécies, além do regime hídrico. Os habitats encharcado e seco da Fazenda Banda Alta revelaram uma segregação significativa. As ilhas de solo se diferenciaram, principalmente, pela espécie de bromélia dominante, Bromelia balansae e Deuterocohnia meziana. Além destas espécies, Selaginella sellowii também foi importante na diferenciação dos tipos de ilhas de solo. O melhor ajuste para a relação entre o número de espécies e a área insular foi dada pela função potência, encontrado em sistemas similares. A composição de espécies nas ilhas de solo aparentemente é afetada pela classe de tamanho, com um maior distinção entre ilhas pequenas, médias e grandes.

Palavras-chave - afloramentos rochosos, canga, campos ferruginosos, ilhas de vegetação, relação espécie-área 


\section{ABSTRACT}

The ironstone outcrops called bancadas lateríticas can be considered a peculiar feature of the Central Brazil landscape nearby the cities of Corumbá and Ladário (Ms). Although situated in a populated region, near farmlands and cities, the vegetation occurring on these outcrops is completely unknown. In this work we aim to explore the species composition, the community structure, and the speciesarea relation of soil-islands of the vegetation thriving on the ironstone surface of the Bancadas. The survey was conducted in 3 outcrops - Banda Alta $\left(19^{\circ} 08^{\prime} \mathrm{S}\right.$,

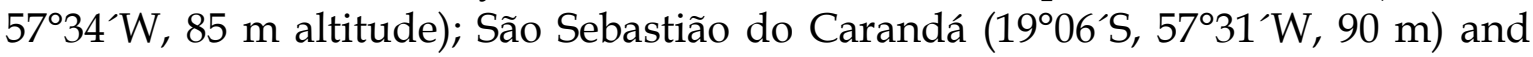
Monjolinho $\left(19^{\circ} 16^{\prime} \mathrm{S}, 5^{\circ} 31^{\prime} \mathrm{W}, 65-150 \mathrm{~m}\right)$. The vegetation found on the rock outcrops occurred as a continuous cover or in groups called soil-islands. In the continuous formation, the vegetation cover was sampled by random Quadrats of $1 \mathrm{~m}^{2}$. A single soil island was taken as a sample unit. The species composition and correspondent cover value was evaluated for each quadrat and soil island. This work included 199 random quadrats and 164 soil islands. In the Banda Alta site, the substrate was classified as dry or waterlogged prior to vegetation sampling. Along with the abundance of species, we considered the size of each soil island and the bald rock proportion of each Quadrat in the survey. The data was explored using phytosociological tables and ordination statistical methods. Detrended Correspondence Analysis and Principal Coordinate Analysis were used as exploratory methods. The resulting ordination scores were used to test for segregation of groups and correlation with original variables using linear models as ANOVA and regression. The species-area relation in the soil islands was explored using models based on log and power functions. A total of 188 species pertaining to 58 families was found in a total area of $6405 \mathrm{~m}^{2}$. The three richest families in number of species were Fabaceae, Poaceae and Malvaceae. Only onefourth of the total species occurred in all sites being almost $40 \%$ found in one outcrop, making apparent the strong local effect in spite of the small distance among the sites. Substrate thickness can be the main factor affecting species composition beside water regime. A significant segregation was found between waterlogged and dry habitats in the Banda Alta site. Soil islands differ primarily according to the dominating bromeliad species, Bromelia balansae and Deuterocohnia meziana. Selaginella sellowii followed in importance in differentiating the soil island types. The relation between number of species and island area was best fitted by the power function model, found in similar systems. Species composition in soil islands is apparently affected by size class, with a major distinction between small, medium and large islands.

Keywords: rock outcrop, canga, ferrugineous grassland, soil-island vegetation, species-area relation 


\section{Introdução}

Distribuídos por todo o globo, os afloramentos rochosos concentram-se em topos de morros e outras elevações. A vegetação que porventura se instala nestes ambientes encontra condições bastante inóspitas, como os altos níveis de insolação, a grande amplitude térmica, a ausência de solo e escassez de água, além da ação deletéria de ventos e enxurradas.

Esta comunidade vegetal não recebe uma denominação específica, sendo tratada, muitas vezes, como "vegetação sobre afloramentos rochosos", face a variedade de domínios florísticos na qual se encontra inserida. Entretanto, Rizzini (1997), ao tratar dos tipos de vegetação que ocorrem no Brasil, situou as plantas que se estabelecem em topos de morros no tipo campos limpos enfatizando sua ampla distribuição, desde as chapadas areníticas e quartzíticas no Centro-Oeste brasileiro, sobretudo em Goiás e Minas Gerais, até as serras dos estados sulinos, onde o clima é mais frio e sem estação seca. Este autor tratou os campos sobre as cangas como uma categoria dentro de campo limpo, definindo-os como "campos ferruginosos" e os subtipos "canga couraçada" e "canga nodular".

O termo "canga" é uma simplificação de "tapanhoacanga" palavra de origem tupi que significa "cabeça de negro" pela semelhança com as formas que as crostas ferruginosas lembravam as carapinhas dos escravos africanos que trabalhavam na mineração na região do Quadrilátero Ferrífero no início do século 19 (Castro 2008). Por extensão, este termo refere-se à rocha formada por material detrítico, com minerais ricos em ferro, moderadamente dura, bem consolidada, levemente permeável e muito resistente à erosão (Castro 2008). 
No Brasil, a vegetação sobre cangas foi abordada sob aspectos florísticos na Serra de Carajás, Pará, e nos campos rupestres de Minas Gerais. Consistiam na elaboração de "checklists" em localidades específicas, como a Serra do Curral em Belo Horizonte (Brandão 1992), a Serra da Piedade em Caeté (Grandi et al. 1988, Brandão \& Gavilanes 1990) e a Reserva Biológica Municipal do Poço Bonito em Lavras (Gavilanes \& Brandão 1991), bem como em levantamentos botânicos de locais a serem explorados por mineração na Serra Norte em Carajás (Secco \& Mesquita 1983, Silva 1991), assim como a caracterização dos tipos de vegetação sobre cangas (Cleef \& Silva 1994), além de aspectos sobre a ecologia destas comunidades vegetais (Secco \& Lobo 1988, Silva et al. 1996). Ressalta-se que em alguns destes trabalhos não é possível distinguir os habitats amostrados ou obter informações sobre características ambientais que influenciam o estabelecimento de plantas como solo, geologia, clima, declividade, ocorrência de fendas, fraturas, depressões, locais sazonalmente encharcados, etc. e qual o esforço amostral em cada um deles, dificultando comparações com outros estudos sobre a vegetação em afloramentos rochosos.

Nos últimos cinco anos a vegetação sobre cangas tem despertado a atenção de pesquisadores com a publicação de estudos sobre florística, fitossociologia e ecologia destas comunidades do Quadrilátero Ferrífero em Minas Gerais (Vincent 2004, Jacobi et al. 2007, Mourão \& Stehmann 2007, Viana \& Lombardi 2007, Jacobi et al. 2008, Vincent \& Meguro 2008) além de um único trabalho realizado na Floresta Nacional de Carajás (PA), região Amazônica (Rayol 2006). 
Como os estudos nestas comunidades ainda são recentes temos uma profusão de termos e nomes utilizados para definir ou caracterizar esta vegetação, como por exemplo: campo rupestre (Grandi et al. 1988, Secco \& Lobo 1988, Brandão 1992, Silva et al. 1996), campo rupestre ferruginoso (Vincent \& Meguro 2008), canga hematítica (Silva 1991, Cleef \& Silva 1994, Mourão \& Stehmann 2007) ou simplesmente canga (Secco \& Mesquita 1983, Vincent 2004, Jacobi et al. 2007, Viana \& Lombardi 2007, Jacobi et al. 2008), além de vegetação xerofítica de savanas metalófitas (Rayol 2006). Neste trabalho utilizamos o termo vegetação sobre afloramentos rochosos ferruginosos para destacar a importância deste atributo para o estabelecimento das comunidades vegetais estudadas.

O Quadrilátero Ferrífero (MG), a Serra de Carajás (PA) e as Morrarias Residuais do Urucum e Amolar (MS) possuem as maiores reservas de minério de ferro do país e, por sua vez, a vegetação associada tanto aos afloramentos rochosos quanto aos campos ferruginosos encontra-se ameaçada pela constante demanda mundial por este minério. O Estado de Mato Grosso do Sul possui a terceira maior reserva em minério de ferro do país ( $17 \%$ do total) (www.dnpm.gov.br) concentrada na região das Morrarias Residuais do Urucum e Amolar. Embora a legislação ambiental brasileira determine a recuperação de áreas degradadas por mineração o potencial da vegetação sobre cangas para este propósito ainda é pouco explorado (Jacobi et al. 2008).

A vegetação sobre afloramentos rochosos e campos ferruginosos de Corumbá e Ladário tem sido avaliada em estudos pontuais (Bortolotto et al. 1999, Pott et al. 2000) e levantamentos rápidos para elaboração de relatórios de impacto 
ambiental ou de planos de recuperação de áreas degradadas pelas mineradoras que atuam na região. Poucos estudos botânicos (Silva 2006, Silva \& Tozzi 2008) ou sobre a ecologia desta vegetação (Ragusa-Netto \& Silva 2007) foram realizados até o momento, sendo que o presente estudo é o primeiro levantamento fitossociológico realizado nos afloramentos rochosos ferruginosos de Corumbá, também denominados "bancadas lateríticas".

As características ambientais dos afloramentos rochosos impõem à vegetação condições extremas de suprimento de água, limitadas pelo baixo volume de solo e pela alta exposição, que condiciona temperaturas elevadas e rápida evaporação (Porembski et al. 1998). A pequena profundidade do solo também limita a possibilidade de ancoragem de plantas de maior porte à superfície, normalmente restritas a fendas e bordas do afloramento onde o solo é mais profundo, não sendo raro o desprendimento de conjuntos de plantas inteiros e deslizamentos da vegetação em encostas mais íngremes.

Assim, plantas com características morfológicas e/ou metabólicas que permitam reduzir o efeito deletério de temperaturas elevadas, altas taxas de insolação além do baixo teor de água disponível devem ter um melhor desempenho na colonização e estabelecimento nos afloramentos rochosos.

Os primeiros organismos a colonizar as rochas nuas são cianobactérias e líquens e, posteriormente, espécies de plantas poiquilohídricas ou suculentas se instalam em pequenas depressões, cavidades ou fissuras da rocha (Hambler 1964, Meirelles et al. 1999). Tanto líquens quanto plantas pioneiras constituiriam sítios favoráveis ao estabelecimento de plantas mais exigentes (Sarthou et al. 2009). 
Pequenas depressões preenchidas por sedimentos, materiais orgânicos e de decomposição da rocha matriz podem ser colonizadas por plantas vasculares e, ao aumentar progressivamente de tamanho, alteram-se floristicamente (Burbanck \& Platt 1964).

Os agrupamentos de plantas nas ilhas de solo propiciam o aumento do volume de substrato e redução da exposição do solo permitindo um tempo maior de conservação da água (Meirelles 1996, Conceição et al. 2007a). A formação concêntrica de solo, da periferia da ilha para o seu centro, e o aumento no teor de matéria orgânica em ilhas de solo em estágios sucessionais mais tardios melhora a capacidade de troca catiônica e eleva o pH (Shure \& Ragsdale 1977). A partir da melhoria das condições ambientais nas ilhas de solo a comunidade vegetal se altera até atingir o estágio com plantas perenes onde fatores dependentes de densidade, como a competição, passam a regular os estágios finais da sucessão nestas comunidades (Shure \& Ragsdale 1977). Entretanto estas comunidades não atingiriam o equilíbrio nas fases finais de sucessão (estágio "arbustivo") já que a instabilidade do substrato e condições de seca provocariam alta taxa de mortalidade de plantas lenhosas reconduzindo as comunidades aos estágios iniciais (Sarthou et al. 2009).

A estrutura e sucessão primária em ilhas de solo em afloramentos graníticognáissicos foram avaliadas nos EUA e na África (Burbanck \& Platt 1964, Hambler 1964, Shure \& Ragsdale 1977, Wyatt \& Fowler 1977, Phillips 1981, Houle 1990, Porembski et al. 1995). Porém poucos estudos foram conduzidos na América do 
Sul (Sarthou et al. 2009, Ibisch et al. 1995) incluindo o Brasil (Meirelles 1996, Conceição 2003).

Embora os estudos da vegetação em afloramentos rochosos no Brasil tenham se intensificado nos últimos anos poucos trabalhos abordam as comunidades em ilhas de solo destacando-se os estudos no Rio de Janeiro (Meirelles et al. 1999, Ribeiro \& Medina 2002, Ribeiro et al. 2007), em São Paulo (Meirelles 1996) bem como na Bahia (Conceição et al. 2007a).

Considerando-se que as ilhas de solo são circundadas pela superfície rochosa exposta, onde as condições ambientais para o estabelecimento das espéciess são muito restritivas podemos considerá-las sistemas insulares terrestres ideais para se aplicar o conceito de biogeografia de ilhas.

De modo geral, a teoria de biogeografia de ilhas pressupõe que o número de espécies presentes em dada ilha diminui com a distância da fonte de propágulos sendo resultante do equilíbrio entre as espécies colonizadoras e as extintas em função da área (MacArthur \& Wilson 1963). Os fenômenos de imigração e extinção seriam independentes e opostos, onde a imigração seria afetada apenas pelo grau de isolamento da ilha enquanto a extinção seria afetada somente pela área.

A teoria de equilíbrio tem recebido diversas contribuições e críticas ao longo das últimas décadas como a incorporação de variáveis aos modelos de curvas espécie-área e hipóteses alternativas. Pode-se citar, por exemplo, a hipótese do efeito de ilhas pequenas ("small island effect"), aplicada principalmente para ilhas oceânicas, que pressupõe que certas espécies não ocorram em ilhas menores 
do que determinado tamanho (Whittaker 1998). A introdução de parâmetros nas curvas espécie-área que contemplem o efeito de ilhas pequenas onde a riqueza varia independentemente da área da ilha também tem sido proposta (Lomolino \& Weiser 2001). Vários estudos têm demonstrado que as premissas da teoria de equilíbrio, quais sejam, espécies e ilhas essencialmente idênticas, processos de imigração e extinção independentes e o equilíbrio dinâmico entre taxas de imigração e extinção, não são coerentes com dados empíricos (Brown \& Lomolino 2000). Estes autores sustentam que a principal falha nesta teoria é a hipótese de equilíbrio entre as taxas atuais de imigração e extinção já que a evolução e a diversidade de padrões nas assembléias de comunidades derivam de interações complexas de processos operando em escalas temporais e espaciais amplas (Brown \& Lomolino 2000). Estes autores destacam a importância das diferenças entre as espécies na determinação das assembléias das biotas insulares e que os processos de imigração e extinção são determinantes mas não estão necessariamente em equilíbrio (Brown \& Lomolino 2000).

A hipótese de heterogeneidade de habitats (Williams 1943) assume uma correlação entre área e número de habitats diferentes pois cada habitat está associado a um grupo diferente de espécies. Assim, o aumento da área permite que novos habitats sejam incluídos e outros grupos de espécies são encontrados. Entretanto, Kallimanis et al. (2008) sustentam que a área per se e a heterogeneidade ambiental são variáveis correlacionadas e que ambas tem um efeito significativo na riqueza de espécies de maneira independente e assim, estas duas hipóteses não devem ser tomadas como mutuamente exclusivas. Deste 
modo, a variedade de habitats não afeta diretamente a riqueza de espécies e sim a reposição das espécies no espaço e, neste caso, a escala utilizada pelo estudo determina a diversidade de habitas (Kallimanis et al. 2008).

A hipótese de amostragem passiva proposta por Coleman et al. (1982) prevê que se os indivíduos distribuem-se aleatoriamente em dado local amostras maiores conterão maior número de indivíduos e pode ser considerada uma hipótese alternativa às duas anteriores (Connor \& McCoy 1979) e, consequentemente, maior número de espécies.

O objetivo geral deste estudo foi caracterizar a vegetação que se estabelece sobre os afloramentos rochosos ferruginosos, as "bancadas lateríticas", na região de Corumbá e Ladário, MS, respondendo às seguintes questões:

- Qual é a composição florística e a estrutura da vegetação sobre afloramentos rochosos ferríferos na região de Corumbá, MS?

- Qual o grau de similaridade florística entre as diferentes bancadas lateríticas?

- Existe diferenças florística e estrutural na forma de ocupação da vegetação em ilhas de solo e sobre a superfície rochosa?

- Como esta vegetação se organiza ao longo do gradiente ambiental dos afloramentos rochosos ferruginosos de Corumbá?

- A composição e a cobertura das espécies variam em função do tamanho da ilha?

- Qual a relação entre a riqueza de espécies e o tamanho insular das ilhas de solo? 


\section{Material e Métodos}

\section{Área de estudo}

Este trabalho foi conduzido nas áreas de afloramentos rochosos ferruginosos conhecidos como "bancadas lateríticas" nas áreas de drenagem (em torno de 100 m de altitude) da Morraria do Urucum e do Rabicho, municípios de Corumbá e Ladário, MS. As “bancadas lateríticas” são consideradas não um tipo de solo, mas um tipo de relevo plano ou quase plano, formadas por camada de material laterítico endurecido, de natureza ferrífera (Cardoso et al. 2000), com pouca vocação para usos agrícolas ou pastoris (Pott et al. 2000). Essas áreas com superfície rochosa ferrífera exposta possuem, em seu interior, depressões, fendas ou cavidades com pequeno acúmulo de sedimentos, sobre os quais se estabelece uma vegetação predominantemente herbáceo-arbustiva. Ao redor destes lajedos encontram-se matas estacionais em diferentes níveis de degradação ou pastagens.

A região do Maciço do Urucum, na área estudada, está assentada sobre o embasamento Gnáissico-Granítico com Grupo Cuiabá e o Grupo Jacadigo na sequência (Haralyi \& Walde 1986, Anjos \& Okida 2000). Este último é constituído pela Formação Urucum (conglomerados com granitos, gnaisses, calcários e micaxistos) e pela Formação Santa Cruz (camadas de arcóseos com nódulos de criptomelano e criptomelano compacto, ricos em manganês e hematita), explorada comercialmente na região para extração de ferro e manganês. De modo geral, toda superfície onde está a vegetação é formada pela cobertura dendrítico-laterítica 
pleistocênica composta por sedimentos conglomeráticos e depósitos de talus com predominância de minérios de ferro. Nas áreas de planície essa cobertura forma uma carapaça (bancada) laterítica que se situa, em geral, na base dos solos de toda área de influência da sedimentação dos morros, aflorando nas áreas de linha de drenagem das águas (Brasil 1982, Haralyi \& Walde 1986, Anjos \& Okida 2000).

O clima de Corumbá é do tipo Awa segundo a classificação de Koppen correspondendo a um clima tropical megatérmico (a temperatura do mês mais frio é superior a $18{ }^{\circ} \mathrm{C}$ ) com inverno seco e chuvas no verão (Soriano 2000). A precipitação anual de Corumbá para o período de 1976 a 1996 foi de 1070 mm anuais com o período mais chuvoso de novembro a março, com $68 \%$ das chuvas e o mais seco de junho a agosto, com $7 \%$. A temperatura média anual foi $25,1{ }^{\circ} \mathrm{C}$, oscilando entre 21,4 e $27,7^{\circ} \mathrm{C}$. A média das máximas foi $30,6{ }^{\circ} \mathrm{C}$, atingindo máximas absolutas de $40^{\circ} \mathrm{C}$ entre outubro e janeiro. Já a média das mínimas foi de $21{ }^{\circ} \mathrm{C}$ atingindo mínimas absolutas próximas de $0{ }^{\circ} \mathrm{C}$. A umidade relativa média anual foi de $76,8 \%$, oscilando entre $71,8 \%$ e $80,9 \%$ (Soriano 2000 ).

Os trabalhos de campo desenvolveram-se com periodicidade mensal de novembro de 2005 a abril de 2007 e, bimestralmente daí em diante, até janeiro de 2009 em duas fazendas localizadas no município de Ladário e em uma fazenda no município de Corumbá, MS.

As fazendas visitadas em Ladário foram a "Banda Alta" (1908`S, 57³4’W, 85 m) e a "São Sebastião do Carandá" (1906’S, 57³1’W, 90 m), distantes cerca de 20 e 25 quilômetros respectivamente do campus da UFMS em Corumbá e acessadas por terra apenas pela Rodovia MS-228, tornada Área Especial de Interesse 
Turístico (Decreto Estadual n. 7122, de 17 março de 1993) pelo Governo do Estado de Mato Grosso do Sul, com a denominação "Estrada Parque Pantanal".

Já o único estabelecimento rural visitado no município de Corumbá foi a fazenda “Monjolinho" (19¹6’S, 57³1’W, 65-150 m), distante aproximadamente 50 quilômetros do campus da UFMS cujo acesso foi feito via de regra através da rodovia federal BR-262 (Figura 1).

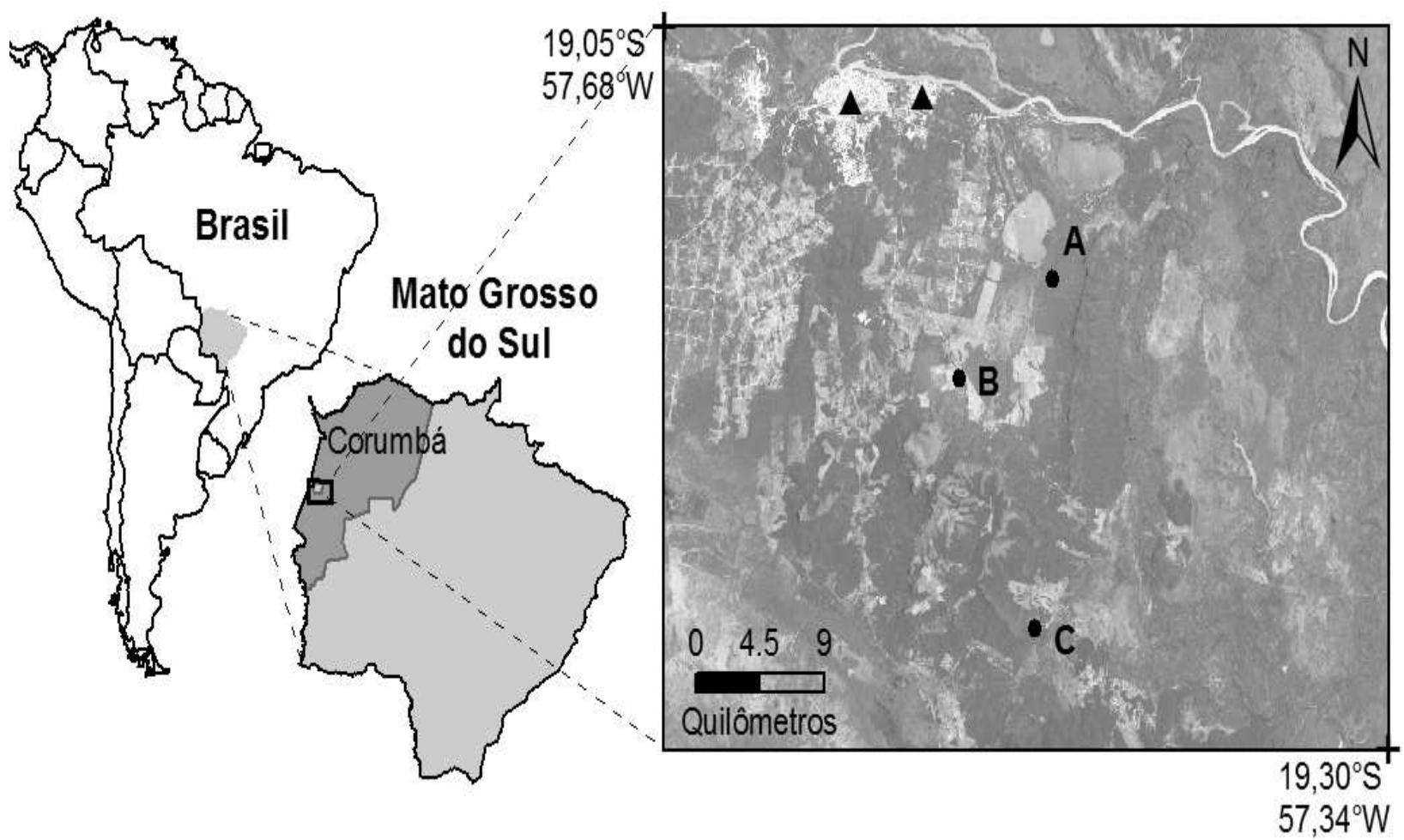

Figura 1 - Localização do Estado de Mato Grosso do Sul, do município de Corumbá, MS e das três áreas de estudo. No detalhe observam-se os sítios urbanos das cidades de Corumbá e Ladário (triângulos) e as três áreas de estudo localizadas no sopé da Morraria do Urucum: A=Fazenda São Sebastião do Carandá, B=Fazenda Banda Alta e C=Fazenda Monjolinho. Fonte: INPE, imagem do satélite Landsat 5 TM, de 1 de novembro de 2009, composição colorida RGB321. Elaborado por: Leandro Tambosi. 


\section{Delimitação da amostragem}

Foram definidos dois tipos de ocupação da vegetação dos afloramentos rochosos ferruginosos: a) plantas vasculares que se estabelecem diretamente sobre a superfície rochosa formando um estrato contínuo sem distinção de agrupamentos delimitados pela superfície rochosa e b) a vegetação que se agrupada nas ilhas de solo (Burbanck \& Platt 1964, Ibisch et al. 1995, Meirelles et al. 1999, Conceição \& Pirani 2005, Medina et al. 2006) (Figura 2). Este trabalho não amostrou cianobactérias, líquens ou briófitas que se estabelecem sobre a rocha.

A vegetação do estrato herbáceo foi avaliada em 199 parcelas de 1 x 1 m, distribuídas aleatoriamente no interior nas bancadas lateríticas, sendo 81 parcelas na Fazenda Banda Alta, 60 na Fazenda São Sebastião do Carandá e 58 na Fazenda Monjolinho. Os afloramentos rochosos das Fazendas São Sebastião do Carandá e Monjolinho apresentaram um estrato herbáceo distribuído de forma relativamente contínua sobre a superfície rochosa sendo interrompido apenas pela ocorrência de ilhas de solo. Na Fazenda Banda Alta foram definidos dois tipos de habitats em função da heterogeneidade da superfície rochosa: habitat 'seco' e habitat 'encharcado'. A porção do afloramento com uma superfície rochosa relativamente lisa, com alguns canais de drenagem e pequenas depressões, foi denominada habitat 'seco' e constitui a maior parte do afloramento. Já o 'habitat encharcado' localiza-se paralelamente ao Córrego Banda Alta e caracteriza-se por uma superfície da rocha apresenta-se bastante rugosa permitindo certo acúmulo de substrato permitindo que a água fique retida e escorra lentamente após cessarem as chuvas propiciando, assim, o estabelecimento de plantas efêmeras e típicas de 
ambientes sazonalmente inundáveis. Para verificar se a cobertura e composição de espécies foram estatisticamente diferentes nestes dois habitats foi empregada uma análise de variância com a matriz de dados padronizados para as espécies com mais de três ocorrências.

A vegetação que se agrega nas ilhas de solo pode ser descrita como a associação de duas ou mais espécies de plantas vasculares em uma área delimitada pelo substrato rochoso (Meirelles et al. 1999, Conceição et al. 2007a). As ilhas de solo foram consideradas unidades naturais com tamanho e formatos variados. Em campo todas as ilhas de vegetação foram medidas para posterior cálculo da área, numeradas e marcadas. Para determinação da área da ilha considerou-se que o formato predominante das ilhas de vegetação era aproximadamente uma elipse e utilizou-se a fórmula: $A=\left[\left(d_{1} / 2, d_{2} / 2\right) . \pi\right]$, onde A=área, $\mathrm{d}_{1}=$ distância maior, $\mathrm{d}_{2}=$ distância menor. Após o cálculo da área de cada ilha elas foram enquadradas em sete classes de tamanho procedendo-se ao sorteio de 10 ilhas por classe para a obtenção dos parâmetros fitossociológicos. Foram avaliadas as espécies vasculares presentes em 164 ilhas de vegetação, sendo 70 na Fazenda Banda Alta, 28 na Fazenda São Sebastião do Carandá e 66 na Fazenda Monjolinho. Ressalta-se que o baixo número de unidades insulares amostradas na Fazenda São Sebastião do Carandá ocorreu pela presença de poucas ilhas de solo neste local. 
A

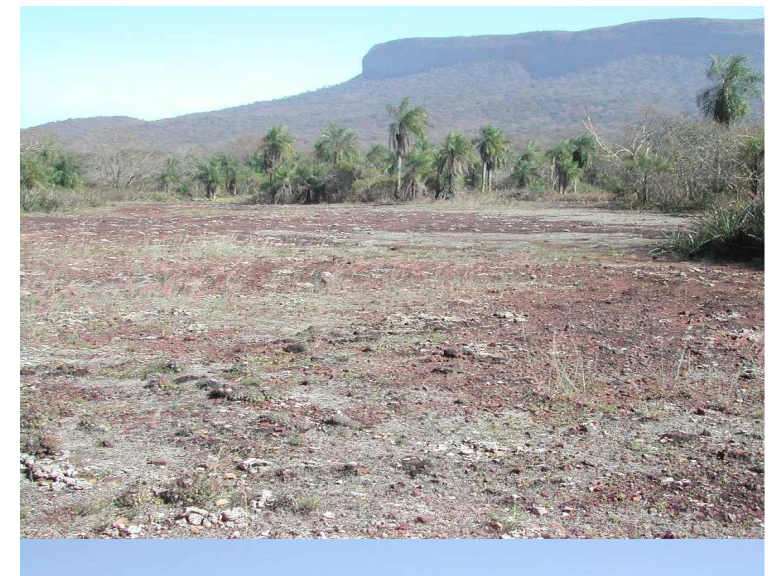

C

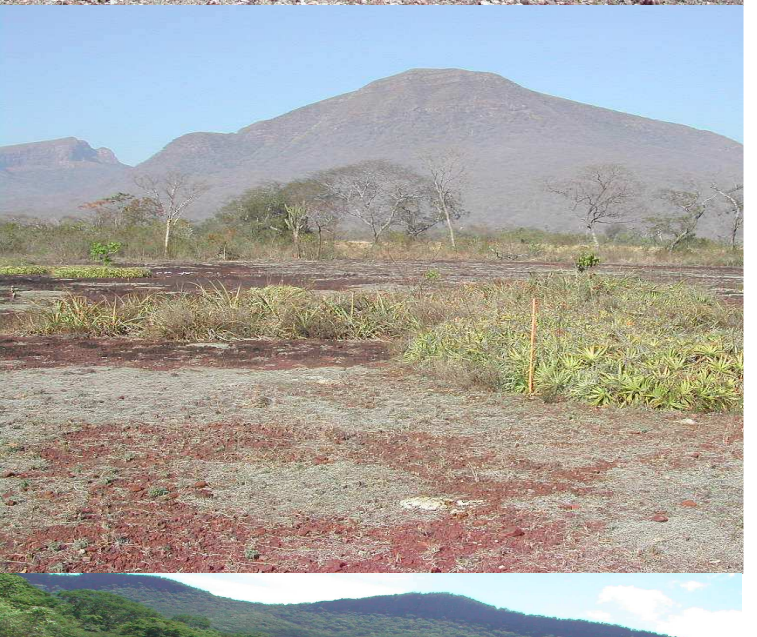

$\mathrm{E}$

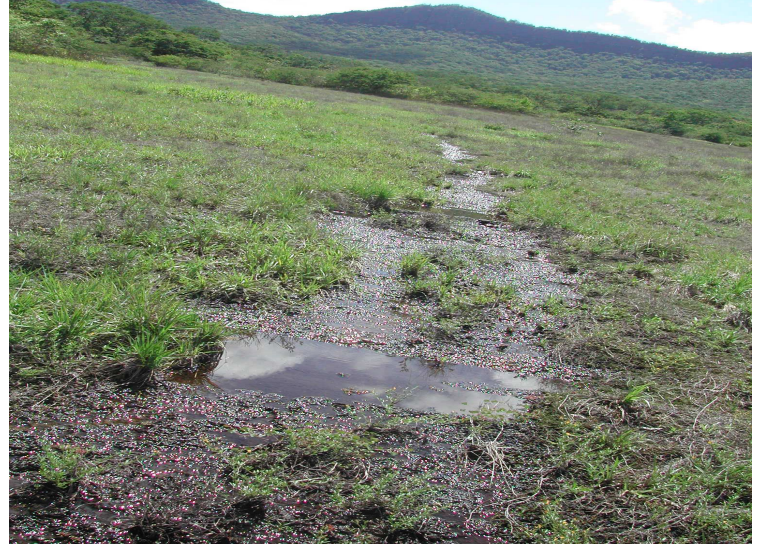

B

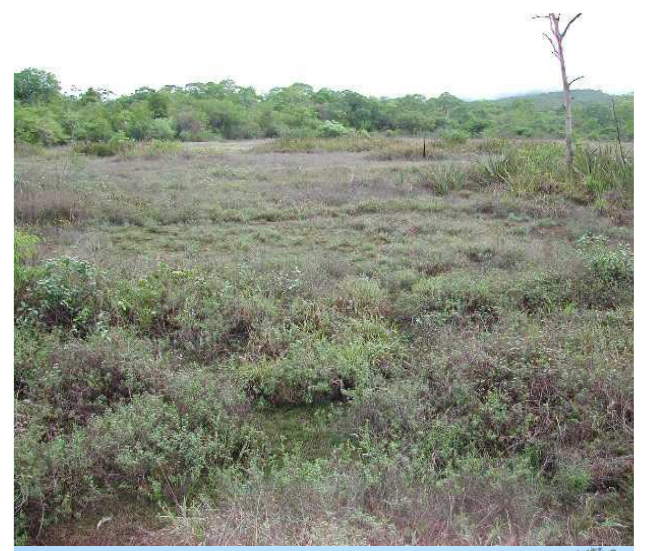

D

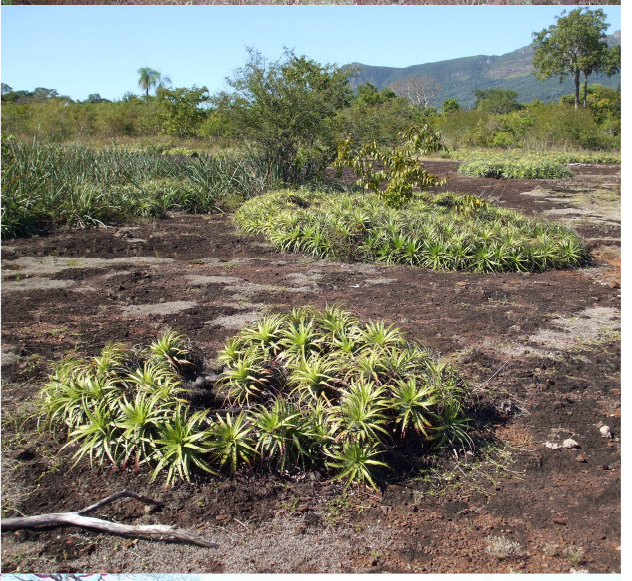

F

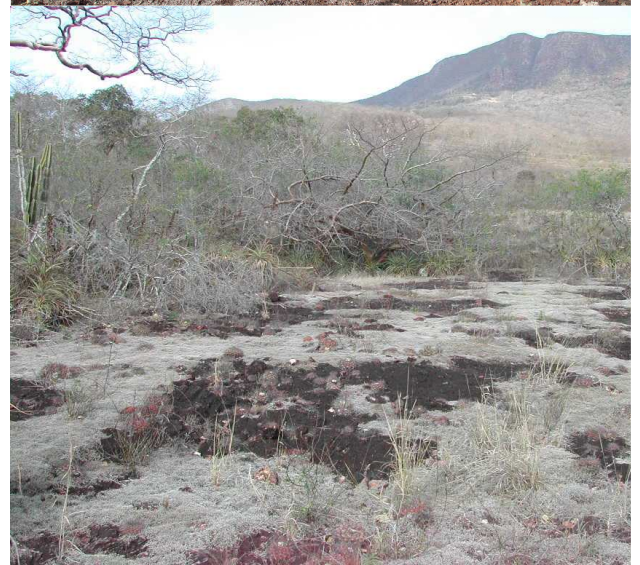

Figura 2 - Aspecto geral da vegetação nos afloramentos rochosos ferruginosos em Corumbá e Ladário, MS. A) estrato herbáceo das cangas da Fazenda Figueira, ao fundo algumas ilhas de solo com Acrocomia aculeata e, em último plano, a Morraria do Urucum, B) outro aspecto do estrato herbáceo na Fazenda S.S.Carandá, C) ilhas de solo com Bromelia balansae, D) ilhas de solo com Deuterocohnia meziana, E) aspecto da vegetação durante a estação chuvosa, F) e durante a estação seca. Fotos: Adriana Takahasi. 


\section{Coleta de dados}

Em cada unidade amostral (ilha de solo ou parcela) foram registradas as espécies vasculares presentes e estimou-se a cobertura vegetal considerando-se tanto as partes secas quanto as partes verdes das plantas. A cobertura vegetal foi definida como a projeção vertical da área ocupada por ramos ou copa de um indivíduo na superfície do solo expressa como fração ou porcentagem desta área (Mueller-Dombois \& Ellenberg 1974). Considerou-se que a cobertura da vegetação representa uma medida mais acurada da biomassa do que o número de indivíduos quando se trata de comunidades herbáceo-arbustivas. Para a análise fitossociológica, a estimativa de cobertura vegetal e a ocorrência de espécies foram tomadas durante o período chuvoso em função da máxima expressão nos valores de cobertura além de registro de espécies efêmeras que ocorrem somente durante o período mais úmido. Além das espécies vasculares foram estimadas a cobertura da superfície rochosa exposta, de pedras soltas ou de solo exposto sem plantas no interior das parcelas de $1 \times 1 \mathrm{~m}$.

\section{Parâmetros fitossociológicos}

Os parâmetros fitossociológicos utilizados para caracterizar a estrutura da vegetação foram frequência e dominância (cobertura), absolutas e relativas, e o valor de importância das espécies (Mueller-Dombois \& Ellenberg 1974). Os valores de frequência foram obtidos a partir do número de unidades amostrais (ilhas de vegetação ou parcelas) em que a espécie estava presente e os valores de 
dominância foram obtidos a partir do grau de cobertura estimado pela proporção da área da unidade amostral ocupada pela espécie em cada parcela ou ilha de solo. Como muitas espécies de plantas que se estabelecem sobre os afloramentos crescem em tufos ou apresentam-se rastejantes tornando difícil a distinção de indivíduos, a densidade de espécies não foi determinada. Assim, o índice de valor de importância (Mueller-Dombois \& Ellenberg 1974) foi modificado e tido como a soma da freqüência e dominância relativas, procedimento adotado em alguns estudos fitossociológicos do estrato herbáceo, como por exemplo, o estudo de Caiafa \& Silva (2007) em afloramentos rochosos em campos de altitude.

A diversidade específica da comunidade sobre afloramentos rochosos foi expressa através do índice de diversidade de Shannon $\left(\mathrm{H}^{\prime}\right)$ na base logarítmica natural com uma modificação utilizando-se, ao invés de número de indivíduos, os valores de cobertura amostrados. A equabilidade de Pielou (J) também foi calculada para as localidades (Krebs 1989).

O material testemunho foi depositado no Herbário COR (UFMS, campus do Pantanal, Corumbá, MS) com duplicatas aos especialistas que identificaram o material: Adriana Guglieri (Poaceae, UFMS), Ana Maria Goulart de Azevedo Tozzi (Leguminosae, UNICAMP), Cintia Kameyama (Acanthaceae, Instituto de Botânica São Paulo), Claudia Elena Carneiro (Caryophyllaceae, UEFS), Elton M. Assis (Ophioglossaceae, Polypodiaceae, Pteridaceae, Schizaeaceae, Selaginellaceae, UFMS), Gerleni Lopes (Malvaceae s.l. , Instituto de Botânica São Paulo), Juliana Lovo (Iridaceae, USP), Kikyo Yamamoto (Ochnaceae, UNICAMP), Luiza S. Kinoshita (Apocynaceae, UNICAMP), Marcela Firens (Rubiaceae, UNICAMP), 
Marcos José da Silva (Euphorbiaceae, Phyllanthaceae, UNICAMP), Maria Ana Farinaccio (Asclepioideae, USP), Maria Candida Mamede (Malpighiaceae, Instituto de Botânica São Paulo), Maria do Carmo Amaral (Commelinaceae, UNICAMP), Osny Tadeu Aguiar (Myrtaceae, Instituto Florestal de São Paulo), Rafael Trevisan (Cyperaceae, UFRGS), Renata Oliveira (Amaryllidaceae, UNICAMP), Renata Sebastiani (Malpighiaceae-Janusia, Instituto de Botânica São Paulo), Rosangela Simão Bianchini (Convolvulaceae, Instituto de Botânica São Paulo), Roseli Torres (Cannabaceae, Salicaceae, IAC-Campinas), Rosilene Silva (Leguminosae, UNICAMP), Rubens T. Queiroz (Leguminosae, UNICAMP) e Washington Marcondes Ferreira (Apocynaceae-Aspidosperma, Combretaceae, UNICAMP). A circunscrição de famílias baseou-se em APG II (APG 2003) e o nome dos autores de espécies foi verificado em Brummitt \& Powell (1992).

Fisionomia: formas de vida e desenhos esquemáticos da vegetação

Cada espécie amostrada foi classificada segundo a forma de vida utilizando-se a proposta de Raunkiaer: suculentas, epífitas, fanerófitas (subdivididas em nanofanerófitas e microfanerófitas), caméfitas, hemicriptófitas, criptófitas (geófitas), terófitas, acrescentando-se a categoria lianas (Raunkiaer 1934).

Foram elaborados dois desenhos esquemáticos da vegetação em perfil, correspondente a um trecho de $2 \times 10 \mathrm{~m}$ na Fazenda Banda Alta. O primeiro representou a vegetação do estrato herbáceo e o segundo a vegetação em ilhas de solo. 


\section{Suficiência amostral}

A representatividade do esforço amostral foi verificada através da construção de curvas de número acumulativo de espécies ou curvas de rarefação (Colwell \& Coddington 1994) com intervalos de confiança de 95\% para a cobertura vegetal das espécies registradas nas parcelas de 1 x 1m e nas ilhas de solo em cada localidade através do procedimento de bootstrap com auxílio do Programa Past: Paleontological Statistics software package for education and data analysis, versão $1.94 b$.

\section{Análises de ordenação}

As relações entre a cobertura vegetal e a composição de espécies em parcelas de $1 \times 1 \mathrm{~m}$ e em ilhas de solo nos diferentes locais foram exploradas através da análise de coordenadas principais (PCO) empregando-se o coeficiente de distância de Gower e da análise de correspondência na modalidade DCA empregando-se o algoritmo de Hill com a correção de tendência ("detrending”) empregando-se a partição em 26 segmentos para recálculo com 100 iterações (Legendre \& Legendre 1998). Para tanto, a matriz contendo valores de cobertura de espécies por parcela ou ilha de solo foi reduzida considerando-se apenas aquelas espécies com três ocorrências ou mais. Em seguida, a matriz foi padronizada por valor máximo no espaço das variáveis. Para explorar como a composição de espécies e cobertura em função do gradiente de vegetação em parcelas assim como nas ilhas de solo nas bancadas lateríticas foram conduzidas 
correlações de Pearson entre as espécies presentes nas unidades amostrais e os escores dos primeiros eixos resultantes da PCO.

As análises de ordenação (PCO e DCA) foram realizadas com auxílio do programa MVSP for Windows versão 3.1 (Kovach Computing Services) enquanto as correlações de Pearson foram executadas com o programa SPSS for Windows versão 13.0 .

\section{Composição e cobertura de espécies em função do tamanho insular}

As relações entre a abundância e composição de espécies em função do tamanho insular foram exploradas através de uma análise de correspondência na modalidade DCA empregando-se o algoritmo de Hill (Legendre \& Legendre 1998). Foram empregadas as matrizes com os valores de cobertura de espécies por ilha de solo em cada localidade padronizadas por valor máximo no espaço das variáveis retirando-se as espécies com uma única ocorrência. A associação entre os gradientes descritos pelos dois primeiros eixos resultantes do DCA e a área insular foi explorada a partir do agrupamento das unidades insulares em classes de tamanho. Foram construídos gráficos do tipo "Box-plot" representando a mediana, o intervalo de confiança de $95 \%$ e a amplitude dos escores correspondentes às classes de tamanho e os escores aos dois primeiros eixos, verificando-se a relação entre a composição e cobertura das espécies e a classe de tamanho insular. Se observada esta relação, executou-se uma análise de variância com testes de comparações múltiplas a posteriori de Tuckey (Zar 1974) para constatar quais médias foram significativamente distintas. Além disso, os escores 
obtidos por cada classe de tamanho foram comparados utilizando-se um modelo linear.

A análise de ordenação na modalidade DCA foi realizada com auxílio do programa MVSP for Windows versão 3.1 (Kovach Computing Services) enquanto as análises de variância, teste de Tuckey e gráficos do tipo "Box-plot" foram executados com o programa SPSS for Windows versão 13.0.

\section{Riqueza versus área insular}

A relação entre riqueza específica e a área insular foi verificada através da aplicação de modelos de regressão não lineares entre o número total de espécies amostradas em cada unidade insular e a área em metros quadrados para cada sítio, conforme vem sendo proposto por diversos autores (Arrhenius 1921, Gleason 1922, MacArthur \& Wilson 1967, Connor \& McCoy 1979, Gilbert 1980). Os modelos aplicados foram as funções potência, logarítmica e exponencial, levandose em conta o conjunto total de ilhas e o conjunto pertencente a cada sítio separadamente, com auxílio do programa SPSS for Windows versão 13.0 


\section{Resultados}

\section{Composição florística das bancadas lateríticas}

Foram registradas 188 espécies de plantas vasculares pertencentes a 58 famílias botânicas, além de dois táxons não identificados, em uma área total amostrada de $6405 \mathrm{~m}^{2}$ (parcelas de $1 \times 1 \mathrm{~m}$ e ilhas de solo) em afloramentos rochosos ferruginosos de Corumbá, MS (Anexo 1 e Figura 3). Deste total, foram contabilizadas oito espécies de pteridófitas pertencentes a cinco famílias. As cinco famílias com maior número de espécies representaram 37\% do total de espécies amostradas: Fabaceae (20 espécies), Poaceae (19), Malvaceae (13), Euphorbiaceae (9) e Cyperaceae (8) (Figura 4).

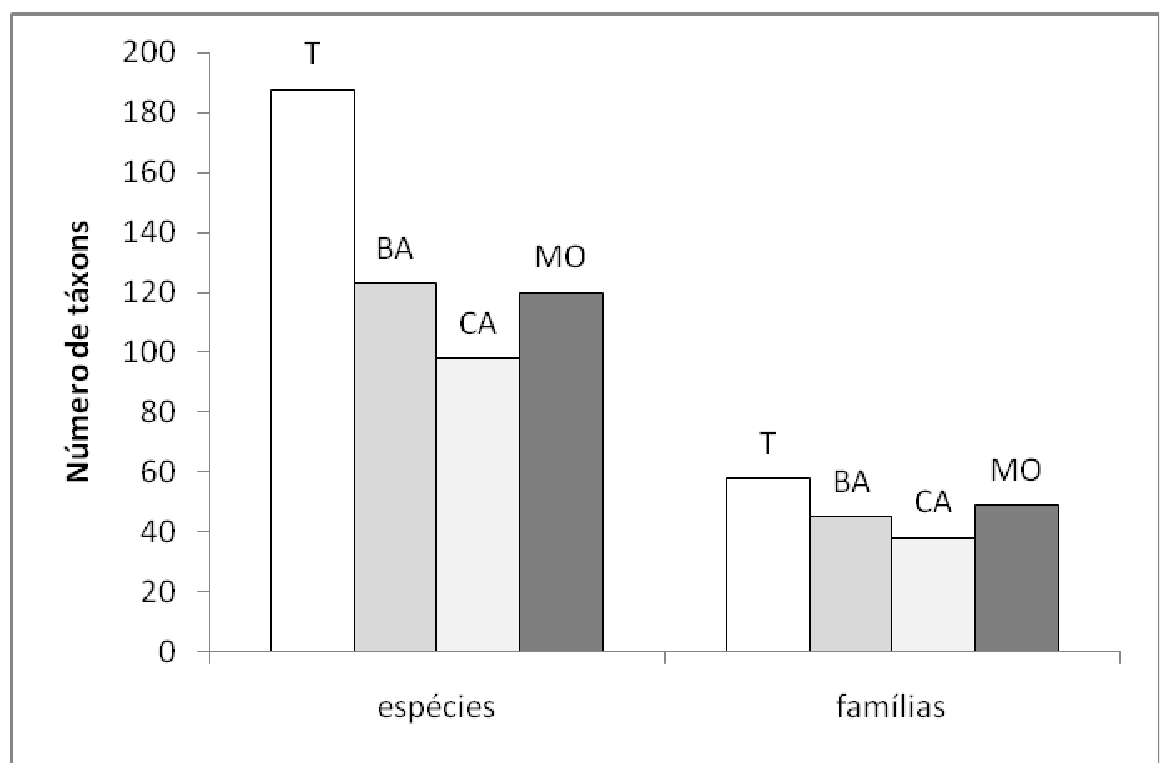

Figura 3 - Número total de espécies e de famílias botânicas amostradas nos afloramentos rochosos ferruginosos de Corumbá, MS e em cada localidade. T=total, BA=Fazenda Banda Alta, CA= Fazenda São Sebastião do Carandá e MO= Fazenda Monjolinho. 


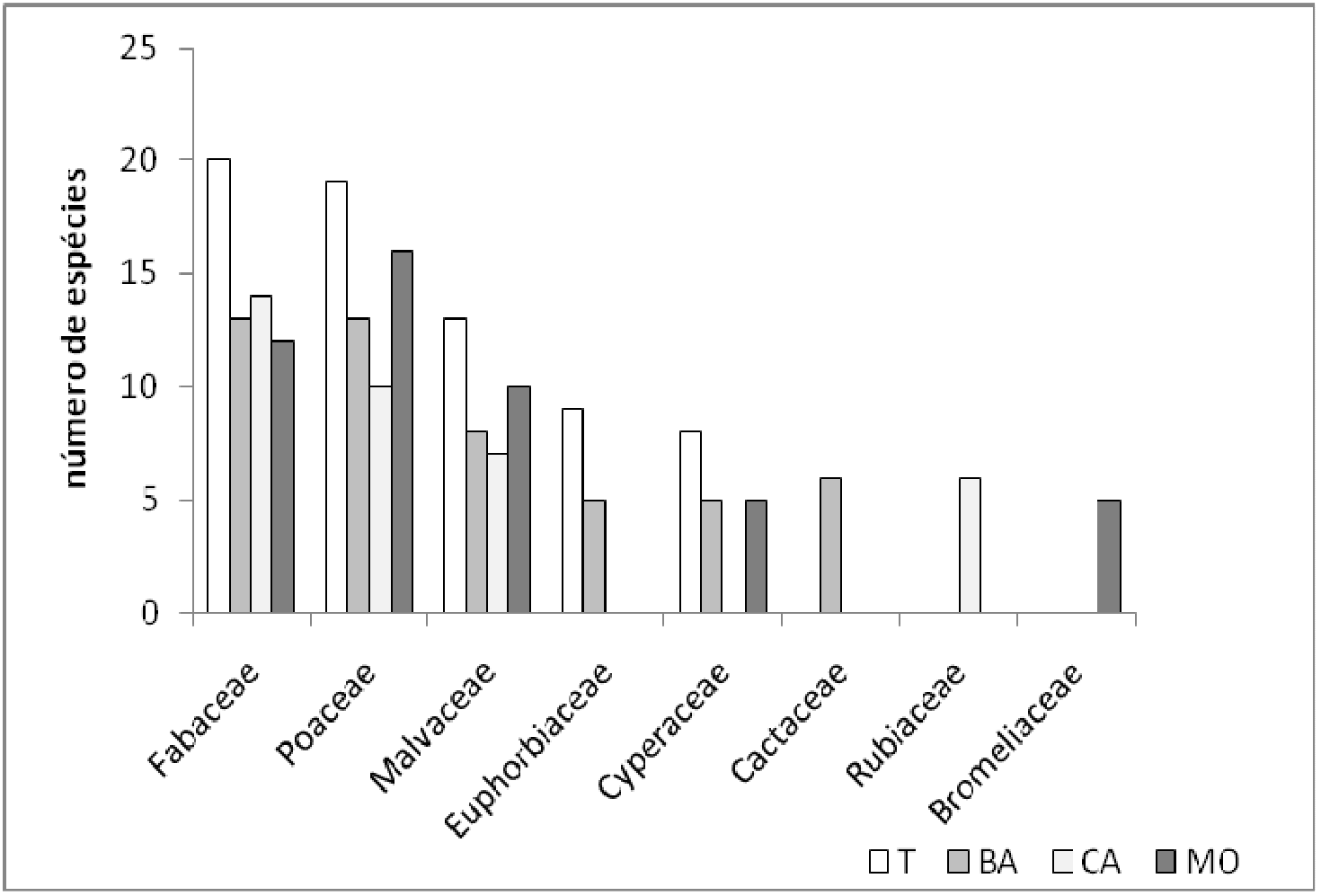

Figura 4 - As cinco famílias mais ricas em número de espécies amostradas nos afloramentos rochosos ferruginosos de Corumbá, MS, e em cada localidade. T=total, BA=Fazenda Banda Alta, CA= Fazenda São Sebastião do Carandá e MO= Fazenda Monjolinho.

Quando se compararam os sítios estudados verificou-se que o local com a maior área de afloramento rochoso amostrada foi a Fazenda S.S. Carandá (2860 $\mathrm{m}^{2}$ ), porém foi o que registrou a menor riqueza específica (95) e de famílias botânicas (38) (Figuras 3, 4 e 5). Por outro lado, as Fazendas Banda Alta (2211 m²) e Monjolinho $\left(1334 \mathrm{~m}^{2}\right)$ apresentaram números semelhantes de espécies e de famílias amostradas (116/43 e 119/49, respectivamente) (Figuras 3, 4 e 5). 


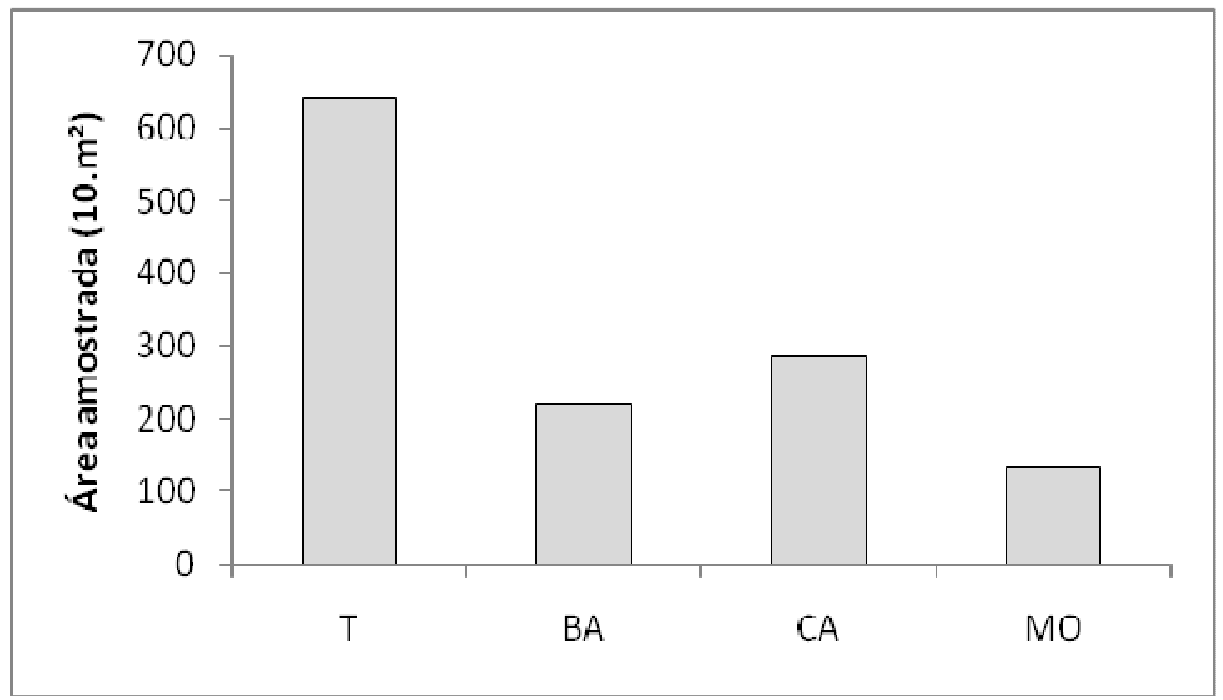

Figura 5 - Área total amostrada em 164 ilhas de solo e 199 parcelas de $1 \times 1 \mathrm{~m}$ nos afloramentos rochosos ferruginosos de Corumbá, MS e em cada localidade. T=total, BA=Fazenda Banda Alta, CA= Fazenda São Sebastião do Carandá e MO= Fazenda Monjolinho.

As famílias com maior número de espécies na Fazenda Banda Alta foram: Fabaceae e Poaceae (13), Malvaceae (8) e Cactaceae (6), Cyperaceae e Euphorbiaceae (5 espécies cada) (Figura 4). Já para a Fazenda S.S. Carandá as famílias mais ricas foram: Fabaceae (14), Poaceae (10) e Malvaceae (7) e Rubiaceae (6) (Figura 4). E, finalmente, para a Fazenda Monjolinho as famílias com maior riqueza específica foram: Poaceae (16), Fabaceae (12), Malvaceae (10) e Bromeliaceae e Cyperaceae (5 espécies cada) (Figura 4).

Os maiores valores dos índices de diversidade de Shannon obtidos foram para a Fazenda Banda Alta, seguida pela Fazenda São Sebastião do Carandá e pela Fazenda Monjolinho (Tabela 1). A equabilidade foi de 0,6442 para a Fazenda Banda Alta; 0,6798 para a Fazenda São Sebastião do Carandá e de 0,5011 para a Fazenda Monjolinho (Tabela 1). 
Tabela 1 - Valores dos índices de diversidade de Shannon $\left(\mathrm{H}^{\prime}\right)$, expressos em nats/indivíduos, e de equabilidade de Pielou (J) calculados para os três afloramentos rochosos ferruginosos estudados em Corumbá, MS.

\begin{tabular}{lll}
\hline Local & $\mathrm{H}^{\prime}$ (nats/indivíduos) & $\mathrm{J}$ \\
\hline Fazenda Banda Alta & 3,0947 & 0,6442 \\
Fazenda São Sebastião do Carandá & 3,1032 & 0,6798 \\
Fazenda Monjolinho & 2,4077 & 0,5011 \\
\hline
\end{tabular}

Cerca de um quarto do total de espécies amostradas ocorreu em todos os sítios estudados (47 espécies), entretanto, quarenta por cento do total de espécies (77 espécies) foi observado em uma única localidade (27 espécies exclusivas da Fazenda Banda Alta, 18 da Fazenda São Sebastião do Carandá e 32 da Fazenda Monjolinho) refletindo uma variabilidade na composição florística dos diferentes afloramentos rochosos ferruginosos apesar da pequena distância entre eles (Anexo 2).

Entre as espécies registradas em todas as localidades estudadas destacaramse as que se estabelecem diretamente sobre a rocha (Discocactus ferricola, Portulaca sp1 e Selaginella sellowii) e aquelas sobre um substrato raso (Tripogon spicatus e Sporobulus monandrus).

A contribuição de elementos das matas deciduais que circundam os lajedos na composição das ilhas de vegetação se deu, por exemplo, pelas espécies: Bauhinia pentandra, Astronium fraxinifolium, Myracrodruon urundeuva, Commiphora leptophloeos, Cereus bicolor, Combretum duarteanum, Anadenanthera colubrina, Pseudobombax marginatum e Tocoyena formosa (Anexo 1). 
Do total de espécies observadas, cerca de um terço $(34,4 \%)$ foi amostrado tanto em parcelas quanto em ilhas (66 espécies), quase metade das espécies (39\%), ocorreram exclusivamente sob a forma agrupada de ilhas de vegetação, especialmente fanerófitas e trepadeiras, (75 espécies) e somente 4 espécies (2,1\%) foram amostradas exclusivamente em parcelas (Hyptis brevipes, Portulaca sp2, Portulaca mucronata, Turnera cf pumilea) (Anexo 2).

As espécies vasculares que se estabelecem diretamente sobre a rocha também foram observadas em ilhas de solo mas, muitas vezes, ocupam as bordas das mesmas. Por outro lado, as ilhas de solo propiciam condições de sombreamento e maior quantidade de substrato e, consequentemente, de água disponível permitindo a colonização e estabelecimento de espécies mais exigentes quanto à condições de sombreamento e de maior porte.

\section{Formas de vida}

A forma de vida predominante para a vegetação das cangas de Corumbá foi de nanofanerófitas com 44 espécies, seguida por hemicriptófitas (37), microfanerófitas (36), lianas (27), caméfitas (19), terófitas (18), suculentas (5), epífitas e geófitas (2 spp cada) (Figura 6).

Quando comparado à normal de Raunkiaer, observou-se que as fanerófitas tiveram uma representatividade maior do que as hemicriptófitas nas cangas de Corumbá devido a proporção de espécies de maior porte amostradas na Fazenda S.S.Carandá (Figura 6). 
Nas Fazendas Banda Alta e Monjolinho as formas de vida predominantes foram: hemicriptófitas, nanofanerófitas e microfanerófitas, sendo que no primeiro local foram registradas as únicas geófitas e na Fazenda Monjolinho as únicas epífitas (Figura 7). As formas de vida predominantes da Fazenda São Sebastião do Carandá foram: nanofanerófitas, hemicriptófitas e microfanerófitas (Figura 7).

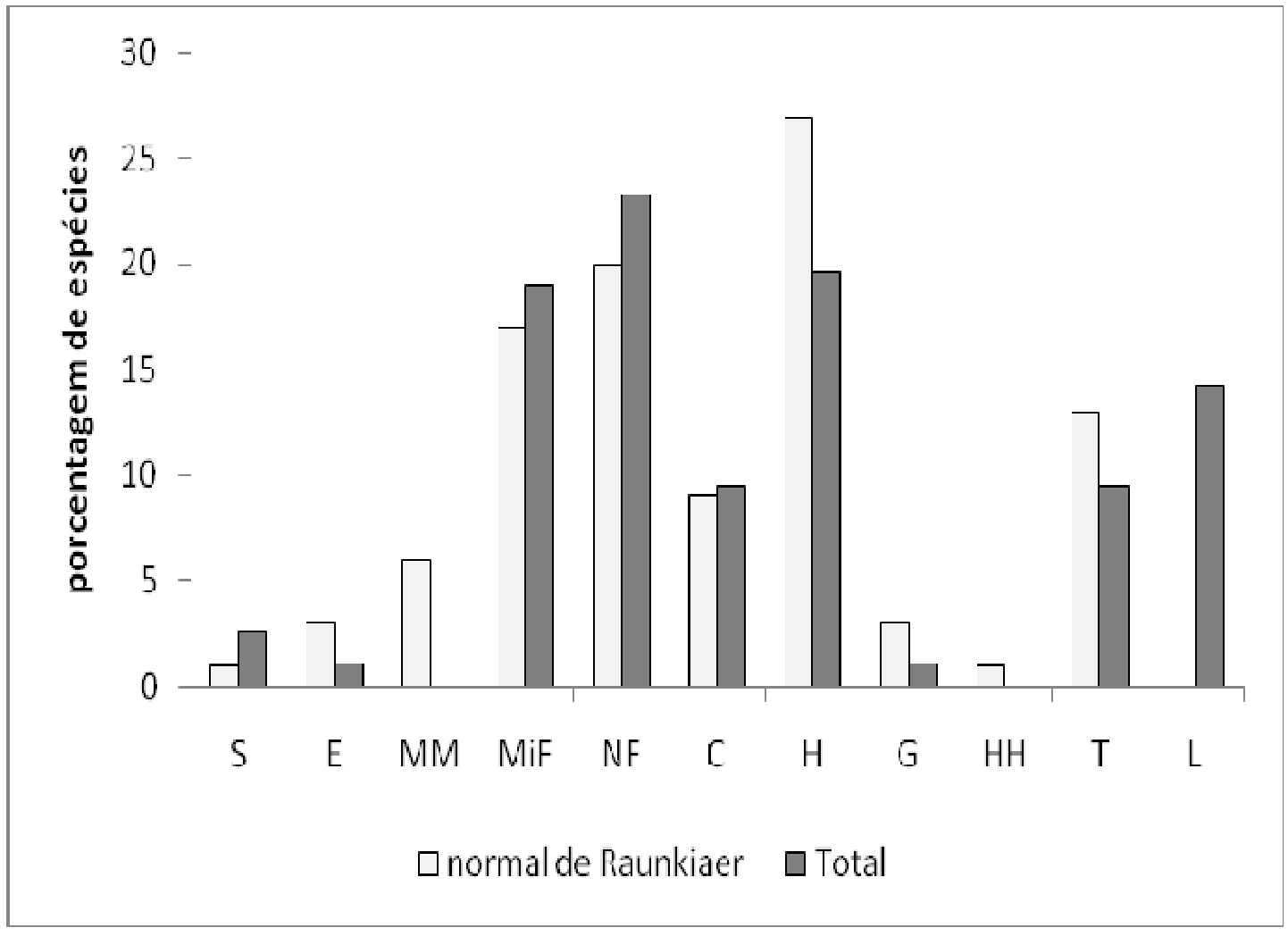

Figura 6 - Espectro biológico do total de espécies encontradas nos afloramentos rochosos ferruginosos de Corumbá, MS, comparado à proporção normal de Raunkiaer. $S=$ suculenta, $E=$ epífita, $M M=$ mega e mesofanerófita, MiF=microfanerófita, $\quad \mathrm{NF}=$ nanofanerófita, $\mathrm{C}=$ caméfita, $\mathrm{H}=$ hemicriptófita, $\mathrm{G}=$ geófita, $\mathrm{HH}=$ hidrófita, $\mathrm{T}=$ terófita, $\mathrm{L}=\mathrm{L}=$ liana. 


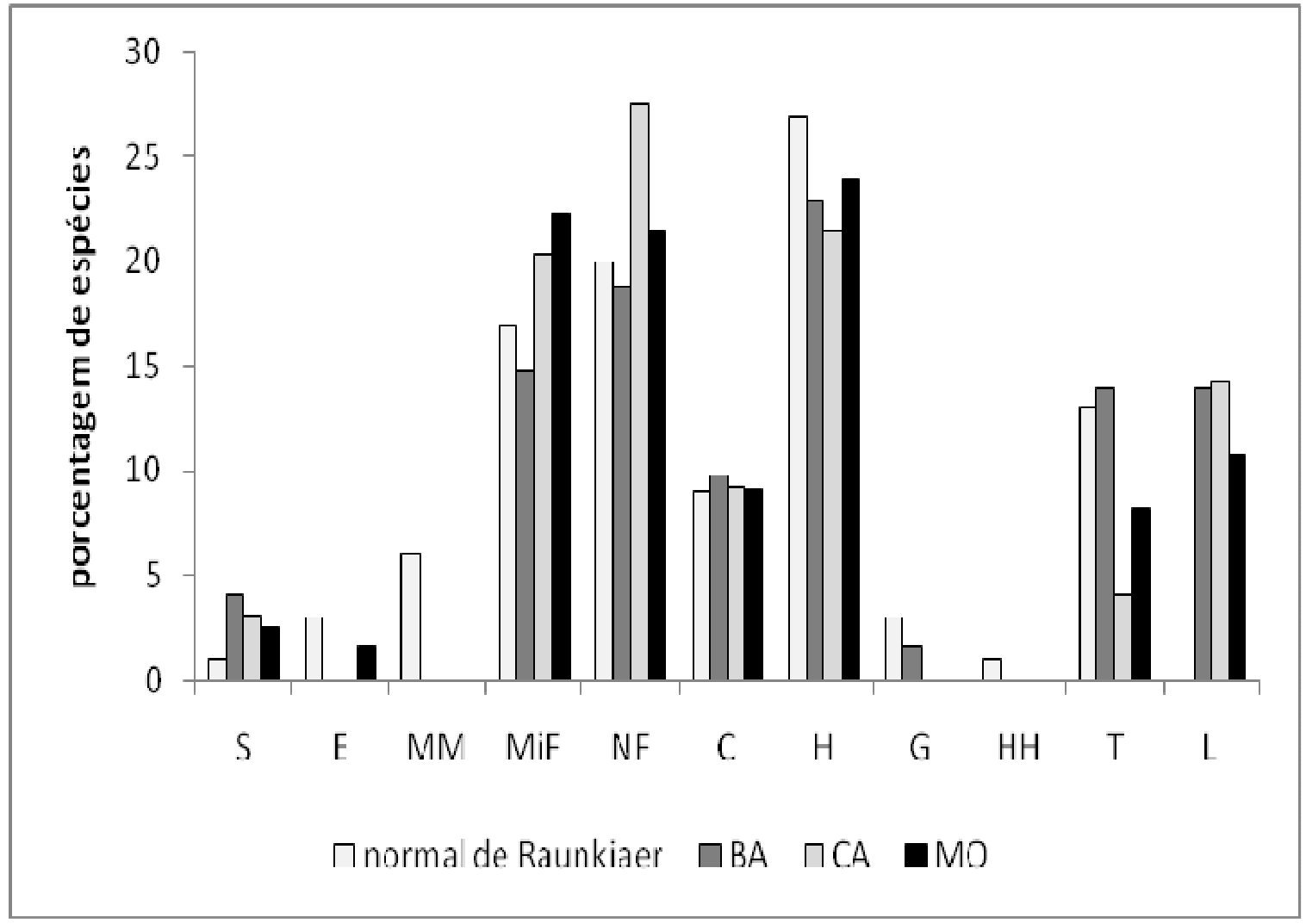

Figura 7 - Espectro biológico do total de espécies encontradas nos três afloramentos rochosos ferruginosos de Corumbá, MS, comparado à proporção

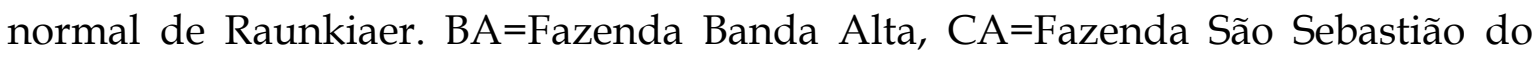
Carandá, MO=Fazenda Monjolinho. Os nomes das classes seguem a Figura 6.

\section{Estrutura da vegetação herbácea amostrada em parcelas de $1 \times 1 \mathrm{~m}$}

Em 199 parcelas amostradas, totalizando uma área de $199 \mathrm{~m}^{2}$, foram registradas 66 espécies, pertencentes a 27 famílias botânicas sendo cinco espécies de pteridófitas pertencentes a três famílias. A família com maior número de espécies foi Fabaceae (11), seguida por Poaceae (9), além de Cyperaceae, Malvaceae e Portulacaceae (5 espécies cada).

Cerca de $50 \mathrm{~m}^{2}$, do total da área amostrada, foram ocupados por rocha, pedras ou solo exposto. A Fazenda Banda Alta teve a maior proporção de área não 
vegetada $\left(36 \mathrm{~m}^{2}\right)$, seguida pela Fazenda Monjolinho $\left(7 \mathrm{~m}^{2}\right)$ e pela Fazenda São Sebastião do Carandá $\left(6 \mathrm{~m}^{2}\right)$.

As dez espécies com maiores valores de freqüência relativa, totalizando 58,6\%, foram: Selaginella sellowii (11,6\%), Mimosa nuda (6,4\%), Sporobulus monandrus (6,2\%), Tripogon spicatus (6\%), Mimosa xanthocentra (5,4\%), Staelia sp. $(5,1 \%)$, Waltheria operculata (5\%), Jacquemontia evolvuloides (5\%), Aeschynomene histrix (4,4\%) e Portulaca sp1 (3,3\%) (Anexo 1 e Figura 8).

As dez espécies com maiores valores de dominância relativa perfizeram 86,3\% do total: Selaginella sellowii (32,9\%), Sporobulus monandrus (16,4\%), Tripogon spicatus (6,9\%), Mesosetum chasae (5,9\%), Mimosa nuda (5,5\%), Mimosa xanthocentra $(5,4 \%)$, Cyperus uncinulatus (3,9\%), Jacquemontia evolvuloides $(3,4 \%)$, Staelia sp. (3,3\%) e Microchloa indica (2,7\%) (Anexo 1 e Figura 9). 


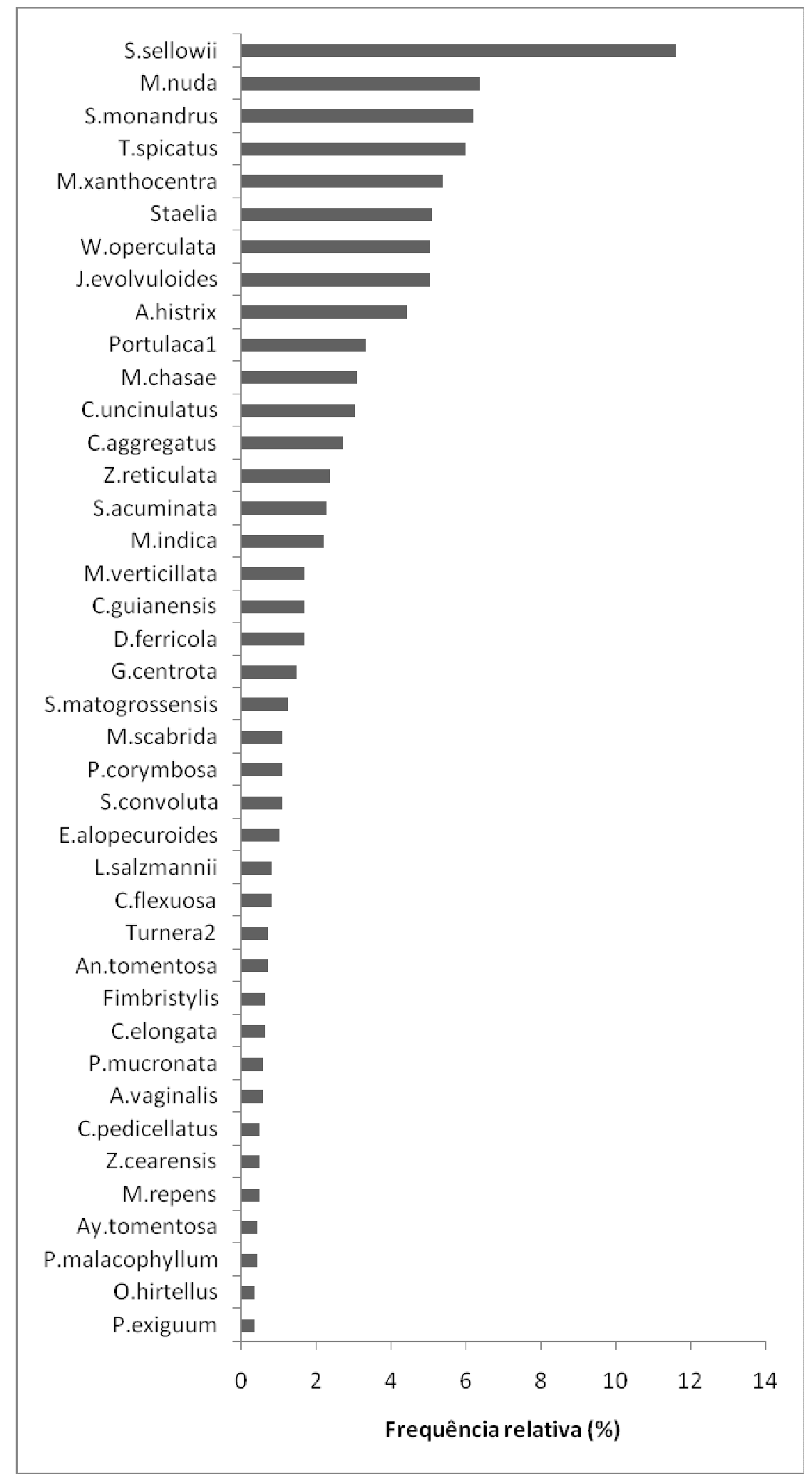

Figura 8 - Valores de frequência relativa para as primeiras quarenta espécies, em porcentagem, amostradas em parcelas de 1 × $1 \mathrm{~m}(\mathrm{n}=199)$ em afloramentos rochosos ferruginosos em Corumbá. MS. Para o nome das espécies consultar a Anexo 1. 


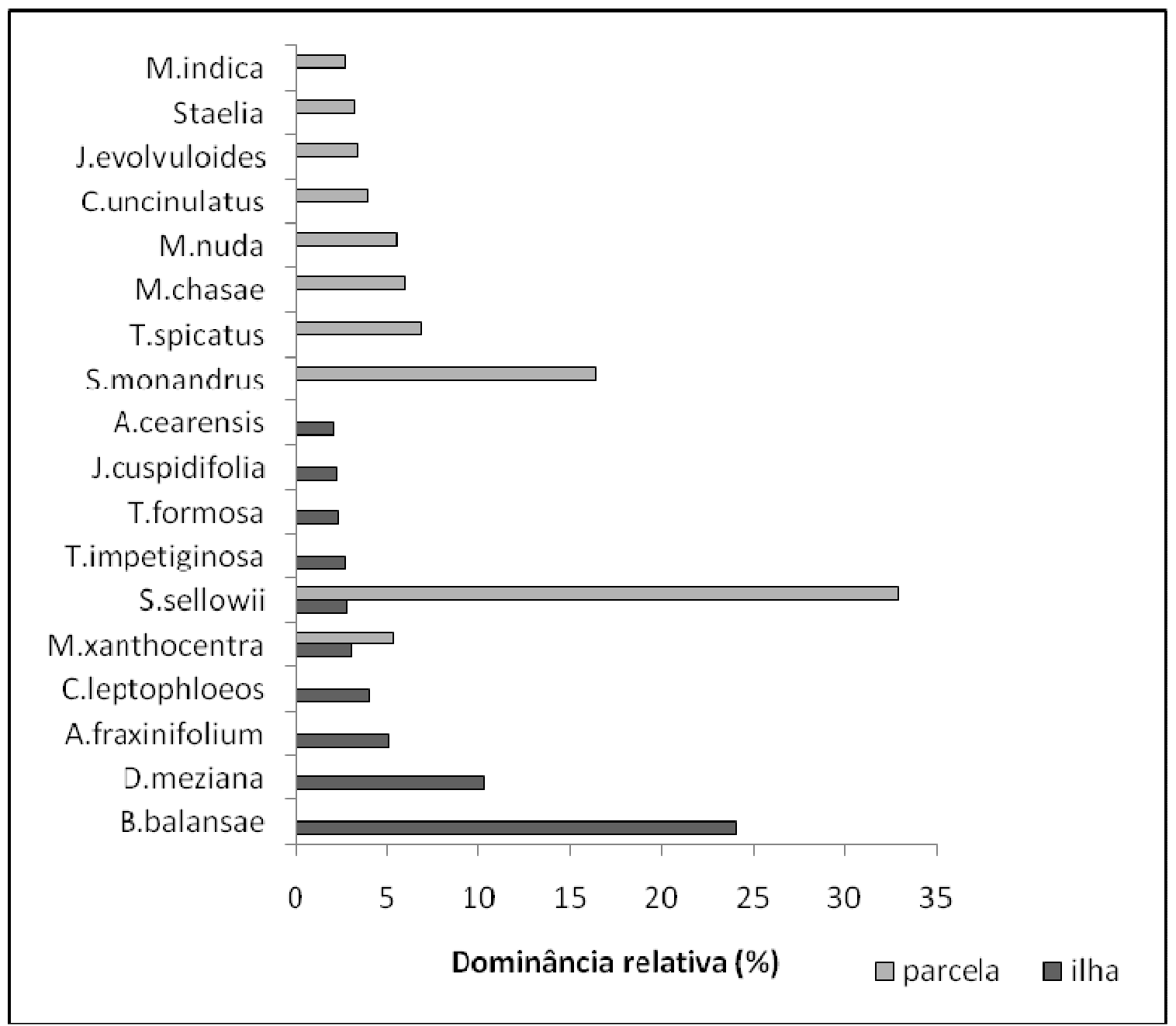

Figura 9 - Valores alcançados pelas dez espécies com maiores valores de dominância relativa (\%) em parcelas de $1 \times 1 \mathrm{~m}$ e em ilhas de solo amostradas em afloramentos rochosos ferruginosos em Corumbá, MS. Para o nome completo das espécies consultar a Anexo 1.

A vegetação que ocorre diretamente sobre a superfície rochosa formando um estrato herbáceo relativamente contínuo pode ser caracterizada pela presença de Selaginella sellowii e Sporobulus monandrus, as duas espécies com os maiores valores de importância (Anexo 1 e Figura 10). As dez espécies com maiores valores de importância perfizeram um total de 30,2\%: Selaginella sellowii (22,3\%), Sporobulus monandrus (11,3\%), Tripogon spicatus (6,4\%), Mimosa nuda (5,9\%), Mimosa 
xanthocentra (5,4\%), Mesosetum chasae (4,5\%), Jacquemontia evolvuloides (4,2\%), Staelia sp. (4,2\%), Cyperus uncinulatus (3,5\%), Waltheria operculata (3\%) (Anexo 1 e Figura 10).

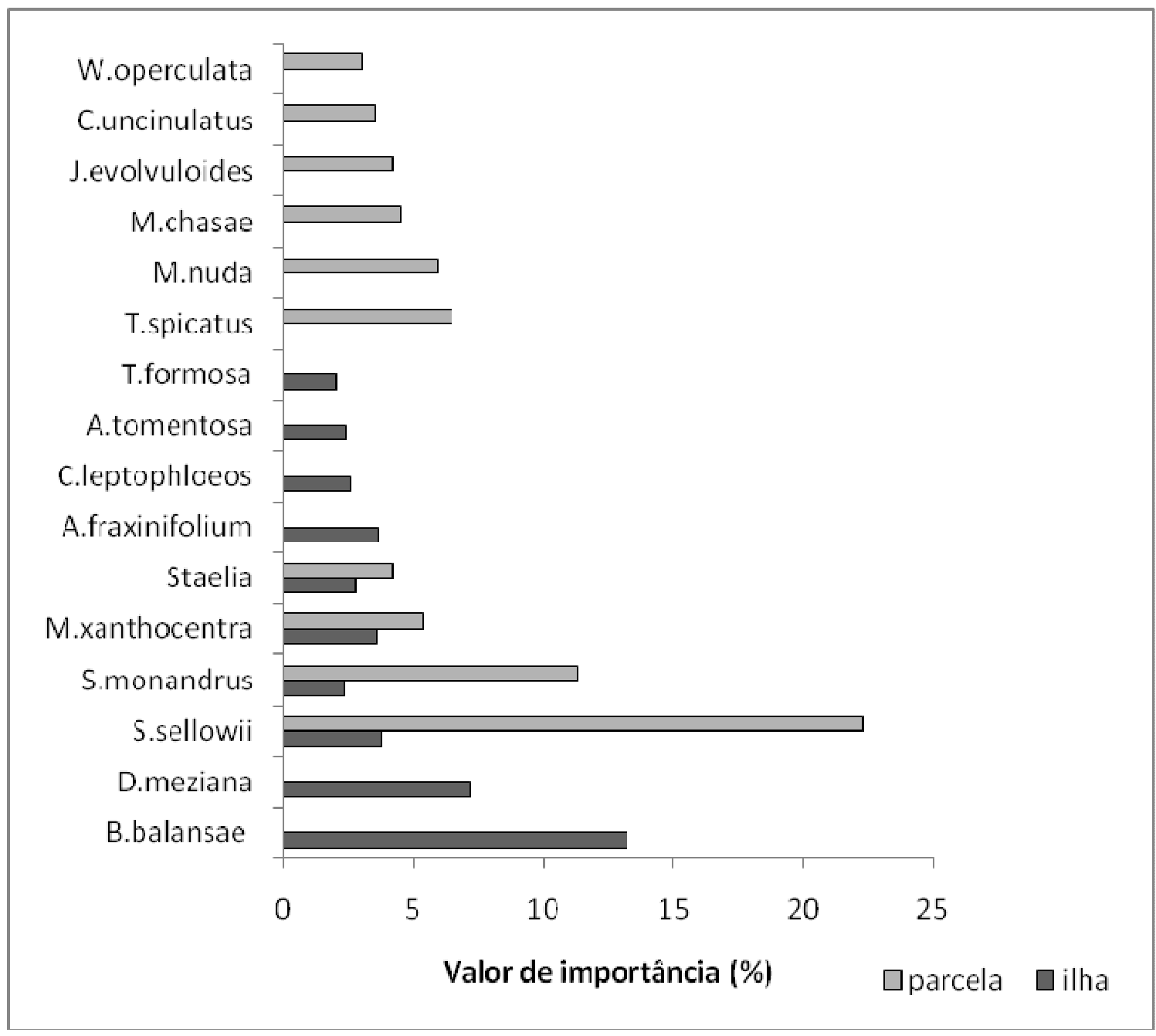

Figura 10 - Valores alcançados pelas dez espécies com maiores valores de importância em em parcelas de 1 x $1 \mathrm{~m}$ e ilhas de solo amostradas em afloramentos rochosos ferruginosos em Corumbá, MS. Para o nome completo das espécies consultar a Anexo 1.

A análise das curvas de rarefação para o número de espécies presentes nas unidades amostrais (parcelas de $1 \times 1 \mathrm{~m}$ ) revelou que somente a Fazenda São 
Sebastião do Carandá teve uma estabilização aparente na curva ao nível de 95\% (Figuras 11a e 11b).

A
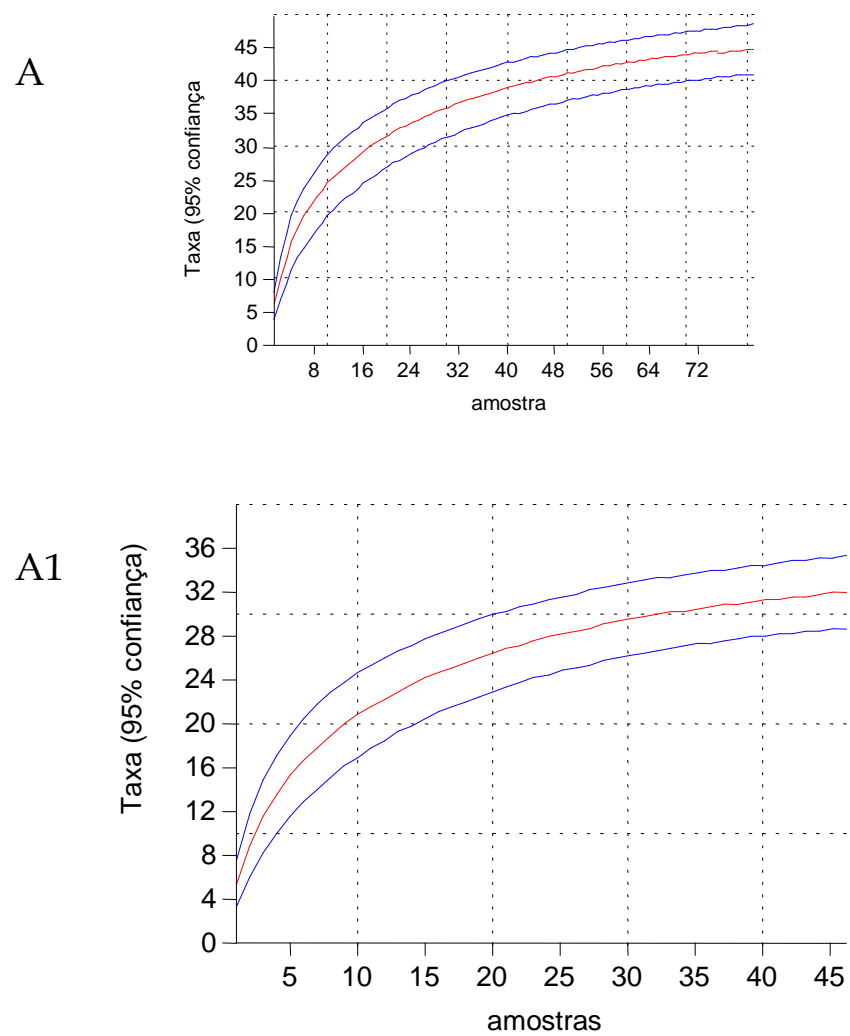

A2

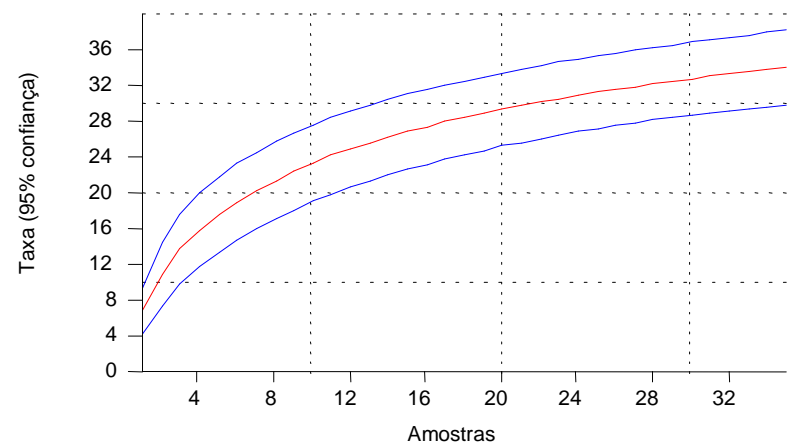

Figura 11a - Curvas de número acumulativo de espécies vasculares amostradas em parcelas de $1 \times 1 \mathrm{~m}$ baseadas em reamostragem aleatória (linha central) e intervalos de confiança de $95 \%$ (linhas superior e inferior) para as espécies amostradas em afloramentos rochosos ferruginosos em Corumbá, MS. A=Fazenda Banda Alta, A1=parcelas do "habitat seco", A2=parcelas do "habitat encharcado". 

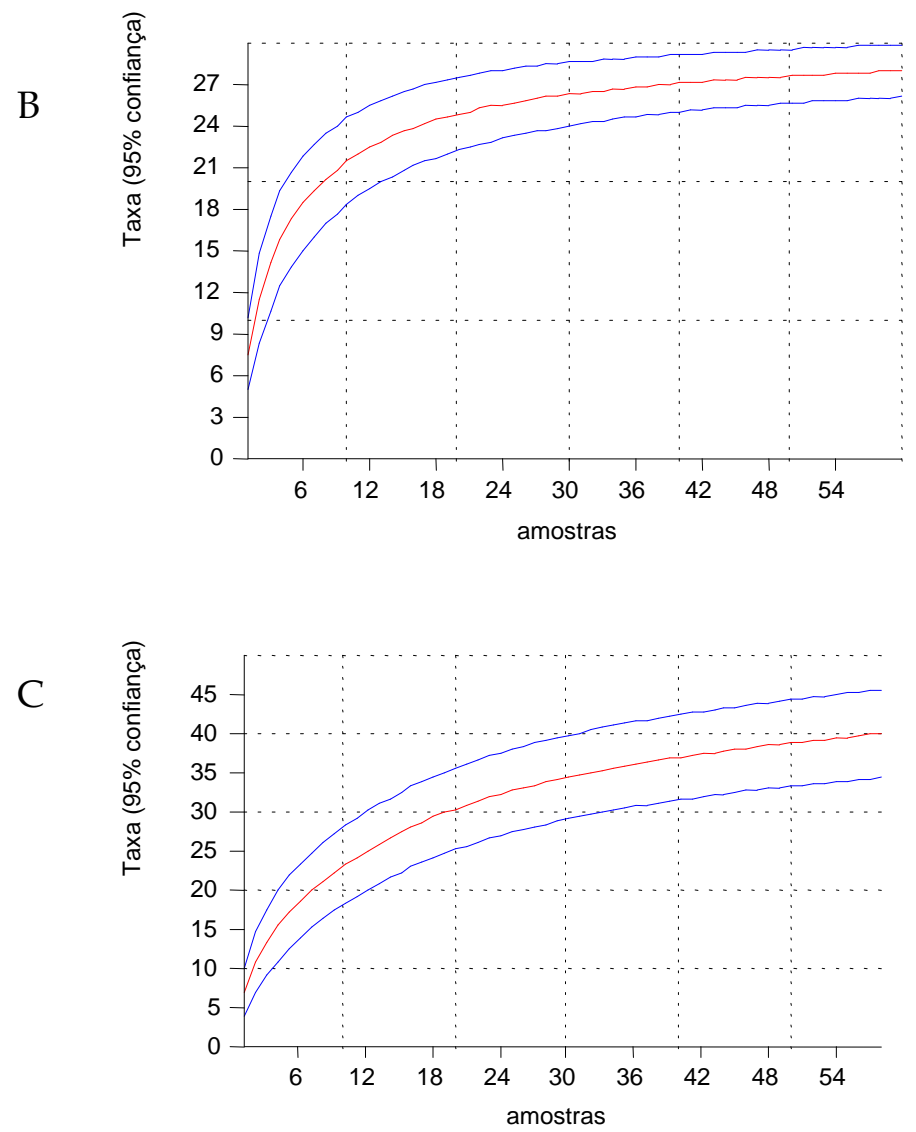

Figura 11b - Curvas de número acumulativo de espécies vasculares amostradas em parcelas de $1 \times 1 \mathrm{~m}$ baseadas em reamostragem aleatória (linha central) e intervalos de confiança de $95 \%$ (linhas superior e inferior) para as espécies amostradas em afloramentos rochosos ferruginosos em Corumbá, MS. B=Fazenda São Sebastião do Carandá, C=Monjolinho.

Os maiores valores do índice de diversidade de Shannon para a vegetação amostrada nas parcelas de $1 \times 1 \mathrm{~m}$ foram obtidos para a Fazenda Banda Alta, seguido pela Fazenda S.S.Carandá e pela Fazenda Monjolinho (Tabela 2). O índice de equabilidade para a comunidade insular da Fazenda Banda Alta foi de 0,6425, para a Fazenda S.S.Carandá foi 0,6989 e para a Fazenda Monjolinho foi 0,4555 (Tabela 2). 
Tabela 2 - Valores dos índices de diversidade de Shannon $\left(\mathrm{H}^{\prime}\right)$, expressos em nats/indivíduos, e de equabilidade de Pielou (J) calculados para a vegetação do estrato herbáceo amostrada em três afloramentos rochosos ferruginosos em Corumbá, MS.

\begin{tabular}{lll}
\hline Local & $\mathrm{H}^{\prime}$ (nats/indivíduo) & $\mathrm{J}$ \\
\hline Fazenda Banda Alta & 2,4415 & 0,6425 \\
Fazenda S.S.Carandá & 2,3292 & 0,6989 \\
Fazenda Monjolinho & 1,6803 & 0,4555 \\
\hline
\end{tabular}

\section{Formas de vida}

A forma de vida predominante para a vegetação que ocorre no estrato herbáceo dos afloramentos rochosos foi de caméfitas (19), seguida por hemicriptófitas (17), nanofanerófitas (15), terófitas (7), lianas (4), geófitas (2) e microfanerófitas e suculentas (1 cada) (Figura 12).

Quando comparado à normal de Raunkiaer, observou-se que as caméfitas foram mais relevantes do que as fanerófitas já que os atributos ambientais do substrato rochoso não favorecem o estabelecimento de espécies de maior porte (Figura 12).

Analisando-se a distribuição das formas de vida por localidade observou-se a Fazenda Banda Alta teve a mesma proporção do espectro biológico para a totalidade de espécies, ressaltando-se a ocorrência das únicas geófitas amostradas nas cangas de Corumbá (Figura 13). A proporção de caméfitas, hemicriptófitas e nanofanerófitas para a Fazenda S.S.Carandá foi semelhante (Figura 13). As hemicriptófitas, caméfitas e nanofanerófitas foram as formas de vida mais 
importantes na Fazenda Monjolinho e neste local forma registradas as únicas microfanerófitas (Figura 13).

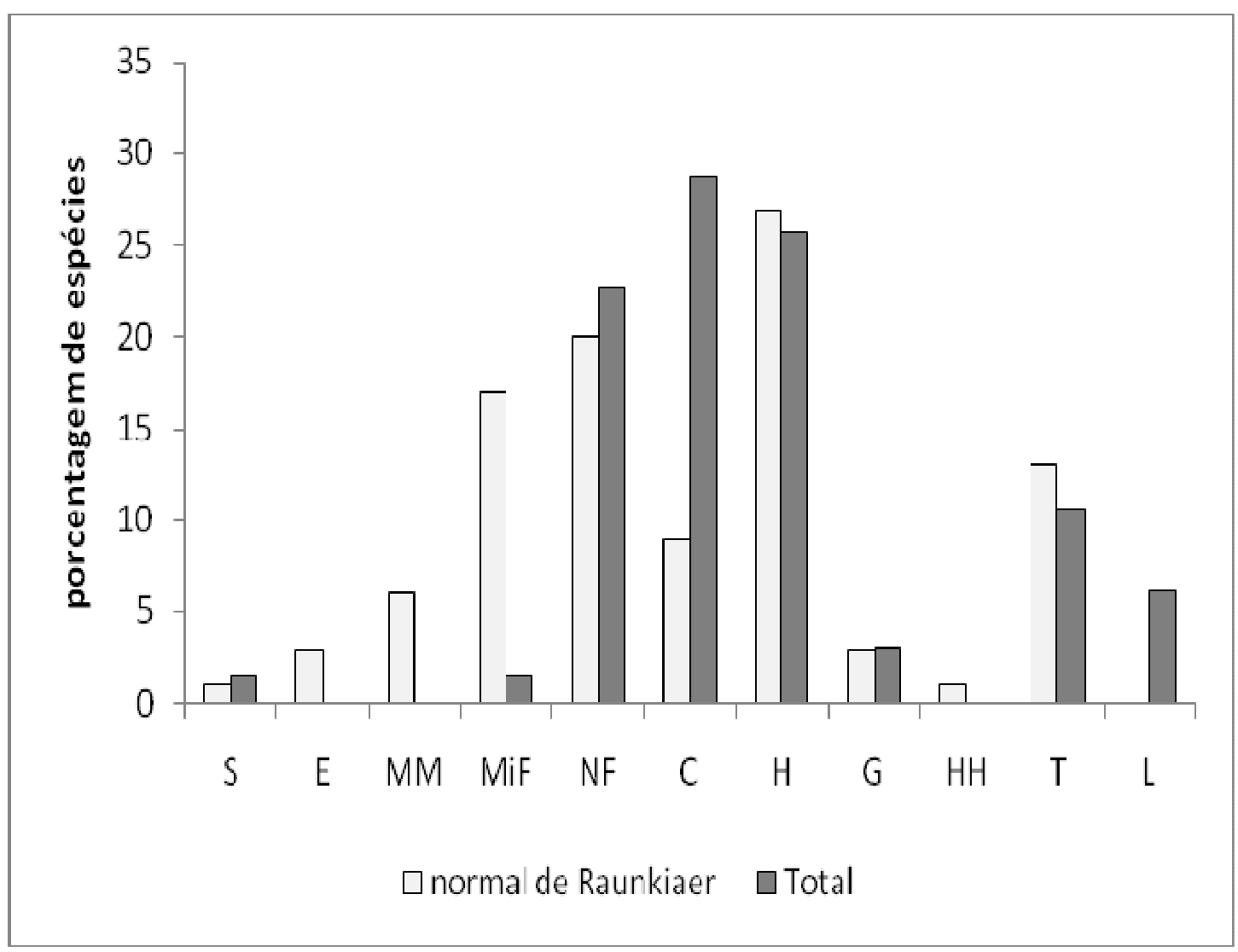

Figura 12 - Espectro biológico do total de espécies do estrato herbáceo amostradas em parcelas de $1 \times 1 \mathrm{~m}$ nos afloramentos rochosos ferruginosos de Corumbá, MS, comparado à proporção normal de Raunkiaer. $S=$ suculenta, E=epífita, MM=mega e mesofanerófita, $\mathrm{MiF}=$ microfanerófita, $\mathrm{NF}=$ nanofanerófita, $\mathrm{C}=$ caméfita, $\mathrm{H}=$ hemicriptófita, $\mathrm{G}=$ geófita, $\mathrm{HH}=$ hidrófita, $\mathrm{T}=$ =terófita, L=liana. 


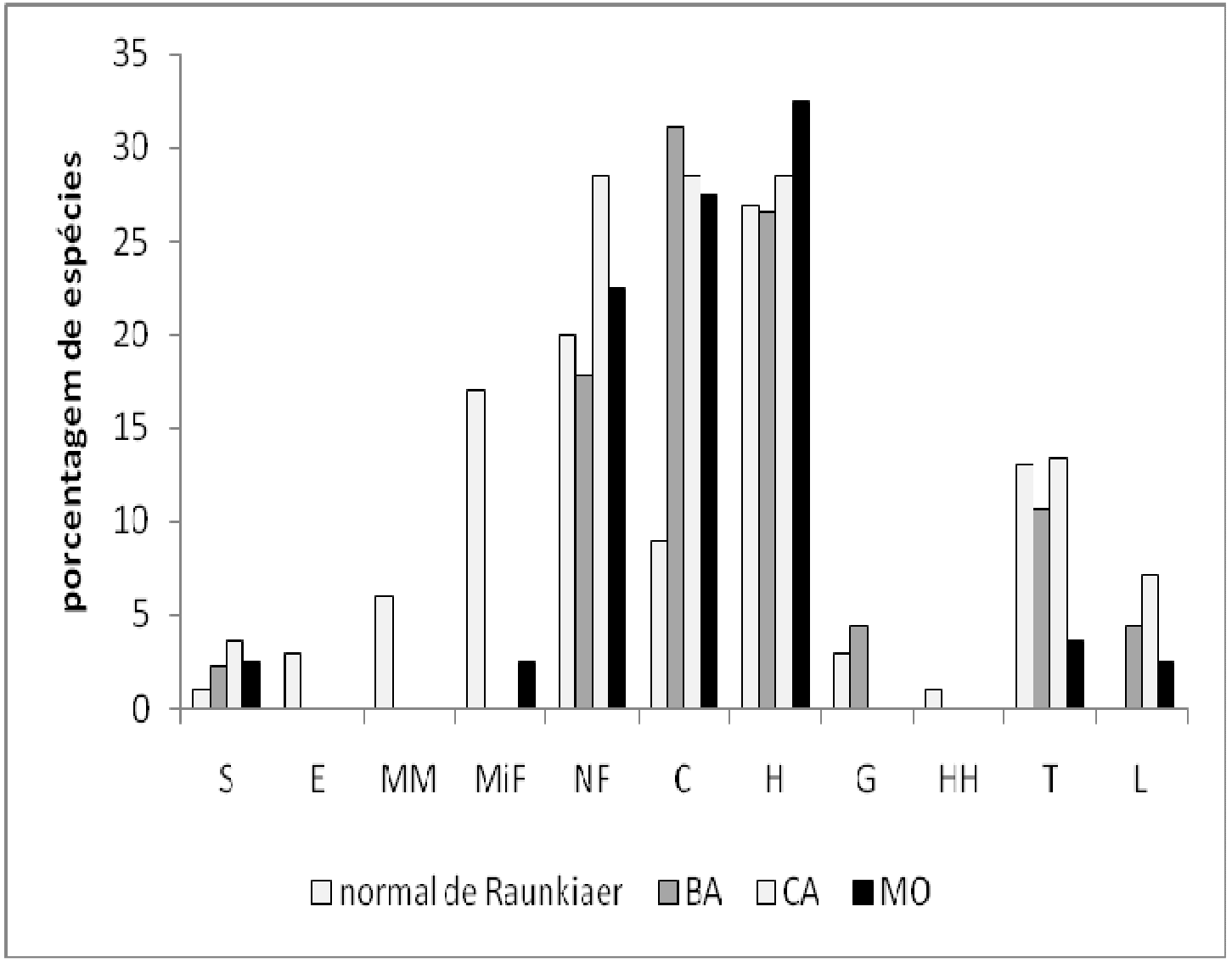

Figura 13 - Espectro biológico do total de espécies do estrato herbáceo amostradas em parcelas de $1 \times 1 \mathrm{~m}$ nos afloramentos rochosos ferruginosos de Corumbá, MS, comparado à proporção normal de Raunkiaer. BA=Fazenda Banda Alta, $\mathrm{CA}=$ Fazenda S.S.Carandá, $\mathrm{MO}=$ Fazenda Monjolinho. Os nomes das classes seguem a mesma da Figura 12.

O desenho esquemático da vegetação em perfil do estrato herbáceo das cangas de Corumbá da Fazenda Banda Alta ilustra a distribuição esparsa das plantas, de porte predominantemente herbáceo e com a presença de espécies litólicas, como Discocactus ferricola e Polycarpaea corymbosa (Figura 14). 

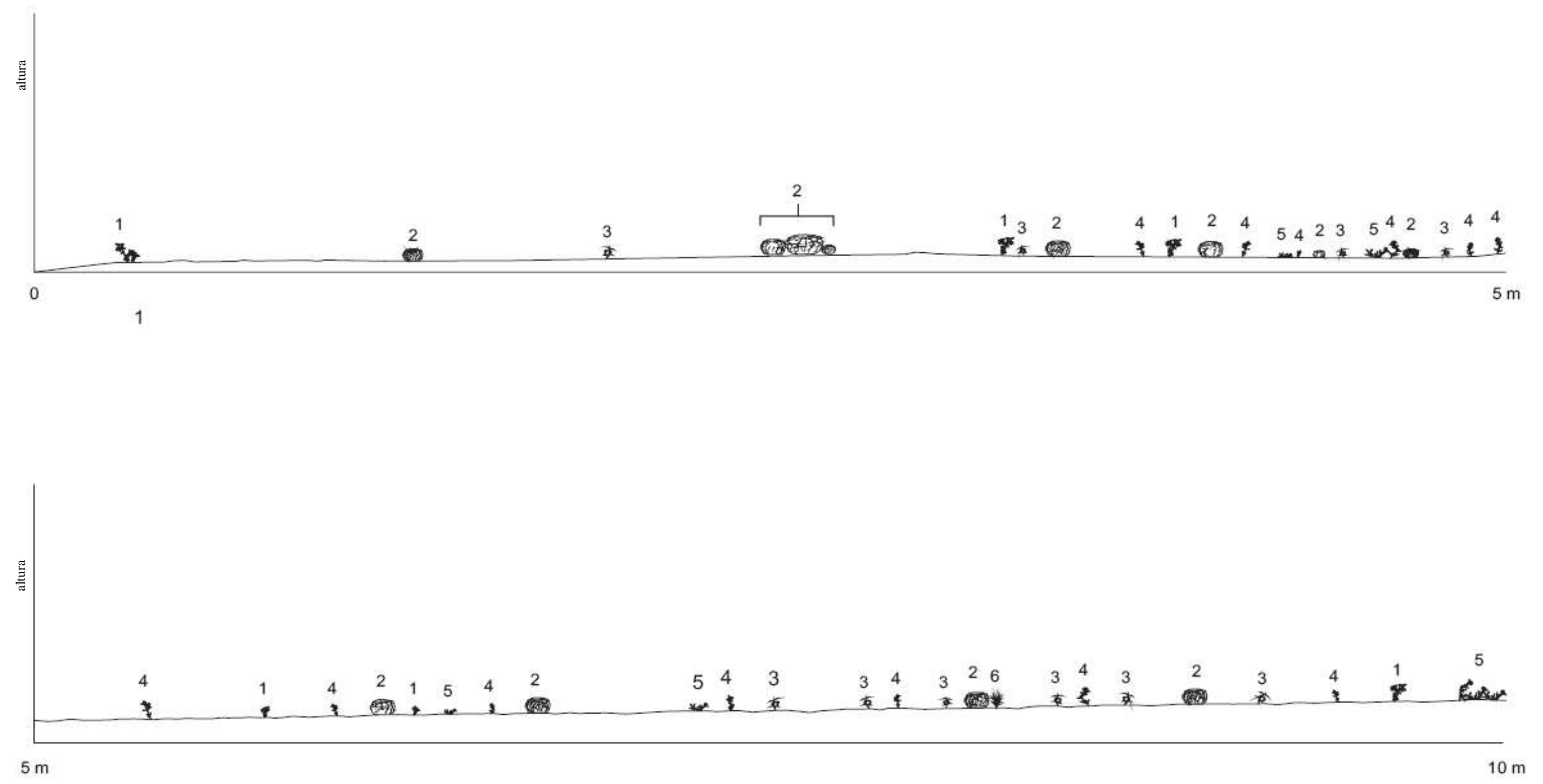

62 
Figura 14 - Desenho esquemático da vegetação em perfil correspondente a um trecho de 2 x $10 \mathrm{~m}$ do estrato herbáceo estabelecido diretamente sobre a superfície rochosa na Fazenda Banda Alta, Ladário, MS. O código das espécies utilizado foi: 1=Portulaca sp1, 2=Discocactus ferricola, 3=Gomphrena centrota, 4=Polycarpaea corymbosa, 5=Selaginella sellowii, 6=Tripogon spicatus. 


\section{Habitats "seco" e "encharcado" da Fazenda Banda Alta}

Para a avaliação quantitativa da vegetação do estrato herbáceo da Fazenda Banda Alta definiu-se, previamente, dois habitats: "seco" e "encharcado", em função da heterogeneidade da superfície rochosa. A Figura 15 evidenciou a segregação entre estes dois habitats e a análise de variância para os valores de cobertura e composição florística nas 81 parcelas de 1 × $1 \mathrm{~m}$ revelou que a composição e cobertura da vegetação nestes dois ambientes foi significativamente diferente $(\mathrm{df}=80, \mathrm{~F}=28,734, \mathrm{P}<0,001)$ (Figura 15).

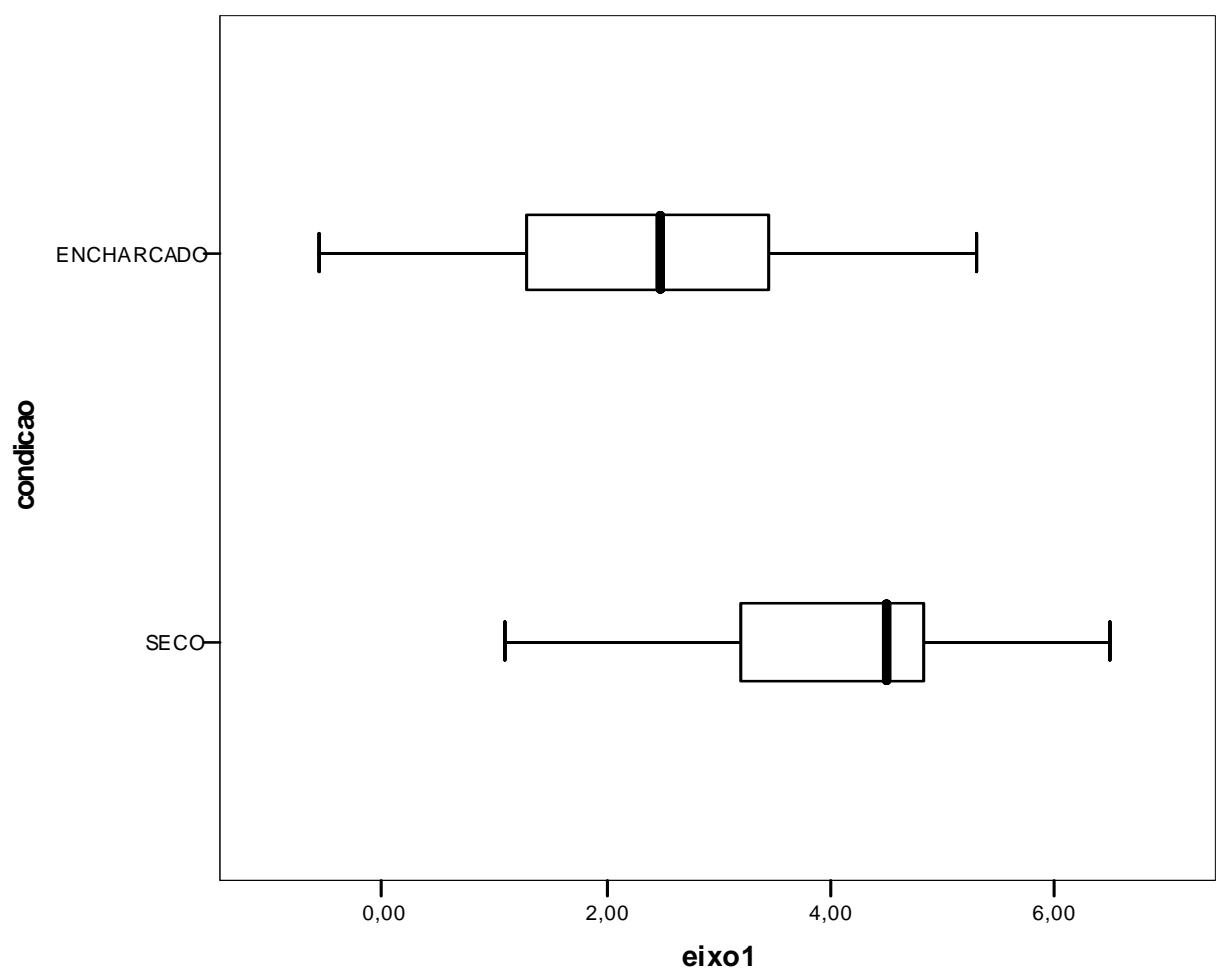

Figura 15 - Gráfico tipo "Box-plot" representando a mediana e o intervalo de confiança de $95 \%$ para os dados de cobertura e composição da vegetação herbácea amostrada nas parcelas de $1 \times 1 \mathrm{~m}$ nos habitats "seco" e "encharcado" na Fazenda Banda Alta, Ladário, MS. 


\section{Análises de Ordenação para a vegetação amostrada em parcelas de 1 x 1 m}

\section{- Fazenda Banda Alta}

A análise de coordenadas principais (PCO) para a matriz com dados de cobertura de 32 espécies e dois atributos abióticos, solo e rocha, (aquelas com três ou mais ocorrências) nas 81 parcelas de $1 \times 1$ m revelou que o eixo 1 explicou $16 \%$ da variação dos dados enquanto o eixo 2 explicou 8,1\%, perfazendo um total de $24,1 \%$ de informação da matriz.

A interpolação entre os eixos 1 e 2 da PCO (Figura 16) mostrou a segregação entre as parcelas do "habitat seco" (aquelas sobre a superfície rochosa lisa) das parcelas alocadas no "habitat encharcado"(estabelecidas sobre uma superfície rochosa rugosa paralela ao Córrego Banda Alta). As parcelas do "habitat encharcado" encontram-se ao longo do lado positivo do eixo 1 e constituem um gradiente ambiental longo (Figura 16).

Esta análise de ordenação e as correlações de Pearson entre os escores dos primeiros eixos da PCO e os valores de cobertura e composição de espécies revelaram que Gomphrena centrota $(\mathrm{r}=-0,459)$, Portulaca $\mathrm{sp} 1(\mathrm{r}=-0,373)$ e Discocactus ferricola $(\mathrm{r}=-0,203)$ ocorreram em locais com maiores proporções de rocha exposta $(\mathrm{r}=-0,857)$. Por outro lado, as espécies Mimosa xanthocentra $(\mathrm{r}=0,610)$, Cyperus uncinullatus $(\mathrm{r}=0,536)$, Selaginella convoluta $(\mathrm{r}=0,477)$ e Jacquemontia evolvuloides $(\mathrm{r}=0,452)$ distribuíram-se em locais com presença de um substrato raso. A distribuição das parcelas ao longo do eixo 2 da PCO foi definido pela presença da pteridófita Selaginella sellowii $(\mathrm{r}=0,863)$ em contraposição à maior proporção de 
rocha exposta $(\mathrm{r}=-0,476)$ e a ocorrência das espécies Alysicarpus vaginalis $(\mathrm{r}=-0,347)$

e Cipura formosa $(\mathrm{r}=-0,306)$.

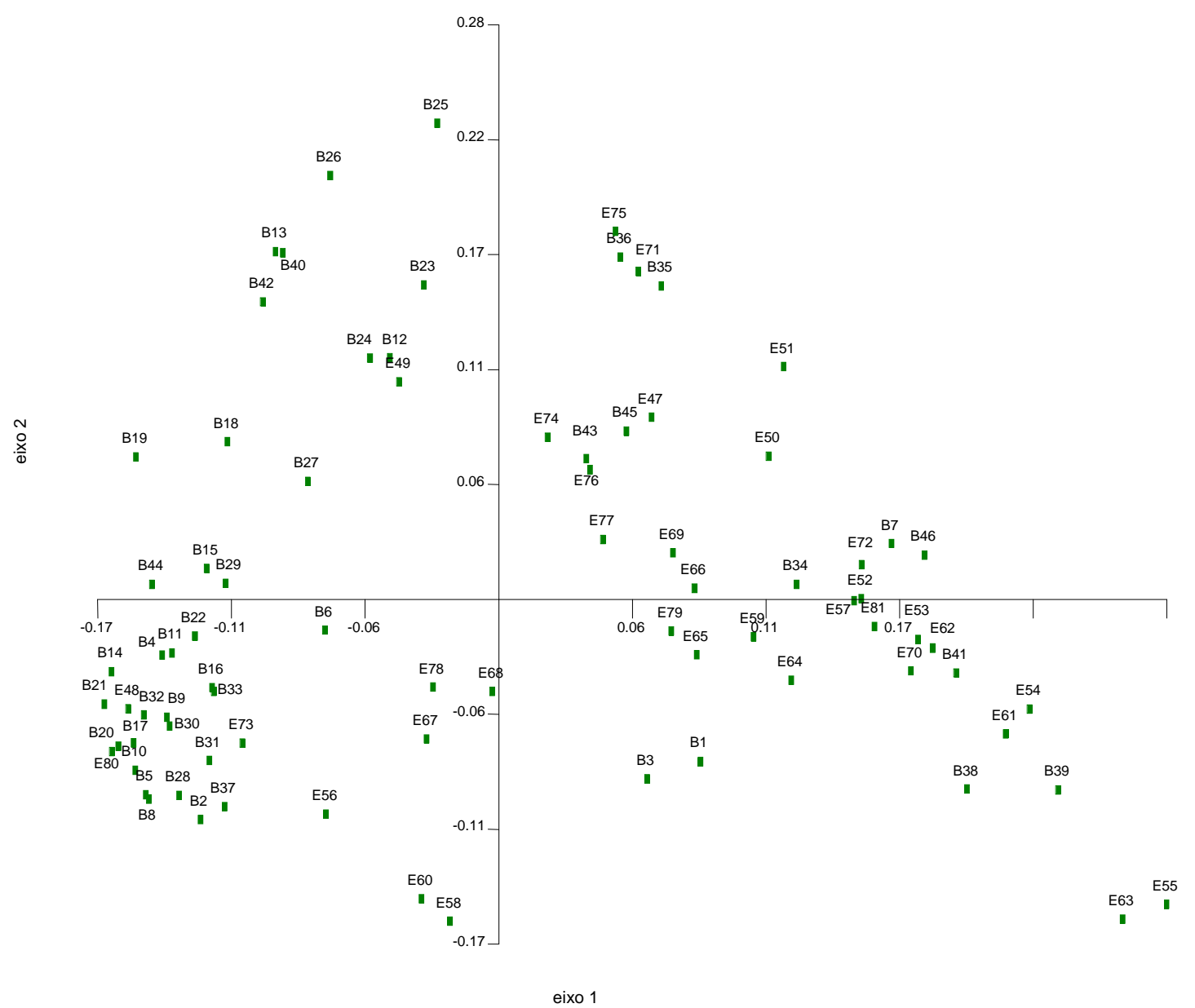

Figura 16 - Interpolação dos escores das espécies dois primeiros eixos resultantes da análise de coordenadas principais (PCO), utilizando o coeficiente de distância de Gower, aplicada à matriz de dados padronizados com os valores de cobertura para as espécies com três ou mais ocorrências amostradas nas parcelas de $1 \times 1 \mathrm{~m}$ nos afloramentos rochosos ferruginosos na Fazenda Banda Alta, em Ladário, MS. $\mathrm{B}=$ parcelas amostradas no "habitat seco" e $\mathrm{E}=$ parcelas amostradas no "habitat encharcado". 
A análise de correspondência destendencionada (DCA) para a matriz com dados de cobertura de 32 espécies além de dois atributos abióticos (superfície rochosa e solo) (aquelas com três ou mais ocorrências) nas 81 parcelas de $1 \times 1 \mathrm{~m}$ amostradas na Fazenda Banda Alta mostrou que o eixo 1 explicou 11,5\% da variação dos dados enquanto o eixo 2 explicou 6,6\%, perfazendo um total de 18,1\% de informação da matriz.

A interpolação entre os eixos 1 e 2 da DCA na Fazenda Banda Alta evidenciou a segregação entre as espécies amostradas nas parcelas do "habitat seco", no lado esquerdo do eixo 1, e as espécies das parcelas alocadas no "habitat encharcado", no lado direito do eixo (Figura 17). As Figuras 17 e 18 também mostraram um grupo de parcelas com uma maior proporção de rocha exposta e as espécies Discocactus ferricola, Gomphrena centrota, Polycarpaea corymbosa, Portulaca sp1 e Selaginella sellowii (destacadas em um círculo) no lado esquerdo do eixo 1. No outro extremo do eixo 1 foram agrupadas as parcelas com as espécies que se estabelecem sobre um substrato raso como as geófitas, Cipura formosa e Zephyranthes cearensis, as ciperáceas Kyllinga odorata, Fimbristylis sp. e Cyperus uncinullatus, o arbusto Mimosa xanthocentra e a pteridófita Selaginella convoluta (Figura 18). As parcelas com maiores proporções de solo exposto estiveram relacionadas com a presença de Sporobolus monandrus e de Mimosa nuda (Figura 18). 


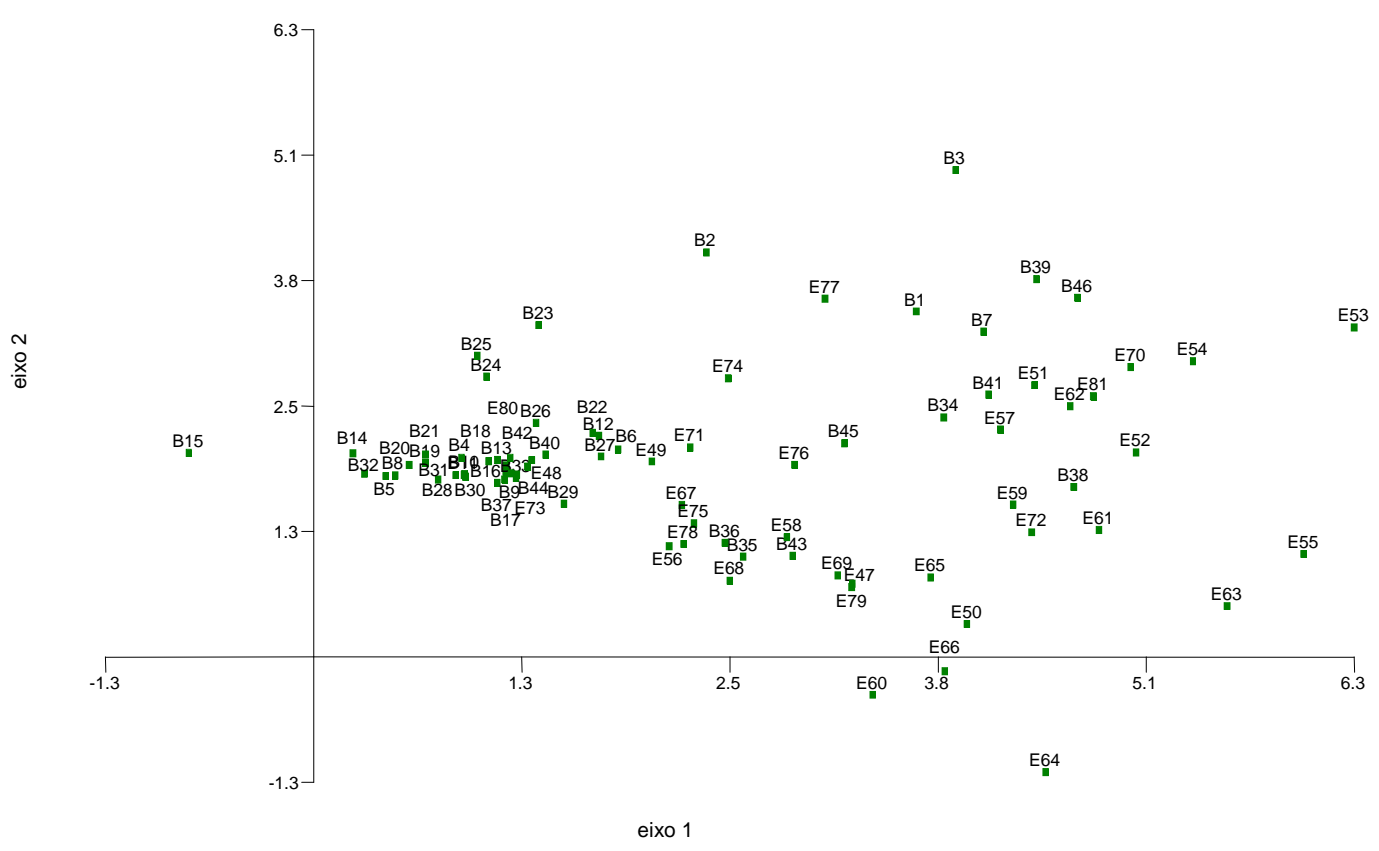

Figura 17 - Interpolação dos escores das parcelas dos dois primeiros eixos resultantes da análise de correspondência modalidade DCA, utilizando o coeficiente de Hill, aplicada à matriz de dados padronizados com os valores de cobertura para as espécies com três ou mais ocorrências amostradas nas parcelas de $1 \times 1 \mathrm{~m}$ nos afloramentos rochosos ferruginosos na Fazenda Banda Alta, em Ladário, MS. B=parcelas amostradas no "habitat seco" e E= parcelas amostradas no "habitat encharcado". 


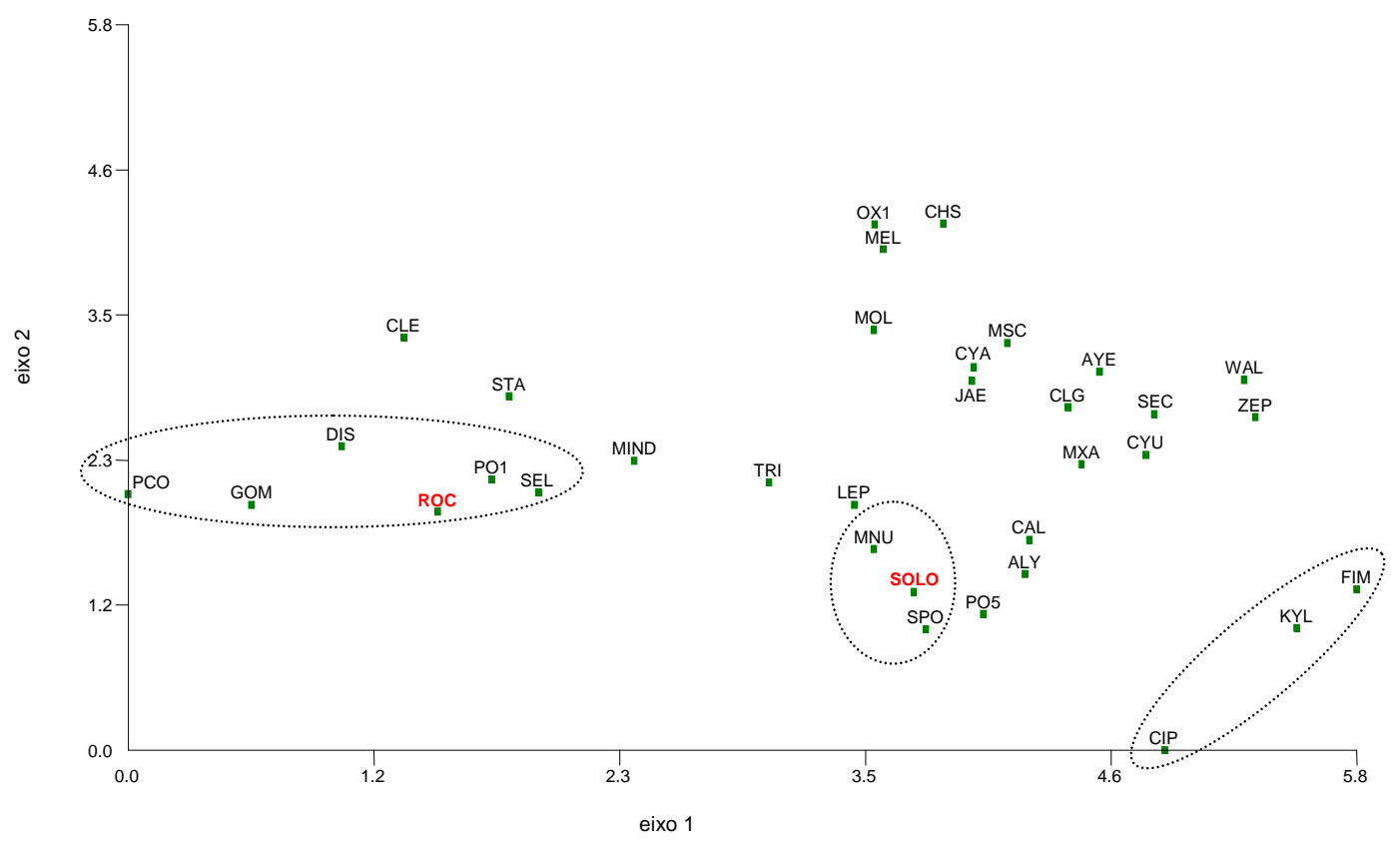

Figura 18 - Interpolação dos valores obtidos pela análise de correspondência modalidade DCA, utilizando o coeficiente de Hill, aplicada à matriz de dados padronizados com os valores de cobertura para as espécies com três ou mais ocorrências amostradas nas parcelas de $1 \times 1 \mathrm{~m}$ nos afloramentos rochosos ferruginosos na Fazenda Banda Alta, em Ladário, MS. As elipses representam grupos de espécies associadas a uma maior proporção de substrato rochoso, ou solo, e um terceiro com espécies relacionadas a locais mais úmidos (ver texto para maiores detalhes). As abreviaturas para os nomes das espécies constam no Anexo 2 . 


\section{- Fazenda São Sebastião do Carandá}

A análise de ordenação de coordenadas principais (PCO) aplicada à matriz com dados de cobertura de 24 espécies com três ou mais ocorrências, além da cobertura por rocha e solo nas 60 parcelas de $1 \times 1 \mathrm{~m}$ mostrou que o eixo 1 explicou 12,5\% da variação dos dados enquanto o eixo 2 explicou 10,2\%, perfazendo um total de 22,7\% de informação da matriz.

A interpolação entre os eixos 1 e 2 do PCO e as correlações de Pearson mostraram um gradiente ambiental onde as parcelas do lado negativo do eixo 1 apresentaram maiores proporções de rocha exposta $(r=-0,351)$ e a presença de Selaginella sellowii $(\mathrm{r}=-0,527)$ e de Portulaca sp1 $(\mathrm{r}=-0,260)$ e as parcelas do lado oposto do eixo apresentaram espécies características de ambientes com substrato raso Turnera cf. pumilea $(\mathrm{r}=0,737)$ e Waltheria operculata $(\mathrm{r}=0,650)$ (Figura 19). A distribuição das parcelas ao longo do eixo 2 da PCO foi definida por parcelas com a ocorrência das gramíneas Mesosetum chaseae $(\mathrm{r}=0,518)$ e Paspalum malacophyllum $(\mathrm{r}=0,418)$ e do arbusto Mimosa xanthocentra $(\mathrm{r}=0,482)$ em contraposição à parcelas com a gramínea Sporobulus monandrus $(\mathrm{r}=-0,847)$. 


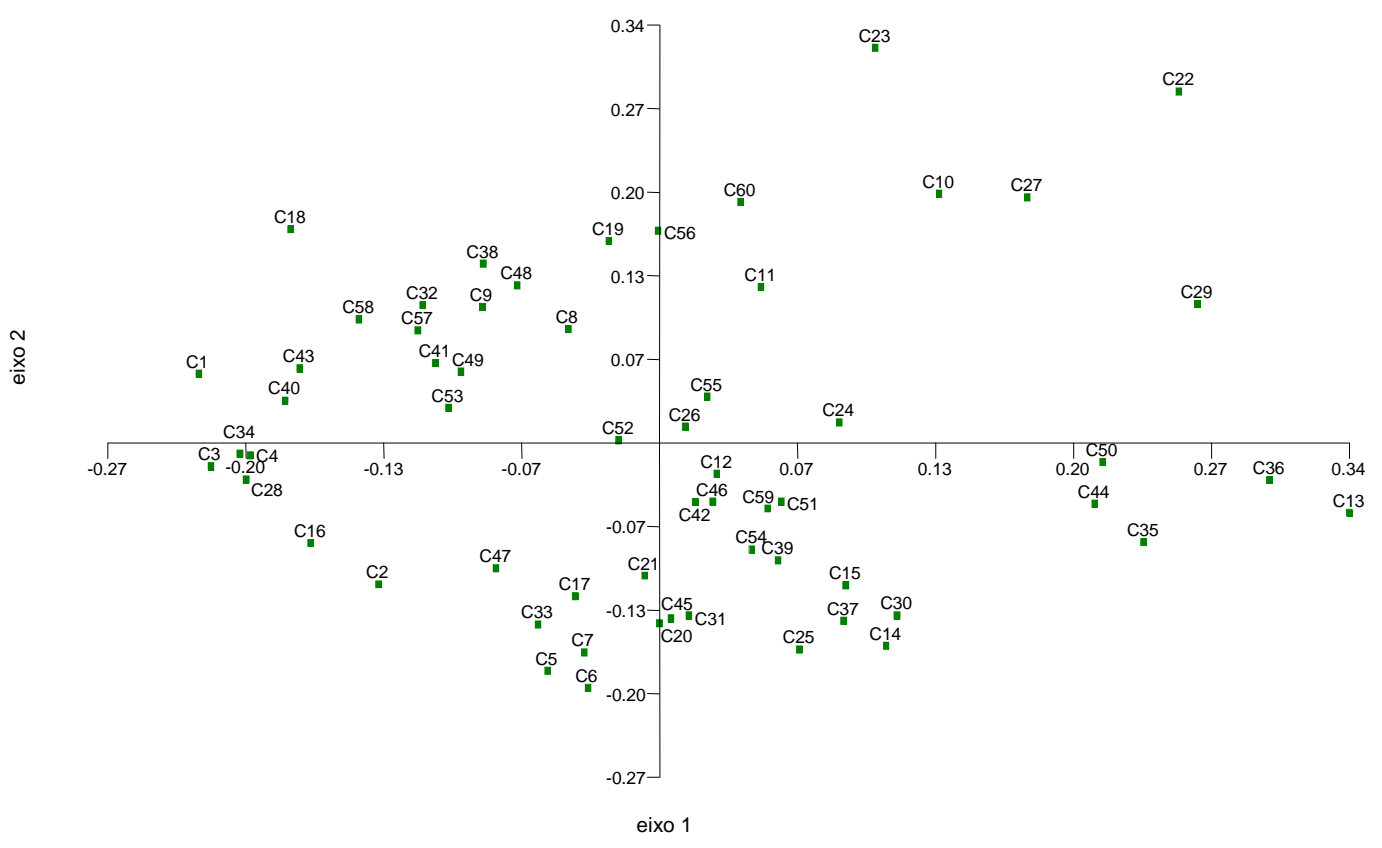

Figura 19 - Interpolação de escores de espécies dos dois primeiros eixos resultantes da análise de coordenadas principais (PCO), utilizando o coeficiente de distância de Gower, aplicada à matriz de dados padronizados com os valores de cobertura para as espécies com três ou mais ocorrências amostradas nas parcelas de 1 x $1 \mathrm{~m}$ nos afloramentos rochosos ferruginosos na Fazenda São Sebastião do Carandá, em Ladário, MS.

A análise de correspondência destendencionada (DCA) para a matriz com dados de cobertura de 24 espécies e os atributos abióticos, rocha e solo (aquelas com duas ou mais ocorrências), nas 60 parcelas de $1 \times 1 \mathrm{~m}$ mostrou que o eixo 1 explicou 15,1\% da variação dos dados enquanto o eixo 2 explicou 8,5\%, perfazendo um total de $23,6 \%$ de informação da matriz. 
A interpolação entre os eixos 1 e 2 da DCA mostrou o gradiente ambiental entre as espécies amostradas nas parcelas ao longo do eixo 1, com as parcelas com maior proporção de rocha exposta e a presença de espécies que se estabelecem diretamente sobre ela, como Portulaca sp1e Selaginella sellowii ficaram agrupadas no lado direito do eixo 1 (Figuras 20 e 21). Já as parcelas com espécies associadas a um substrato mais profundo agruparam-se no canto esquerdo da Figuras 20 e 21.

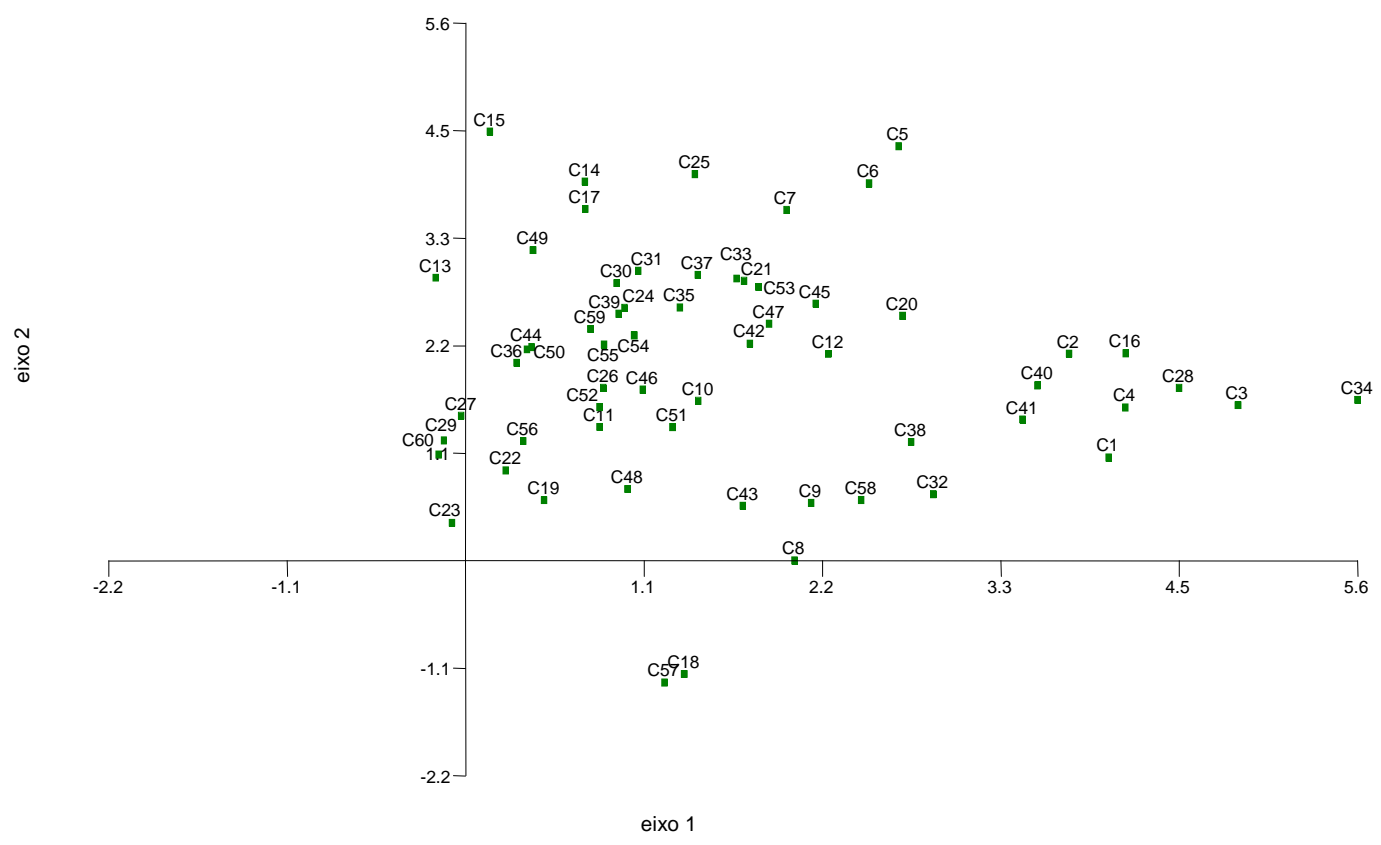

Figura 20 - Interpolação de escores de parcelas dos dois primeiros eixos resultantes da análise de correspondência modalidade DCA, utilizando o coeficiente de Hill, aplicada à matriz de dados padronizados com os valores de cobertura para as espécies com três ou mais ocorrências amostradas nas parcelas de 1 x $1 \mathrm{~m}$ nos afloramentos rochosos ferruginosos na Fazenda São Sebastião do Carandá, em Ladário, MS. 


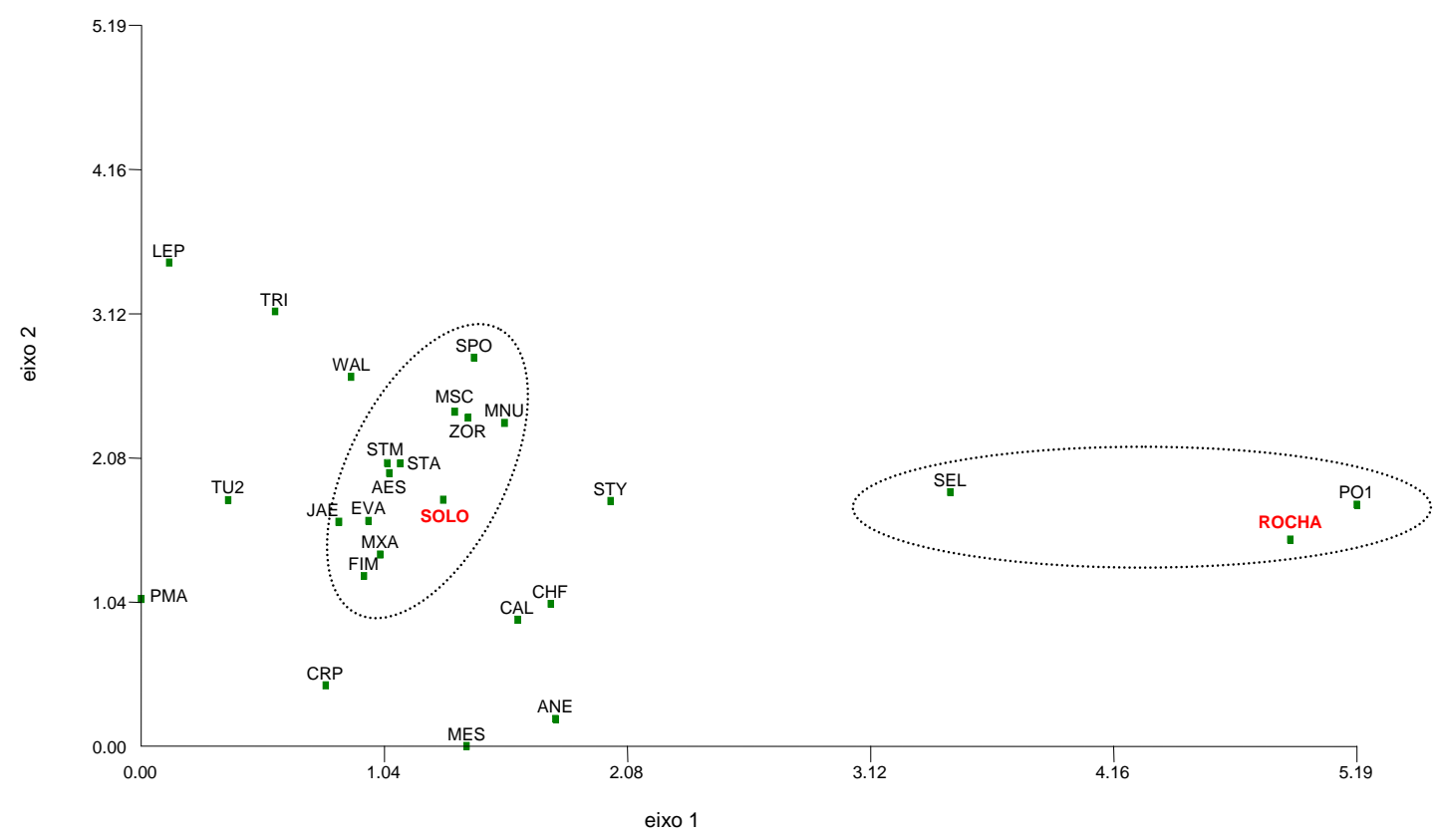

Figura 21 - Interpolação dos valores obtidos pela análise de correspondência modalidade DCA, utilizando o coeficiente de Hill, aplicada à matriz de dados padronizados com os valores de cobertura para as espécies com três ou mais ocorrências amostradas nas parcelas de $1 \times 1 \mathrm{~m}$ nos afloramentos rochosos ferruginosos na Fazenda São Sebastião do Carandá, em Ladário, MS. As elipses representam espécies associadas a uma maior proporção de solo exposto ou substrato rochoso (ver texto para maiores detalhes). As abreviaturas para os nomes das espécies constam no Anexo 2 . 


\section{- Fazenda Monjolinho}

A análise de ordenação de coordenadas principais (PCO) para a matriz com dados de cobertura de 29 espécies (aquelas com três ou mais ocorrências) nas 58 parcelas de 1 x 1 m mostrou que o eixo 1 explicou 10,9\% da variação dos dados enquanto o eixo 2 explicou 8,9\%, perfazendo um total de 19,8\% de informação da matriz.

A interpolação entre os eixos 1 e 2 do PCO e as correlações de Pearson revelaram um gradiente ambiental com parcelas com maior proporção de rocha exposta $(\mathrm{r}=0,476)$ e presença das espécies: Selaginella sellowii $(\mathrm{r}=0,427)$ e Polycarpaea corymbosa $(\mathrm{r}=0,372)$ concentrando-se no lado positivo do eixo 1 (Figura 22). Por sua vez, o lado negativo do mesmo eixo foi definido pelas parcelas com maior proporção de pedras soltas $(\mathrm{r}=-0,546)$ e a ocorrência das espécies Mimosa $n u d a(\mathrm{r}=-$ $0,678)$ e Mesosetum chaseae $(\mathrm{r}=-0,490)$. O gradiente ambiental revelado pelo eixo 2 da PCO foi definido pelas parcelas com presença das gramíneas Microchloa indica $(\mathrm{r}=-0,602)$ e Mesosetum chaseae $(\mathrm{r}=-0,471)$ em contraposição às parcelas com a ocorrência da pteridófita Selaginella sellowii (r=-0,627). 


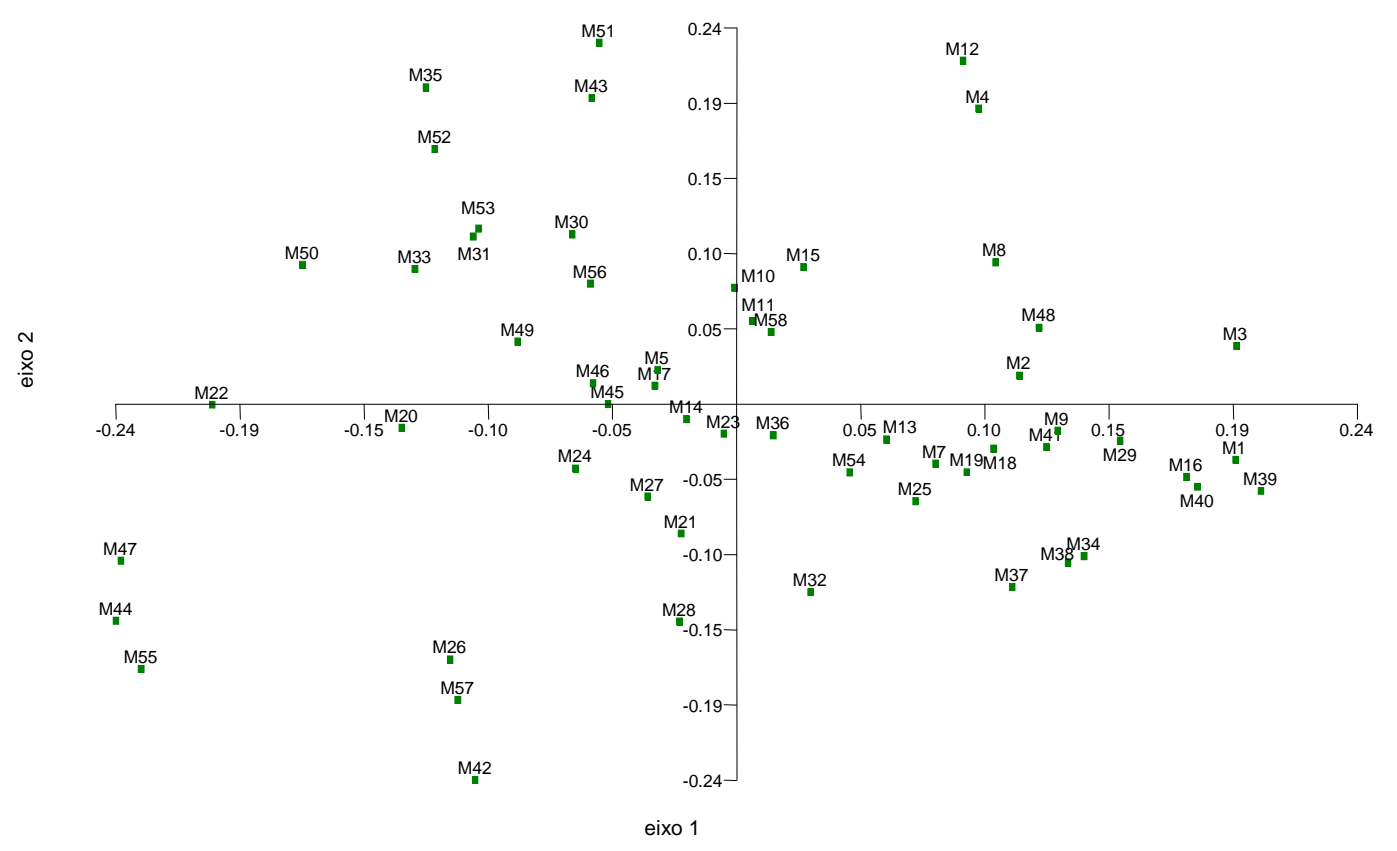

Figura 22 - Interpolação de escores de espécies dos dois primeiros eixos resultantes da análise de coordenadas principais (PCO), utilizando o coeficiente de distância de Gower, aplicada à matriz de dados padronizados com os valores de cobertura para as espécies com três ou mais ocorrências amostradas nas parcelas de $1 \times 1 \mathrm{~m}$ nos afloramentos rochosos ferruginosos na Fazenda Monjolinho, em Corumbá, MS.

A análise de correspondência destendencionada (DCA) para a matriz com dados de cobertura de 29 espécies (aquelas com duas ou mais ocorrências) nas 58 parcelas de 1 x 1 m produziu um arranjo onde o eixo 1 explicou 12,1\% da variação dos dados enquanto o eixo 2 explicou $8,4 \%$, perfazendo um total de $20,5 \%$ de informação da matriz.

A interpolação entre os eixos 1 e 2 da DCA mostrou o gradiente ambiental entre as parcelas com maior proporção de rocha exposta no lado direito do eixo 1 
associadas à presença de Polycarpaea corymbosa e Cyperus cornelli-oostenii (Figura 23). Este local revelou uma associação diferente em relação aos outros sítios estudados pois as espécies Selaginella sellowii e Portulaca sp1 estiveram relacionadas às parcelas com maior proporção de solo exposto e a espécie Discocactus ferricola às parcelas com maior proporção de pedras soltas (Figuras $23 \mathrm{e}$ 24).

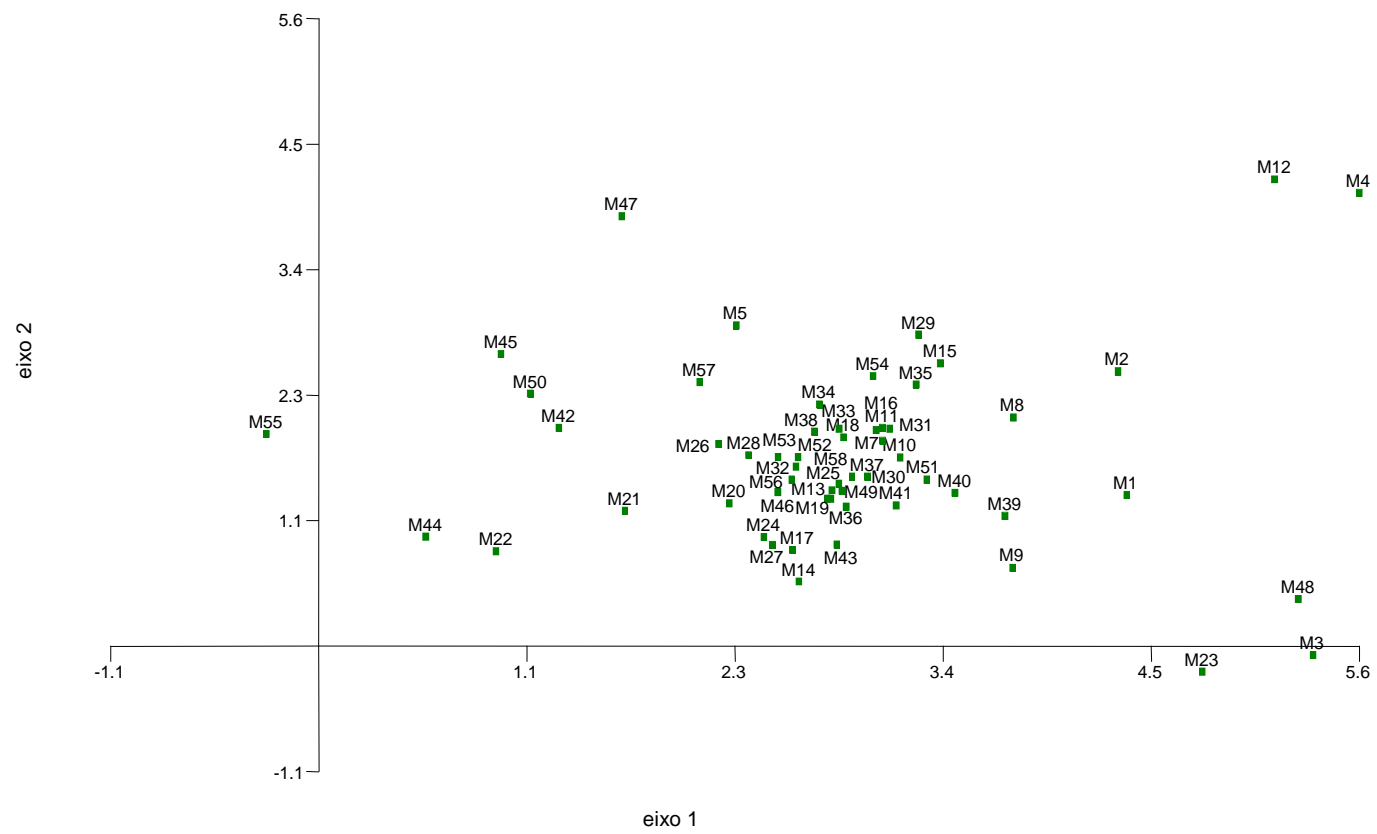

Figura 23 - Interpolação de escores de parcelas dos dois primeiros eixos resultantes da análise de correspondência modalidade DCA, utilizando o coeficiente de Hill, aplicada à matriz de dados padronizados com os valores de cobertura para as espécies com três ou mais ocorrências amostradas nas parcelas de $1 \times 1 \mathrm{~m}$ nos afloramentos rochosos ferruginosos na Fazenda Monjolinho, em Corumbá, MS. 


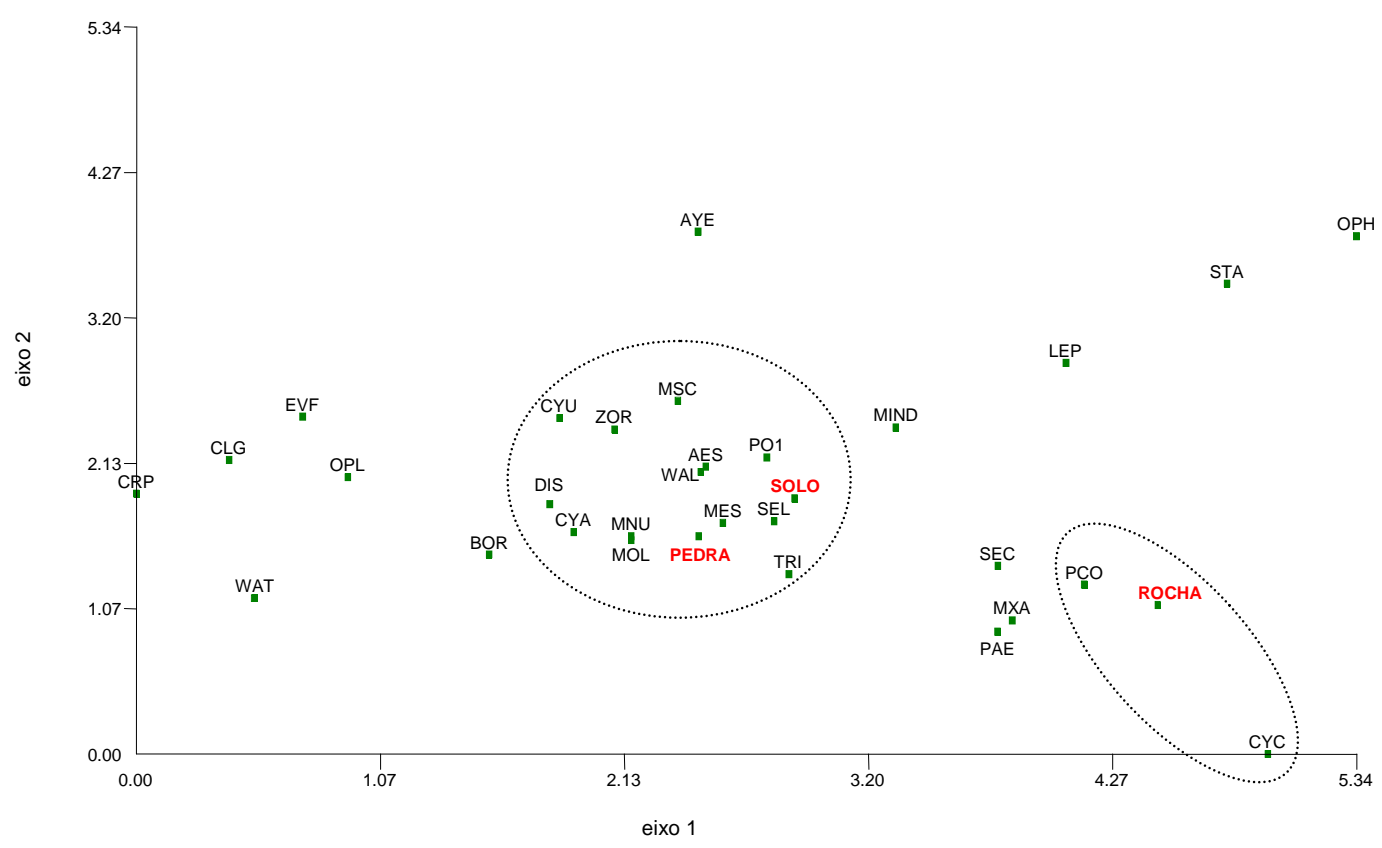

Figura 24 - Interpolação dos valores obtidos pela análise de correspondência modalidade DCA, utilizando o coeficiente de Hill, aplicada à matriz de dados padronizados com os valores de cobertura para as espécies com três ou mais ocorrências amostradas nas parcelas de $1 \times 1 \mathrm{~m}$ nos afloramentos rochosos ferruginosos na Fazenda Monjolinho, em Corumbá, MS. As elipses representam espécies associadas a uma maior proporção de solo e pedras soltas além de outro grupo com maior proporção de substrato rochoso (ver texto para maiores detalhes). As abreviaturas para os nomes das espécies constam no Anexo 2 . 


\section{Estrutura da vegetação em ilhas de solo}

A área total de 164 ilhas de solo amostradas nas bancadas lateríticas foi de $6206 \mathrm{~m}^{2}$ sendo registradas 181 espécies pertencentes a 58 famílias botânicas e mais dois táxons não identificados. Deste total, foram observadas oito espécies de pteridófitas pertencentes a cinco famílias. As famílias com maior número de espécies foram: Fabaceae e Poaceae (19), Malvaceae (13), Euphorbiaceae (9) e Cyperaceae e Apocynaceae (7). Os parâmetros fitossociológicos constam no Anexo 1.

As dez espécies com maiores valores de freqüência relativa perfizeram um total de 31,7\%: Selaginella sellowii (4,8\%), Mimosa xanthocentra e Deuterocohnia meziana (4\%), Staelia sp. (3,6\%), Anemia tomentosa (3\%), Sporobulus monandrus $(2,7 \%)$, Calea elongata (2,5\%), Bromelia balansae, Tripogon spicatus e Aeschynomene histrix (2,4\%) (Anexo 1 e Figura 25).

As dez espécies que apresentaram os maiores valores de dominância relativa foram componentes arbustivos-arbóreos, com exceção da pteridófita Selaginella sellowii, perfazendo 58,8\%. As duas espécies com os maiores valores de dominância relativa foram Bromelia balansae (24\%) e Deuterocohnia meziana (10,4\%), e as oito espécies mais importantes apresentaram, cada uma, valores inferiores a 5\%: Astronium fraxinifolium, Commiphora leptophloeos, Mimosa xanthocentra, Selaginella sellowii, Tabebuia impetiginosa, Tocoyena formosa, Jacaranda cuspidifolia e Amburana cearensis (Anexo 1 e Figura 9). 


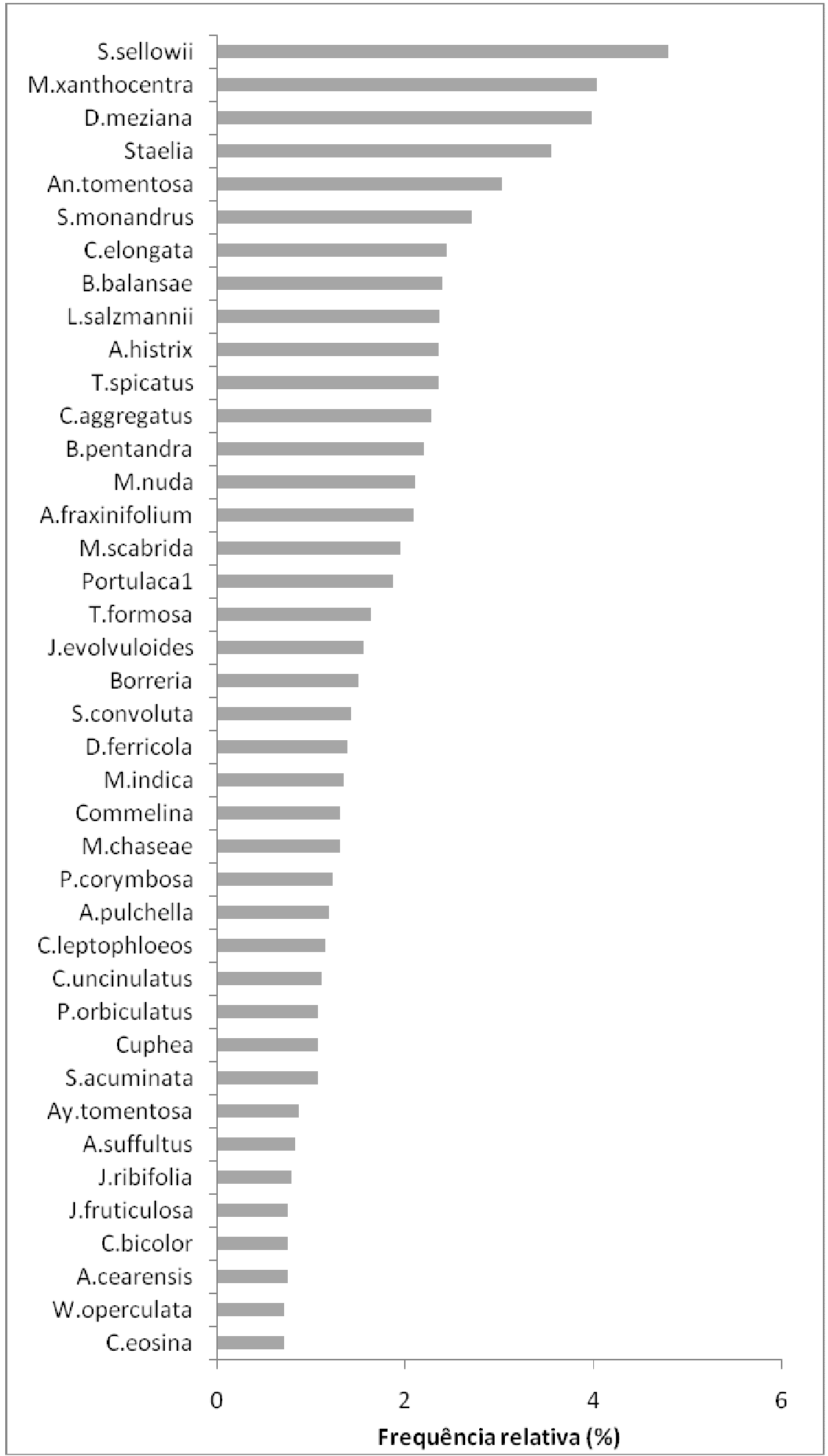

Figura 25 - As quarenta espécies com maiores valores de frequência relativa, em porcentagem, amostradas em ilhas de solo $(n=164)$ em afloramentos rochosos ferruginosos em Corumbá, MS. Para o nome completo das espécies consultar a Anexo 1. 
As ilhas de solo podem ser caracterizadas pela presença de Bromelia balansae e de Deuterocohnia meziana (Bromeliaceae), as duas espécies com os maiores valores de importância observados (Anexo 1 e Figura 10). A pteridófita Selaginella sellowii também foi um elemento importante para a composição da vegetação que ocorre em ilhas de solo. As dez espécies em ilha de solo com maiores valores de importância foram: Bromelia balansae (13,2\%), seguida por Deuterocohnia meziana $(7,1 \%)$, Selaginella sellowii (3,8\%), Astronium fraxinifolium (3,6\%) e Mimosa xanthocentra (3,6\%), Staelia sp. (2,8\%), Commiphora leptophloeos (2,6\%), Anemia tomentosa $(2,4 \%)$, Sporobulus monandrus $(2,3 \%)$ e Tocoyena formosa $(2 \%)$, perfazendo $43,4 \%$ do total de VI.

As curvas de rarefação ou curva acumulativa de espécies para a vegetação em ilhas de solo das Fazendas Monjolinho e Banda Alta apresentaram uma estabilização aparente ao nível de 95\% enquanto os dados para a Fazenda São Sebastião do Carandá não mostraram esta estabilização (Figura 26). 
A

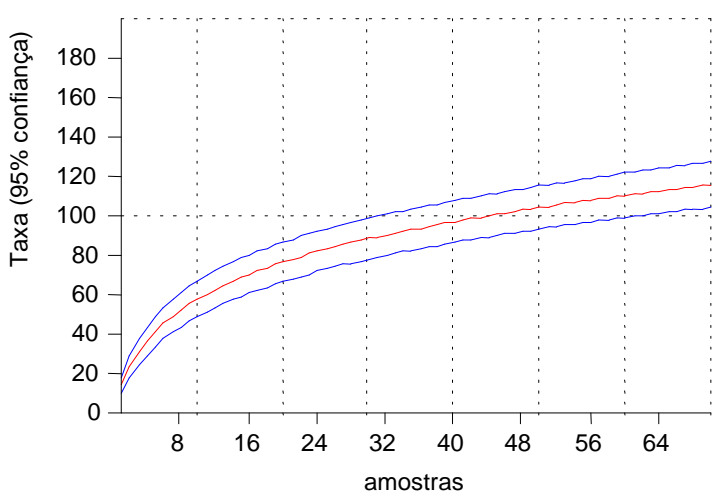

B

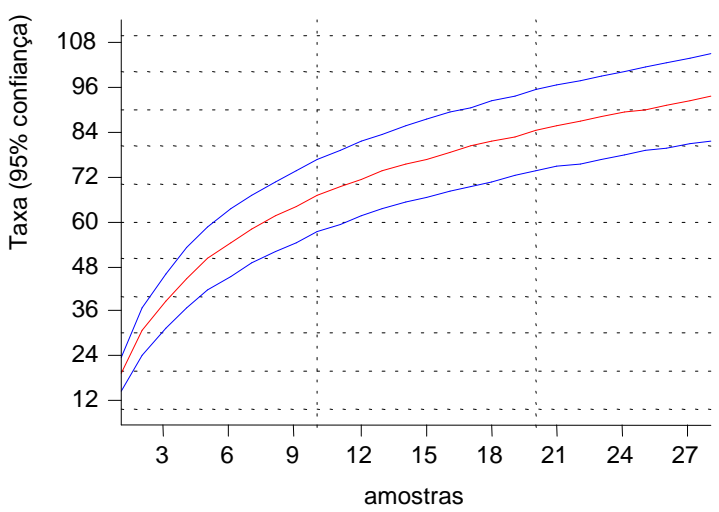

C

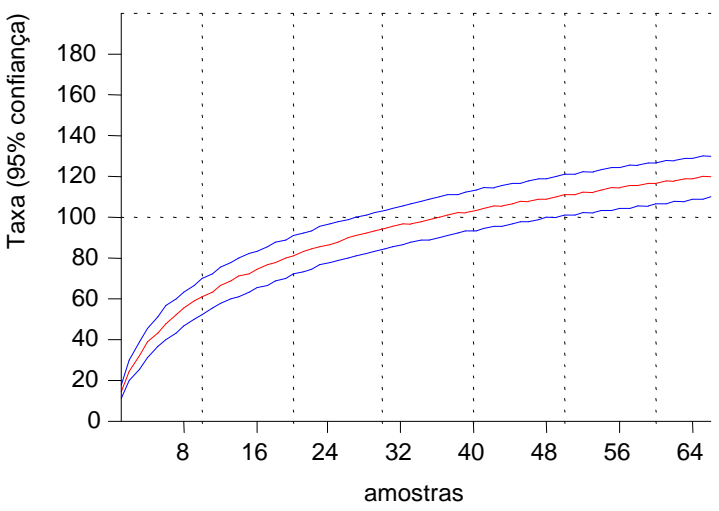

Figura 26 - Curvas de número acumulativo de espécies vasculares amostradas em ilhas de solo baseadas em reamostragem aleatória (linha central) e intervalos de confiança de 95\% (linhas superior e inferior) para as espécies amostradas em afloramentos rochosos ferruginosos em Corumbá, MS. A=Fazenda Banda Alta, B=Fazenda São Sebastião do Carandá, C=Fazenda Monjolinho. 
O maior valor do índice de diversidade de Shannon para as comunidades amostradas nas ilhas de solo foi constatado para a Fazenda S.Sebastião do Carandá, seguida pela Fazenda Monjolinho e Banda Alta (Tabela 3). O índice de equabilidade para a comunidade insular da Fazenda São Sebastião do Carandá foi superior às outras áreas (Tabela 3).

Tabela 3 - Valores dos índices de diversidade de Shannon $\left(\mathrm{H}^{\prime}\right)$, expressos em nats/indivíduos, e de equabilidade de Pielou (J) calculados para a vegetação em ilhas de solo amostrada em três afloramentos rochosos ferruginosos em Corumbá, MS.

\begin{tabular}{lll}
\hline Local & $\mathrm{H}^{\prime}$ (nats/indivíduos) & $\mathrm{J}$ \\
\hline Fazenda Banda Alta & 3,0654 & 0,6448 \\
Fazenda São Sebastião do Carandá & 3,2669 & 0,7207 \\
Fazenda Monjolinho & 3,1652 & 0,6611 \\
\hline
\end{tabular}

\section{Formas de vida}

As formas de vida predominantes nas ilhas de solo foram nanofanerófitas (44 espécies), seguidas por hemicriptófitas (37), microfanerófitas (36), lianas (27), caméfitas (19), terófitas (18), suculentas (5), epífitas e geófitas (2) (Figura 27).

Quando o espectro biológico foi comparado à normal de Raunkiaer verificou-se que as fanerófitas foram componentes mais importantes do que as hemicriptófitas devido ao número elevado de espécies arbustivo-arbóreas amostradas nas ilhas de solo da Fazenda São Sebastião do Carandá (Figura 27). 
As Fazendas Banda Alta e Monjolinho apresentaram um espectro biológico bastante semelhante à normal de Raunkiaer com o predomínio de hemicriptófitas seguidas por nano e microfanerófitas (Figura 28).

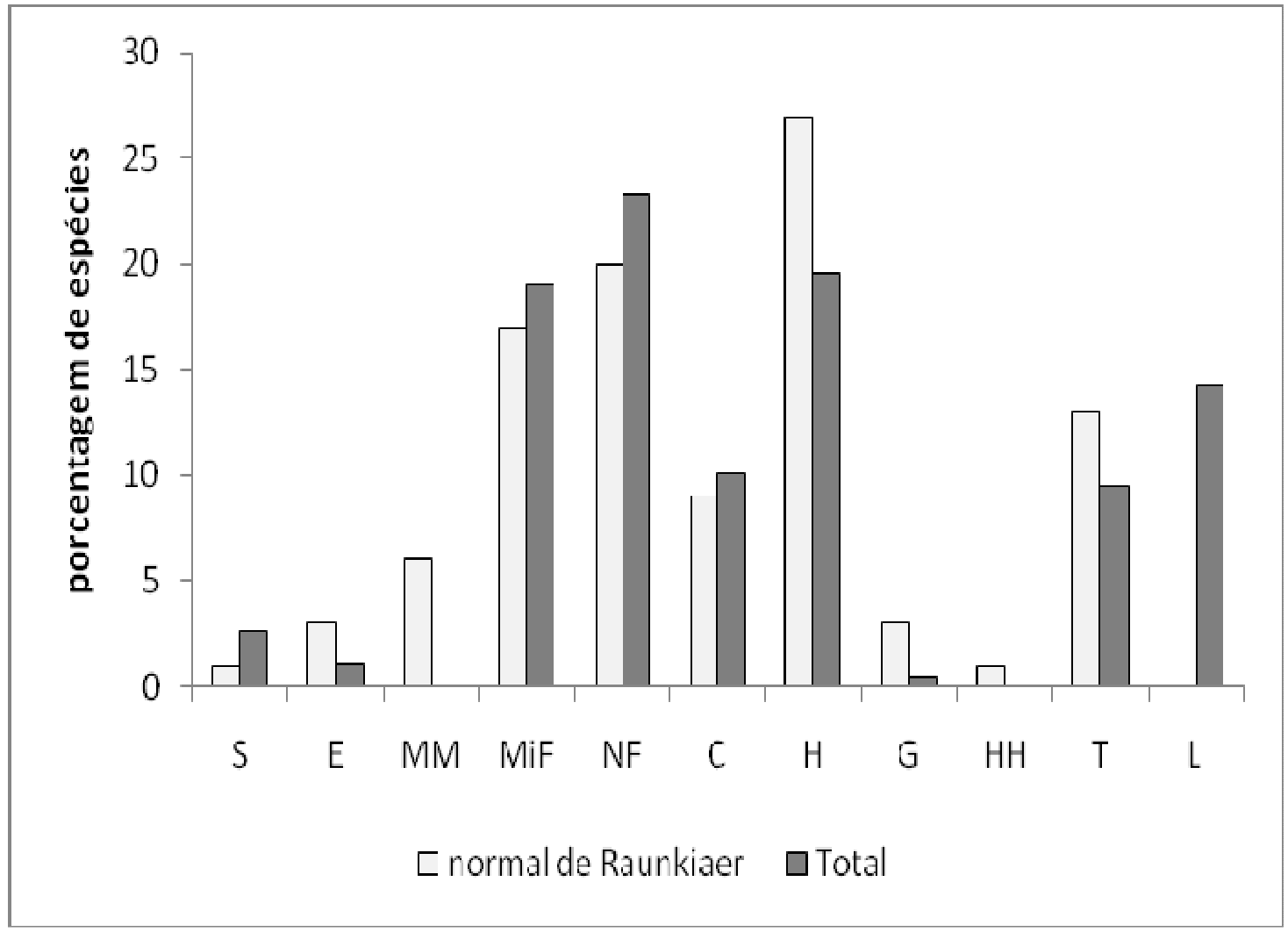

Figura 27 - Espectro biológico do total de espécies encontradas nas ilhas de solo dos afloramentos rochosos ferruginosos de Corumbá, MS, comparado à proporção normal de Raunkiaer. S=suculenta, E=epífita, MM=mega e mesofanerófita, MiF=microfanerófita, $\quad \mathrm{NF}=$ nanofanerófita,$\quad \mathrm{C}=$ caméfita, $\mathrm{H}=$ hemicriptófita, $\mathrm{G}=$ geófita, $\mathrm{HH}=$ hidrófita, $\mathrm{T}=$ =terófita, L=liana. 


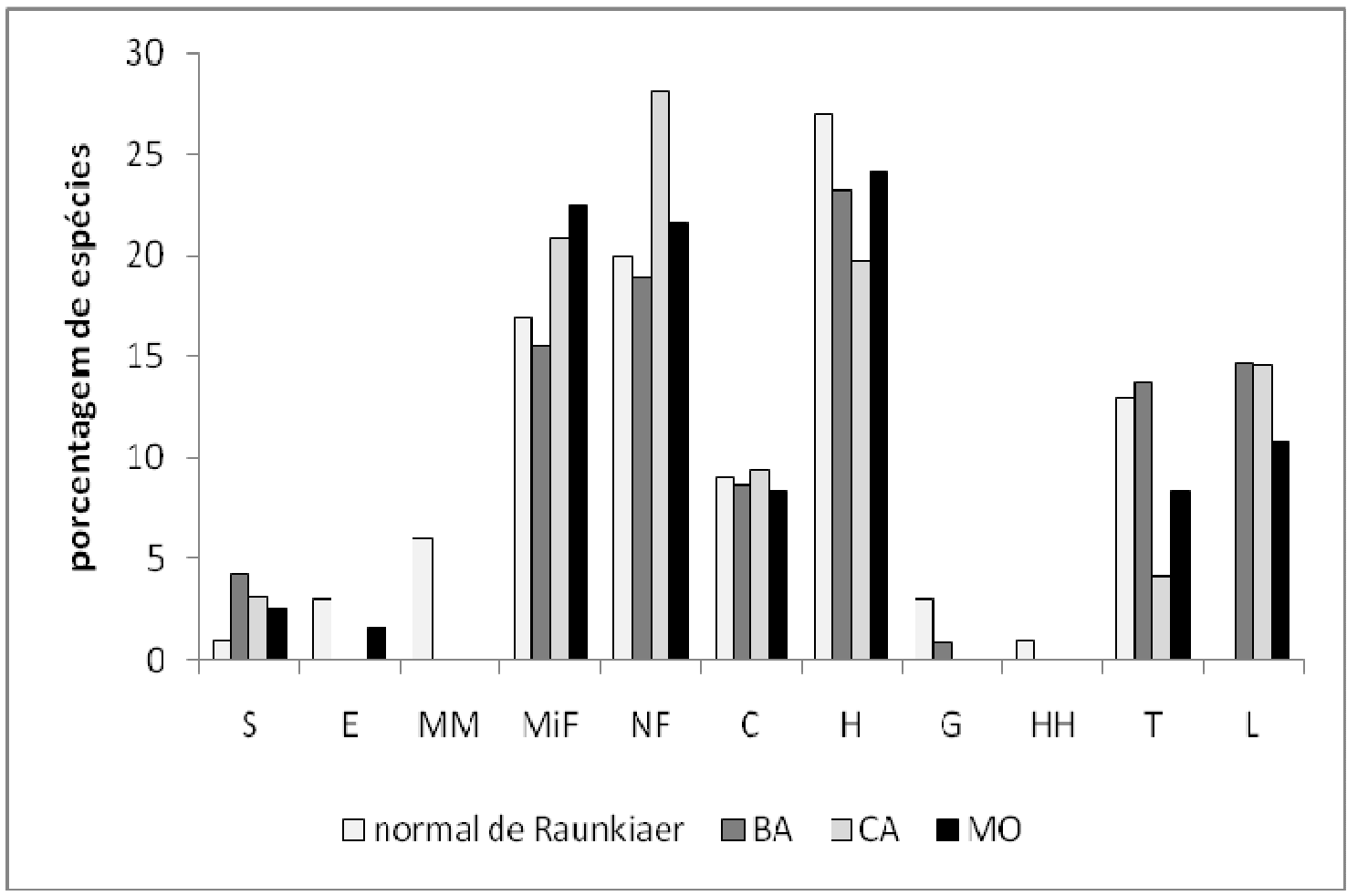

Figura 28 - Espectro biológico do total de espécies encontradas nas ilhas de solo dos três afloramentos rochosos ferruginosos de Corumbá, MS, comparado à proporção normal de Raunkiaer. BA=Fazenda Banda Alta, CA=Fazenda São Sebastião do Carandá, $\mathrm{MO}=$ Fazenda Monjolinho. Os nomes das classes seguem a mesma da Figura 27.

O desenho esquemático representou uma ilha de solo com Deuterocohnia meziana associada a um elemento arbóreo Astronium fraxinifolium na Fazenda Banda Alta (Figura 29). A ocorrência de moitas monoespecíficas de Deuterocohnia meziana (ou associação desta com algumas poucas espécies predominantemente herbáceas) determina a fisionomia dos lajedos de Corumbá. Entretanto, ilhas de solo com esta espécie de bromélia não ocorreram na Fazenda São Sebastião do Carandá provavelmente pela baixa proporção de rocha exposta neste afloramento e a baixa declividade que permitiu o depósito de uma fina camada de substrato por quase a totalidade de sua área. 


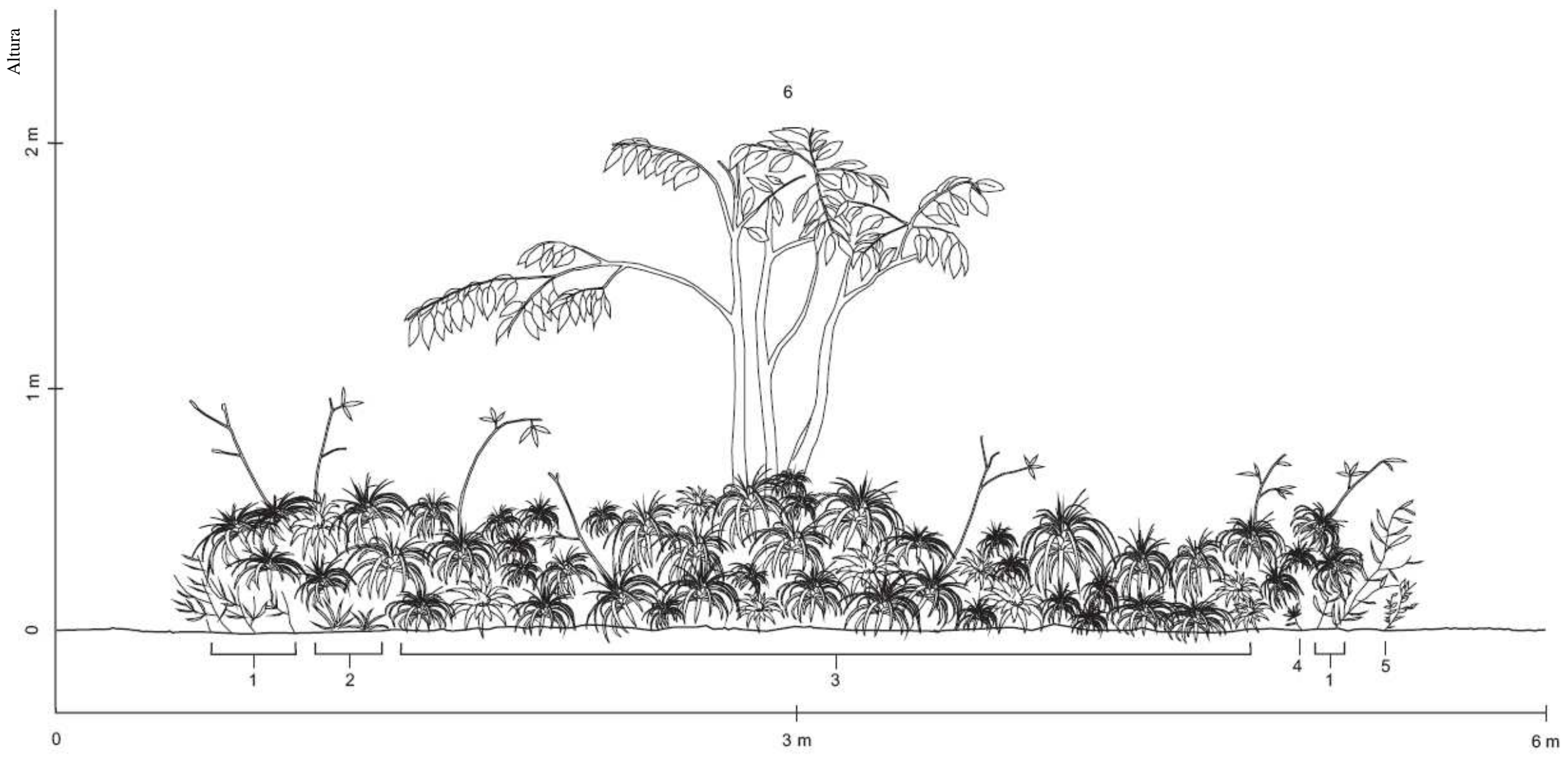


Figura 29 - Desenho esquemático da vegetação em perfil correspondente a um trecho de 2 x 10m (representou-se $6 \mathrm{~m}$ nesta figura pois o restante do trecho correspondeu à rocha nua) de uma ilha de solo arbustiva com Deuterocohnia meziana e a arbórea Astronium fraxinifolium, na Fazenda Banda Alta, Ladário, MS. O código das espécies utilizado foi: 1=Staelia sp., 2=Microchcloa indica, 3= Deuterocohnia meziana, 4=Portulaca sp1, 5=Polycarpaea corymbosa, 6= Astronium fraxinifolium. 


\section{Análises de Ordenação para a vegetação amostrada em ilhas de solo}

\section{- Fazenda Banda Alta}

A análise de ordenação de coordenadas principais (PCO) para a matriz com dados de cobertura de 66 espécies (com três ou mais ocorrências) nas 70 ilhas de solo mostrou que o eixo 1 explicou 12,4\% da variação dos dados enquanto o eixo 2 explicou 5,9\%, perfazendo um total de 18,3\% de informação da matriz.

A interpolação entre os eixos 1 e 2 da PCO revelou um gradiente longo para as maiores unidades insulares da Fazenda Banda Alta no lado direito do eixo 1 com a polarização entre as ilhas com Bromelia balansae no lado direito do eixo 1 e as ilhas com Deuterocohnia meziana no lado oposto (Figura 30). O arranjo apresentado no gradiente revelado pela análise de $\mathrm{PCO}$ e as correlações de Pearson identificaram uma polarização entre as ilhas de solo com ocorrência das espécies: Commelina sp. $(\mathrm{r}=0,730)$, Bromelia balansae $(\mathrm{r}=0,687)$ e Anemia tomentosa $(\mathrm{r}=0,636)$ no lado positivo do eixo 1 e as ilhas de solo com Deuterocohnia meziana $(\mathrm{r}=-0,823)$. $\mathrm{O}$ arranjo apresentado no gradiente ao longo do eixo 2 da PCO foi determinado pela presença das espécies Cleome guianensis $(\mathrm{r}=0,536)$ e Alysicarpus vaginalis $(\mathrm{r}=0,492)$ em contraposição à ilhas de solo com Corchorus hirtus $(\mathrm{r}=-0,496)$. 


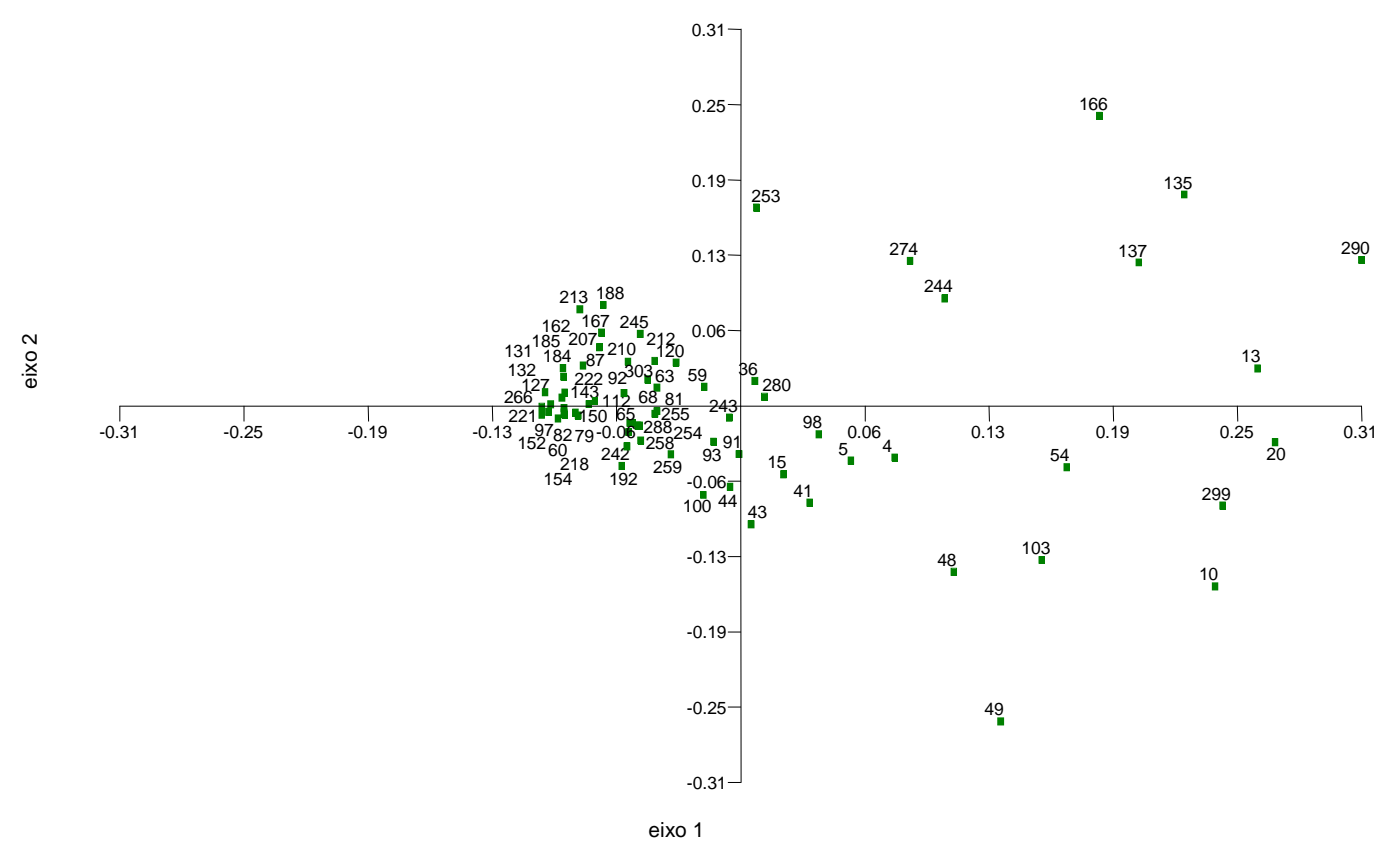

Figura 30 - Interpolação de escores das espécies dos dois primeiros eixos resultantes da análise de coordenadas principais (PCO), utilizando o coeficiente de distância de Gower, aplicada à matriz de dados padronizados com os valores de cobertura para as espécies com três ou mais ocorrências amostradas nas 70 ilhas de solo nos afloramentos rochosos ferruginosos na Fazenda Banda Alta, em Ladário, MS.

A análise de correspondência destendencionada (DCA) para a matriz com dados de cobertura de 66 espécies (aquelas com duas ou mais ocorrências) nas 70 ilhas de solo mostrou que o eixo 1 explicou 8,2\% da variação dos dados enquanto o eixo 2 explicou 6,1\%, perfazendo um total de 14,3\% de informação da matriz.

A interpolação entre os eixos 1 e 2 da DCA evidenciou a tendência identificada na análise anterior, entre as ilhas de solo com Deuterocohnia meziana e as ilhas com Bromelia balansae (Figura 31). A Figura 32 mostra um pequeno grupo de ilhas no lado direito do eixo 1 com espécies que ocorrem preferencialmente em 
locais com maior proporção de rocha exposta: Gomphrena centrota, Polycarpaea corymbosa e Staelia sp. Também foi possível verificar um grupo de ilhas de solo com Bromelia balansae, que atingem os maiores tamanhos insulares, associadas a elementos arbustivos-arbóreos no lado esquerdo do eixo 1 (Figura 32). As ilhas de solo com Deuterocohnia meziana estiveram associadas aos componentes herbáceos Selaginella sellowii e Discocactus ferricola (Figura 32).

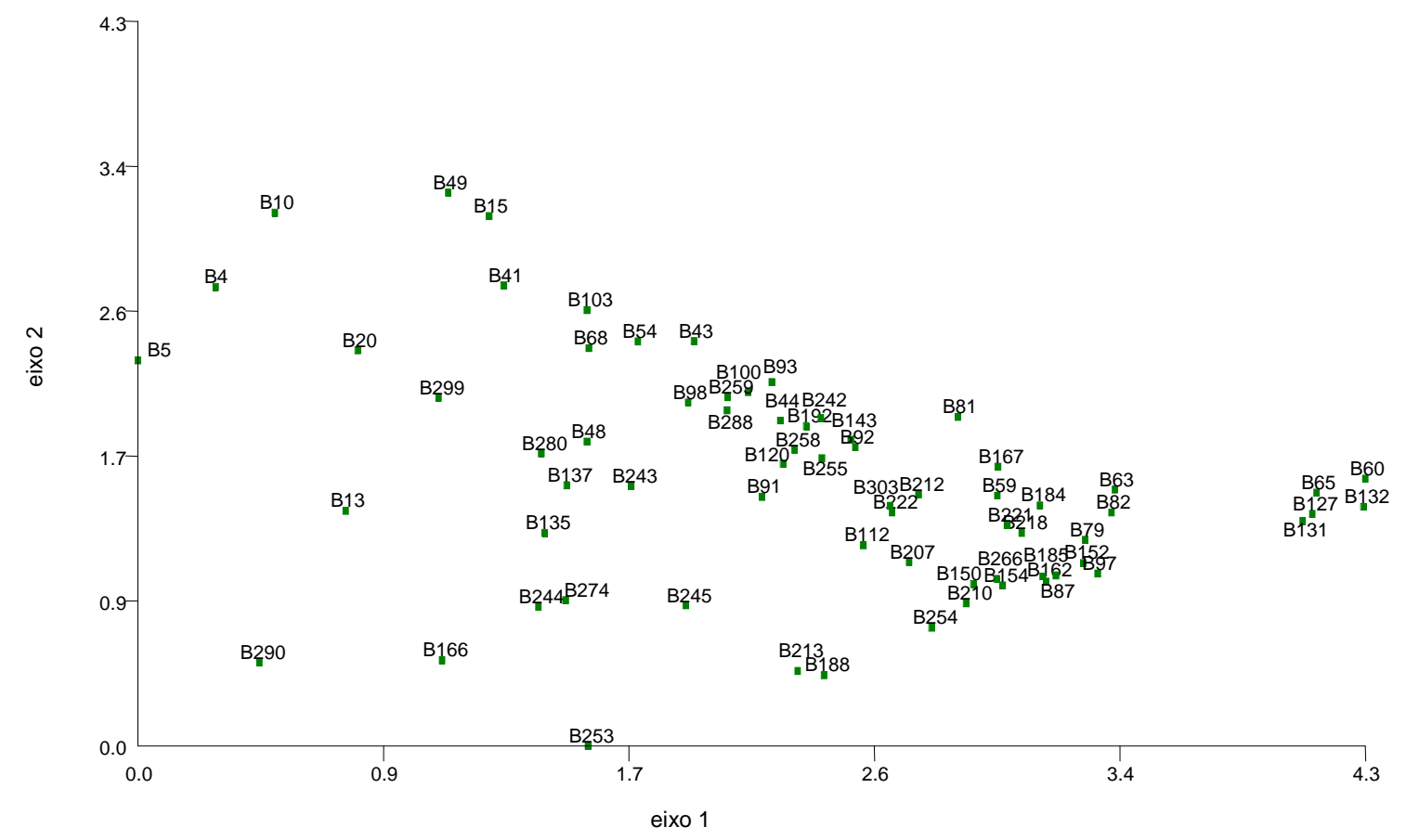

Figura 31 - Interpolação de escores das ilhas de solo dos dois primeiros eixos resultantes da análise de correspondência modalidade DCA, utilizando o coeficiente de Hill, aplicada à matriz de dados padronizados com os valores de cobertura para as espécies com três ou mais ocorrências amostradas nas ilhas de solo nos afloramentos rochosos ferruginosos na Fazenda Banda Alta, em Ladário, MS. 


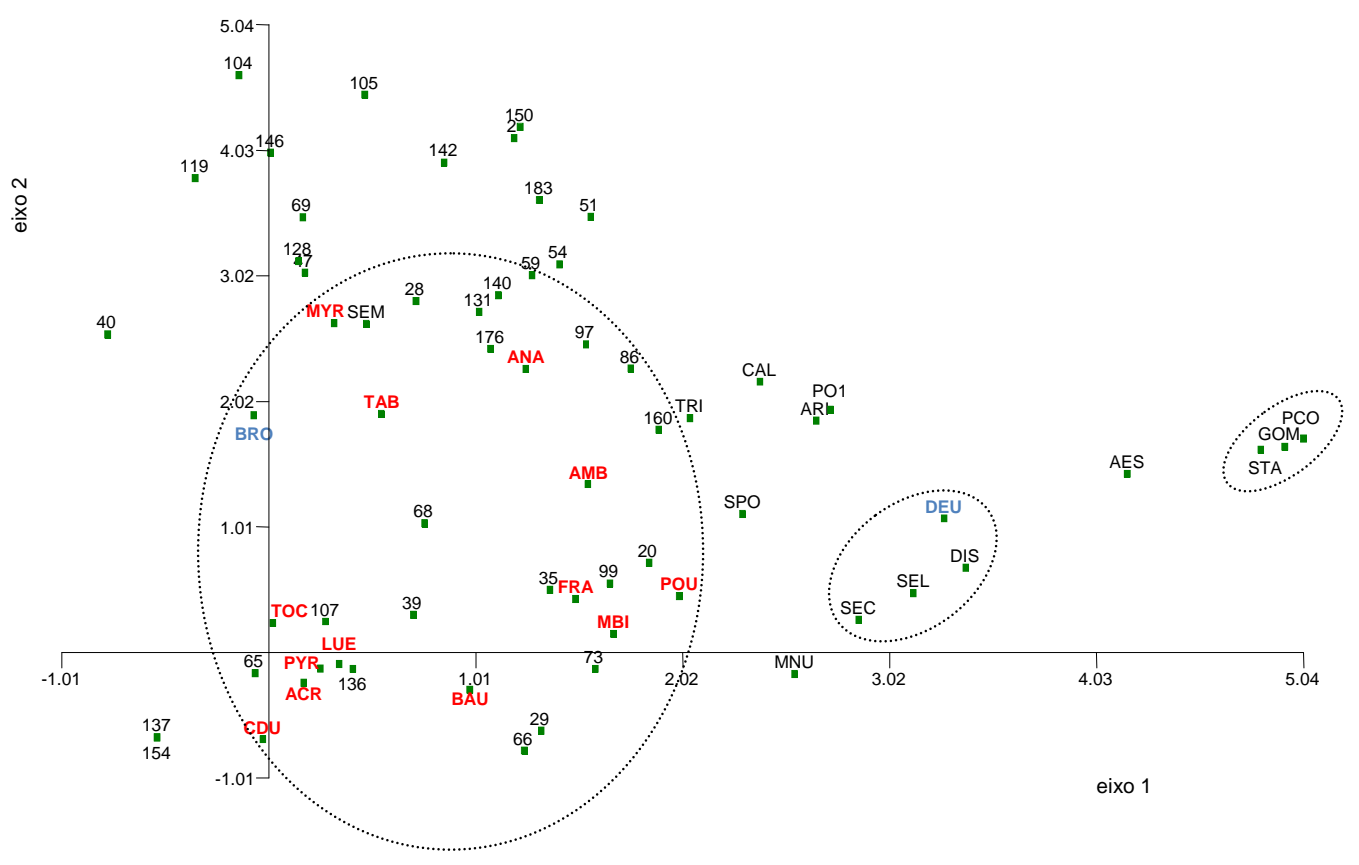

Figura 32 - Interpolação dos valores obtidos pela análise de correspondência modalidade DCA, utilizando o coeficiente de Hill, aplicada à matriz de dados padronizados com os valores de cobertura para as espécies com três ou mais ocorrências amostradas nas ilhas de solo dos afloramentos rochosos ferruginosos na Fazenda Banda Alta, em Ladário, MS. Foram representadas as espécies mais relevantes para a configuração do gradiente ambiental destacando-se os componentes arbustivo-arbóreos (em vermelho) e as espécies $\mathrm{BRO}=$ Bromelia balansae e DEU=Deuterocohnia meziana (em azul escuro). As elipses representam: o grupo de espécies predominantemente arbustivo-arbóreas relacionadas à Bromelia balansae, o grupo de espécies herbáceas associadas à Deuterocohnia meziana e finalmente, ao grupo de espécies estabelecida em locais com maior proporção de rocha (ver texto para maiores detalhes). As abreviaturas utilizadas constam no Anexo 2. 


\section{- Fazenda São Sebastião do Carandá}

A análise de ordenação de coordenadas principais (PCO) para a matriz com dados de cobertura de 57 espécies (com três ou ocorrências) nas 28 ilhas de solo mostrou que o eixo 1 explicou 12,9\% da variação dos dados enquanto o eixo 2 explicou $11,1 \%$, perfazendo um total de $24 \%$ de informação da matriz.

A interpolação entre os eixos 1 e 2 da PCO e as análises de correlação de Pearson sugerem que os arranjos do gradiente foi determinado pela presença da ciperácea Cyperus subcastaneus $(\mathrm{r}=0,888)$ e de componentes arbustivo-arbóreos como Bredemeyera floribunda $(\mathrm{r}=0,859)$, Tocoyena formosa $(\mathrm{r}=0,781)$ e Guibourtia hymenaefolia $(\mathrm{r}=0,735)$ no lado positivo do eixo 1 (Figura 33). O lado negativo do eixo 1 foi definido pela presença de componentes herbáceos Microtea scabrida (r=0,402), Aeschnomene histrix ( $\mathrm{r}=-0,372)$ e da bromeliácea Bromelia balansae $(\mathrm{r}=-0,345)$. O arranjo revelado pela distribuição das ilhas de solo ao longo do eixo 2 da PCO foi definido pela espécie arbórea Commiphora leptophloeos $(\mathrm{r}=0,751)$ e Bromelia balansae $(\mathrm{r}=0,636)$ em contraposição ao arbusto Aspicarpa pulchella $(\mathrm{r}=-0,454)$ e a pteridófita Anemia tomentosa $(\mathrm{r}=-0,445)$. Um pequeno grupo de ilhas de solo (C3, C4, C5 e C6) destaca-se das demais pela combinação de vários componentes arbustivos-arbóreos (Astronium fraxinifolium, Bauhinia pentandra, Bredemeyera floribunda, Erythroxylum deciduum, Pouteria sp., Praecereus euchlorus, Tocoyena formosa) (Figura 33). 


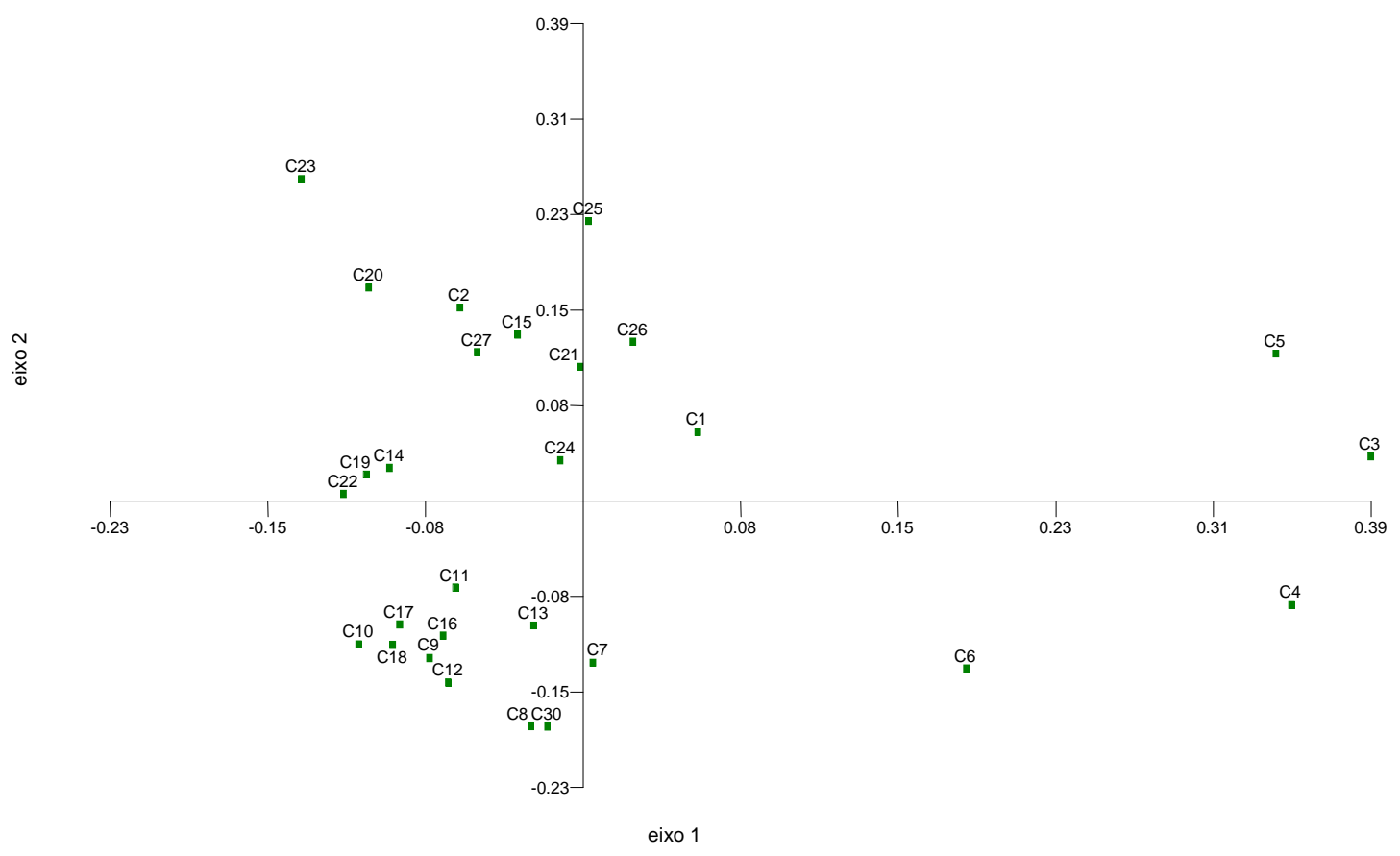

Figura 33 - Interpolação de escores de espécies dos dois primeiros eixos resultantes da análise de coordenadas principais (PCO), utilizando o coeficiente de distância de Gower, aplicada à matriz de dados padronizados com os valores de cobertura para as espécies com três ou mais ocorrências amostradas nas ilhas de solo nos afloramentos rochosos ferruginosos na Fazenda São Sebastião do Carandá, em Ladário, MS.

A análise de correspondência destendencionada (DCA) para a matriz com dados de cobertura de 57 espécies (aquelas com três ou mais ocorrências) nas 28 ilhas de solo mostrou que o eixo 1 explicou 12,1\% da variação dos dados enquanto o eixo 2 explicou 8,6\%, perfazendo um total de 20,7\% de informação da matriz.

A interpolação entre os eixos 1 e 2 da DCA mostrou um gradiente ambiental longo para as ilhas de solo onde as ilhas de solo com componentes arbustivos-arbóreos agruparam-se no lado esquerdo do eixo 1 enquanto as ilhas 
com espécies predominantemente herbáceas agruparam-se no lado direito do eixo (Figuras 34 e 35).

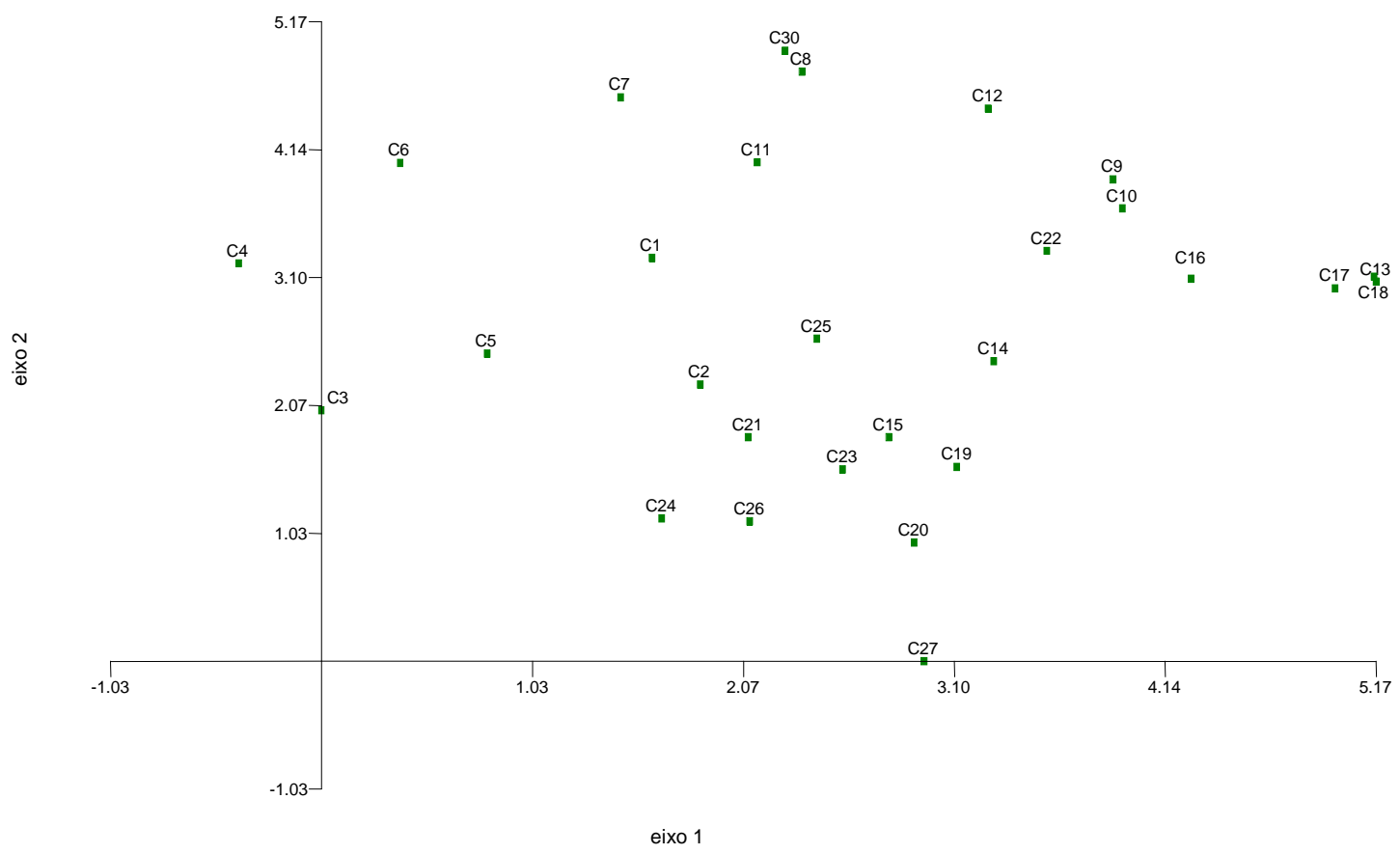

Figura 34 - Interpolação de escores de ilhas de solo dos dois primeiros eixos resultantes da análise de correspondência modalidade DCA, utilizando o coeficiente de Hill, aplicada à matriz de dados padronizados com os valores de cobertura para as espécies com três ou mais ocorrências amostradas nas ilhas de solo nos afloramentos rochosos ferruginosos na Fazenda São Sebastião do Carandá, em Ladário, MS. 


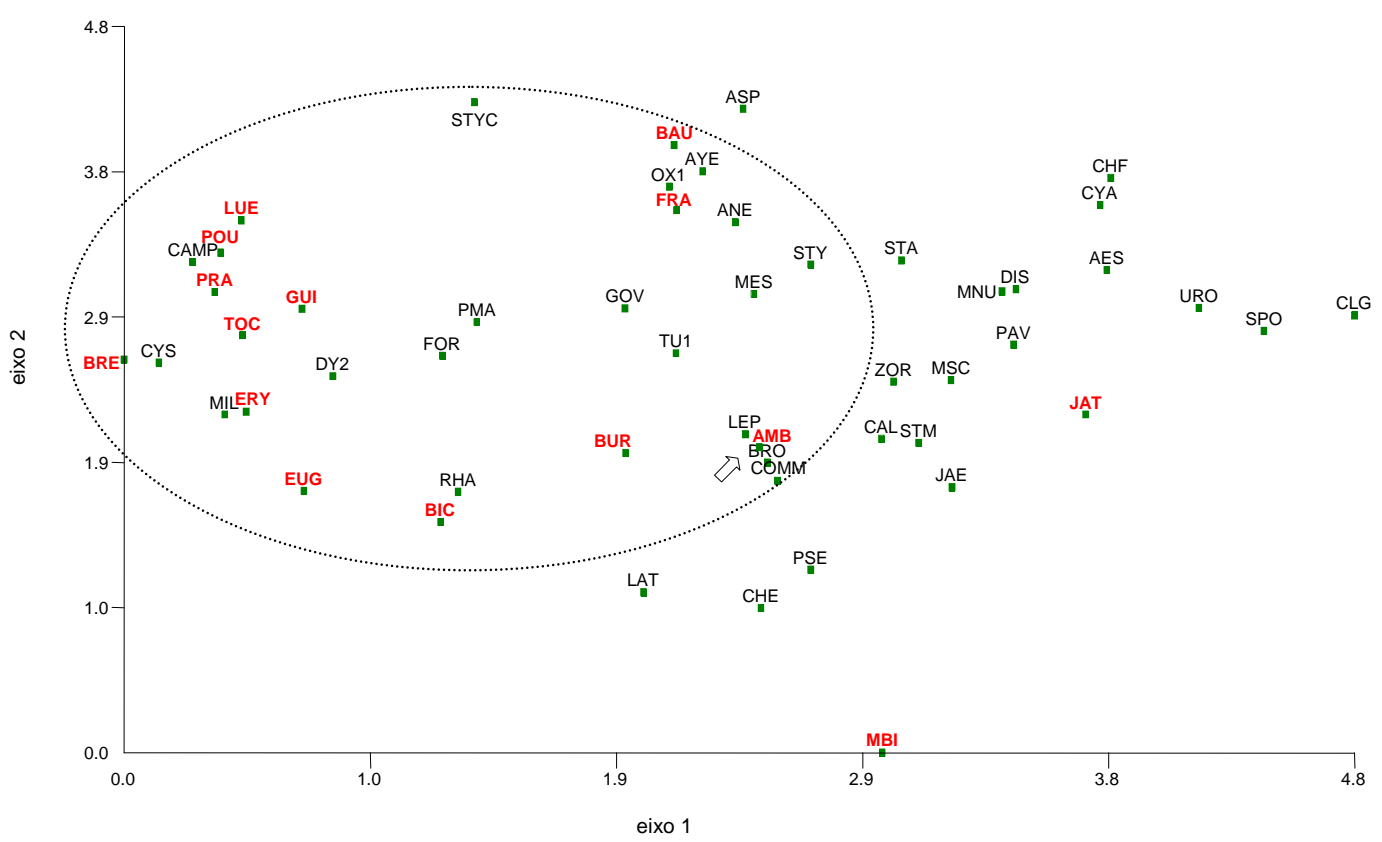

Figura 35 - Interpolação dos valores obtidos pela análise de correspondência modalidade DCA, utilizando o coeficiente de Hill, aplicada à matriz de dados padronizados com os valores de cobertura para as espécies com três ou mais ocorrências amostradas nas ilhas de solo dos afloramentos rochosos ferruginosos na Fazenda São Sebastião do Carandá, em Ladário, MS. Foram representadas em vermelho as espécies arbustivo-arbóreas e com uma seta a posição de Bromelia balansae dentro do gradiente ambiental. A elipse representa o grupo de espécies associadas à Bromelia balansae. As abreviaturas para os nomes das espécies constam no Anexo 2. 


\section{- Fazenda Monjolinho}

A análise de ordenação de coordenadas principais (PCO) para a matriz com dados de cobertura de 71 espécies (com três ou mais ocorrências) nas 66 ilhas de solo mostrou que o eixo 1 explicou 9,4\% da variação dos dados enquanto o eixo 2 explicou 7,2\%, perfazendo um total de 16,6\% de informação da matriz.

A interpolação entre os eixos 1 e 2 da $\mathrm{PCO}$ confirmou a polarização das ilhas com Deuterocohnia meziana no lado negativo do eixo 1 e as ilhas com Bromelia balansae no lado positivo do eixo que também coincide com os maiores tamanhos insulares, como constatado para as unidades insulares da Fazenda Banda Alta (Figura 36). O arranjo do gradiente revelado pelas análises de ordenação e as correlações de Pearson foi definido pela polarização de Bromelia balansae $(\mathrm{r}=0,666)$ e Deuterocohnia meziana $(\mathrm{r}=-0,882)$ ao longo do eixo 1 da PCO. A distribuição das ilhas de solo ao longo do eixo 2 da PCO foi definida pelas espécies Myrcia lauruotteana $(\mathrm{r}=0,399)$, Tocoyena formosa $(\mathrm{r}=0,335)$ e Ouratea aff. castaneifolia $(\mathrm{r}=0,333)$ em contraposição à Ayenia tomentosa $(\mathrm{r}=-0,798)$, Mesosetum chaseae $(\mathrm{r}=-0,649)$ e Anemia tomentosa $(\mathrm{r}=-0,624)$. 


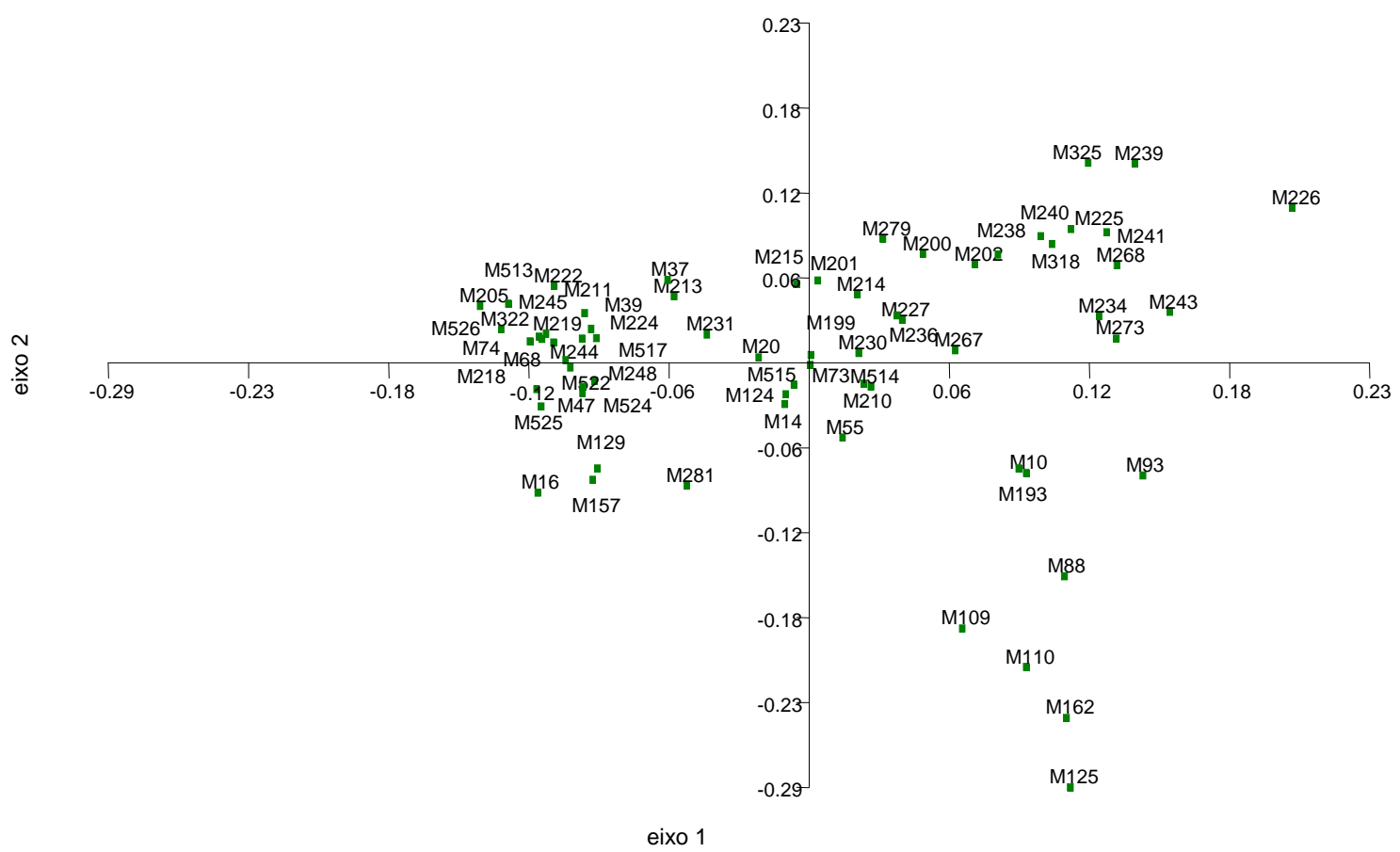

Figura 36 - Interpolação de escores de espécies dos dois primeiros eixos resultantes da análise de coordenadas principais (PCO), utilizando o coeficiente de distância de Gower, aplicada à matriz de dados padronizados com os valores de cobertura para as espécies com três ou mais ocorrências amostradas nas parcelas de $1 \times 1 \mathrm{~m}$ nos afloramentos rochosos ferruginosos na Fazenda Monjolinho, em Corumbá, MS.

A análise de correspondência destendencionada (DCA) para a matriz com dados de cobertura de 71 espécies (com três ou mais ocorrências) nas 66 ilhas de solo mostrou que o eixo 1 explicou 6,1\% da variação dos dados enquanto o eixo 2 explicou 4,5\%, perfazendo um total de 10,6\% de informação da matriz.

O arranjo do gradiente revelado pela interpolação entre os eixos 1 e 2 da DCA mostrou o gradiente ambiental formado pelas ilhas com Bromelia balansae associadas a diferentes espécies arbustivas-arbóreas no lado esquerdo do eixo 1 e, 
no lado oposto, as ilhas de solo com Deuterocohnia meziana, associadas predominantemente a componentes herbáceos, exceto as espécies arbustivoarbóreas Bauhinia pentandra e Talisisa esculenta (Figura 37). As Figuras 37 e 38 permitem observar um pequeno grupo de ilhas de solo com espécies arbustivoarbóreas como Ouratea aff. castanaefolia, Praecereus euchlorus e Psycotria sp. bem como outro grupo de ilhas de solo com espécies que conseguem se estabelecer diretamente na rocha ou com um substrato extremamente fino, como Discocactus ferricola, Microtea scabrida, Mollugo verticillata, Sporobulus monandrus, Tripogon spicatus, Waltheria operculata, Waltheria sp2 entre outras (Figura 38). 


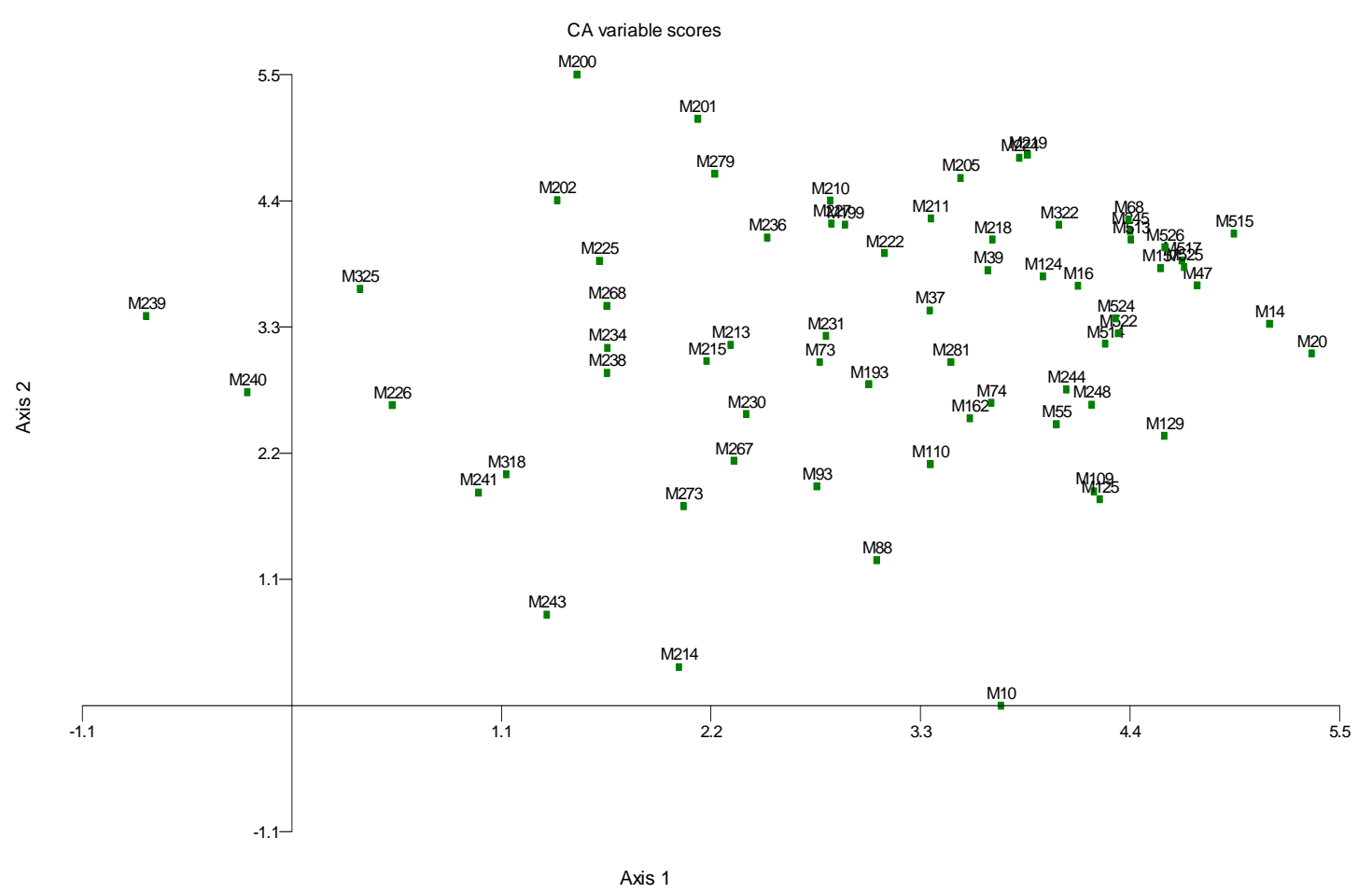

Figura 37 - Interpolação de escores de ilhas de solo dos dois primeiros eixos resultantes da análise de correspondência modalidade DCA, utilizando o coeficiente de Hill, aplicada à matriz de dados padronizados com os valores de cobertura para as espécies com três ou mais ocorrências amostradas nas ilhas de solo nos afloramentos rochosos ferruginosos na Fazenda Monjolinho, em Corumbá, MS. 


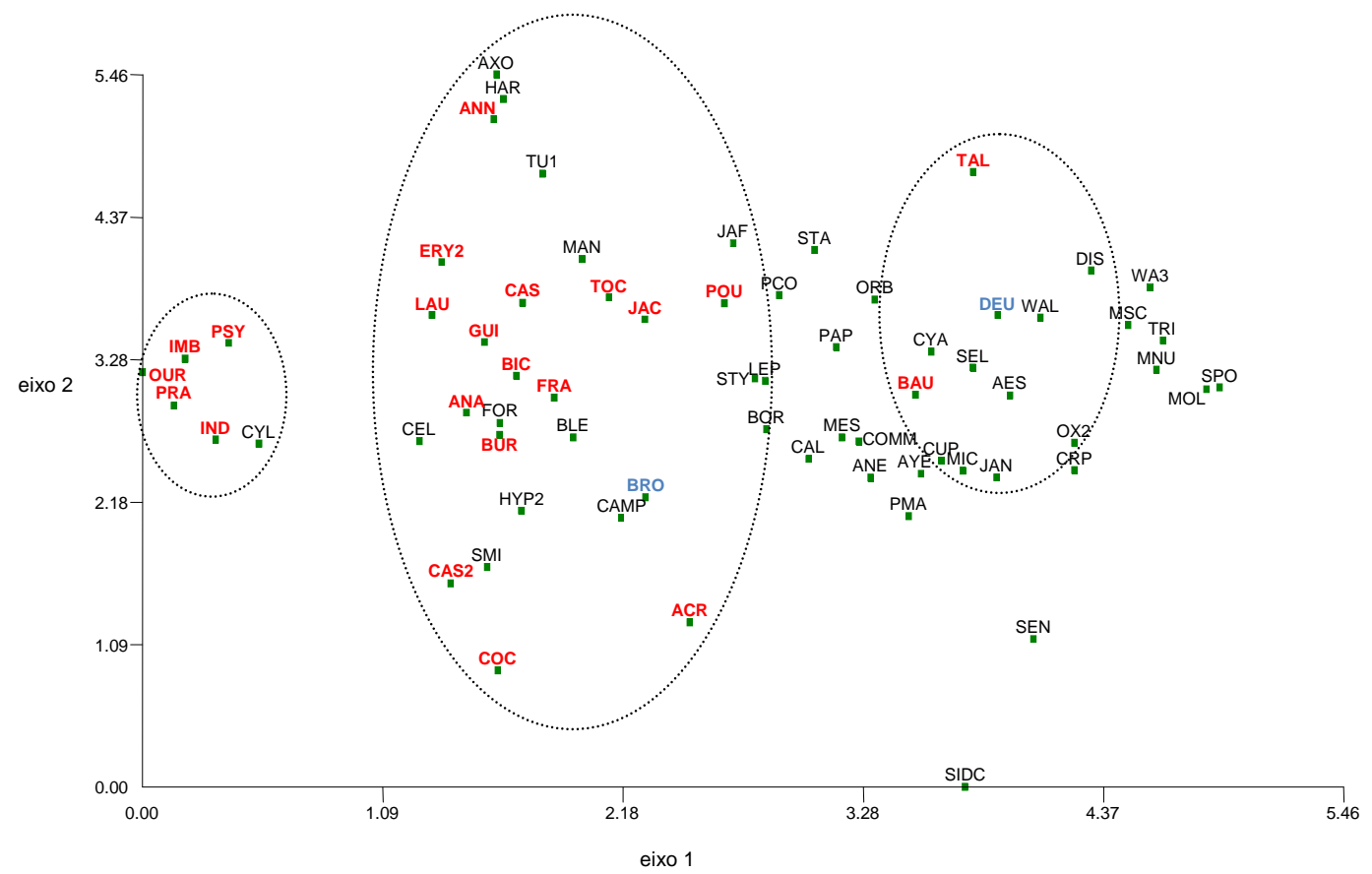

Figura 38 - Interpolação dos valores obtidos pela análise de correspondência modalidade DCA, utilizando o coeficiente de Hill, aplicada à matriz de dados padronizados com os valores de cobertura para as espécies com três ou mais ocorrências amostradas nas ilhas de solo dos afloramentos rochosos ferruginosos na Fazenda Monjolinho, em Corumbá, MS. Foram representadas em vermelho as espécies arbustivo-arbóreas e em azul escuro as espécies $\mathrm{BRO}=$ Bromelia balansae e DEU=Deuterocohnia meziana. As elipses representam dois grupos de espécies arbustivo-arbóreas associadas a Bromelia balansae e um grupo predominantemente herbáceo associado a Deuterocohnia meziana (ver texto para maiores detalhes). As abreviaturas das espécies constam no Anexo 2. 


\section{Relação entre tamanho insular e riqueza de espécies}

Analisando-se a totalidade das unidades insulares nos afloramentos rochosos ferruginosos observou-se que a relação entre a riqueza específica por unidade insular teve um aspecto curvilíneo conforme a interpolação dos valores observados na Figura 39. Quando estes dados foram transformados em escala logarítmica, observou-se um valor de $\mathrm{r}^{2}$ elevado $\left(\mathrm{r}^{2}=0,617\right)$ para a relação entre a riqueza específica por unidade insular, conforme a interpolação dos valores observados na Figura 39.

Analisando as áreas separadamente observou-se a mesma relação curvilínea entre o número de espécies e o tamanho insular com unidades menores apresentando menor número de espécies que ilhas maiores (Figura 40). 
A

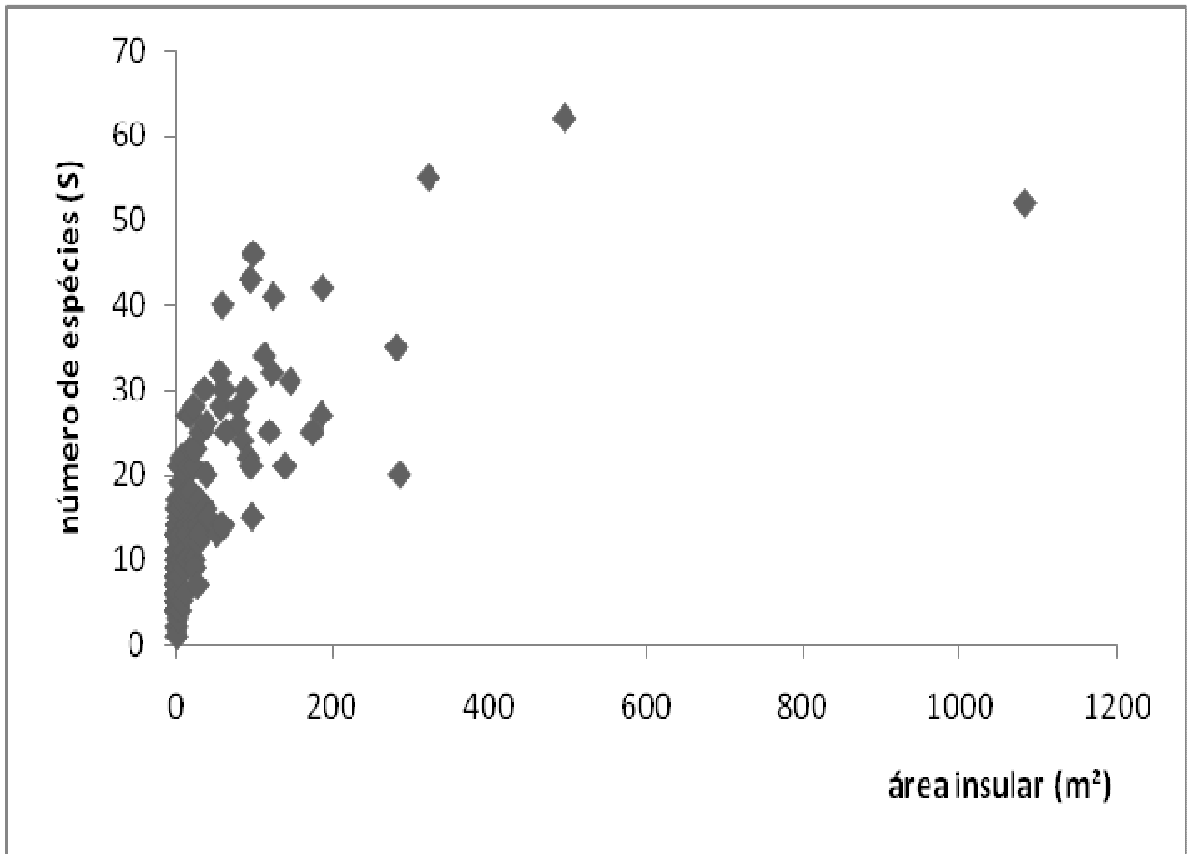

B

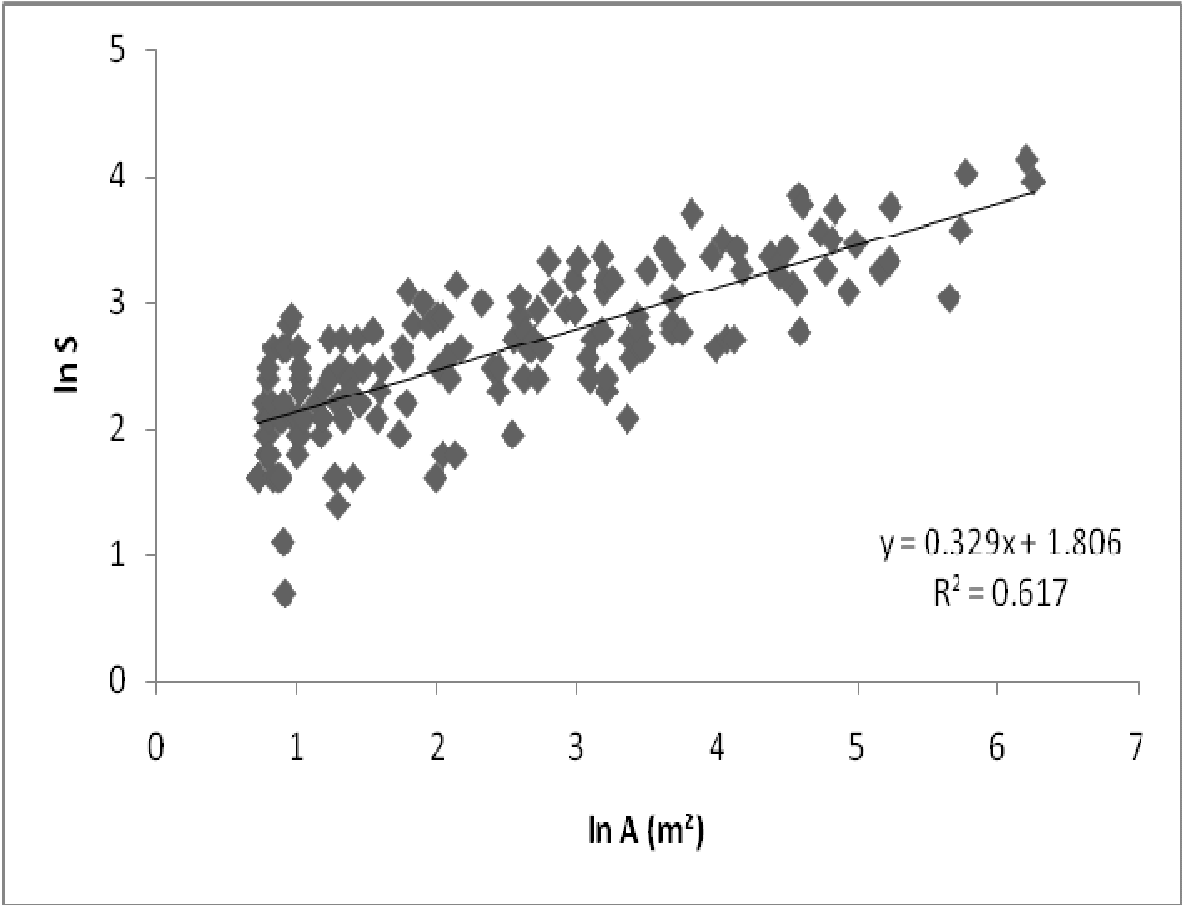

Figura 39 - Relação entre a riqueza de espécies (S) e a área das 164 ilhas de solo dos afloramentos rochosos ferruginosos em Corumbá, MS, A) com pontos interpolados em escalas lineares de número de espécies e áreas em metros quadrados, b) interpolação dos valores dos logaritmos naturais dos dados de riqueza específica e área (ln S - logaritmo neperiano da riqueza; ln A - logaritmo neperiano da área insular). A reta correspondente à função linear ajustada aparece representada entre os pontos. 
A

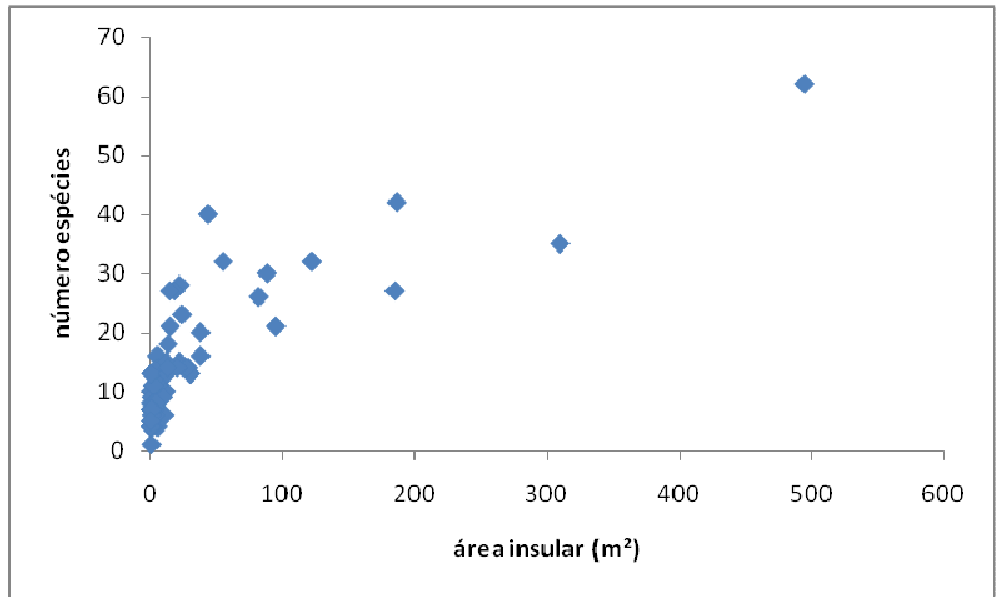

B

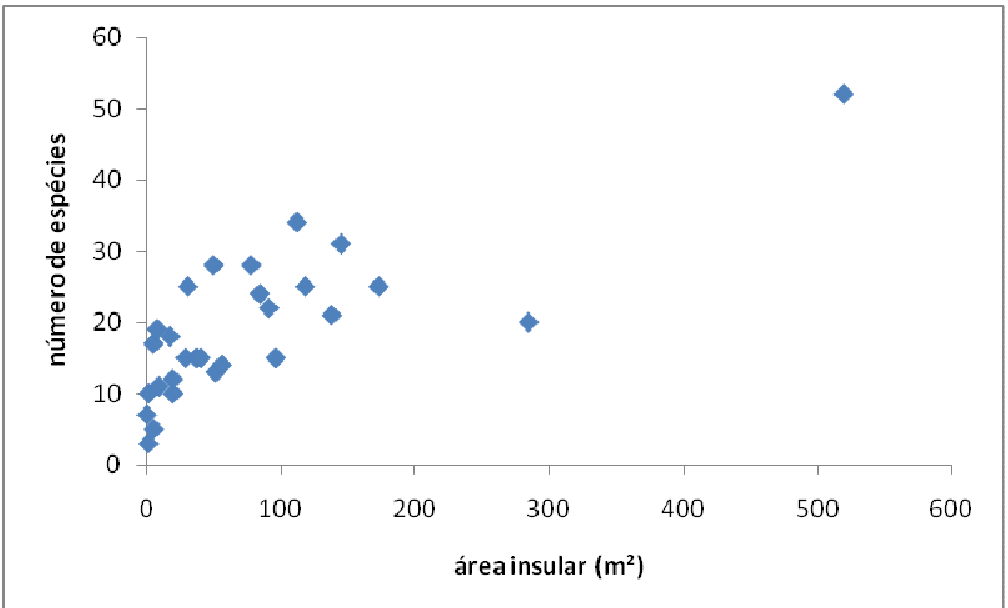

C

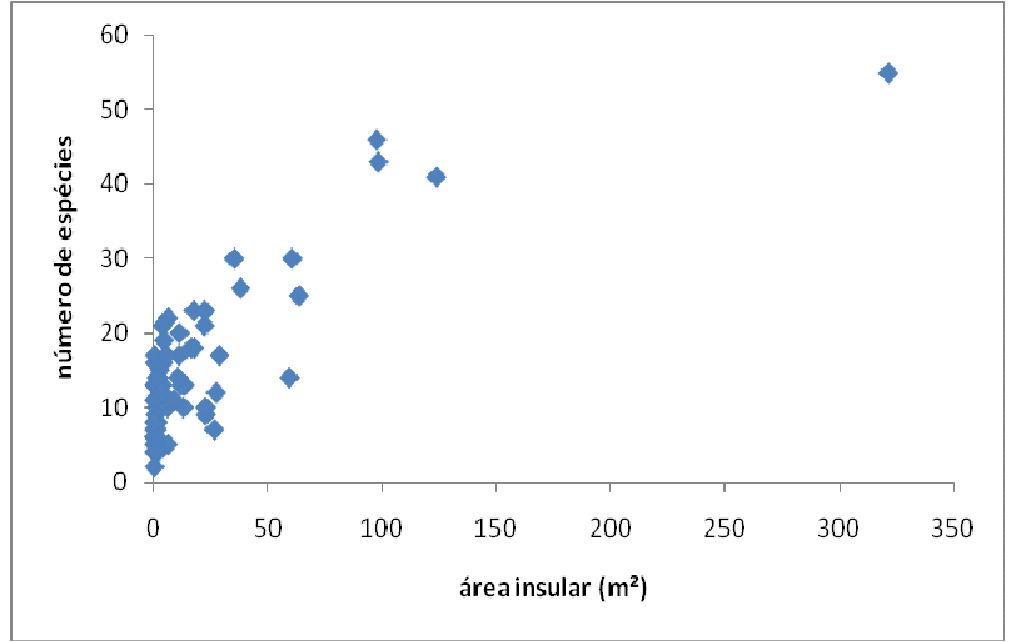

Figura 40 - Relação entre a riqueza de espécies (S) e a área das ilhas de solo dos três afloramentos rochosos ferruginosos em Corumbá, MS. A=Fazenda Banda Alta, B=Fazenda S.S.Carandá, C=Fazenda Monjolinho. 
Para cada localidade estudada foram propostos modelos de ajuste logarítmico, potência e exponencial para os parâmetros área (A) e riqueza (S) a partir da regressão não linear cujas equações correspondentes constam na Tabela 4 e a Figura 41 representa a função potência. $\mathrm{O}$ melhor ajuste às curvas dos dados pode ser conferido pelo maior coeficiente de determinação sendo a função potência para as Fazendas Banda Alta $\left(r^{2}=0,636\right)$ e S.S.Carandá $\left(r^{2}=0,626\right)$ e a função logaritmica para a Fazenda Monjolinho $\left(r^{2}=0,508\right)$ (Tabela 4). A análise das localidades em separado revelou que os dois primeiros sítios apresentaram modelos melhor definidos do que a Fazenda Monjolinho. 
A

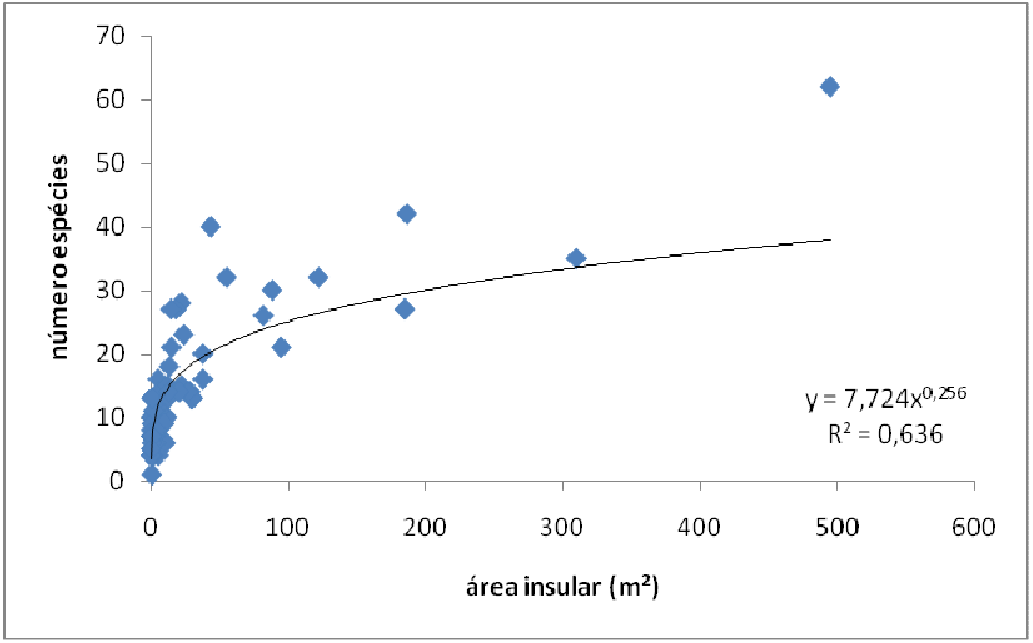

B

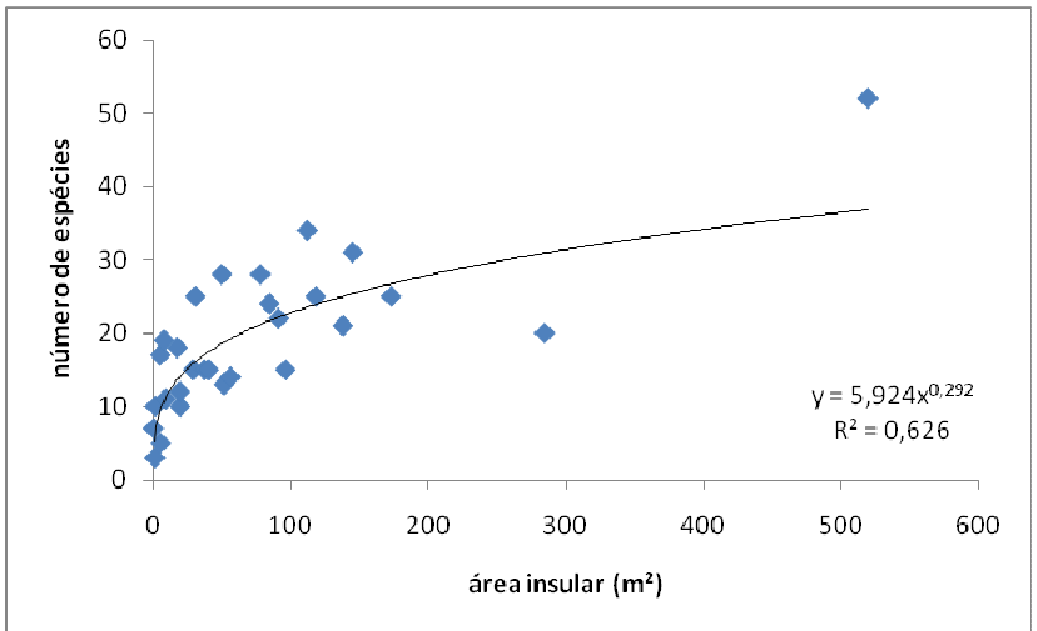

C

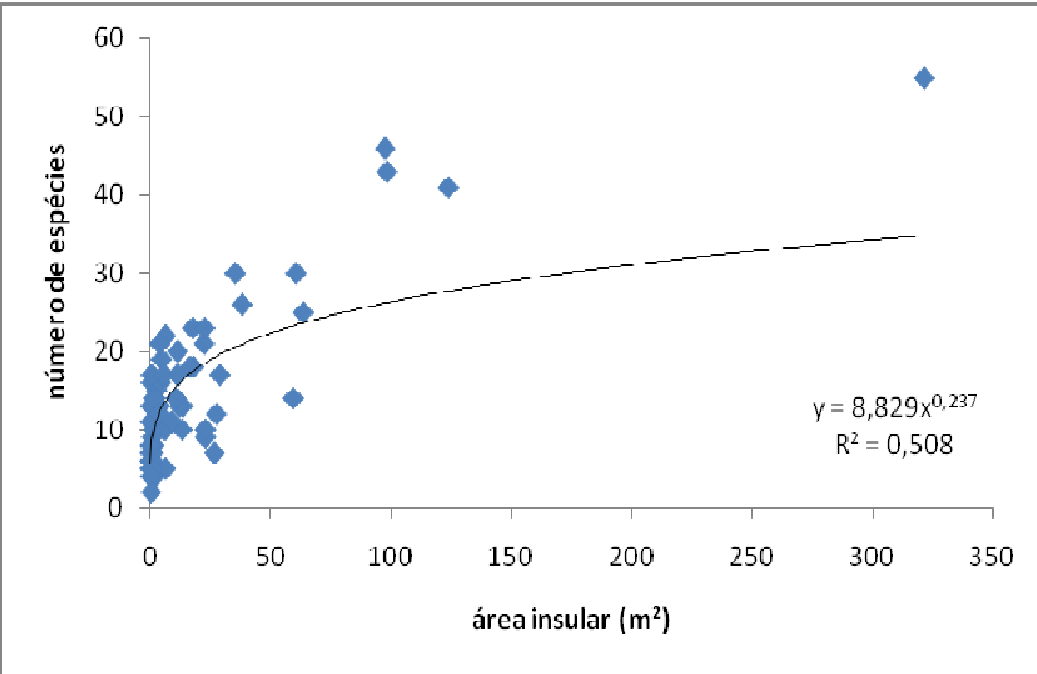

Figura 41 - Sobreposição da curva estimada pela função potência das variáveis área insular e riqueza de espécies $(S)$ nas ilhas de solo dos afloramentos rochosos ferruginosos em Corumbá, MS. A equação correspondente à curva é apresentada no gráfico, onde $\mathrm{R}^{2}$ é o coeficiente de determinação. $\mathrm{A}=$ Fazenda Banda Alta B=Fazenda S.S.Carandá e C=Fazenda Monjolinho 
Tabela 4 - Equações das relações entre área insular e riqueza de espécies, coeficientes de determinação para os três afloramentos ferruginosos de Corumbá, MS. A=Fazenda Banda Alta, B=Fazenda S.S.Carandá e C=Fazenda Monjolinho.

\begin{tabular}{|c|c|c|c|c|}
\hline Equação & Local & $\begin{array}{l}\text { Coeficiente de } \\
\text { determinação }\end{array}$ & $\begin{array}{l}\text { Coeficientes angular } \\
\text { (z) e linear (C) }\end{array}$ & Equação parametrizada \\
\hline \multirow[t]{6}{*}{$S=C+z(\ln A)$} & $\mathrm{A}$ & $\mathrm{R}^{2}=0.607$ & $C=8,587$ & $S=8,587+3,852 \cdot \ln A$ \\
\hline & & & $z=3,852$ & \\
\hline & B & $\mathrm{R}^{2}=0.594$ & $C=2,597$ & $S=2,597+4,678 \cdot \ln A$ \\
\hline & & & $z=4,678$ & \\
\hline & $\mathrm{C}$ & $\mathrm{R}^{2}=0.522$ & $C=9,637$ & $S=9,637+3,872 \cdot \ln A$ \\
\hline & & & $z=3,872$ & \\
\hline \multirow[t]{6}{*}{$S=C \cdot A^{z}$} & $\mathrm{~A}$ & $\mathrm{R}^{2}=0.636$ & $\mathrm{C}=7,724$ & $S=7,724 \cdot A^{0,256}$ \\
\hline & & & $z=0,256$ & \\
\hline & B & $\mathrm{R}^{2}=0.624$ & $C=5,924$ & $S=5,924 \cdot A^{0,292}$ \\
\hline & & & $z=0,292$ & \\
\hline & $\mathrm{C}$ & $\mathrm{R}^{2}=0.508$ & $C=8,829$ & $S=8,829 \cdot A^{0,237}$ \\
\hline & & & $z=0,237$ & \\
\hline \multirow[t]{6}{*}{$S=e^{C+z A}$} & $\mathrm{~A}$ & $\mathrm{R}^{2}=0.363$ & $C=9,461$ & $S=e^{9,461+0,005 A}$ \\
\hline & & & $z=0,005$ & \\
\hline & B & $\mathrm{R}^{2}=0.272$ & $C=14,10$ & $\mathrm{~S}=\mathrm{e}^{14,10+0,001 \mathrm{~A}}$ \\
\hline & & & $z=0,001$ & \\
\hline & $\mathrm{C}$ & $\mathrm{R}^{2}=0.334$ & $C=10,40$ & $S=\mathrm{e}^{10,40+0,008 \mathrm{~A}}$ \\
\hline & & & $z=0,008$ & \\
\hline
\end{tabular}

Para verificar o efeito insular sobre a riqueza de espécies procedeu-se a análises de correlação de Pearson entre os escores dos dois primeiros eixos resultantes da análise de correspondência e os valores das áreas das ilhas de solo, o número de espécies vasculares presentes, o número de monocotiledôneas e o índice de Shannon para cada ilha.

As correlação de Pearson foram significativas entre a área insular, em metros quadrados, e os escores do eixo 1 da DCA $(r=0,546, p<0,001)$, bem como 
para as unidade insulares da Fazenda Fazenda Banda Alta e o número de espécies $(\mathrm{r}=0,814, \mathrm{p}<0,001)$, assim como para o número de monocotiledôneas $(\mathrm{r}=0,719$, $\mathrm{p}<0,001)$, além do número de pteridófitas $(\mathrm{r}=0,531, \mathrm{p}<0,001)$ e, finalmente, para o índice de Shannon $(\mathrm{r}=0,614, \mathrm{p}<0,001)$.

As correlações de Pearson entre a área insular em metros quadrados e os escores do eixo 2 da DCA para as unidade insulares da Fazenda São Sebastião do Carandá foram significativas $(\mathrm{r}=0,536, \mathrm{p}<0,05)$, assim como entre o número de espécies $(r=0,745, p<0,001)$, bem como o número de monocotiledôneas $(r=0,633$, $\mathrm{p}<0,05)$ e, finalmente, o índice de Shannon $(\mathrm{r}=0,512, \mathrm{p}<0,05)$.

As correlações de Pearson entre a área insular em metros quadrados e os escores do eixo 1 da DCA para as unidade insulares da Fazenda Monjolinho foram significativas $(\mathrm{r}=0,541, \mathrm{p}<0,001)$, bem como para o número de espécies $(\mathrm{r}=0,797, \mathrm{p}<0,001)$, assim como para o número de monocotiledôneas $(\mathrm{r}=0,706$, $\mathrm{p}<0,001)$, além do número de pteridófitas $(\mathrm{r}=0,258, \mathrm{p}<0,05)$ e, finalmente, o índice de Shannon $(\mathrm{r}=0,518, \mathrm{p}<0,001)$. 
4. Relação entre a composição e cobertura das espécies nas ilhas de solo e a classe de tamanho

A Figura 42 mostra o efeito do tamanho insular na composição e cobertura de espécies vasculares presentes nas ilhas de solo onde foram registrados valores de cobertura e de espécies mais elevados para as maiores unidades insulares na Fazenda Banda Alta.

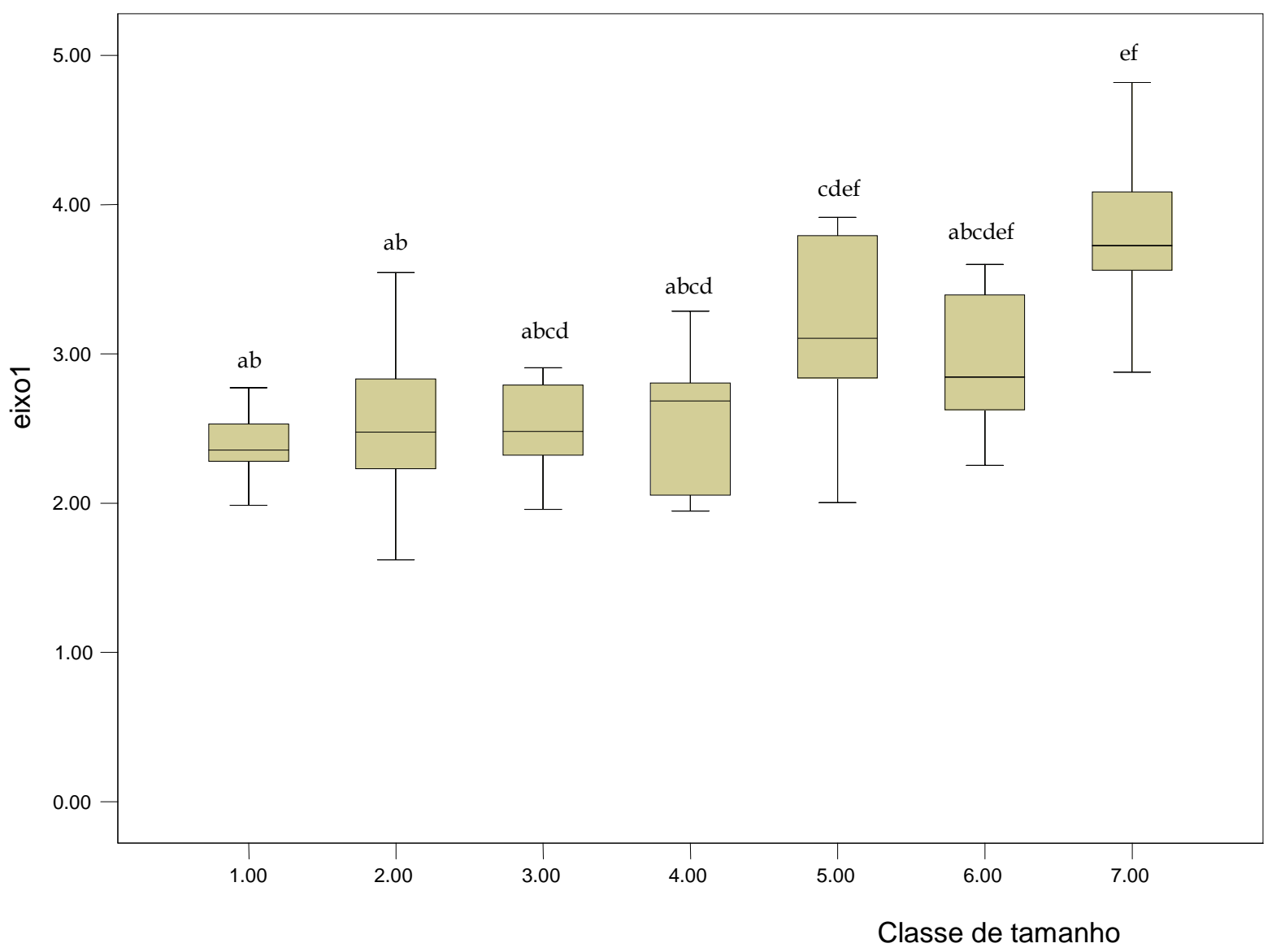

Figura 42 - Gráfico tipo "Box-plot" para os escores do eixo 1 da DCA para as unidades insulares e a classe de tamanho da ilha de solo nos afloramentos rochosos ferruginosos da Fazenda Banda Alta, Ladário, MS, com mediana e 
desvio-padrão. As letras minúsculas iguais indicam que não houve diferença significativa entre as classes de tamanho segundo o teste de Tukey $(p<0,05)$.

A análise de variância revelou que os escores do eixo 1 da DCA para as unidade insulares da Fazenda Banda Alta e as classes de tamanho foram significativamente diferentes $(n=69, \quad F=7,902, \quad p<0,001, d f=6) . \quad$ A análise de comparações múltiplas de Tuckey mostrou que as classes de tamanho 1, 2, 3 e 4 foram significativamente diferentes da classe 5 e $7(p<0,05)$ e foram definidos três grupos homogêneos: grupo 1 formado pelas classe de tamanho 1, 2, 3, 4 e 6; grupo 2 formado pelas classes 3, 4, 5 e 6, grupo 3 formado pelas classes 5, 6 e 7 .

A Figura 43 mostra uma tendência em aumento dos valores de cobertura e de número de espécies com o aumento do tamanho da ilha de solo para a Fazenda São Sebastião do Carandá. 


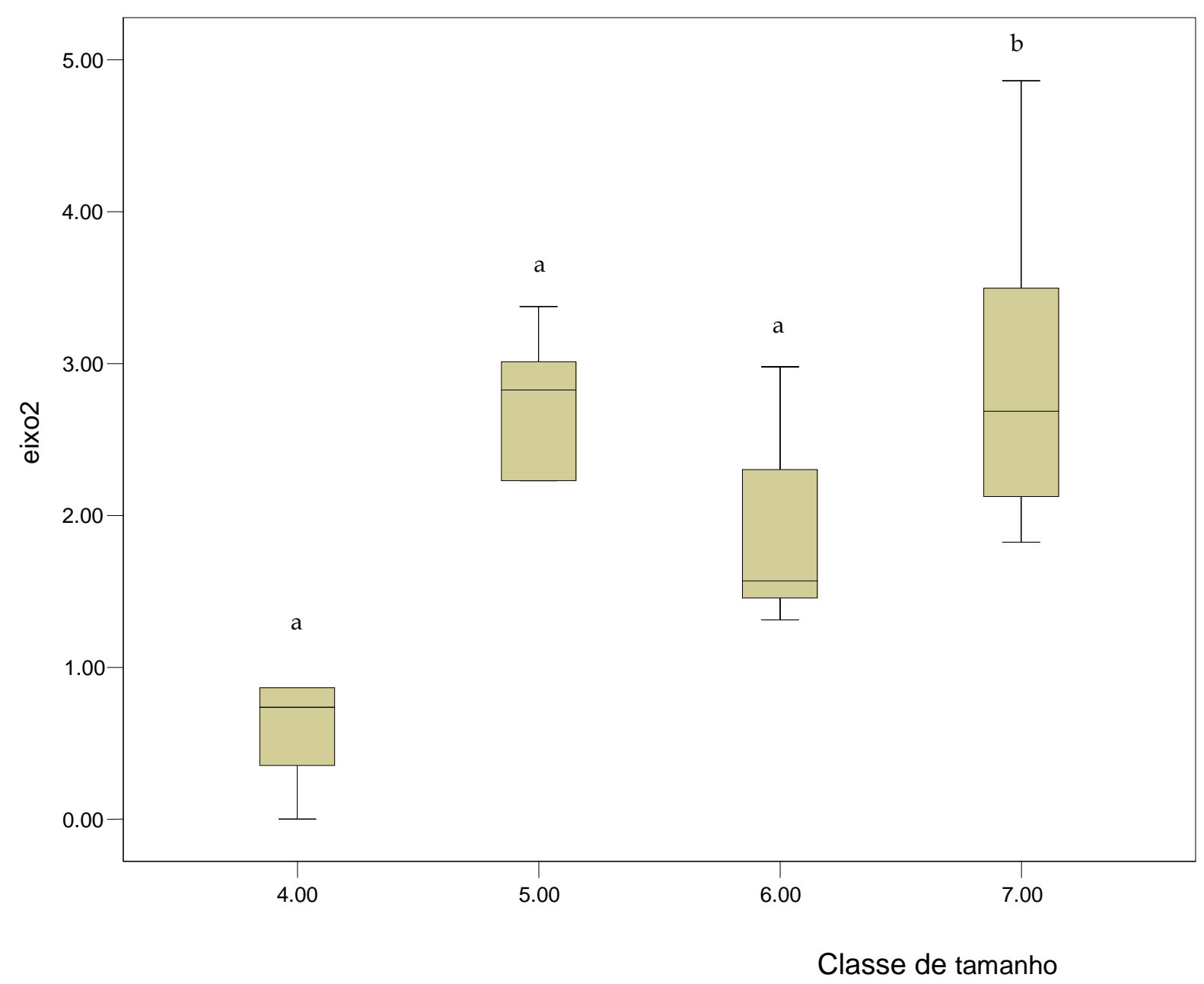

Figura 43 - Gráfico tipo "Box-plot" para os escores do eixo 2 da DCA para as unidades insulares e a classe de tamanho da ilha de solo nos afloramentos rochosos ferruginosos da Fazenda São Sebastião do Carandá, Ladário, MS, com mediana e desvio-padrão. As letras minúsculas iguais indicam que não houve diferença significativa entre as classes de tamanho segundo o teste de Tukey $(\mathrm{p}<0,05)$.

A análise de variância entre os escores do eixo 2 da DCA para as unidade insulares da Fazenda São Sebastião do Carandá e as classes de tamanho foi significativamente diferente $(\mathrm{n}=28, \mathrm{~F}=4,825, \mathrm{p}<0,05, \mathrm{df}=3)$. A análise de comparações múltiplas de Tuckey mostrou que as classes de tamanho 4, 5 e 6 
foram significativamente diferentes da classe $7(\mathrm{p}<0,05)$ e foram definidos dois grupos homogêneos: grupo 1 formado pelas classe de tamanho 4, 5 e 6; grupo 2 formado pelas classes 5, 6 e 7 .

A Figura 44 mostra um incremento na composição e cobertura das espécies presentes nas ilhas de solo na Fazenda Monjolinho em função do aumento do tamanho da ilha.

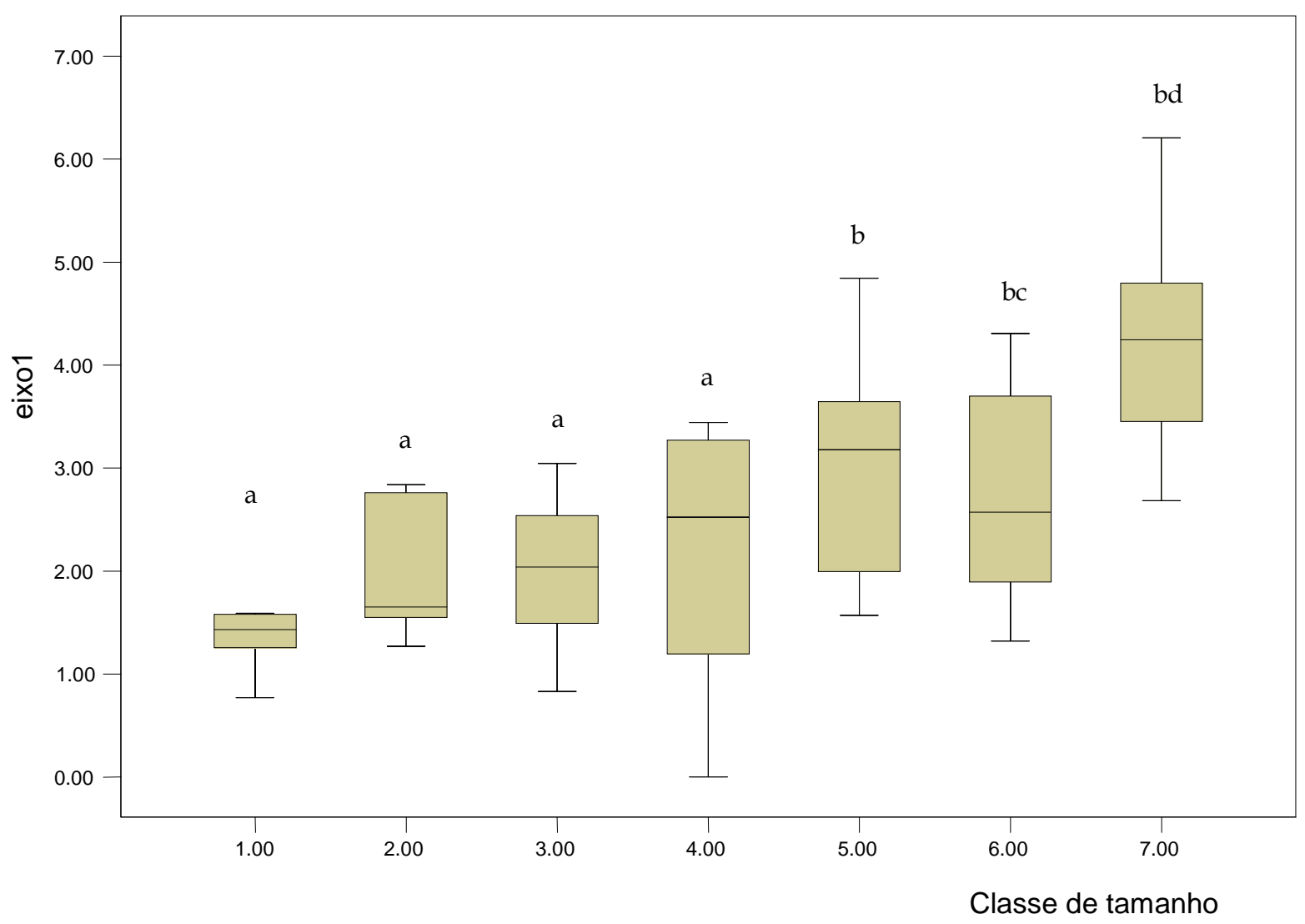

Figura 44 - Gráfico tipo "Box-plot" para os escores do eixo 1 da DCA para as unidades insulares e a classe de tamanho da ilha de solo nos afloramentos rochosos ferruginosos da Fazenda Monjolinho, Corumbá, MS, com mediana e desvio-padrão. As letras minúsculas iguais indicam que não houve diferença significativa entre as classes de tamanho segundo o teste de Tukey $(p<0,05)$. 
A análise de variância entre os escores do eixo 1 da DCA para as unidade insulares da Fazenda Monjolinho e as classes de tamanho foi significativamente diferente $(n=66, F=8,070, p<0,001, d f=6)$. A análise de comparações múltiplas de Tuckey mostrou que as classes de tamanho 1, 2, 3 e 4 foram significativamente diferentes das classes 5, 6 e $7(p<0,05)$ assim como entre a classe 6 e a 7 . Foram definidos três grupos homogêneos: grupo 1 formado pelas classe de tamanho 1, 2, 3 e 4; grupo 2 formado pelas classes 2, 3, 4, 5 e 6; grupo 3 formado pelas classes de tamanho 5 e 7. 


\section{Relação entre o grau da cobertura de espécies vasculares em ilhas de solo e as classes de tamanho}

Na Figura 45 observou-se como a cobertura das espécies variou em função das classes de tamanho das ilhas de solo. Como constatado para os resultados fitossociológicos Deuterocohnia meziana mostrou uma cobertura vegetal superior à de Bromelia balansae sendo registrada para todas as classes de tamanhos com uma acentuada redução de cobertura para a classe 7. Já o caraguatá (B.balansae) ocorre em classes de tamanho pequeno a grande com incremento nos valores de cobertura para as ilhas de solo maiores (Figura 45a).

Para as quatro espécies com os maiores valores de cobertura observou-se uma tendência em Selaginella sellowii, Sporobulus monandrus e Staelia sp. em apresentar maiores valores de cobertura nas ilhas pequenas e médias, decrescendo em ilhas maiores, enquanto os arbustos Mimosa xanthocentra tende a apresentar maiores valores em ilhas de solo com maiores valores de classe de tamanho (Figura 45b).

Para espécies arbustivo-arbóreas com os maiores valores de cobertura, observou-se que elas tendem a ocorrer em ilhas de tamanho maiores (Figura 45c), exceto Jatropha ribifolia um arbusto que ocorreu-se em ilhas pequenas e grandes. A Figura 45d mostra outras espécies arbóreo-arbustivas que estão ausentes em ilhas pequenas e somente são registradas em ilhas de classe de tamanho intermediário e grande, aumento os valores de cobertura com o aumento da área da ilhas. 
Considerando-se as pteridófitas e espécies vasculares tolerantes à dessecação (ou supostamente tolerantes) observaram-se diferentes estratégias (Figura 45e). As espécies tolerantes, Selaginella sellowii e S.convoluta ocorre em todas as classes de tamanho mas tendem a reduzir sua presença conforme o aumento do tamanho da ilha. Por outro lado, quatro espécies de pteridófitas ocorreram somente em unidades insulares maiores: Anemia tomentosa (classes 5, 6 e 7 ) e Selaginella marginata (classes 6 e 7), Doryopteris concolor e Cheilanthes tweediana (classe 7) sugerindo que mesmo espécies de plantas tolerantes à dessecação necessitem de um certo grau de sombreamento e neste caso conseguem apresentar valores de cobertura maiores já que o incremento em biomassa para este tipo de planta é bastante lento. O mesmo comportamento parece ocorrer para as duas gramíneas tolerantes, Microchloa indica e Tripogon spicatus, que ocorrem em todas as classes de tamanho mas tendem a apresentar maiores valores de cobertura em ilhas maiores. 
A

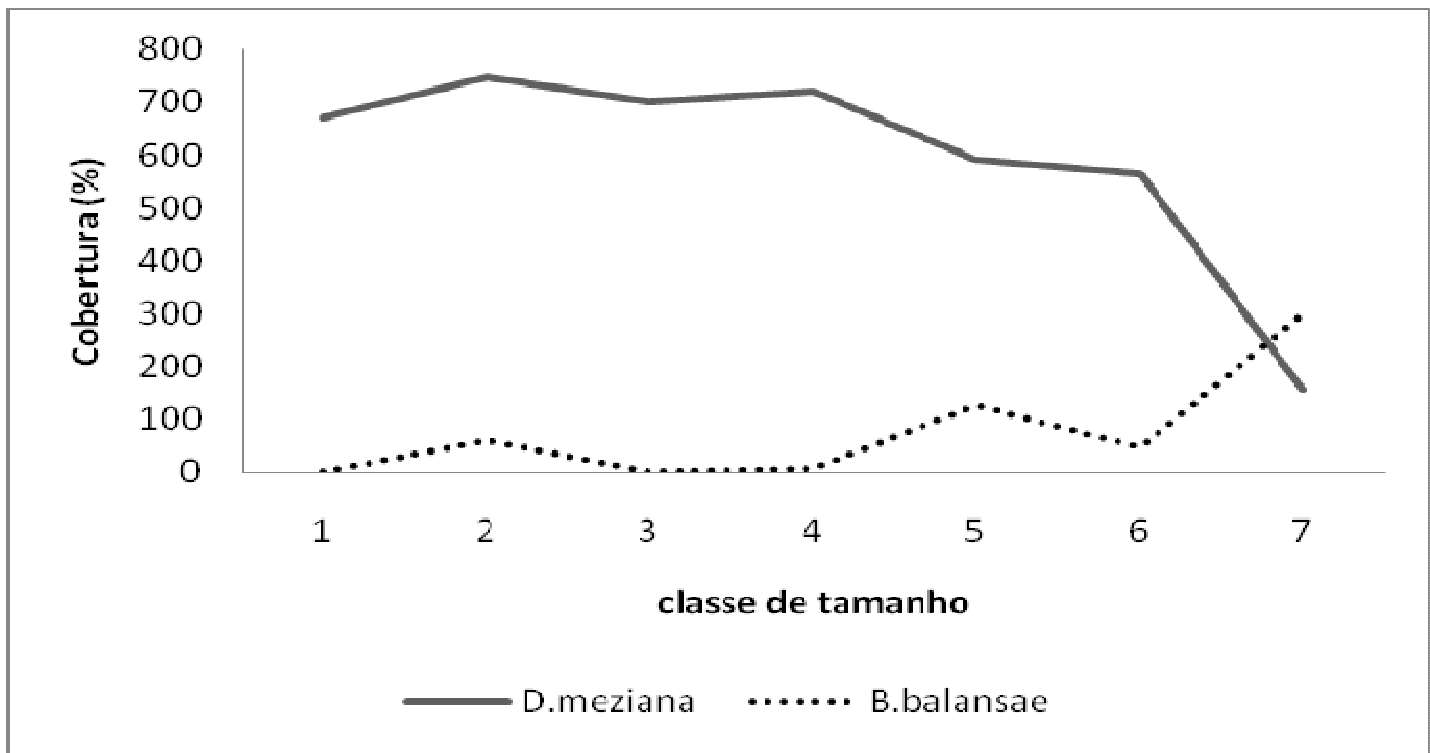

B

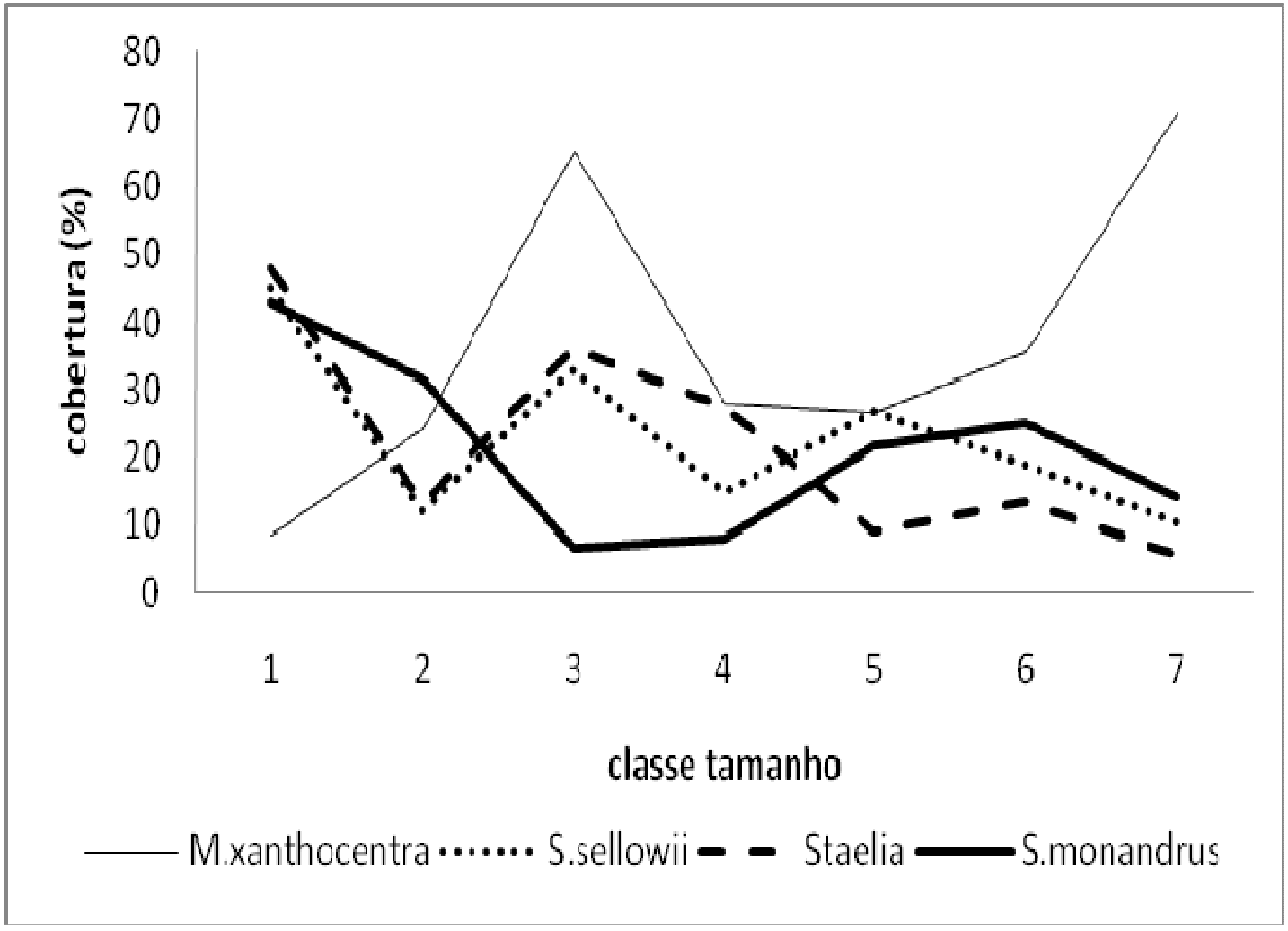

Figura 45 - Distribuição de valores de cobertura (\%) para as principais espécies vasculares de afloramentos rochosos ferruginosos em Corumbá, MS, por classe de tamanho. Para o nome completo das espécies consultar Anexo 1. 
C

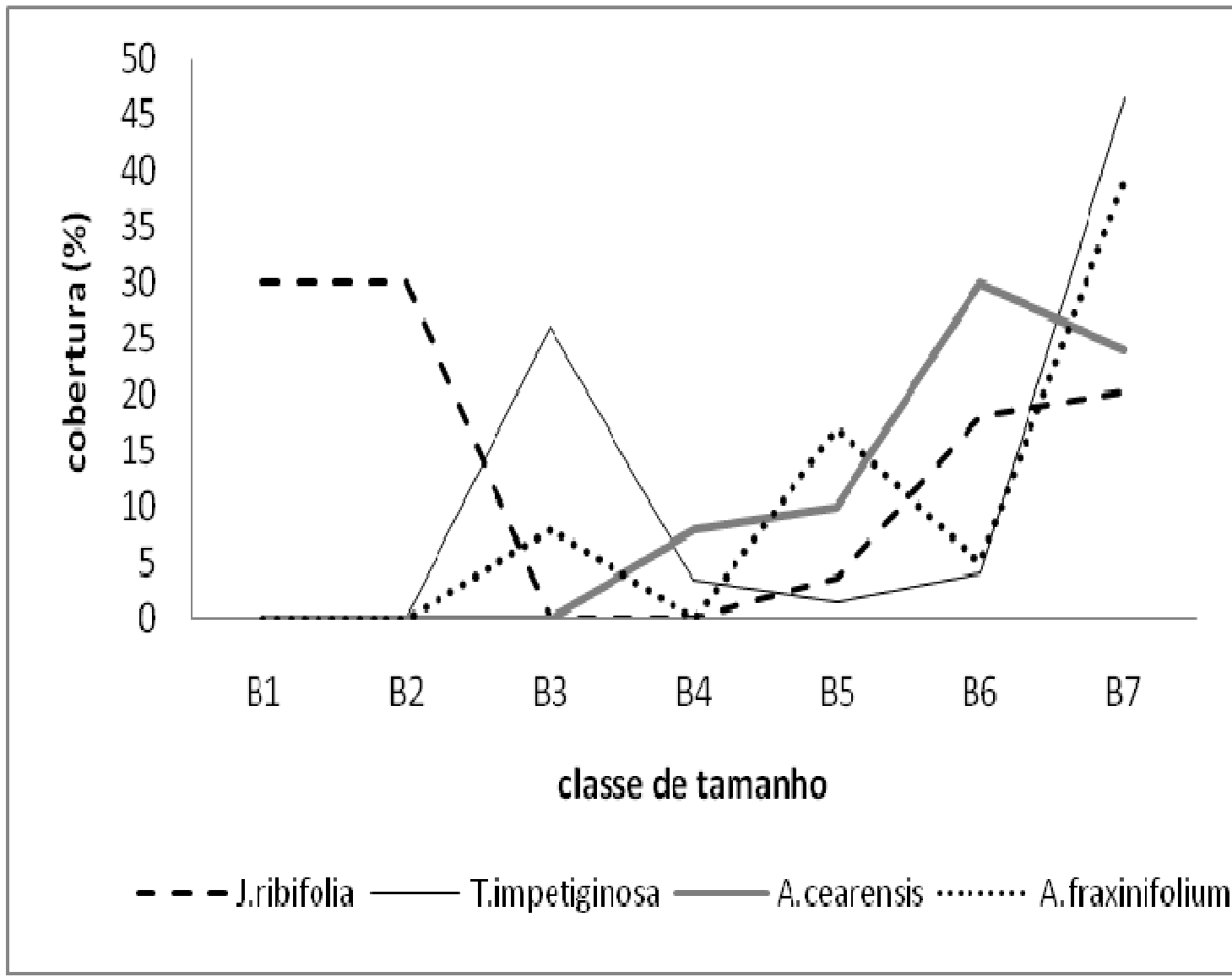

D

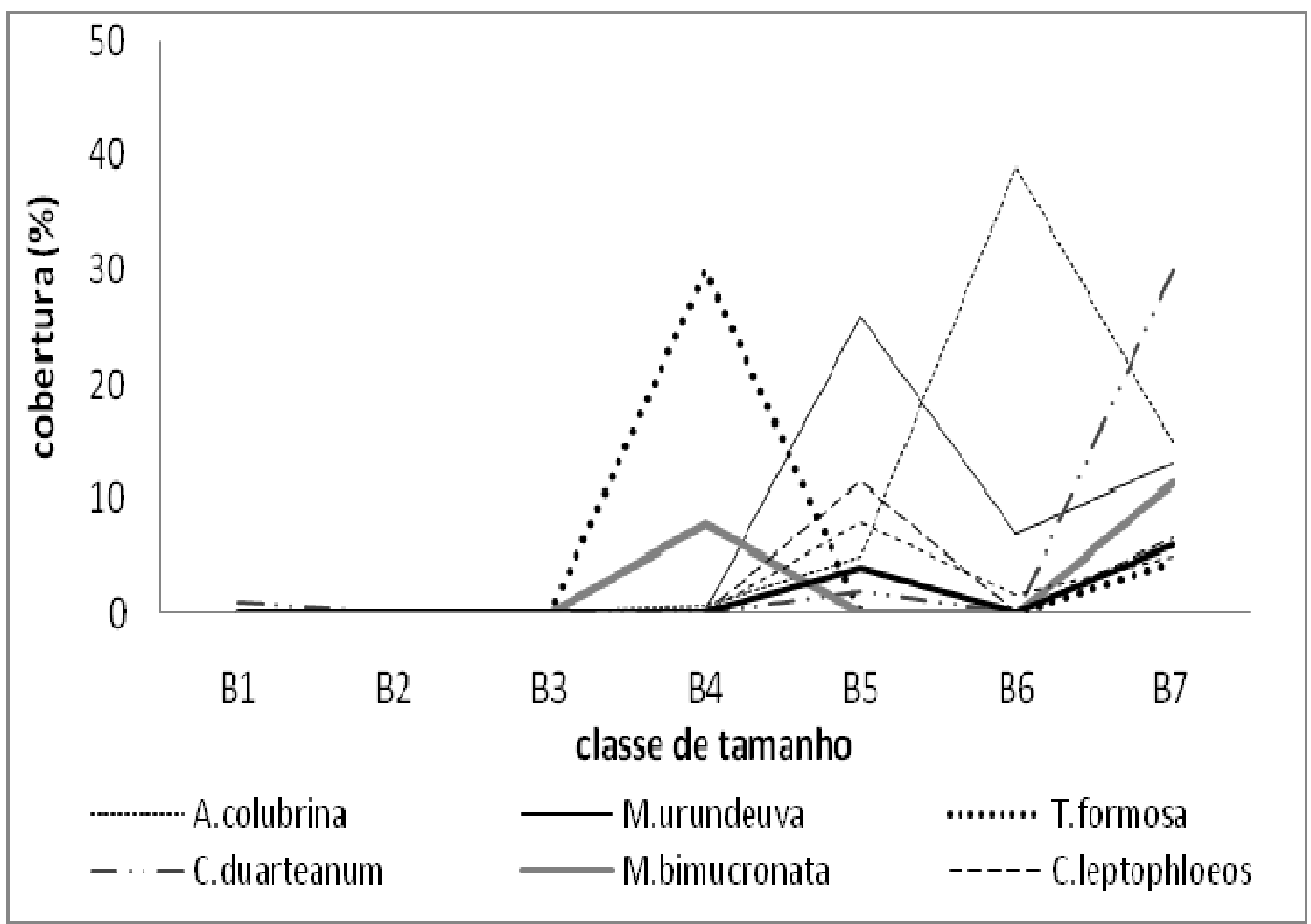

Figura 45 - continuação 


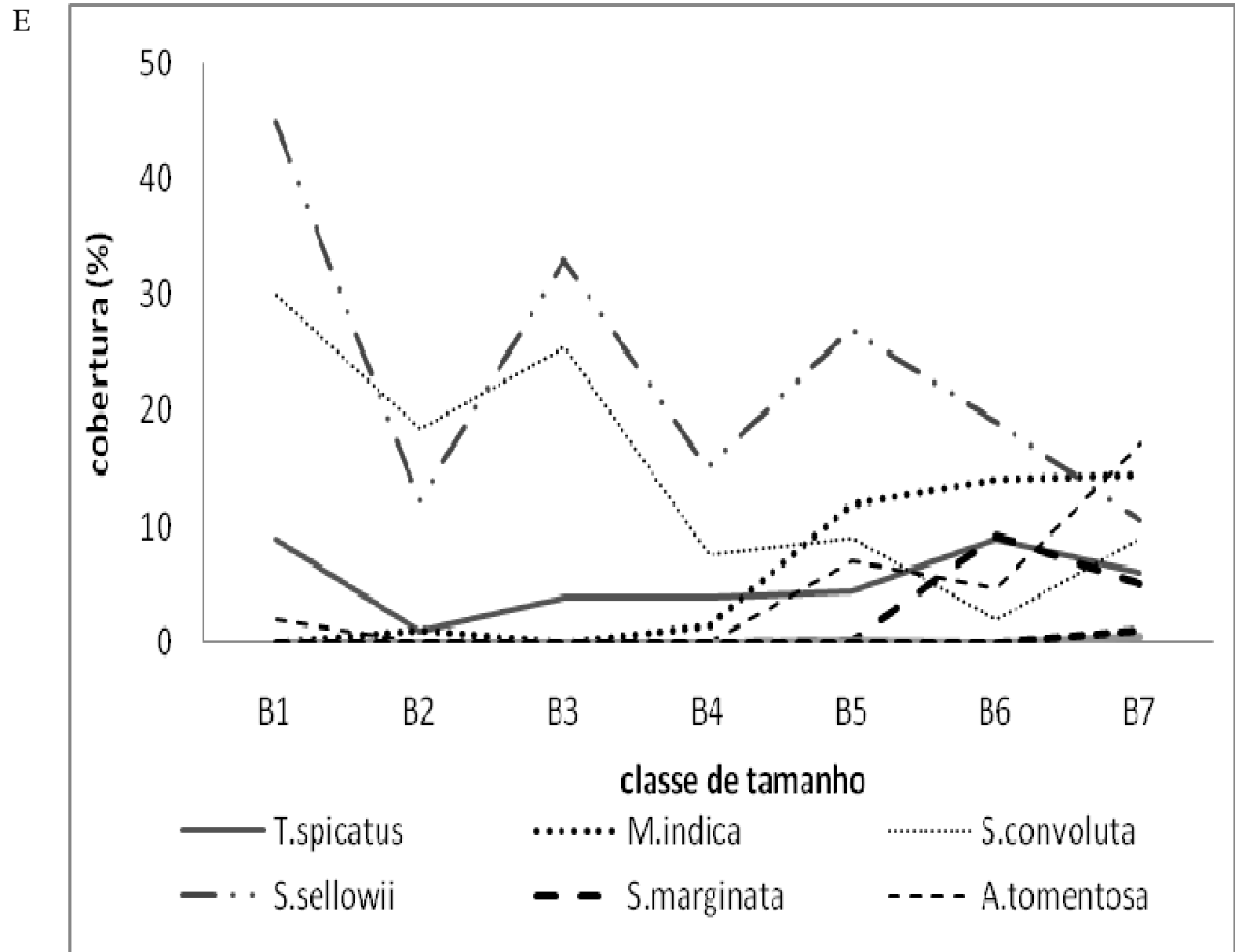

$\mathrm{F}$

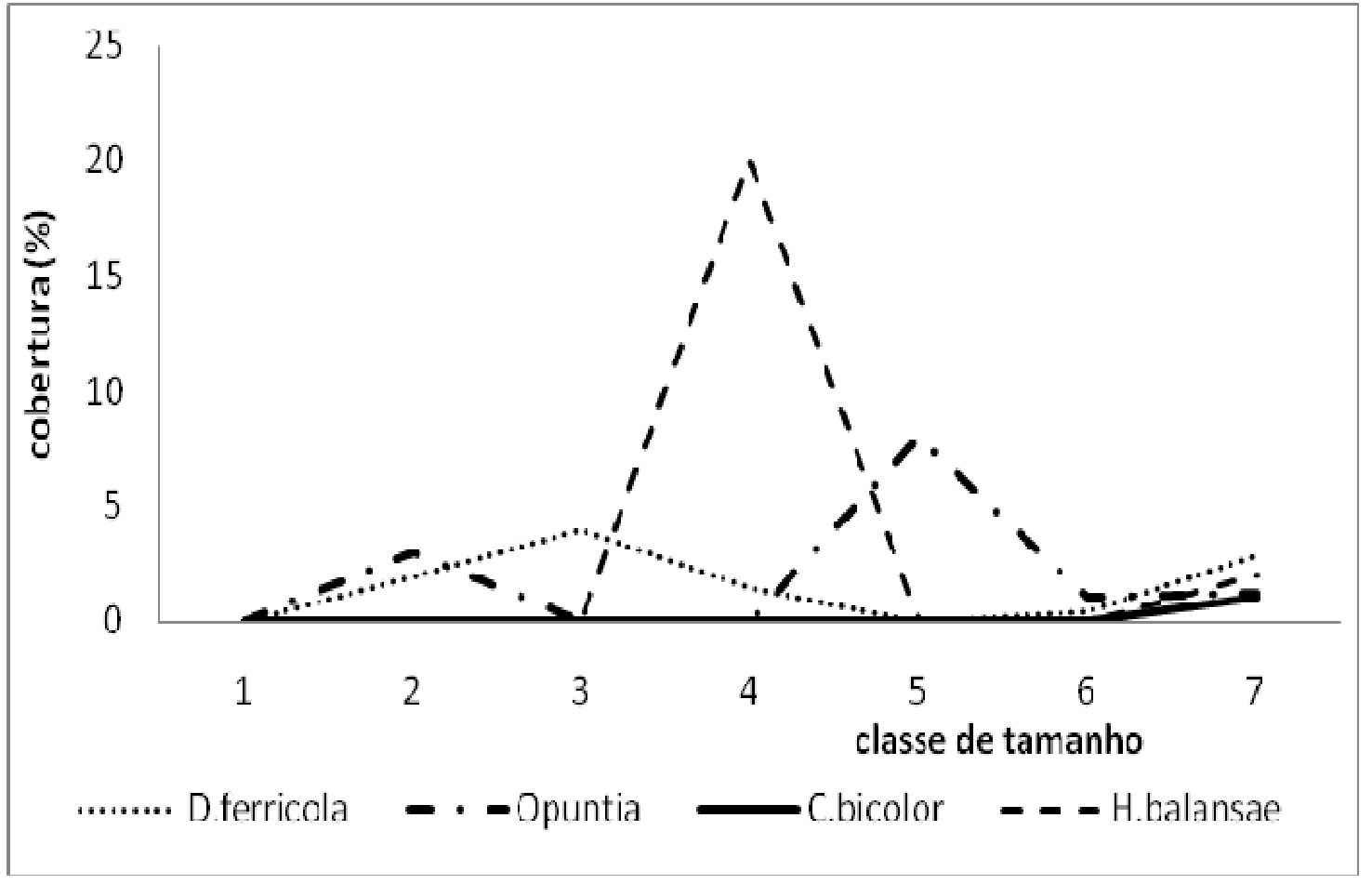

Figura 45 - continuação 
Quanto às cactáceas, foram representadas as espécies com os maiores valores de cobertura na Figura $45 \mathrm{f}$ observando-se que mesmo entre as suculentas diferentes estratégias foram observadas, desde aquelas plantas podem ocorrer isoladamente, sobre a superfície rochosa como Discocactus ferricola, que ocorreu nas classes de tamanho menores assim como nas ilhas maiores, e, neste caso, ficando restrita às bordas das ilhas e Cereus bicolor, que pode ocorrer isoladamente ou em ilhas de solo, assim como na mata decidual. As demais espécies parecem ocorrer em associação com outras espécies na ilha de solo, como Harisia balansae e C.bicolor foram registradas somente em classes de maior tamanho enquanto Opuntia sp. ocorreu em ilhas de tamanhos variados.

As demais espécies, especialmente as de menor porte, apresentaram comportamentos variados, com aumento ou decréscimo dos valores de cobertura em função do tamanho da ilha e não foram apresentados seus gráficos. 


\section{Discussão}

\section{- Florística dos afloramentos rochosos ferruginosos de Corumbá}

O levantamento da vegetação das cangas de Corumbá limitou-se a amostrar espécies circunscritas ao afloramento rochoso. Foram observadas plantas associadas a áreas de drenagem e escoamento lento da água das chuvas, como Cipura formosa e Zephyranthes cearensis. Outras espécies estiveram associadas estritamente ao substrato rochoso como Discocactus ferricola, Polycarpaea corymbosa e Gomphrena centrota e Portulaca sp1. A presença de depressões mais profundas e amplas da rocha associadas a baixa declividade do afloramento contribuiu para a formação de ilhas de solo maiores e o estabelecimento de espécies lenhosas como Astronium fraxinifollium, Commiphora leptophloeos, Jacaranda cuspidifolia e Myracrodruon urundeuva.

As comunidades vegetais das cangas de Corumbá foram compostas por espécies de ampla distribuição e oriundas de diferentes tipos de vegetação, como a caatinga e as matas decidual e semidecidual. Do total de espécies amostradas pelo presente trabalho, 30 delas foram registradas no levantamento fitossociológico da floresta decidual da cota 100 e 200 m da Morraria do Urucum por DamascenoJúnior (2005), salientando-se que este trabalho avaliou arbustos e árvores com circunferência a altura do peito maior ou igual a $15 \mathrm{~cm}$. Estes resultados destacam a importância da mata decidual como fonte de propágulos para os afloramentos rochosos ferruginosos de Corumbá e a capacidade destas espécies arbóreoarbustivas em se estabelecer sob condições bastante adversas. A constatação de 
um grande número de espécies compartilhadas pelos afloramentos rochosos e matas próximas foi um resultado semelhante ao obtido por Burke (2002) na Namíbia e por Hunter (2003) na Austrália.

Foi registrada uma espécie endêmica dos lajedos de Corumbá: Gomphrena centrota (Bortolotto et al. 1999, Pott et al. 2000) e uma espécie com distribuição restrita à região de Corumbá e de Mutum (Bolívia): Discocactus ferricola (Eggli 2002). Esta baixa frequência de espécies endêmicas também foi constatada para os afloramentos graníticos da Bolívia (Ibisch et al. 1995) e da Guiana Francesa (Sarthou \& Villiers 1998). Este resultado difere do que vem sendo registrado para os afloramentos rochosos do Sudeste brasileiro com grande número de espécies endêmicas ou restritas.

As famílias botânicas com maior número de espécies amostradas nas bancadas lateríticas foram Fabaceae e Poaceae, que possuem uma ampla distribuição em diferentes formações vegetais, de modo semelhante ao constatado para cangas da região de Carajás (Secco \& Mesquita 1983, Silva 1991) e do Quadrilátero Ferrífero (Viana \& Lombardi 2007), assim como para uma comunidade vegetal sobre afloramentos rochosos basálticos em São Paulo (Oliveira \& Godoi 2007), de afloramentos graníticos em Quixadá, Ceará (Araújo et al. 2008) e de afloramentos quartzítico-areníticos na Chapada Diamantina (Neves \& Conceição 2007).

A proporção elevada de espécies exclusivas de uma única localidade $(40 \%$ do total de espécies) determinou uma composição florística distinta em uma pequena distância o que, certamente, confere uma importância para a manutenção 
destas cangas. A baixa similaridade florística entre afloramentos rochosos próximos, de mesma litologia, também foi constatada para afloramentos graníticos-gnáissicos na Mata Atlântica (Meirelles et al. 1999), na Bolívia (Killeen \& Hinz 1992), na Guiana Francesa (Sarthou \& Villiers 1998), além de cangas em Minas Gerais (Vincent 2004, Jacobi et al. 2007).

As plantas vasculares que colonizam e se estabelecem nos afloramentos rochosos apresentam características fisiológicas ou morfológicas distintivas para ocupar estes ambientes. A habilidade de certos grupos de plantas em se adaptar a ambientes estressantes foi registrada para algumas espécies arbóreas em comunidades às margens da Floresta Atlântica verificando a relação entre a performance ecofisiológica, a frequência e a dominância da espécie na comunidade (Scarano et al. 2004, Scarano 2002).

É provável que resultados similares fossem constatados para a vegetação dos lajedos pois, apesar de não ter sido objeto desta pesquisa, verifica-se que diversas espécies frequentes não são observadas em outros tipos de ambientes, como os campos ferruginosos no topo da Morraria do Urucum (Iria Ishii, Geraldo Damasceno-Junior comunicação pessoal). Podem-se destacar características destas plantas que minimizam os efeitos negativos para o excesso de luminosidade e escassez de água, como o metabolismo CAM (p.ex. Deuterocohnia meziana), a poiquilohidria (p.ex. Selaginella sellowii), a proteção por gemas ou bulbos (p.ex. Cipura formosa, Zephyranthes cearensis) ou o ciclo de vida anual (p.ex. Mollugo verticillata). Além disso, a reprodução vegetativa, principalmente por brotamento, torna-se muito importante neste tipo de ambiente embora não constitua a única 
maneira de reprodução já que de 30 a 50\% das espécies se reproduzem obrigatoriamente por sementes (Hunter 2003).

Cerca de um terço das espécies foram amostradas nos dois tipos de comunidades vegetais presentes nas cangas (ilhas de solo e estrato herbáceo) enquanto $40 \%$ do total foram exclusivas das ilhas de solo. Este resultado sugere que a associação de espécies na forma de moitas pode decorrer de condições ambientais mais amenas nas ilhas de solo (Meirelles et al. 1999). Tal condição pode estar associada a uma dinâmica temporal caracterizada por um processo lento de ocupação do substrato em uma sucessão onde processos de facilitação tomam parte. O desenvolvimento da vegetação insular possibilitaria uma fonte de heterogeneidade possibilitando sua ocupação por diferentes grupos de espécies com diferentes configurações de nicho.

Entre as espécies amostradas destacou-se a pteridófita Selaginella sellowii registrada tanto em parcelas quanto em ilhas de solo de Corumbá. Esta planta distribui-se em outros afloramentos rochosos do Brasil, como no Rio Grande do Sul (Waldemar 1998), no Rio de Janeiro (Meirelles et al. 1999, Santos \& Sylvestre 2006), além da Chapada Diamantina (Conceição et al. 2007a) refletindo uma ampla distribuição, do México até a Bolívia (Hirai \& Prado 2000). Outra pteridófita com valores elevados de frequência relativa foi Anemia tomentosa registrada em afloramentos rochosos no Rio de Janeiro (Santos \& Sylvestre 2006) e considerada uma espécie tolerante a dessecação (Gaff 1987, Meirelles 1990). A maior parte dos componentes da flora dos lajedos foi composta por espécies de distribuição ampla, 
como por exemplo, Tripogon spicatus cuja ocorrência vai desde os EUA e México até a América do Sul.

Outra espécie bastante comum nos lajedos de Corumbá foi Discocactus ferricola tendo uma distribuição restrita à região de Corumbá e do Mutum, na Bolívia (Eggli 2002) encontrando-se na lista de espécies ameaçadas da CITES. A gramínea nativa do pantanal Mesosetum chaseae (Silva 2008) também foi um componente importante nas parcelas de $1 \times 1 \mathrm{~m}$.

A bromélia Deuterocohnia meziana caracterizou-se por formar agrupamentos homogêneos ("monocotyledonous mats"), ou associar-se a poucas espécies, de maneira bastante conspícua nas cangas de Corumbá. Esta espécie também foi registrada para afloramentos rochosos na Bolívia (Ibisch et al. 1995, Mostacedo et al. 2001).

Entre os componentes lenhosos podem-se citar as espécies com distribuição ampla ou oriundas de outras formações vegetais (p.ex.: Commiphora leptophloeos ocorre em afloramentos rochosos da Bolívia e na caatinga), assim como espécies de cerrados e matas secas (p.ex. Astronium fraxinifolium e Tocoyena formosa). A espécie arbustiva-arbórea Astronium fraxinifolium foi o componente mais importante para esta comunidade, foi citada com a mais frequente durante a revegetação natural em áreas de Neossolo Litólico, degradado pelo uso agrícola no norte de Minas Gerais (Caldeira Junior 2009) sugerindo-se um potencial de uso desta espécie para a recuperação de áreas degradadas. 


\section{- Estrutura da vegetaçaõ do estrato herbáceo nos afloramentos rochosos}

A baixa proporção de rocha nua, pedras ou solo exposto $(25 \%)$ revela que a cobertura vegetal do estrato herbáceo nestas cangas se dá de maneira relativamente contínua resultado distinto ao constatado em outros afloramentos rochosos onde a proporção de rocha é bem maior (p.ex. Caiafa \& Silva 2007, Neves \& Conceição 2007) e a ocorrência da vegetação fica restrita a depressões, fissuras, ou fendas (p.ex. Ribeiro et al. 2007). Tal fato pode ser decorrente da baixa declividade destes afloramentos em Corumbá o que reduz a ação deletéria de enxurradas e contribui para o acúmulo de uma fina camada de substrato na região próxima às drenagens. Devido as peculiares de cada sítio constatou-se que os valores de rocha nua, pedras soltas e solo exposto forma bem maiores na Fazenda Banda Alta do que nos outros locais. O atributo abiótico denominado pedras soltas não foi relevante para o estabelecimento de determinadas espécies mas simplesmente resultado da ação das enxurradas depositando-as morro abaixo.

As oito espécies ( $12 \%$ do total) com maiores valores de frequência relativa perfizeram cerca de $50 \%$ das unidades amostrais revelando que a composição variou em função das espécies menos abundantes. Duas espécies, Selaginella sellowii e Sporobulus monandrus, representaram cerca de 50\% dos valores de dominância relativa. Apenas sete espécies perfizeram pouco mais de $75 \%$ dos valores de dominância revelando que as condições adversas dos afloramentos determinam um baixo número de espécies a ocupar estes ambientes, bem como definem a estrutura destas comunidades. Os maiores valores de frequência, 
cobertura e valor de importância foram registrados para espécies que apresentam características fisiológicas de tolerância à seca (Selaginella sellowii e Tripogon spicatus) além da gramínea Sporobulus monandrus. Espécies resistentes à seca (Mesosetum chaseae) (Silva 2008) ou com ciclo de vida curto (como p.ex. Mimosa nuda, Mimosa xanthocentra, Staelia sp.; Cyperus uncinulatus) também se destacaram.

A composição e cobertura das espécies da Fazenda Banda Alta foi estratificada em dois habitats confirmando, estatisticamente, a diferença entre estes ambientes. As análises de ordenação também reforçaram a polarização entre estes habitats. O habitat "encharcado" encontra-se em uma posição topográfica que propicia o depósito de sedimentos e matéria orgânica oriundas das porções mais elevadas da Morraria e maior disponibilidade de água durante a estação chuvosa. Tais condições permitem o estabelecimento de espécies de ambientes sazonalmente encharcados e/ou que se estabelecem sobre um substrato mais profundo como: Cipura formosa, Zephyranthes cearensis, Fimbristilis sp., Ludwigia spp., entre outras. Por sua vez, a vegetação amostrada no habitat "seco" foi composta por espécies que se estabelecem diretamente sobre a rocha.

A avaliação da suficiência amostral baseada na curva acumulativa de espécies amostradas nas parcelas revelou uma estabilização aparente para a Fazenda S.S.Carandá. A coleta de dados quantitativos realizada durante a estação chuvosa reduziu as chances de que plantas efêmeras ou com partes aéreas não visíveis durante a estação seca não fossem amostradas. Entretanto, a elevada quantidade de ilhas de solo presentes nos afloramentos rochosos e, 
consequentemente, menor área de rocha exposta limitou a alocação das parcelas de $1 \times 1 \mathrm{~m}$.

\section{- Estrutura da vegetação em ilhas de solo nos afloramentos rochosos}

A proporção dos valores de freqüência relativa mostrou que a maioria das espécies ocorre em baixas freqüências (valores inferiores a 5\%). Isto sugere que a composição das ilhas de solo é dada por muitas espécies com valores de frequência baixos, de modo diverso ao observado para a vegetação herbácea amostrada em parcelas onde duas espécies representaram 50\% dos valores de dominância relativa. As espécies com os maiores valores de frequência e abundância corresponderiam aquelas que determinam a associação entre as espécies nas ilhas e a fisionomia da comunidade insular. Entre as espécies mais freqüentes foram observadas pteridófitas (Selaginella sellowii e Anemia tomentosa), bromeliáceas (Deuterocohnia meziana e Bromelia balansae), arbustos (Mimosa xanthocentra) e ervas (Calea elongata Staelia sp., Sporobolus monandrus). Já as espécies com maiores valores de dominância relativa foram as bromeliáceas citadas acima e componentes arbustivo-arbóreos, desde aqueles com distribuição ampla, como por exemplo Commiphora leptophloeos, assim como espécies de cerrados e matas secas (p.ex. Astronium fraxinifolium e Tocoyena formosa), além da pteridófita S.sellowii.

Entre as dez espécies mais relevantes nas comunidades de ilhas de solo e da vegetação herbácea, quatro delas (Selaginella sellowii, Sporobulus monandrus, Mimosa xanthocentra e Staelia sp.) foram importantes para ambas reforçando as diferenças na estrutura e composição destas duas comunidades. Os valores de valor de 
importância revelaram a estrutura principal das ilhas de solo: associação entre Deuterocohnia meziana, S.sellowii e outras espécies herbáceas ou a associação entre Bromelia balansae, elementos lenhosos arbustivos-arbóreos e ervas.

As ilhas de solo nas cangas de Corumbá apresentaram um aspecto bastante diverso do relatado para a maioria dos afloramentos rochosos tropicais e temperados pelo predomínio de fanerófitas e pela presença de ilhas arbustivas favorecida, pelo menos parcialmente, pela superfície quase plana destes afloramentos. Sarthou et al. 2009 já afirmaram que o componente lenhoso não tem sido considerado importante em outros afloramentos rochosos, exceto para a Guiana Francesa (Groger \& Huber 2007, Sarthou et al. 2003) e a Bolívia (Ibisch et al. 1995) e em diversos afloramentos graníticos as ilhas de vegetação ficam praticamente restrita às depressões da rocha (p.ex. Ribeiro et al. 2007).

As comunidades estabelecidas como estrato herbáceo contínuo e as comunidades de ilhas de solo nas cangas de Corumbá apresentaram composição florística e estrutura distintas. Embora quase a totalidade das plantas amostradas nas parcelas de $1 \times 1 \mathrm{~m}$ tenha sido registrada nas ilhas de solo o inverso não ocorre refletindo as diferentes estratégias de ocupação das plantas nos afloramentos, como já foi destacado para outros afloramentos rochosos (Burbanck \& Platt 1964).

Os resultados para a avaliação da suficiência amostral baseada na curva acumulativa de espécies amostradas nas ilhas de solo nos três locais estudados não mostraram uma estabilização aparente. Entretanto, deve-se levar em consideração que as ilhas de solo foram tratadas como unidades naturais, com tamanho e forma variáveis, não sendo possível aumentar seu tamanho 
indefinidamente ou, no caso da Fazenda S.S. Carandá, incluir unidades menores que não existiam. Outro ponto a ser destacado foi que o sorteio de 10 ilhas por classe de tamanho reduziu os efeitos de uma amostragem tendenciosa. Assim, estes resultados para a curva de avaliação da suficiência amostral refletem a característica da vegetação em ilhas de solo: dominância por poucas espécies sendo que a amostragem de espécies novas deve ser influenciada por diferentes fontes de propágulos, tanto no tempo quanto no espaço, e pela heterogeneidade ambiental no interior da ilha.

\section{- Características da comunidade}

\section{- Formas de vida}

A análise do espectro biológico para a totalidade das espécies amostradas nas bancadas lateríticas mostrou uma maior importância de hemicriptófitas, nanofanerófitas e microfanerófitas, denotando a relevância do componente arbustivo-arbóreo na composição das ilhas de solo estudadas. A predominância de hemicriptófitas nas Fazendas Banda Alta e Monjolinho está associada a fisionomia campestre enquanto o predomínio de fanerófitas na Fazenda São Sebastião do Carandá relaciona-se a fisionomia arbustivo-arbórea. As hemicriptófitas como forma de vida predominante foi registrada para o Parque Estadual da Serra do Brigadeiro, MG (Caiafa \& Silva 2005), a Pedra Grande em Atibaia, SP (Meirelles 1996) e o Parque Nacional do Itatiaia, RJ (Ribeiro et al. 2007).

As formas de vida predominantes para a vegetação do estrato herbáceo de Corumbá foram hemicriptófitas, nanofanerófitas, terófitas e caméfitas denotando 
uma fisionomia campestre para as cangas de Corumbá de modo semelhante ao observado para os quartzito-arenitos da Chapada Diamantina (Conceição \& Giulietti 2002, Conceição \& Pirani 2005) e para os campos de altitude da Serra do Brigadeiro (Caiafa \& Silva 2005). Quando as localidades foram analisadas separadamente constatou-se, diferentemente dos resultados para a totalidade de espécies, que caméfitas e hemicriptófitas predominaram na Fazenda Banda Alta face a maior proporção de rocha exposta, como observado para afloramentos rochosos quartzítico-areníticos da Chapada Diamantina, BA (Conceição et al. $2007 a, b)$.

As formas de vida predominantes nas ilhas de solo foram nanofanerófitas, hemicriptófitas e microfanerófitas sugerindo que os componentes perenes apresentam grande importância nas comunidades de cangas de Corumbá, em um resultado semelhante ao observado na Chapada Diamantina (Neves \& Conceição 2007) e no semi-árido da Bahia (França et al. 2005, 2006). O predomínio de fanerófitas (nanofanerófitas e microfanerófitas) observado para a Fazenda S.S.Carandá provavelmente deve-se a baixa proporção de rocha exposta neste local e a ocorrência de unidades insulares de maior tamanho. Nas outras duas áreas (Fazendas Banda Alta e Monjolinho) predominaram as formas de vida: hemicriptófitas e microfanerófitas devido ao elevado número de espécies arbustivo-arbóreas amostradas em ilhas de solo.

A presença de terófitas nas cangas de Corumbá pode estar relacionada aos ambientes sazonalmente encharcados e à dinâmica sazonal na composição da flora dos lajedos. Uma característica distintiva destas cangas foi a baixa ocorrência de 
geófitas. Afloramentos rochosos na África apresentam maior proporção de terófitas, de plantas com ciclo de vida curto e geófitas (Porembski et al. 1996). Uma característica ambiental que pode estar influenciando o predomínio das fanerófitas é a baixa declividade das cangas de Corumbá sem vertentes abruptas e íngremes, poças, concavidades mais profundas refletindo a posição destes afloramentos na parte inferior dos morros onde a ação de enxurradas destruindo e derrubando moitas de vegetação é menos intensa. A área de rocha exposta não é tão grande a ponto de impedir a colonização por plantas vasculares e a rebrota é uma característica vantajosa em ambientes extremos como os afloramentos (Hunter 2003).

\section{- Diagramas de perfil}

Os perfis esquemáticos representaram os dois modos de ocupação da vegetação dos afloramentos rochosos ferruginosos de Corumbá.

A vegetação do estrato herbáceo tende a ser mais esparso, de menor porte, com predomínio de ervas e representado por espécies associadas a uma maior proporção de rocha exposta, como Gomphrena centrota, Discocactus ferricola, Polycarpaea corymbosa e Portulaca sp.

A vegetação em ilhas de solo atinge maior porte, inclusive arbustivoarbóreo, podendo ser representada por uma espécie de bromélia, no caso, Deuterocohnia meziana, associada a poucas espécies principalmente herbáceas na periferia da ilha. No meio da ilha de solo, onde o substrato tende a ser mais 
profundo espécies arbustivas ou arbóreas podem se estabelecer, como por exemplo Astronium fraxinifolium.

\section{- Diversidade e equabilidade}

Os valores dos índices de diversidades de Shannon obtidos para as três áreas de estudo de Corumbá foram mais altos do que o obtido para as cangas do Parque Estadual da Serra do Rola Moça $\left(\mathrm{H}^{\prime}=2,45\right.$, Jacobi et al. 2008) e de afloramentos graníticos na Bahia $\left(\mathrm{H}^{\prime}=2,07\right.$, França et al. 2006) provavelmente influenciados pela amostragem do estrato herbáceo associado à comunidade insular além de uma maior área amostrada em Corumbá. Por outro lado, as cangas de Corumbá apresentaram valores de diversidade e equabilidade inferiores aos obtidos para os afloramentos de quartzito-arenitos da Chapada Diamantina do Platô Dois ( $\mathrm{H}^{\prime}=3,523$, Conceição \& Giulietti 2002).

A vegetação presente nas parcelas de $1 \times 1 \mathrm{~m}$ apresentaram valores dos índices de Shannon e equabilidade próximos aos observados para outros afloramentos rochosos do Brasil (França et al. 2006, Conceição \& Pirani 2005, Jacobi et al. 2008). A variedade de habitats ("seco" e "encharcado") na Fazenda Banda Alta deve ter influenciado os maiores valores obtidos do que as outras duas áreas.

Os valores dos índices de Shannon e equabilidade foram mais elevados para a vegetação amostrada em ilhas de solo do que para a vegetação amostrada nas parcelas de $1 \times 1 \mathrm{~m}$. Estes valores também foram mais elevados do que os encontrados para a comunidade em ilhas de vegetação da Chapada Diamantina (Conceição et al. 2007a). 
- Gradiente ambiental para a vegetação do estrato herbáceo dos afloramentos rochosos ferruginosos

Os arranjos apresentados nos gradientes revelados nas análises identificaram uma polarização entre espécies do estrato herbáceo associadas com sítios de maior proporção de rochas e espécies associadas com pontos de maior área de solo exposto. Isto é particularmente evidente na Fazenda Banda Alta onde há uma maior proporção de rocha exposta. Entre as espécies associadas ao substrato rochoso incluem-se Discocactus ferricola, Polycarpaea corymbosa, Portulaca sp1, Selaginella sellowii, Gomphrena centrota e Cyperus cornelli-ostenii. Essa ordenação revelaria a presença de substrato como um atributo que se constitui na principal fonte de variação dos padrões observados. De fato, as espécies que ocorrem diretamente sobre a superfície rochosa também podem se estabelecer em ilhas de solo onde, muitas vezes, ocupam suas bordas, mas o inverso não ocorre. A característica determinante nesse caso seria a contiguidade com a rocha, que predispõe a planta a um número maior de eventos de seca, com maior severidade, já que nesse ponto da estrutura insular não há solo suficiente para retenção prolongada da água da chuva.

Os arranjos apresentados nos gradientes revelados pelas análises de ordenação para a vegetação herbácea da Fazenda Banda Alta mostrou a polarização entre as parcelas com maior proporção de rocha exposta daquelas com maior profundidade do substrato. A análise de ordenação revelou um pequeno grupo formado pelas espécies Fimbristilis sp., Kyllinga odorata e Cipura formosa na 
porção do afloramento onde ocorre maior acúmulo de sedimentos trazidos pelas chuvas. Outro grupo foi constituído por espécies efêmeras que se estabeleceram durante o período de chuvas (exceto Selaginella convoluta, poiquiloídrica, e Zephyranthes cearensis, geófita) e também esteve relacionado a uma maior quantidade de substrato: Cyperus uncinullatus, Mimosa xanthocentra, Zephyranthes cearensis, Selaginella convoluta, Cleome guianensis, Ayenia tomentosa e Mimosa xanthocentra. As análises de ordenação mostraram que as parcelas com maior proporção de solo exposto esteve associadas a ocorrência das espécies Sporobulus monandrus e Mimosa nuda.

A Fazenda São Sebastião do Carandá possui baixa proporção de rocha exposta e, neste caso, as espécies Portulaca sp1 e Selaginella sellowii foram as principais espécies destas parcelas, como observado nas análises de ordenação. Embora uma fina camada de substrato recubra este afloramento por quase toda a sua extensão as análises de ordenação sugerem que um grupo de espécies esteja associado à parcelas com maior proporção de solo exposto: Fimbristilis sp., Mimosa xanthocentra, Evolvulus alopecuroides, Jacquemontia evolvuloides, Staelia sp., Aeschynomene histrix, Stachytarpheta matogrossensis, Zornia reticulata, Mimosa nuda, Microtea scabrida.

As análises de ordenação para a Fazenda Monjolinho revelaram que Polycarpaea corymbosa e Cyperus cornelli-ostenii estiveram associadas a parcelas com maior proporção de rocha nua, enquanto Discocactus ferricola, Portulaca sp1 e Selaginella sellowii estiveram relacionadas a parcelas com maiores proporções de solo exposto e pedras soltas. Estes resultados revelaram uma maior 
heterogeneidade da superfície rochosa do que as outras duas Fazendas. Este local também está mais sujeito a nevoeiros e, portanto, maior umidade atmosférica que pode ter determinado a presença quase contínua do estrato herbáceo onde, por exemplo, estolões de Mesosetum chaseae e ramos de Selaginella sellowii podem ser vistos ramificando-se sobre a superfície rochosa exposta mas se fixando nas pequenas depressões na rocha. Como já foi citado anteriormente, o atributo abiótico de pedras soltas não influenciou o estabelecimento e ocupação das plantas. As parcelas com maior proporção de solo exposto estiveram associadas a presença das espécies Selaginella sellowii, Portulaca sp1, Tripogon spicatus e Microchloa indica. Estas duas últimas espécies não ocorrem diretamente sobre a superfície rochosa e, quando registradas em ilhas de solo, geralmente ocupam porções periféricas da ilha com presença de substrato fino.

A preferência das espécies do estrato herbáceo a determinados atributos do afloramento rochoso ficou evidente quando se analisou a composição e cobertura das espécies nos habitats "seco" e "encharcado" da Fazenda Banda Alta. Os arranjos apresentados nos gradientes revelados nas análises de ordenação identificaram uma polarização entre as espécies que se estabelecem nestes dois habitats. Apesar das outras localidades estudadas apresentarem uma homogeneidade em relação ao substrato observou-se a preferência das espécies a determinados atributos dos afloramentos. Estes resultados sugerem que o estudo da vegetação sobre afloramentos rochosos deve levar em conta esta heterogeneidade ambiental, em uma escala mais fina, e evitar tratar este tipo de vegetação como uma comunidade homogênea. A abordagem do estudo da 
vegetação em afloramentos rochosos a partir dos diferentes habitats tem sido contemplada pelos estudos de Porembski e colaboradores mas poucos estudos no Brasil têm se preocupado com esta abordagem.

- Gradiente ambiental para a vegetação em ilhas de solo nos afloramentos rochosos ferruginosos

Os arranjos apresentados nos gradientes revelados pelas análises da vegetação em ilhas de solo identificaram uma polarização entre ilhas de solo com Deuterocohnia meziana e ilhas com Bromelia balansae. As ilhas de solo com D.meziana associaram-se a poucos elementos herbáceos enquanto as ilhas de solo com B.balansae tiveram uma combinação variada de espécies, principalmente arbustivoarbóreas.

Espécies herbáceas relacionadas a uma maior proporção de rocha exposta, tais como Discocactus ferricola, Selaginella sellowii, e Selaginella convoluta, associaramse em ilhas de solo com Deuterocohnia meziana na Fazenda Banda Alta. Por sua vez, as ilhas de solo da Fazenda Monjolinho contiveram diferentes componentes herbáceos além das já citadas espécies. Neste local também constatou-se que estas ilhas revelaram apresentaram duas espécies arbustivo-arbóreas, Bauhinia pentandra e Talisia esculenta. Ilhas de solo com maior proporção de rocha exposta e a presença das espécies e Gomphrena centrota, Polycarpaea corymbosa, Staelia sp. também foram observadas para esta Fazenda. Estes resultados revelaram que uma maior proporção de rocha exposta define a composição da ilha bem como a presença da bromeliácea D.meziana. 
As ilhas de solo com Bromelia balansae atingem os maiores tamanhos insulares, e frequentemente estão associadas a elementos arbustivos-arbóreos. A constituição de ilhas maiores proporciona uma maior heterogeneidade ambiental que, por sua vez, permitiu maior variedade na composição das ilhas de solo. A preferência por certos atributos dentro da unidade insular ficou evidente nas análises de ordenação da Fazenda S.S.Carandá enfatizando a segregação de ilhas com componentes herbáceos das ilhas de solo com compostos arbustivo-arbóreos. Nas Fazendas Banda Alta e Monjolinho as análises mostraram a associação das espécies arbustivas com a B.balansae.

As análises de ordenação revelaram algumas associações conspícuas entre espécies, como a associação entre B.balansae e Commiphora leptophloeos na Fazenda S.S.Carandá, enquanto esta bromélia associou-se a pteridófita Anemia tomentosa na Fazenda Banda Alta.

As ilhas de solo das Fazendas Banda Alta e Monjolinho apresentaram uma segregação entre as ilhas de B.balansae que se associam com diferentes espécies arbustivo-arbóreas e as ilhas de D.meziana, que formaram moitas homogêneas com componentes herbáceos e poucas espécies arbustivas, ressaltando um grupo extremo que apresenta espécies que se fixam diretamente à rocha na Fazenda Banda Alta. Já a Fazenda S.S.do Carandá mostrou uma segregação entre as ilhas com componentes herbáceos e ilhas com componentes arbustivo-arbóreos.

Destacaram-se três tipos distintos de ilhas de vegetação nas bancadas lateríticas: a) ilhas de Selaginella sellowii formando grupos homogêneos ou associada a poucas espécies herbáceas, b) ilhas de Deuterocohnia meziana, 
relativamente homogêneas, em locais mais íngremes e/ou de escoamento das águas de chuva e c) ilhas de Bromelia balansae, com composição variada frequentemente associadas a arbustos e árvores da mata seca, em canais de drenagem e depressões mais extensas. Estas três plantas foram as mais relevantes na definição da estrutura da vegetação que compõem as ilhas nas bancadas lateríticas com os maiores valores de importância, onde S.sellowii foi a espécie com maiores valores de freqüência em ilhas de solo enquanto D.meziana e B.balansae tiveram os maiores valores de dominância.

A distinção entre as duas comunidades (estrato herbáceo e ilhas de solo) foi nítida, bem como dentro das comunidades no que toca à composição e graus de cobertura das plantas, refletindo diferentes formas de ocupação do afloramento rochoso.

\section{- Características das ilhas de solo}

Considerando-se que as cangas de Corumbá registraram 181 espécies em 164 ilhas amostradas em uma área de $6206 \mathrm{~m}^{2}$ isto representa um valor de 0,03 espécies $/ \mathrm{m}^{2}$. Este foi um valor próximo ao observado para afloramentos rochosos do Rio de Janeiro, com 85 espécies em 347 ilhas totalizando $1264 \mathrm{~m}^{2}$ de área amostrada, equivalendo a 0,07espécie $/ \mathrm{m}^{2}$. Comparando-se estes valores com outros estudos de ilhas de solo no Brasil temos valores um pouco maiores para as ilhas de solo da Pedra Grande, em Atibaia, SP, sendo registradas 101 espécies vasculares em 88 ilhas de solo e área amostrada de $609 \mathrm{~m}^{2}$, representando 0,16 espécie $/ \mathrm{m}^{2}$. Nas unidades insulares da Chapada Diamantina foram registradas 
135 espécies vasculares em 214 ilhas somando $568 \mathrm{~m}^{2}$, equivalente a 0,24 espécie/m². Em Itatiaia, no RJ, foram amostradas 114 espécies em 197 ilhas de solo totalizando $336,6 \mathrm{~m}^{2}$, equivalendo a 0,34 espécie $/ \mathrm{m}^{2}$. O Morro do Pai Inácio teve o maior valor para o número de espécies por metro quadrado $\left(0,84 \mathrm{sp} / \mathrm{m}^{2}\right)$, onde foram amostradas 63 espécies em 78 ilhas de solo totalizando $74,8 \mathrm{~m}^{2}$.

A riqueza de pteridófitas correlacionou-se positivamente com a área das ilhas de solo da Fazenda Banda Alta, pela associação de Anemia tomentosa e de Cheilanthes tweediana com Bromelia balansae em ilhas de maior tamanho, bem como a associação entre Selaginella spp e outras espécies de angiospermas em ilhas menores. A associação entre Bromelia balansae, Anemia tomentosa e Cheilanthes tweediana foi bastante conspícua onde as duas espécies de pteridófitas apresentaram enrolamento e desidratação das folhas que indicam a presença de tolerância a dessecação. Entretanto, estas plantas não ocorrem isoladamente, como constatado para Selaginella sellowii, o que pode estar relacionado à umbrofilia como já foi registrado para outras criptógamas vasculares tolerantes à dessecação destes gêneros (Meirelles 1996). Espécies tolerantes e não tolerantes à dessecação convivem em ilhas de monocotiledôneas em afloramentos rochosos no Brasil e, com o aumento da área insular, as espécies tolerantes à dessecação ocupam a periferia da mesma (Porembski \& Barthlott 2000).

A relação positiva entre área insular e o número de espécies de monocotiledôneas nas ilhas de solo em Corumbá reforça a importância deste grupo de plantas em afloramentos rochosos neotropicais. Esta característica denomina, inclusive, um tipo de habitat, as moitas de monocotiledôneas 
("monocotyledonous mats") (Porembski et al. 1997, Porembski 2007). Este padrão surge pela capacidade destas plantas de sobreviver em ambientes inóspitos e de se reproduzir vegetativamente (Ibisch et al. 1995).

- Relação entre tamanho insular e riqueza de espécies nas ilhas de solo

O número de espécies presentes e o índice de Shannon das unidades insulares correlacionaram-se positivamente com a área insular nos três locais estudados sugerindo que o aumento do tamanho da ilha condiciona o aumento do número de espécies coexistentes assim como a diversidade da mesma.

A relação espécie-área em ilhas de solo de afloramentos rochosos pode ser explorada uma vez que estas unidades são consideradas unidades naturais com tamanhos e formas variados (na maioria dos casos, elipses) e, deste modo, consideradas sistemas terrestres equivalentes às ilhas oceânicas.

A relação espécie-área observada para as ilhas de solo dos três sítios analisados e para a totalidade das unidades insulares corrobora os resultados obtidos em várias comunidades insulares (Lomolino 2000, Connor \& McCoy 1979). Todos os modelos propostos aqui (potência, exponencial e logarítmico) contribuíram significativamente para a redução da variância da estimativa sendo, portanto, a escolha do melhor modelo efetuada pelo coeficiente de determinação. Assim, a função potência foi considerada a melhor aproximação aos dados empíricos na relação entre área insular e riqueza para as Fazendas Banda Alta e S.S.Carandá, enquanto a função logarítmica foi o melhor ajuste para os dados da Fazenda Monjolinho. A função potência frequentemente é citada na literatura 
como o melhor modelo para expressar a relação entre riqueza e área (Kallimanis et al. 2008, Scheiner 2003, Gilbert 1980, Connor \& McCoy 1979). Esta função consistiu no melhor ajuste para os dados empíricos para a riqueza específica em unidades insulares rupícolas de afloramentos graníticos em Atibaia, SP, em função da área (Meirelles 1996). Para outras comunidades insulares em afloramentos rochosos o modelo exponencial foi relatado como o melhor ajuste para os dados empíricos da vegetação nos EUA (Houle 1990) e na Venezuela (Michelangeli 2000). Os valores de z para a função potência nas cangas de Corumbá foram considerados dentro do intervalo de 0,20 e 0,35 predito por MacArthur \& Wilson (1967) e do intervalo da distribuição canônica de Preston, entre 0,17 e 0,35 (Connor \& McCoy 1979).

- Relação entre classe de tamanho insular e cobertura das espécies nas ilhas de solo

Os dados empíricos mostraram que os valores de cobertura das espécies dos afloramentos rochosos ferruginosos aumentaram em função do tamanho da ilha sendo constatadas diferenças significativas entre as classes de tamanho menores e as maiores. Esta análise utilizou a classe de tamanho da unidade insular, ao invés da área em metros quadrados, e os resultados mostraram que nas três cangas estudadas a composição e cobertura das espécies foram determinadas pelo tamanho da ilha.

O tamanho insular esteve correlacionado positivamente com a riqueza específica e o índice de Shannon confirmado os resultados obtidos anteriormente. Os dados empíricos para a relação entre o índice de Shannon em cada unidade 
insular e a área em metros quadrados mostrou um maior coeficiente de determinação para a Fazenda Banda Alta seguida pelas Fazendas S.S.Carandá e Monjolinho. Neste caso, algumas unidades insulares de menor tamanho apresentaram valores de Shannon mais elevados do que ilhas maiores em função da distribuição de abundância das espécies na unidade considerada.

As funções potência e logarítmica são citadas como bons descritores para a relação espécie-área de comunidades insulares, particularmente para as ilhas de solo tomadas como unidades naturais discretas, mas se utilizadas como modelos preditivos deve-se considerar que outros fatores biológicos e ambientais podem atuar. Scheiner (2003) ressaltou que unidades insulares discretas (como lagos, topos de montanhas, florestas isoladas) apresentam curvas de número de espécies versus área que não necessitam apresentar um patamar de estabilização, como o esperado, pois dados empíricos mostram ser possível que uma ilha grande contenha menos espécies do que uma ilha pequena resultando em curvas decrescentes, ao menos teoricamente. A variação temporal na composição e riqueza de espécies pode resultar em curvas diversas em diferentes anos pois variações climáticas, como uma seca intensa ou um ano muito chuvoso, devem afetar a composição florística e a riqueza de espécies que se estabelecem em ilhas de solo em estágios sucessionais iniciais nos afloramentos rochosos (Houle 1990).

As curvas de riqueza versus área nas ilhas de solo das cangas de Corumbá não permitem rejeitar quaisquer das três principais hipóteses propostas para a interpretação do efeito de insularidade. 
A hipótese de equilíbrio proposta por MacArthur \& Wilson (1967) prevê que o aspecto da curva corresponde à chuva de propágulos disponíveis a quaisquer unidades insulares onde aquelas mais próximas das fontes teriam maior quantidade de espécies. Neste caso, o número de espécies na unidade insular seria reflexo da área e do equilíbrio entre as taxas de colonização e de extinção de espécies nesta ilha. Os valores do parâmetro z refletem o isolamento ou distância da ilha e seus valores estão dentro do previsto por MacArthur \& Wilson 1967 (valores entre 0,20 e 0,35). A Fazenda S.S.Carandá apresentou o maior valor de z, seguida pelas Fazendas Banda Alta e Monjolinho de modo semelhante ao observado pelos valores dos índices de diversidade de Shannon para cada local. Houle (1990) analisou a relação espécie-área em função do estágio sucessional de comunidades de plantas em afloramentos rochosos afirmando que a imigração de novas espécies não seria independente do tamanho da ilha (ilhas maiores possuem uma maior área de interceptação de propágulos), da forma e da sua posição na vertente (ilhas em concavidades possuem maiores chances de receberem propágulos do que locais onde a ação de enxurradas é mais intensa).

A hipótese de heterogeneidade de habitats proposta por Williams (1943) assume uma correlação entre área e número de habitats diferentes pois cada habitat está associado a um grupo diferente de espécies e com o aumento da área novos habitats são incluídos e outros grupos de espécies são encontrados. Assim, os dados empíricos de aumento da riqueza de espécies devido a uma maior heterogeneidade ambiental nas ilhas de solo maiores também podem ser considerados. Um aumento na variedade de habitats pode ser inferido pelas 
relações positivas observadas entre os valores de cobertura e as classes de tamanho, assim como entre o aumento na quantidade de fanerófitas e lianas além da ocorrência de espécies de ambientes mais sombreados que ocorrem nas unidades insulares maiores. As variáveis área e heterogeneidade ambiental estão correlacionadas e assim, estas duas hipóteses não devem ser tomadas como mutuamente exclusivas mas sim complementares (Kallimanis et al. 2008).

A hipótese de amostragem passiva proposta por Coleman et al. (1982) assume que se os indivíduos distribuem-se aleatoriamente em dado local amostras maiores conterão maior número de indivíduos (Connor \& McCoy 19791) e, consequentemente, maior número de espécies, não pode ser rejeitada ao se verificar o aspecto das curvas espécie-área obtidas.

O ajuste aos modelos propostos é compatível com o esperado sob o efeito de dinâmicas de colonização e extinção e de heterogeneidade de habitats entre outras causas prováveis da relação entre riqueza e área (Simberloff 1974). Análises mais detalhadas são necessárias para verificar o efeito de simples interceptação amostral (o aumento da área aumenta a chance de interceptação de espécies) combinado aos outros efeitos prováveis. $\mathrm{O}$ aumento em tamanho propicia maior área de interceptação de sementes, maior heterogeneidade ambiental conferindo melhores condições de sombreamento e maior profundidade de solo assim como condições mais estáveis reduzindo os processos estocásticos. Dessa forma parece não ser possível excluir nenhuma das hipóteses para a relação entre aumento do número de espécies em função do aumento da área. 
- A vegetação em ilhas de solo em função das classes de tamanho

As espécies que definiram a fisionomia das ilhas de solo dos afloramentos ferruginosos foram Deuterocohnia meziana, Bromelia balansae e Selaginella sellowii. Enquanto a primeira espécie revelou maiores valores de cobertura em ilhas pequenas e médias, a segunda apresentou maiores valores de cobertura em ilhas médias a grandes. Estes resultados refletem duas estratégias diferentes na ocupação dos afloramentos. A primeira pode ser descrita pela formação de extensas manchas de D.meziana, muitas vezes descontínuas, e quase homogêneas, podendo se associar a poucas espécies vasculares e ocupar locais onde o escoamento da água da chuva é mais intenso, em locais mais íngremes ou superfícies convexas dos lajedos. A ação do fogo também deve contribuir na descontinuidade destas ilhas já que alguns estolões não sobrevivem à queima. Estas ilhas podem apresentar um formato alongado, em locais com declividade mais acentuada, ou concêntrico, em áreas mais planas. A segunda estratégia pode ser definida pela ocorrência de ilhas de solo com B.balansae associada a componentes arbustivo-arbóreos. Esta espécie não ocorre isoladamente nem em ilhas pequenas. As ilhas de solo com B.balansae geralmente apresentam um formato mais alongado em locais relativamente planos ou côncavos, preenchidos com sedimentos. A pteridófita S.sellowii pode constituir ilhas de solo pequenas, ocorrendo isoladamente, ou ilhas de maior tamanho restringindo-se às bordas. Pode ser considerada uma espécie pioneira importante no processo de sucessão de espécies em ilhas de solo como será discutido posteriormente. 
As espécies arbustivo-arbóreas apresentaram grau de cobertura expressivo somente em ilhas de tamanho intermediário a grande devido às melhores condições microclimáticas nas unidades insulares maiores, como a maior profundidade do solo, maior umidade e heterogeneidade ambiental. Estas condições parecem ser coerentes já que as espécies arbustivo-arbóreas raramente encontram-se de forma isolada ou diretamente sobre a rocha.

As plantas vasculares que se estabeleceram nesses afloramentos com os maiores valores de cobertura nas ilhas pequenas foram aquelas que apresentaram o metabolismo CAM (p.ex. Deuterocohnia meziana) e perda de folhas durante a estação seca (p.ex. Jatropha ribifolia), além de tolerância à dessecação (p.ex. Selaginella sellowii, Selaginella convoluta e Tripogon spicatus) e ainda ciclo de vida curto (p.ex. Staelia sp.). Estas espécies têm sua importância reduzida com o aumento do tamanho insular pois, com o incremento no número de espécies, interações interespecíficas tendem a ser mais atuantes eliminando-as destas comunidades insulares ou restringindo sua ocorrência à bordas das ilhas. Por outro lado, as espécies tolerantes à dessecação Cheilanthes tweediana e Anemia tomentosa apresentaram maiores valores de cobertura em ilhas grandes decorrente de uma associação entre estas plantas e Bromelia balansae. Algumas espécies de Cactaceae parecem restringir sua abundância e cobertura em função do tamanho insular onde, por exemplo, Cereus bicolor só foi registrada em ilhas de solo maiores enquanto Harisia balansae e Opuntia sp. apresentaram maiores valores de cobertura nos tamanhos insulares intermediários, não sendo amostradas em ilhas de tamanho extremo. 


\section{- Aspectos sucessionais nas ilhas de solo em afloramentos rochosos}

\section{ferruginosos}

Obviamente, o curto tempo de observação da dinâmica da vegetação em ilhas de solo nas cangas de Corumbá não permite uma análise temporal adequada dos processos de sucessão mas é possível tecer algumas considerações através da interpretação da variação na composição e cobertura das espécies em função de tamanho insular. Embora alguns conceitos, como a ocorrência de estágios climácicos em afloramentos rochosos, sejam discutíveis é possível inferir que alguns habitats são sequências mais ou menos previsíveis do processo de instalação das comunidades insulares. As unidades insulares podem equivaler a estágios sucessionais relativamente estáveis dentro do processo em curso, onde as ilhas menores corresponderiam a estágios iniciais e as ilhas maiores a estágios finais.

A sucessão se inicia com a colonização da superfície rochosa por cianobactérias e líquens. As plantas vasculares pioneiras devem se estabelecer em microsítios que permitam um pequeno acúmulo de substrato e, aparentemente, a espécie poiquilohídrica Selaginella sellowii seja a principal colonizadora destes ambientes como já foi observado em afloramentos rochosos graníticos do Rio de Janeiro (Meirelles et al. 1999) e na Bolívia (Ibisch et al. 1995). As pequenas e homogêneas manchas de Selaginella acumulam quantidades de substrato suficiente para que outras espécies germinem. Sua forma de crescimento permite, além do acúmulo de substrato, que a água de chuva fique retida nestas manchas por vários 
dias. Espécies litólicas, como Discocactus ferricola, Polycarpaea corymbosa e Gomphrena centrota, não possuem estruturas morfológicas ou forma de crescimento que permitam o acúmulo de substrato para a formação inicial de uma ilha de solo. Outros agrupamentos de vegetação, como manchas de bromélias CAM (Deuterocohnia meziana e Dyckia spp.), podem se formar e o crescimento da moita e a formação de substrato pode se dar de forma concêntrica (Ibisch et al. 1995). Outro estágio seria atingido quando as espécies anuais, como Mimosa nuda, Mimosa xanthocentra, Staelia sp., e espécies tolerantes à dessecação (pteridófitas ou gramíneas) coexistam em ilhas pequenas a intermediárias até que, finalmente, formas perenes arbustivas e arbóreas consigam se estabelecer aumentando sua importância na estrutura destas comunidades insulares. Aparentemente a transição entre as ilhas de vegetação herbáceas para ilhas arbustivas e ilhas florestais seja definida pelo estágio sucessional como já foi sugerido por Sarthou et al. 2009 em afloramentos rochosos graníticos na Guiana Francesa.

Considerando que estes afloramentos sofrem com formas de manejo como gradagem e pastoreio além da ação do fogo mas observa-se posterior recolonização nestes ambientes sugerimos que os processos sucessionais nestes locais não sejam tão lentos quanto os descritos para outros afloramentos rochosos (p.ex. Burbanck \& Platt 1964, Burbanck \& Phillips 1983).

Os processos de sucessão vegetal nos afloramentos graníticos da Bolívia se parecem bastante com os observados nas cangas de Corumbá, inclusive com a ocorrência de ilhas de solo "arbustivas" e "florestais" em depressões largas e a 
presença de Commiphora leptophloeos (Ibisch et al. 1995) como pode-se observar em Corumbá.

Vários mecanismos de sucessão vegetal devem estar atuando, como a facilitação (estabelecimento de espécies de plantas em manchas de Selaginella sellowii, depósito de sedimentos ao redor de tufos de ciperáceas ou gramíneas) e a tolerância (estabelecimento de Bauhinia pentandra dentro de moitas de D.meziana, por exemplo). O estabelecimento aleatório, devido a alta taxa de mudança de espécies em anos ou estações diferentes (Porembski et al. 2000) ou em função da diferença entre afloramentos não foi avaliado. Entretanto, não foi avaliado se as ilhas maiores corresponderiam à estágios mais avançados no processo sucessional ou refletiriam, simplesmente, a heterogeneidade ambiental por ocorrer em locais onde o acúmulo de substrato é mais favorável. De fato, os afloramentos rochosos apresentam condições de não-equilíbrio sucessional e a coexistência de uma variedade de organismos em ambientes sazonal e permanentemente mutáveis o que contribui para explicar o alto grau de diversidade, a despeito de condições ambientais tão restritivas. 


\section{Considerações finais}

Este trabalho foi o primeiro estudo sobre a vegetação sobre afloramentos rochosos ferruginosos em Corumbá, MS, contribuindo com o conhecimento sobre a vegetação sobre cangas do Brasil. Esta vegetação foi composta por elementos oriundos de outras formações vegetais com baixíssimo grau de endemismos. Constatou-se uma grande diferença florística entre os diferentes locais onde cerca de $40 \%$ das espécies foi registrada em um único local.

As duas formas de ocupação da vegetação em afloramentos: estrato herbáceo e ilhas de solo diferiram quanto a composição bem como estrutura além de forma de organização. As espécies do estrato herbáceo podem ocupar ilhas de solo mas quando as unidades insulares são maiores geralmente restringem-se as bordas. Entretanto, as espécies arbustivas-arbóreas que ocorrem nas ilhas de solo não foram registradas sob forma isolada. A espécie Selaginella sellowii destacou-se, em termos de freqüência, dominância e valores de importância tanto nas parcelas quanto nas ilhas de solo.

Verifica-se dois grupos de espécies para o estrato herbáceo, onde o primeiro foi formado por espécies associadas a uma maior proporção de rocha exposta enquanto o segundo constituiu-se por espécies que ocorrem sobre um substrato fino.

Quanto a vegetação em unidades insulares observou-se a segregação entre ilhas com Deuterocohnia meziana e ilhas com Bromelia balansae. O primeiro conjunto 
destacou-se pela associação predominante com espécies herbáceas e, eventualmente, com poucas espécies arbustivo-arbóreas, como Bauhinia pentandra, Astronium fraxinifolium, Jacaranda cuspidifolia ou Talisia esculenta. O segundo conjunto mostrou uma composição florística variada, geralmente associada a componentes arbustivo-arbóreos instaladas em unidades insulares de maior tamanho. As análises de ordenação também mostraram a segregação entre as ilhas de solo com componentes herbáceos daquelas com componentes arbustivoarbóreos para a Fazenda São Sebastião do Carandá, onde não ocorreram ilhas com D.meziana.

Os dados empíricos mostraram uma relação positiva entre o tamanho insular e a área, tanto para o total de unidades amostradas $\left(\mathrm{r}^{2}=0,617\right)$ quanto para as localidades analisadas separadamente. $\mathrm{O}$ melhor ajuste às curvas dos dados entre riqueza e área insular para cada localidade foram a função potência para as Fazendas Banda Alta $\left(\mathrm{r}^{2}=0,639\right)$ e S.S.Carandá $\left(\mathrm{r}^{2}=0,64\right)$ e a função logaríitmica para a Fazenda Monjolinho $\left(\mathrm{r}^{2}=0,522\right)$.

Analisando-se os valores de cobertura em função das classes de tamanho verificou-se que espécies de maior porte apresentaram maiores valores de cobertura em ilhas de maior tamanho enquanto algumas espécies herbáceas reduziram sua importância em ilhas maiores. O grau de cobertura das espécies variou em função das classes de tamanho das ilhas de solo, onde Deuterocohnia meziana mostrou uma cobertura vegetal superior à de Bromelia balansae sendo registrada para todas as classes de tamanhos com uma acentuada redução de cobertura para a classe 7. Já o caraguatá (B.balansae) ocorre em classes de tamanho 
pequeno a grande com incremento nos valores de cobertura para as ilhas de solo maiores. As espécies Selaginella sellowii, Sporobulus monandrus e Staelia sp. mostraram maiores valores de cobertura nas ilhas pequenas e médias, decrescendo em ilhas maiores, enquanto o arbusto Mimosa xanthocentra teve maiores valores em ilhas maiores. As espécies arbustivo-arbóreas ocorrem em ilhas de tamanho maiores, estando ausentes em ilhas pequenas e aumentando os valores de cobertura com o incremento da área.

Este trabalho destaca a importância da conservação destes afloramentos rochosos pela peculiaridade de sua flora, que certamente contribui à biodiversidade regional e ao mosaico de ecossistemas do Pantanal. Urge a mudança nas políticas públicas de preservação que não têm se preocupado com estes ambientes e também a mudança na mentalidade dos proprietários destas áreas que muitas vezes aplicam práticas de manejo inadequadas à conservação da biodiversidade destes afloramentos 


\section{Referências bibliográficas}

ANJOS, E.C. \& OKIDA, R. 2000. Geologia. In Zoneamento ambiental da Borda Oeste do Pantanal: Maciço do Urucum e Adjacências (J.S.V. Silva, ed.). Embrapa, Brasília, p.23-46.

APG. 2003. An update of the Angiosperm Phylogeny Group classification for the orders and families of flowering plants: APG II. Botanical Journal of the Linnean Society v.141,p.399-436.

ARAÚJO, F.S.; OLIVEIRA, R.F. \& LIMA-VERDE, L.W. 2008. Composição, espectro biológico e síndromes de dispersão da vegetação de um inselbergue no domínio da caatinga, Ceará. Rodriguésia, v.59,n.4, p.659-671.

ARRHENIUS, O. 1921. Species and area. The Journal of Ecology, v.9, n.1, p.95-99, set.

BORTOLOTTO, I.M., DAMASCENO-JÚNIOR, G.A. \& ISQUIERDO, S.W.G. 1999. Caracterização das unidades fitofisionômicas da bacia da Lagoa Negra em Ladário - MS. In II Simpósio sobre Recursos Naturais e Sócio-econômicos do Pantanal: manejo e conservação. Brasília, Embrapa, p.283-289.

BRANDÃO, M. \& GAVILANES, M.L. 1990. Mais uma contribuição para o conhecimento da Cadeia do Espinhaço em Minas Gerais (Serra da Piedade) - II. Daphne v.1,n.1,p.26-43. 
BRANDÃO, M. 1992. Caracterização geomorfológica, climática, florística e faunística da Serra do Curral em Belo Horizonte, MG. Daphne v.2,n.2,p.13-38.

BRASIL. 1982. Projeto RADAMBRASIL. Folha SE. 21 Corumbá e parte da folha SE. 20. (Levantamento de recursos naturais, 27). MME, Rio de Janeiro.

BROWN, J.H. \& LOMOLINO, M.V. 2000. Concluding remarks: historical perspective and the future of island biogeography theory.Global Ecology \& Biogeography, v.9, p.87-92.

BRUMMITT, R.K. \& POWELL, C.E. 1992. Authors of plant names. Royal Botanical Gardens, Kew, 732p.

BURBANCK, M.P. \& PHILLIPS, D.L. 1983. Evidence of plant succession on granite outcrops of the Georgia Piedmont. American Midland Naturalist, v.109, n.1, p.94104.

BURBANCK, M.P. \& PLATT, R.B. 1964. Granite outcrop communities of the piedmont plateau in Georgia. Ecology v.45,n.2,p.292-306.

CAIAFA, A.N. \& SILVA, A.F. 2005. Composição florística e espectro biológico de um campo de altitude no Parque Estadual da Serra do Brigadeiro, Minas Gerais, Brasil. Rodriguésia v.56,n.87,p.163-173

CAIAFA, A.N. \& SILVA, A.F. 2007. Structural analysis of the vegetation on a highland granitic rock outcrop in Southeast Brazil. Revista Brasileira de Botânica v.30,n.4,p.657-664. 
CALDEIRA JÚNIOR, C.F.; SOUZA, R.A.; SANTOS, A.M.; SAMPAIO, R.A. \& MARTINS, E.R. 2009. Características químicas do solo e crescimento de Astronium fraxinifolium Schott em área degradada adubada com lodo de esgoto e silicato de cálcio. Revista Ceres, v.56, n.2, p.213-218.

CARDOSO, E.L., OLIVEIRA, H., AMARAL, J.A.M., KER, J.C., PEREIRA, N.R., SANTOS, R.D., TÔSTO, S.G., SPERA, S.T. \& CARVALHO JÚNIOR, W. 2000. Pedologia. In Zoneamento ambiental da borda oeste do Pantanal: maciço do Urucum e adjacências (J.S.V. Silva, org.). Brasília, DF, Embrapa Comunicação para Transferência de Tecnologia, p.95-109.

CASTRO, P.T.A. 2008. Cangas: a influência da geodiversidade na biodiversidade. In: Jacobi, C.M. et al. (org.). I Simpósio: afloramentos ferruginosos no Quadrilátero Ferrífero: biodiversidade, conservação e perspectivas de sustentabilidade. Belo Horizonte: UFMG/ICB.

CLEEF, A. \& SILVA, M.F.F. 1994. Plant communities of the Serra dos Carajás (Pará), Brazil. Boletim do Museu Paraense Emílio Goeldi, série Botânica, v.10, n.2, p.269-281.

COLEMAN, B.D.; MARES, M.A.; WILLIG, M.R. \& HSIEH, Y.-H. 1982. Randomness, area, and species number. Ecology, v.63, p.1121-1133.

COLWELL, R.K. \& CODDINGTON, J.A. 1994. Estimating terrestrial biodiversity through extrapolation. Philosophical Transactions of the Royal Society Lond. B, v.345, p.101-118. 
CONCEIÇÃO, A. 2003. Ecologia da vegetação em afloramentos rochosos na

Chapada Diamantina, Bahia, Brasil. São Paulo: Instituto de Biociências da USP. (Tese de doutorado).

CONCEIÇÃO, A.A. \& GIULIETTI, A.M. 2002. Composição florística e aspectos estruturais de campo rupestre em dois platôs do Morro do Pai Inácio, Chapada Diamantina, Bahia, Brasil. Hoehnea v.29,n.1,p.37-48

CONCEIÇÃO, A.A. \& PIRANI, J.R. 2005. Delimitação de habitats em campos rupestres na Chapada Diamantina, Bahia: substratos, composição florística e aspectos estruturais. Boletim de Botânica da Universidade de São Paulo v.23,n.1,p.85-111.

CONCEIÇÃO, A.A.; GIULIETTI, A.M. \& MEIRELLES, S.T. 2007a. Ilhas de vegetação em afloramentos de quartzito-arenito no Morro do Pai Inácio, Chapada Diamantina, Bahia, Brasil. Acta Botanica Brasilica v.21, n.2, p.335-347

CONCEIÇÃO, A.A.; PIRANI, J.R. \& MEIRELLES, S.T. 2007b. Floristics, structure and soil of insular vegetation in four quartzite-sandstone outcrops of "Chapada Diamantina", northeast Brazil. Revista Brasileira de Botânica v.30, n.4, p.641-656, out.-dez.

CONNOR, E.F. \& McCOY, E.D. 1979. The statistics and biology of the species-area relationship. The American Naturalist, v.113, n.6, p.791-833, jun.

DAMASCENO-JUNIOR, G.A. 2005. Estudo florístico e fitossociológico de um gradiente altitudinal no Maciço Urucum - Mato Grosso do Sul - Brasil. Campinas, SP: Instituto de Biologia da UNICAMP. (Tese de doutorado). 
EGGLI, U. 2002. Synopsis of the Cactaceae of Mato Grosso, Brazil. Haseltonia, n.9, p.146-166

FRANÇA, F., MELO, E., SANTOS, A.K.A., MELO, J.G.A.N., MARQUES, M., SILVA-FILHO, M.F.B., MORAES, L. \& MACHADO, C. 2005. Estudos ecológico e florístico em ilhas de vegetação de um inselberg no semi-árido da Bahia, Brasil. Hoehnea v.32,n.1,p.93-101.

FRANÇA, F.; MELO, E. \& GONÇALVES, J.M. 2006. Aspectos da diversidade da vegetação no topo de um inselbergue no semi-árido da Bahia, Brasil. Sitientibus, série Ciências Biológicas, v.6, n.1, p.30-35

GAFF, D.F. 1987. Desiccation tolerant plants in South America. Oecologia (Berlin) v.74, p.133-136

GAVILANES, M.L. \& BRANDÃO, M. 1991. Flórula da Reserva Biológica Municipal do Poço Bonito, Lavras - MG. II - Formação campo rupestre. Daphne v.2,n.1,p.5-7.

GILBERT, F.S. 1980. The equilibrium theory of island biogeography: fact or fiction? Journal of Biogeography, v.7, p.209-235.

GLEASON, H.A. 1922. On the relationship between species and area. Ecology, v.3, p.158-162.

GRANDI, T.S.M.; SIQUEIRA, J.C. \& PAULA, J.A. 1988. Levantamento florístico da flora fanerogâmica dos campos rupestres da Serra da Piedade, Caeté, Minas Gerais. Pesquisas Botânica, v.39, p.89-104. 
GRÖGER, A. \& HUBER, O. 2007. Rock outcrop habitats in the Venezuelan Guayana lowlands: their main vegetation types and floristic components. Revista Brasileira de Botânica, v.30, n.4, p.599-609, out.-dez.

HAMBLER, D.J. 1964. The vegetation of granitic outcrops in western Nigeria. Journal of Ecology v.52, p.573-594

HARALYI, N.L.E. \& WALDE, D.H.G. 1986. Os minérios de ferro e manganês da região de Urucum, Corumbá, Mato Grosso do Sul. In Principais depósitos minerais do Brasil. Vol. II (C. Schobbenhans \& C.E.S. Coelho, eds.). DNPM, Brasília, p.122-144.

HIRAI, R.Y. \& PRADO, J. 2000. Selaginellaceae Willk. no Estado de São Paulo, Brasil. Revista Brasileira de Botânica, v.23, n.3, p.313-339, set.

HOULE, G. 1990. Species-area relationship during primary succession in granite outcrop plant communities. American Journal of Botany, v.77, n.11, p.1433-1439

HUNTER, J.T. 2003. Persistence on inselbergs: the role of obligate seeders and resprouters. Journal of Biogeography, v.30, p.497-510

IBISCH, P.L., RAUER, G., RUDOLPH, D. \& BARTHLOTT, W. 1995. Floristic, biogeographical, and vegetational aspects of Pre-Cambrian rock outcrops (inselbergs) in eastern Bolivia. Flora v.190,p.299-314.

JACOBI, C.M., CARMO, F.F., VINCENT, R.C. \& STEHMANN, J.R. 2007. Plant communities on ironstone outcrops: a diverse and endangered Brazilian ecosystem. Biodiversity and Conservation v.16,p.2185-2200. 
JACOBI, C.M.; CARMO, F.F. \& VINCENT, R.C. 2008. Estudo fitossociológico de uma comunidade vegetal sobre canga como subsídio para a reabilitação de áreas mineradas no Quadrilátero Ferrífero, MG. Revista Árvore v.32, n.2, p.345-353

KALLIMANIS, A.S.; MAZARIS, A.D.; TZANOPOULOS, J.; HALLEY, J.M., PANTIS, J.D. \& SGARDELIS, S.P. 2008. How does habitat diversity affect the species-area relationship? Global Ecology \& Biogeography, v.17, p.532-538

KILLEEN, T.J. HINZ, P.N. 1992. Grasses of the Precambrian Shield region in eastern lowland Bolivia. I.Habitat preferences. Journal of Tropical Ecology, v.8, p.389-407

KREBS, C.J. 1972. Ecology: the experimental analysis of distribution and abundance. New York: Harper \& Row, 694p.

LEGENDRE, P., LEGENDRE, L. Numerical ecology. 2nd edition. Elsevier. 1998.

LOMOLINO, M.V. \& WEISER, M.D. 2001. Towards a more general species-area relationship: diversity on all islands, great and small. Journal of Biogeography, v.28, p.431-445

LOMOLINO, M.V. 2000. A species-based theory of insular zoogeography. Global Ecology \& Biogeography, v.9, p.39-58.

MacARTHUR, R.H. \& WILSON, E.O. 1963. An equilibrium theory of insular zoogeography. Evolution, v.17, n.4, p.373-387, dez.

MacARTHUR, R.H. \& WILSON, E.O. 1967. The theory of Island Biogeography. New Jersey: Princeton University Press. 203p. 
MEDINA, B.M.O., RIBEIRO, K.T. \& SCARANO, F.R. 2006. Plant-plant and planttopography interactions on a rock outcrop at high altitude in southeastern Brazil. Biotropica v.38,n.1,p.27-34.

MEIRELLES, S.T. 1990. Ecologia da vegetação de afloramentos rochosos do litoral da região sudeste. Campinas: Instituto de Biologia da UNICAMP. (Dissertação de mestrado).

MEIRELLES, S.T. 1996. Estrutura da comunidade e características funcionais dos componentes da vegetação de um afloramento rochoso em Atibaia, SP. São Carlos: Centro de Ciências Biológicas e da Saúde da UFSCar. (Tese de doutorado). MEIRELLES, S.T., PIVELLO, V.R. \& JOLY, C.A. 1999. The vegetation of granite rock outcrops in Rio de Janeiro, Brazil, na the need for its protection. Environmental Conservation v.26,n.1,p.10-20.

MICHELANGELI, F.A. 2000. Species composition and species-area relationships in vegetation isolates on the summit of a sandstone mountain in southern Venezuela. Journal of Tropical Ecology, v.16, p.69-82

MOSTACEDO, B.; TOLEDO, M \& FREDERICKSEN, T.S. 2001. La vegetación de las lajas en la región de Lomerío, Santa Cruz, Bolivia. Acta Amazonica, v.31, n.1, p.11-25

MOURÃO, A. \& STEHMANN, J.R. 2007. Levantamento da flora do campo rupestre sobre canga hematítica couraçada remanescente na Mina do Brucutu, Barão de Cocais, Minas Gerais, Brasil. Rodriguésia v.58,n.4,p.775-786. 
Mueller-Dombois, D. \& Ellenberg, H. 1974. Aims and methods of vegetation ecology. New York: Willey. 547p.

NEVES, S.P.S. \& CONCEIÇÃO, A.A. 2007. Vegetação em afloramentos rochosos na Serra do Sincorá, Chapada Diamantina, Bahia, Brasil. Sitientibus série Ciências Biológicas v.7, n.1, jan.-mar., p.36-45

OLIVEIRA, R.B. \& GODOY, S.A.P. 2007. Composição florística dos afloramentos rochosos do Morro do Forno, Altinópolis, São Paulo. Biota Neotropica 7(2) http:/ / www.biotaneotropica.org.br/v7n2/pt/abstract?article+bn00507022007

PHILLIPS, D.L. 1981. Succession in granite outcrop shrub-tree communities.The American Midland Naturalist, v.106, n.2, p.313-317

POREMBSKI, S. \& BARTHLOTT, W. 2000. Granitic and gneissic outcrops (inselbergs) as centers of diversity for desiccation-tolerant vascular plants. Plant Ecology v.151,p.19-28.

POREMBSKI, S. \& BARTHLOTT, W. 2000. Granitic and gneissic outcrops (inselbergs) as centers of diversity for desiccation-tolerant vascular plants. Plant Ecology, v.151, p.19-28

POREMBSKI, S. 2007. Tropical inselbergs: habitat types, adaptative strategies and diversity patterns. Revista Brasileira de Botânica v.30,n.4,p.579-586.

POREMBSKI, S., MARTINELLI, G., OHLEMÜLLER, R. \& BARTHLOTT, W. 1998. Diversity and ecology of saxicolous vegetation mats on inselbergs in the Brazilian Atlantic rainforest. Diversity and Distributions v.4,p.107-119. 
POREMBSKI, S.; BROWN, G. \& BARTHLOTT, W. 1995. An inverted latitudinal gradient of plant diversity in shallow depressions on Ivorian inselbergs.Vegetatio, v.117, p. 151-163

POREMBSKI, S.; SEINE, R. \& BARTHLOTT, W. 1997. Inselberg vegetation and the biodiversity of granite outcrops. Journal of the Royal Society of Western Australia, v.80, p.193-199.

POREMBSKI, S.; SZARZYNSKI,J.; MUND, J.P. \& BARTHLOTT, W. 1996. Biodiversity and vegetation of small-sized inselbergs in a West African rain forest (Taï, Ivory Coast). Journal of Biogeography, v.23, p.47-55

POTT, A., SILVA, J.S.V., SALIS, S.M., POTT, V.J. \& SILVA, M.P. 2000. Vegetação e uso da terra. In Zoneamento ambiental da borda oeste do Pantanal: maciço do Urucum e adjacências (J.S.V. Silva, org.). Brasília, DF, Embrapa Comunicação para Transferência de Tecnologia, p.111-131.

RAGUSA-NETTO, J. \& SILVA, R.R. 2007. Canopy phenology of a dry forest in western. Brazil. Braz.J.Biol., v.67, n.3, p.569-575

RAUNKIAER, C. 1934. The life forms of plants and and statistical plant geography. Oxford: Clarendon Press. 147p.

RAYOL, B.P. 2006. Análise florística e estrutural da vegetação xerofítica das savanas metalófilas na Floresta Nacional de Carajás: subsídios à conservação. Dissertação de Mestrado, Universidade Rural da Amazônia e Museu Paraense Emílio Goeldi, Pará. 
RIBEIRO, K.T. \& MEDINA, B.M.O. 2002. Estrutura,dinâmica e biogeografia das ilhas de vegetação sobre rocha do Planalto do Itatiaia, RJ. Boletim do Parque Nacional do Itatiaia, v.10, p.1-82.

RIBEIRO, K.T., MEDINA, B.M.O. \& SCARANO, F.R. 2007. Species composition and biogeographic relations of the rock outcrop flora on the high plateau of Itatiaia, SE-Brazil. Revista Brasileira de Botânica v.30,n.4,p.623-639.

RIZZINI, C.T. 1997. Tratado de fitogeografia do Brasil: aspectos ecológicos, sociológicos e florísticos. Âmbito Cultural Edições Ltda., Rio de Janeiro, 2.ed.

SANTOS, M.G. SYLVESTRE, L.S. 2006. Aspectos florísticos e econômicos das pteridófitas de um afloramento rochoso no Estado do Rio de Janeiro, Brasil. Acta Botanica Brasilica, v.20, n.1, p.115-124

SARTHOU, C. VILLIERS, J.-F. 1998. Epilithic plant communities on inselbergs in French Guiana. Journal of Vegetation Science, v.9, p.847-860

SARTHOU, C.; KOUNDA-KIKI, C.; VAÇULIK, A.; MORA, P. \& PONGE, J.-F. 2009. Successional patterns on tropical inselbergs: A case study on the Nouragues inselberg (French Guiana). Flora, v.204, p.396-407.

SARTHOU, C.; VILLIERS, J.F. \& PONGE, J.F. 2003. Shrub vegetation on tropical granitic inselbergs in French Guiana. Journal of Vegetation Science, v14,p.645-652 SCARANO, F.R. 2002. Structure, function and floristic relationships of plant communities in stressful habitats marginal to the Brazilian Atlantic Rainforest. Annals of Botany, v.90, p.517-524. 
SCARANO, F.R.; DUARTE, H.M.; FRANCO, A.C.; GEBLER, A.; MATTOS, E.A.; RENNENBERG, H. \& LÜTTGE, U. 2004. Physiological synecology of tree species in relation to geographic distribution and ecophysiological parameters at the Atlantic forest periphery in Brazil: an overview. Trees, v.19, p.493-496

SCHEINER, S.M. 2003. Six types of species-area curves. Global Ecology \& Biogeography, v.12, p.441-447.

SECCO, R.S. \& LOBO, M.G.A. 1988. Considerações taxonômicas e ecológicas sobre a flora do "campos rupestres" da Serra dos Carajás (PA). Boletim da FBCN, Rio de Janeiro, v.23, p.30-44.

SECCO, R.S. \& MESQUITA, A.L. 1983. Notas sobre a vegetação de canga na Serra Norte - I. Boletim do Museu Paraense Emílio Goeldi v.59,p.1-13.

SHURE, D. \& RAGSDALE, H.L. 1977. Patterns of primary succession on granite outcrop surfaces. Ecology, v.58, p.993-1006

SILVA, L.A.C. 2008. Qualidade de sementes da grama-do-cerrado (Mesosetum chaseae Luces) na sub-região da Nhecolândia, Pantanal, MS. Botucatu: Faculdade de Medicina Veterinária e Zootecnia, UNESP. (Dissertação de Mestrado).

SILVA, M.F.F. 1991. Anállise florística da vegetação que cresce sobre canga hematítica em Carajás - Pará (Brasil). Boletim do Museu Paraense Emílio Goeldi, série Botânica v.7,n.1,p.79-107. 
SILVA, M.F.F., SECCO, R.S. \& LOBO, M.G. 1996. Aspectos ecológicos da vegetação rupestre da Serra dos Carajás, Estado do Pará, Brasil. Acta Amazonica v.26,n.1/2,p.17-44.

SILVA, R.R. \& TOZZI, A.M.G.A. 2008. A new species of Lonchocarpus (Leguminosae, Papilionoideae) from Mato Grosso do Sul, Brazil. Brittonia, v.60, n.1, p.34-37.

SILVA, R.R. 2006. Leguminosae no Planalto Residual do Urucum, oeste do Pantanal do Mato Grosso do Sul, Brasil: inventário, taxonomia e similaridade florística. Campinas, SP: Instituto de Biologia da UNICAMP. (Tese de doutorado). SIMBERLOFF, D.S. 1974. Equilibrium theory of island biogeography and ecology. Annual Review of Ecology and Systematics, v.5, p.161-182

SORIANO, B.M.A. 2000. Climatologia. In Zoneamento ambiental da borda oeste do Pantanal: maciço do Urucum e adjacências (J.S.V. SILVA, org.). Brasília, DF, Embrapa Comunicação para Transferência de Tecnologia, p.69-81.

VIANA, P.L. \& LOMBARDI, J.A. 2007. Florística e caracterização dos campos rupestres sobre canga na Serra da Calçada, Minas Gerais, Brasil. Rodriguesia v.58,n.1,p.159-177.

VINCENT, R.C. \&MEGURO, M. 2008. Influence of soil properties on the abundance of plant species in ferruginous rocky soils vegetation, southeastern Brazil. Revista Brasileira de Botânica, v.31, n.3, p.377-388, jul.-set. 
VINCENT, R.C. 2004. Florística, fitossociologia e relações entre a vegetação e o solo em áreas de campos ferruginosos no Quadrilátero Ferrífero, Minas Gerais. Tese de doutorado, Universidade de São Paulo, São Paulo.

WALDEMAR, C.C. 1998. A vegetação rupestre heliófila do Parque Estadual de Itapuã, Viamão, RS. Dissertação de mestrado, UFRGS, Rio Grande do Sul.

WHITTAKER, R.J. 1998. Island Biogeography: ecology, evolution, and conservation. Oxford, Inglaterra: Oxford University Press, 1998. 285p. Oxford, Inglaterra: Oxford University Press, 1998. 285p.

WILLIAMS, C.B. 1943. Area and number of species. Nature, v.152, p.264-267, set.4 www.dnpm.gov.br (acesso em 30 de maio de 2009)

WYATT, R. \& FOWLER, N. 1977. The vascular flora and vegetation of the North Carolina granite outcrops. Bulletin of the Torrey Botanical Club, v. 104, n.3, p.245-253, jul-set.

ZAR, J.H. 1974. Biostatistical analysis. USA: Prentice-Hall, 620p. 


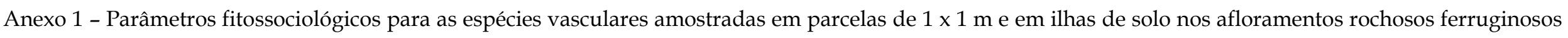

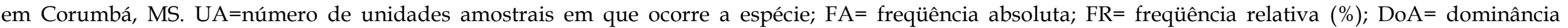

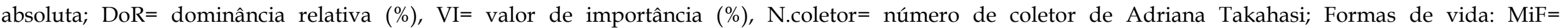
microfanerófita, $\mathrm{NF}=$ nanofanerófita, $\mathrm{L}=$ liana, $\mathrm{H}=$ hemicriptófita, $\mathrm{C}=$ caméfita, $\mathrm{T}=$ terófita, $\mathrm{G}=$ geófita, $\mathrm{S}=$ suculenta, $\mathrm{E}=$ epífita

\begin{tabular}{|c|c|c|c|c|c|c|c|c|c|}
\hline $\begin{array}{l}\text { FAMÍLIA } \\
\text { Espécie }\end{array}$ & $\begin{array}{c}\text { Tipo } \\
\text { amostragem }\end{array}$ & UA & FA & FR & DoA & DoR & VI & N.coletor & $\begin{array}{c}\text { Forma } \\
\text { vida }\end{array}$ \\
\hline \multicolumn{10}{|l|}{ ACANTHACEAE } \\
\hline Anisacanthus boliviensis (Nees) Wassh. & Ilha & 4 & 2,4390 & 0,1607 & 0,0001 & 0,0117 & 0,0862 & 1396 & $\mathrm{NF}$ \\
\hline Ruellia ciliatiflora Hook. & Ilha & 1 & 0,6098 & 0,0402 & 0,0002 & 0,0175 & 0,0288 & 1032 & NF \\
\hline \multicolumn{10}{|l|}{ AMARANTHACEAE } \\
\hline Gomphrena centrota E. Holzh. & Ilha & 10 & 6,0976 & 0,4018 & 0,0005 & 0,0541 & 0,2279 & 1040 & $\mathrm{C}$ \\
\hline Gomphrena centrota E. Holzh. & Parcela & 20 & 10,0503 & 1,48148 & 0,0071 & 0,71302 & 1,0973 & 1040 & $\mathrm{C}$ \\
\hline Gomphrena vaga Mart. & Ilha & 5 & 3,0488 & 0,2009 & 0,0002 & 0,0248 & 0,1128 & 1051 & $\mathrm{~L}$ \\
\hline Gomphrena sp. & Ilha & 1 & 0,6098 & 0,0402 & 0,0004 & 0,0400 & 0,0401 & 1457 & $\mathrm{~L}$ \\
\hline \multicolumn{10}{|l|}{ AMARYLLIDACEAE } \\
\hline Zephyranthes cearensis (Herb.)Baker & Parcela & 7 & 3,51759 & 0,51852 & 0,0015 & 0,14994 & 0,3342 & 947 & G \\
\hline \multicolumn{10}{|l|}{ ANACARDIACEAE } \\
\hline Astronium fraxinifolium Schott & Ilha & 52 & 31,7073 & 2,0892 & 0,0510 & 5,0983 & 3,5938 & 1474 & $\mathrm{MiF}$ \\
\hline Myracrodruon urundeuva Allemão & Ilha & 10 & 6,0976 & 0,4018 & 0,0063 & 0,6316 & 0,5167 & 1423 & $\mathrm{MiF}$ \\
\hline \multicolumn{10}{|l|}{ ANNONACEAE } \\
\hline Annona nutans (R.E. Fr.) R.E. Fr. & Ilha & 7 & 4,2683 & 0,2812 & 0,0008 & 0,0760 & 0,1786 & 964 & $\mathrm{MiF}$ \\
\hline \multicolumn{10}{|l|}{ APOCYNACEAE } \\
\hline Aspidosperma pyrifolium Mart. & Ilha & 4 & 2,4390 & 0,1607 & 0,0082 & 0,8151 & 0,4879 & 1120 & $\mathrm{MiF}$ \\
\hline Aspidosperma quirandy Hassl. & Ilha & 2 & 1,2195 & 0,0804 & 0,0008 & 0,0757 & 0,0780 & 698 & $\mathrm{MiF}$ \\
\hline
\end{tabular}


continuação Anexo 1

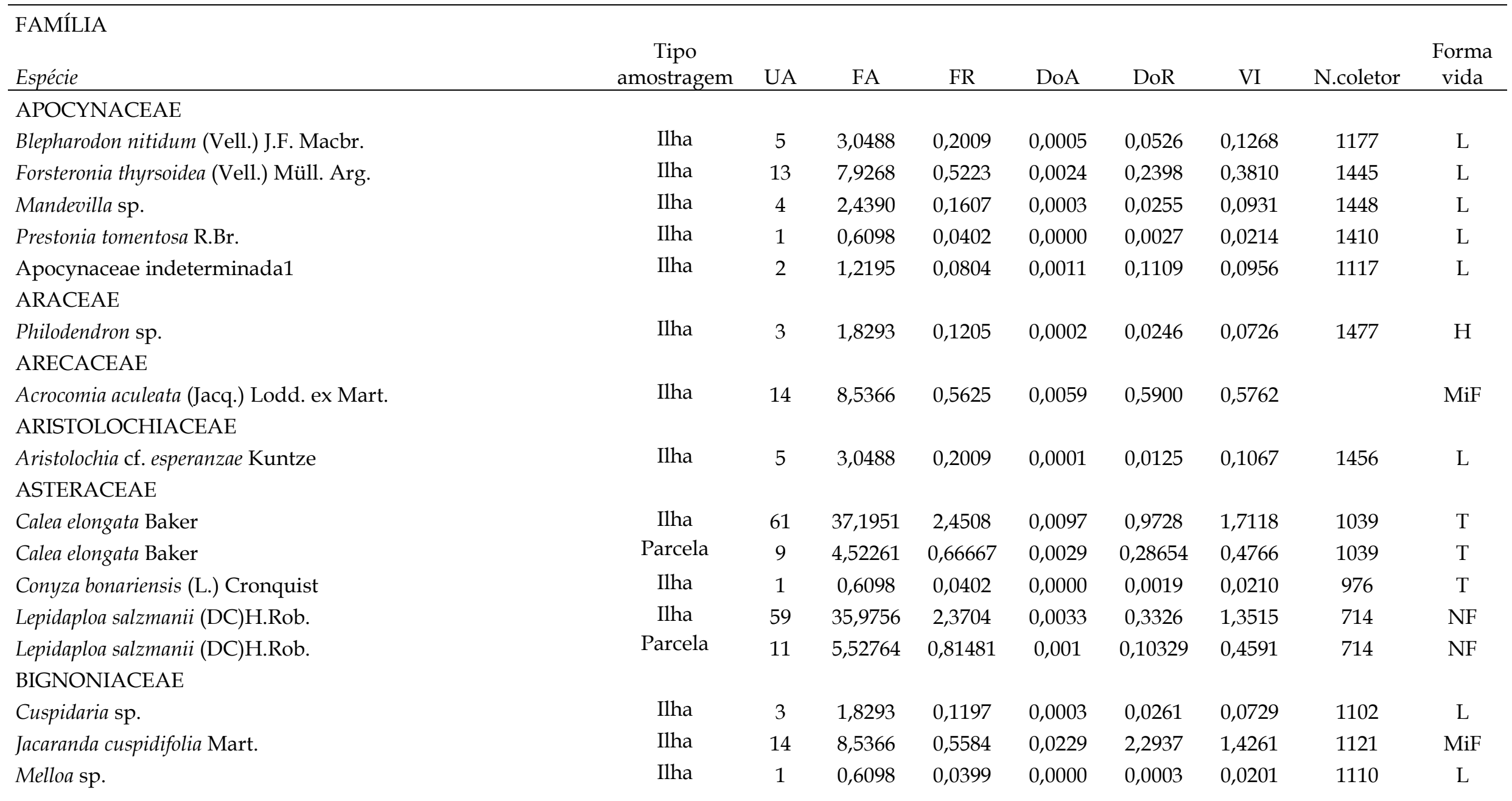




\begin{tabular}{|c|c|c|c|c|c|c|c|c|c|}
\hline $\begin{array}{l}\text { FAMÍLIA } \\
\text { Espécie }\end{array}$ & $\begin{array}{c}\text { Tipo } \\
\text { amostragem }\end{array}$ & UA & FA & FR & DoA & DoR & VI & N.coletor & $\begin{array}{c}\text { Forma } \\
\text { vida }\end{array}$ \\
\hline \multicolumn{10}{|l|}{ BIGNONIACEAE } \\
\hline Bignoniaceae1 & Ilha & 2 & 1,2195 & 0,0798 & 0,0001 & 0,0111 & 0,0454 & 1443 & $\mathrm{~L}$ \\
\hline \multicolumn{10}{|l|}{ BIXACEAE } \\
\hline Cochlospermum regium (Schrank) Pilg. & Ilha & 4 & 2,4390 & 0,1596 & 0,0011 & 0,1056 & 0,1326 & 705 & $\mathrm{NF}$ \\
\hline Cleome eosina J.F. Macbr. & Ilha & 18 & 10,9756 & 0,7180 & 0,0027 & 0,2688 & 0,4934 & 829 & $\mathrm{~T}$ \\
\hline Cleome eosina J.F. Macbr. & Parcela & 3 & 1,50754 & 0,22222 & 0,0007 & 0,0733 & 0,1478 & 829 & $\mathrm{~T}$ \\
\hline Cleome guianensis Aubl. & Ilha & 10 & 6,0976 & 0,3989 & 0,0004 & 0,0399 & 0,2194 & 780 & $\mathrm{~T}$ \\
\hline Cleome guianensis Aubl. & Parcela & 23 & 11,5578 & 1,7037 & 0,0036 & 0,35651 & 1,0301 & 780 & $\mathrm{~T}$ \\
\hline \multicolumn{10}{|l|}{ BROMELIACEAE } \\
\hline Bromelia balansae Mez & Ilha & 60 & 36,5854 & 2,3933 & 0,2407 & 24,0665 & 13,2299 & 1475 & $\mathrm{H}$ \\
\hline \multicolumn{10}{|l|}{ BURSERACEAE } \\
\hline Commiphora leptophloeos (Mart.) J.B. Gillett & Ilha & 29 & 17,6829 & 1,1568 & 0,0401 & 4,0105 & 2,5836 & 729 & $\mathrm{MiF}$ \\
\hline \multicolumn{10}{|l|}{ CACTACEAE } \\
\hline Cereus bicolor Rizzini \& Mattos & Ilha & 19 & 11,5854 & 0,7579 & 0,0103 & 1,0294 & 0,8936 & 1376 & $\mathrm{MiF}$ \\
\hline Discocactus ferricola Buining \& Brederoo & Ilha & 35 & 21,3415 & 1,3961 & 0,0014 & 0,1357 & 0,7659 & 845 & $\mathrm{~s}$ \\
\hline Discocactus ferricola Buining \& Brederoo & Parcela & 23 & 11,5578 & 1,7037 & 0,0115 & 1,1495 & 1,4266 & 845 & S \\
\hline
\end{tabular}




\begin{tabular}{|c|c|c|c|c|c|c|c|c|c|}
\hline $\begin{array}{l}\text { FAMÍLIA } \\
\text { Espécie }\end{array}$ & $\begin{array}{c}\text { Tipo } \\
\text { amostragem }\end{array}$ & UA & FA & FR & DoA & DoR & VI & N.coletor & $\begin{array}{l}\text { Forma } \\
\text { vida }\end{array}$ \\
\hline \multicolumn{10}{|l|}{ CACTACEAE } \\
\hline Frailea cataphracta (Dams) Britton \& Rose & Ilha & 1 & 0,6098 & 0,0399 & 0,0000 & 0,0002 & 0,0200 & 779 & $S$ \\
\hline Harrisia balansae (K. Schum.) N.P. Taylor \& Zappi & Ilha & 9 & 5,4878 & 0,3590 & 0,0034 & 0,3422 & 0,3506 & 755 & $S$ \\
\hline Opuntia sp. & Ilha & 5 & 3,0488 & 0,1994 & 0,0008 & 0,0777 & 0,1386 & 672 & $S$ \\
\hline Praecereus euchlorus (F.A.C. Weber) N.P. Taylor & Ilha & 16 & 9,7561 & 0,6382 & 0,0022 & 0,2168 & 0,4275 & 1103 & $S$ \\
\hline \multicolumn{10}{|l|}{ CANNABACEAE } \\
\hline Celtis pubescens Spreng. & Ilha & 4 & 2,4390 & 0,1596 & 0,0019 & 0,1925 & 0,1760 & 1346 & $\mathrm{MiF}$ \\
\hline \multicolumn{10}{|l|}{ CARYOPHYLLACEAE } \\
\hline Polycarpaea corymbosa (L.) Lam. & Ilha & 31 & 18,9024 & 1,2365 & 0,0006 & 0,0620 & 0,6493 & 973 & $\mathrm{~T}$ \\
\hline Polycarpaea corymbosa (L.) Lam. & Parcela & 15 & 7,53769 & 1,11111 & 0,0019 & 0,18992 & 0,6505 & 973 & $\mathrm{~T}$ \\
\hline \multicolumn{10}{|l|}{ COMBRETACEAE } \\
\hline Combretum duarteanum Cambess. & Ilha & 6 & 3,6585 & 0,2393 & 0,0137 & 1,3704 & 0,8049 & 941 & $\mathrm{MiF}$ \\
\hline Combretum leprosum Mart. & Ilha & 2 & 1,2195 & 0,0798 & 0,0012 & 0,1168 & 0,0983 & 766 & $\mathrm{MiF}$ \\
\hline Terminalia argentea Mart. & Ilha & 1 & 0,6098 & 0,0399 & 0,0002 & 0,0219 & 0,0309 & 1044 & $\mathrm{MiF}$ \\
\hline \multicolumn{10}{|l|}{ COMMELINACEAE } \\
\hline Commelina sp. & Ilha & 33 & 20,1220 & 1,3163 & 0,0031 & 0,3090 & 0,8127 & 1004 & NF \\
\hline Tripogandra glandulosa (Seub.) Rohweder & Ilha & 2 & 1,2195 & 0,0798 & 0,0000 & 0,0045 & 0,0421 & 1186 & $\mathrm{C}$ \\
\hline \multicolumn{10}{|l|}{ CONVOLVULACEAE } \\
\hline Evolvulus alopecuroides Mart. & Ilha & 3 & 1,8293 & 0,1197 & 0,0001 & 0,0111 & 0,0654 & 1383 & NF \\
\hline Evolvulus alopecuroides Mart. & Parcela & 14 & 7,03518 & 1,03704 & 0,0018 & 0,17659 & 0,6068 & 1383 & NF \\
\hline Evolvulus filipes Mart. & Ilha & 1 & 0,6098 & 0,0399 & 0,0000 & 0,0003 & 0,0201 & 1203 & NF \\
\hline Evolvulus filipes Mart. & Parcela & 5 & 2,51256 & 0,37037 & 0,0002 & 0,02332 & 0,1968 & 1203 & NF \\
\hline
\end{tabular}




\begin{tabular}{|c|c|c|c|c|c|c|c|c|c|}
\hline $\begin{array}{l}\text { FAMÍLIA } \\
\text { Espécie }\end{array}$ & $\begin{array}{c}\text { Tipo } \\
\text { amostragem }\end{array}$ & UA & FA & FR & DoA & DoR & VI & N.coletor & $\begin{array}{c}\text { Forma } \\
\text { vida }\end{array}$ \\
\hline \multicolumn{10}{|l|}{ CONVOLVULACEAE } \\
\hline Jacquemontia evolvuloides (Moric.) Meissn. & Ilha & 39 & 23,7805 & 1,5556 & 0,0047 & 0,4739 & 1,0148 & 1125 & $\mathrm{~L}$ \\
\hline Jacquemontia fruticulosa Hallier $\mathrm{f}$. & Parcela & 1 & 0,50251 & 0,07407 & $3 \mathrm{E}-05$ & 0,00333 & 0,0387 & 940 & NF \\
\hline Jacquemontia fruticulosa Hallier $\mathrm{f}$. & Ilha & 19 & 11,5854 & 0,7579 & 0,0005 & 0,0495 & 0,4037 & 940 & NF \\
\hline \multicolumn{10}{|l|}{ CUCURBITACEAE } \\
\hline \multicolumn{10}{|l|}{ CYPERACEAE } \\
\hline Cyperus aggregatus (Willd.) Endl. & Ilha & 57 & 34,7561 & 2,2736 & 0,0015 & 0,1545 & 1,2140 & 1363 & $\mathrm{H}$ \\
\hline Cyperus aggregatus (Willd.) Endl. & Parcela & 37 & 18,593 & 2,74074 & 0,0067 & 0,67437 & 1,7076 & 1363 & $\mathrm{H}$ \\
\hline Cyperus cornelii-ostenii Kük. & Ilha & 8 & 4,8780 & 0,3191 & 0,0003 & 0,0253 & 0,1722 & 1343 & $\mathrm{H}$ \\
\hline Cyperus cornelii-ostenii Kük. & Parcela & 5 & 2,51256 & 0,37037 & 0,001 & 0,09662 & 0,2335 & 1343 & $\mathrm{H}$ \\
\hline Cyperus laxus Lam. & Ilha & 1 & 0,6098 & 0,0399 & 0,0001 & 0,0052 & 0,0225 & 1263 & $\mathrm{H}$ \\
\hline Cyperus uncinulatus Poir. & Parcela & 41 & 20,603 & 3,03704 & 0,0392 & 3,92497 & 3,481 & 1129 & $\mathrm{H}$ \\
\hline Fimbristylis sp. & Parcela & 9 & 4,52261 & 0,66667 & 0,0013 & 0,12994 & 0,3983 & 1338 & $\mathrm{H}$ \\
\hline Kyllinga odorata Vahl & Ilha & 3 & 1,8293 & 0,1197 & 0,0001 & 0,0059 & 0,0628 & 1268 & $\mathrm{H}$ \\
\hline Kyllinga odorata Vahl & Parcela & 4 & 2,01005 & 0,2963 & 0,0009 & 0,08663 & 0,1915 & 1268 & $\mathrm{H}$ \\
\hline \multicolumn{10}{|l|}{ ERYTHROXYLACEAE } \\
\hline Erythroxylum deciduum A. St.-Hil. & Ilha & 9 & 5,4878 & 0,3590 & 0,0087 & 0,8692 & 0,6141 & 1316 & NF \\
\hline Erythroxylum sp. & Ilha & 4 & 2,4390 & 0,1596 & 0,0009 & 0,0904 & 0,1250 & 1454 & NF \\
\hline
\end{tabular}




\begin{tabular}{|c|c|c|c|c|c|c|c|c|c|}
\hline $\begin{array}{l}\text { FAMÍLIA } \\
\text { Espécie }\end{array}$ & $\begin{array}{c}\text { Tipo } \\
\text { amostragem }\end{array}$ & UA & FA & FR & DoA & DoR & VI & N.coletor & $\begin{array}{c}\text { Forma } \\
\text { vida }\end{array}$ \\
\hline \multicolumn{10}{|l|}{ EUPHORBIACEAE } \\
\hline Acalypha communis Müll. Arg. & Ilha & 2 & 1,2195 & 0,0798 & 0,0000 & 0,0037 & 0,0417 & 1022 & NF \\
\hline Actinostemon communis (Müll. Arg.) Pax & Ilha & 1 & 0,6098 & 0,0399 & 0,0001 & 0,0126 & 0,0263 & 1068 & NF \\
\hline Cnidioscolus urens L. & Ilha & 5 & 3,0488 & 0,1994 & 0,0016 & 0,1622 & 0,1808 & 1304 & $\mathrm{MiF}$ \\
\hline Croton pedicellaltus Kunth & Ilha & 4 & 2,4390 & 0,1596 & 0,0003 & 0,0253 & 0,0924 & 943 & C \\
\hline Croton pedicellaltus Kunth & Parcela & 7 & 3,51759 & 0,51852 & 0,0011 & 0,10662 & 0,3126 & 943 & C \\
\hline Croton glandulosus L. & Ilha & 4 & 2,4391 & 0,1596 & 0,0003 & 0,0279 & 0,0937 & 1185 & NF \\
\hline Dalechampia brasiliensis Lam. & Ilha & 4 & 2,4390 & 0,1596 & 0,0005 & 0,0501 & 0,1048 & 985 & $\mathrm{~L}$ \\
\hline Jatropha ribifolia (Pohl) Baill. & Ilha & 20 & 12,1951 & 0,7978 & 0,0154 & 1,5375 & 1,1676 & 1026 & NF \\
\hline Jatropha weddelliana Baill. & Ilha & 1 & 0,6098 & 0,0399 & 0,0000 & 0,0008 & 0,0203 & 673 & $\mathrm{NF}$ \\
\hline Manihot anomala Pohl & Ilha & 1 & 0,6098 & 0,0399 & 0,0026 & 0,2622 & 0,1511 & 767 & NF \\
\hline \multicolumn{10}{|l|}{ FABACEAE } \\
\hline Aeschnomene histrix Poir. & Ilha & 59 & 35,9756 & 2,3534 & 0,0045 & 0,4510 & 1,4022 & 925 & NF \\
\hline Aeschnomene histrix Poir. & Parcela & 60 & 30,1508 & 4,44444 & 0,0156 & 1,55932 & 3,0019 & 925 & NF \\
\hline Alysicarpus vaginalis (L.) DC. & Ilha & 12 & 7,3171 & 0,4787 & 0,0006 & 0,0636 & 0,2711 & 1019 & NF \\
\hline Alysicarpus vaginalis (L.) DC. & Parcela & 8 & 4,0201 & 0,59259 & 0,0007 & 0,0733 & 0,3329 & 1019 & NF \\
\hline Amburana cearensis (Allemão) A.C. Sm. & Ilha & 19 & 11,5854 & 0,7579 & 0,0211 & 2,1091 & 1,4335 & 1122 & $\mathrm{MiF}$ \\
\hline Anadenanthera colubrina (Vell.) Brenan & Ilha & 14 & 8,5366 & 0,5584 & 0,0158 & 1,5814 & 1,0699 & 1473 & $\mathrm{MiF}$ \\
\hline Bauhinia pentandra (Bong.) Vogel ex Steud. & Ilha & 55 & 33,5366 & 2,1939 & 0,0176 & 1,7632 & 1,9785 & 961 & $\mathrm{MiF}$ \\
\hline Bauhinia pentandra (Bong.) Vogel ex Steud. & Parcela & 1 & 0,50251 & 0,07407 & 7E-05 & 0,00666 & 0,0404 & 961 & $\mathrm{MiF}$ \\
\hline Camptosema ellipticum (Desv.) Burkart & Ilha & 16 & 9,7561 & 0,6382 & 0,0018 & 0,1832 & 0,4107 & 1041 & $\mathrm{~L}$ \\
\hline Camptosema ellipticum (Desv.) Burkart & Parcela & 1 & 0,50251 & 0,07407 & 7E-05 & 0,00666 & 0,0404 & 1041 & $\mathrm{~L}$ \\
\hline Camptosema sp. & Ilha & 3 & 1,8293 & 0,1197 & 0,0000 & 0,0032 & 0,0614 & 1093 & $\mathrm{~L}$ \\
\hline
\end{tabular}




\begin{tabular}{|c|c|c|c|c|c|c|c|c|c|}
\hline $\begin{array}{l}\text { FAMÍLIA } \\
\text { Espécie }\end{array}$ & $\begin{array}{c}\text { Tipo } \\
\text { amostragem }\end{array}$ & UA & FA & FR & DoA & DoR & VI & N.coletor & $\begin{array}{c}\text { Forma } \\
\text { vida }\end{array}$ \\
\hline \multicolumn{10}{|l|}{ FABACEAE } \\
\hline Centrosema pascuorum Mart. ex Benth. & Ilha & 2 & 1,2195 & 0,0798 & 0,0001 & 0,0098 & 0,0448 & 1373 & $\mathrm{~L}$ \\
\hline Centrosema pascuorum Mart. ex Benth. & Parcela & 2 & 1,00503 & 0,14815 & 1E-04 & 0,01 & 0,0791 & 1373 & $\mathrm{~L}$ \\
\hline Chamaecrista flexuosa (L.) Greene & Ilha & 3 & 1,8293 & 0,1197 & 0,0005 & 0,0523 & 0,0860 & 1107 & NF \\
\hline Chamaecrista flexuosa (L.) Greene & Parcela & 11 & 5,52764 & 0,81481 & 0,0021 & 0,20991 & 0,5124 & 1107 & NF \\
\hline Chamaecrista serpens (L.) Greene & Parcela & 4 & 2,01005 & 0,2963 & 0,0004 & 0,04331 & 0,1698 & 1006 & $\mathrm{C}$ \\
\hline Guibourtia hymenaefolia (Moric.) J. Léonard & Ilha & 16 & 9,7561 & 0,6382 & 0,0151 & 1,5061 & 1,0721 & 1314 & $\mathrm{MiF}$ \\
\hline Lonchocarpus variabilis R.R.Silva \& A.M.G.Azevedo & Ilha & 1 & 0,6098 & 0,0399 & 0,0000 & 0,0009 & 0,0204 & 1137 & $\mathrm{MiF}$ \\
\hline Macroptilium lathyroides (L.) Urb. & Ilha & 2 & 1,2195 & 0,0798 & 0,0000 & 0,0038 & 0,0418 & 1011 & $\mathrm{~L}$ \\
\hline Mimosa bimucronata (DC.) Kuntze var.bimucronata & Ilha & 6 & 3,6585 & 0,2393 & 0,0047 & 0,4746 & 0,3570 & 1009 & $\mathrm{MiF}$ \\
\hline Mimosa nuda var.gracilipes (Harms) Barneby & Ilha & 53 & 32,3171 & 2,1141 & 0,0052 & 0,5165 & 1,3153 & 1050 & $\mathrm{C}$ \\
\hline Mimosa nuda var.gracilipes (Harms) Barneby & Parcela & 86 & 43,2161 & 6,37037 & 0,0548 & 5,48762 & 5,929 & 1050 & $\mathrm{C}$ \\
\hline Mimosa xanthocentra Mart. & Ilha & 101 & 61,5854 & 4,0287 & 0,0308 & 3,0753 & 3,5520 & 958 & NF \\
\hline Mimosa xanthocentra Mart. & Parcela & 73 & 36,6834 & 5,40741 & 0,0535 & 5,35435 & 5,3809 & 958 & NF \\
\hline Senna pilifera (Vogel) H.S. Irwin \& Barneby & Ilha & 4 & 2,4390 & 0,1596 & 0,0003 & 0,0314 & 0,0955 & 707 & NF \\
\hline Stylosanthes acuminata M. B. Ferreira \& S. Costa & Ilha & 27 & 16,4634 & 1,0770 & 0,0042 & 0,4167 & 0,7469 & 956 & $\mathrm{C}$ \\
\hline Stylosanthes acuminata M. B. Ferreira \& S. Costa & Parcela & 31 & 15,5779 & 2,2963 & 0,0162 & 1,62263 & 1,9595 & 956 & C \\
\hline Stylosanthes capitata Vogel & Ilha & 3 & 1,8293 & 0,1197 & 0,0002 & 0,0153 & 0,0675 & 1108 & $\mathrm{NF}$ \\
\hline Zornia reticulata Sm. & Ilha & 5 & 3,0488 & 0,1994 & 0,0003 & 0,0322 & 0,1158 & 1134 & $\mathrm{C}$ \\
\hline Zornia reticulata $\mathrm{Sm}$. & Parcela & 32 & 16,0804 & 2,37037 & 0,008 & 0,79632 & 1,5833 & 1134 & C \\
\hline \multicolumn{10}{|l|}{ IRIDACEAE } \\
\hline Cipura formosa Ravenna & Ilha & 1 & 0,6098 & 0,0399 & 0,0001 & 0,0080 & 0,0239 & 865 & G \\
\hline Cipura formosa Ravenna & Parcela & 4 & 2,01005 & 0,2963 & 0,0003 & 0,02666 & 0,1615 & 865 & G \\
\hline
\end{tabular}


continuação Anexo 1

\begin{tabular}{|c|c|c|c|c|c|c|c|c|c|}
\hline $\begin{array}{l}\text { FAMÍLIA } \\
\text { Espécie }\end{array}$ & $\begin{array}{c}\text { Tipo } \\
\text { amostragem }\end{array}$ & UA & FA & FR & DoA & DoR & VI & N.coletor & $\begin{array}{c}\text { Forma } \\
\text { vida }\end{array}$ \\
\hline \multicolumn{10}{|l|}{ KRAMERIACEAE } \\
\hline \multicolumn{10}{|l|}{ LAMIACEAE } \\
\hline Hyptis brevipes Poit. & Parcela & 1 & 0,50251 & 0,07407 & 0,0001 & 0,00666 & 0,0404 & 1012 & $\mathrm{~T}$ \\
\hline Hyptis cf. pectinata (L.) Poit. & Ilha & 5 & 3,0488 & 0,1994 & 0,0005 & 0,0517 & 0,1256 & 1267 & $\mathrm{NF}$ \\
\hline \multicolumn{10}{|l|}{ LYTHRACEAE } \\
\hline Cuphea cf. micrantha Kunth & Ilha & 27 & 16,4634 & 1,0770 & 0,0019 & 0,1894 & 0,6332 & 785 & $\mathrm{~T}$ \\
\hline Cuphea cf. micrantha Kunth & Parcela & 3 & 1,50754 & 0,22222 & 0,0003 & 0,02666 & 0,1244 & 785 & $\mathrm{~T}$ \\
\hline Rotala sp. & Ilha & 1 & 0,6098 & 0,0399 & 0,0000 & 0,0000 & 0,0199 & 1391 & $\mathrm{~T}$ \\
\hline \multicolumn{10}{|l|}{ MALPIGHIACEAE } \\
\hline Aspicarpa pulchella O'Donell \& Lourteig & Ilha & 30 & 18,2927 & 1,1966 & 0,0083 & 0,8314 & 1,0140 & 769 & $\mathrm{NF}$ \\
\hline Heteropterys sp. & Ilha & 1 & 0,6098 & 0,0399 & 0,0001 & 0,0060 & 0,0230 & 1285 & $\mathrm{~L}$ \\
\hline Janusia guaranitica (A. St.-Hil.) A. Juss. & Ilha & 4 & 2,4390 & 0,1596 & 0,0000 & 0,0041 & 0,0818 & 819 & $\mathrm{~L}$ \\
\hline Janusia guaranitica (A. St.-Hil.) A. Juss. & Parcela & 1 & 0,50251 & 0,07407 & 0,0001 & 0,00333 & 0,0387 & 819 & $\mathrm{~L}$ \\
\hline \multicolumn{10}{|l|}{ MALVACEAE } \\
\hline Ayenia tomentosa $\mathrm{L}$. & Ilha & 22 & 13,4146 & 0,8775 & 0,0003 & 0,0314 & 0,4545 & 1081 & $\mathrm{C}$ \\
\hline $\begin{array}{l}\text { Ayenia tomentosa L. } \\
172\end{array}$ & Parcela & 6 & 3,01508 & 0,44444 & 0,0007 & 0,0733 & 0,2589 & 1081 & C \\
\hline
\end{tabular}


continuação Anexo 1

\begin{tabular}{|c|c|c|c|c|c|c|c|c|c|}
\hline $\begin{array}{l}\text { FAMÍLIA } \\
\text { Espécie }\end{array}$ & $\begin{array}{c}\text { Tipo } \\
\text { amostragem }\end{array}$ & UA & FA & FR & DoA & DoR & VI & N.coletor & $\begin{array}{c}\text { Forma } \\
\text { vida }\end{array}$ \\
\hline \multicolumn{10}{|l|}{ MALVACEAE } \\
\hline Corchorus hirtus L. & Ilha & 5 & 3,0488 & 0,1994 & 0,0000 & 0,0047 & 0,1021 & 946 & $\mathrm{~T}$ \\
\hline Luehea candicans Mart. & Ilha & 6 & 3,6585 & 0,2393 & 0,0062 & 0,6219 & 0,4306 & 847 & $\mathrm{MiF}$ \\
\hline Pavonia sidifolia Kunth & Ilha & 12 & 7,3171 & 0,4787 & 0,0031 & 0,3060 & 0,3924 & 928 & NF \\
\hline $\begin{array}{l}\text { Pseudobombax marginatum (A. St.-Hil., Juss. \& Cambess.) A. } \\
\text { Robyns }\end{array}$ & Ilha & 8 & 4,8780 & 0,3191 & 0,0151 & 1,5057 & 0,9124 & 1046 & $\mathrm{MiF}$ \\
\hline Sida cordifolia L. & Ilha & 1 & 0,6098 & 0,0399 & 0,0000 & 0,0007 & 0,0203 & 1279 & NF \\
\hline Sida cordifolia L. & Parcela & 1 & 0,50251 & 0,07407 & 0,0001 & 0,00333 & 0,0387 & 1279 & NF \\
\hline Sida glomerata Cav. & Ilha & 7 & 4,2683 & 0,2792 & 0,0003 & 0,0311 & 0,1552 & 1281 & NF \\
\hline Sida glomerata Cav. & Parcela & 1 & 0,50251 & 0,07407 & 0,0001 & 0,00333 & 0,0387 & 1281 & NF \\
\hline Sida linifolia Cav. & Ilha & 1 & 0,6098 & 0,0399 & 0,0001 & 0,0052 & 0,0225 & 1034 & NF \\
\hline Sterculia striata A. St.-Hil. \& Naudin & Ilha & 1 & 0,6098 & 0,0399 & 0,0052 & 0,5245 & 0,2822 & 1481 & $\mathrm{MiF}$ \\
\hline Waltheria operculata Rose & Ilha & 18 & 10,9756 & 0,7180 & 0,0006 & 0,0589 & 0,3884 & 771 & $\mathrm{C}$ \\
\hline Waltheria operculata Rose & Parcela & 68 & 34,1709 & 5,03704 & 0,01 & 1,0029 & 3,02 & 771 & $\mathrm{C}$ \\
\hline Waltheria sp1 & Ilha & 4 & 2,4390 & 0,1596 & 0,0000 & 0,0025 & 0,0810 & 942 & NF \\
\hline Waltheria sp1 & Parcela & 4 & 2,01005 & 0,2963 & 0,0004 & 0,03665 & 0,1665 & 942 & NF \\
\hline Waltheria sp2 & Ilha & 1 & 0,6098 & 0,0399 & 0,0000 & 0,0004 & 0,0201 & 1084 & NF \\
\hline Wissadula macrantha R.E.Fr. & Ilha & 1 & 0,6098 & 0,0399 & 0,0007 & 0,0681 & 0,0540 & 986 & NF \\
\hline \multicolumn{10}{|l|}{ MELIACEAE } \\
\hline Trichilia catigua A. Juss. & Ilha & 1 & 0,6098 & 0,0399 & 0,0002 & 0,0158 & 0,0278 & 1480 & $\mathrm{MiF}$ \\
\hline Trichilia elegans A. Juss. & Ilha & 1 & 0,6098 & 0,0399 & 0,0005 & 0,0520 & 0,0459 & 1478 & $\mathrm{MiF}$ \\
\hline \multicolumn{10}{|l|}{ MOLLUGINACEAE } \\
\hline Mollugo verticillata $\mathrm{L}$. & Ilha & 13 & 7,9268 & 0,5185 & 0,0002 & 0,0165 & 0,2675 & 839 & $\mathrm{~T}$ \\
\hline Mollugo verticillata $\mathrm{L}$. & Parcela & 23 & 11,5578 & 1,7037 & 0,0035 & 0,35318 & 1,0284 & 839 & $\mathrm{~T}$ \\
\hline
\end{tabular}


continuação Anexo 1

\begin{tabular}{|c|c|c|c|c|c|c|c|c|c|}
\hline $\begin{array}{l}\text { FAMÍLIA } \\
\text { Espécie }\end{array}$ & $\begin{array}{c}\text { Tipo } \\
\text { amostragem }\end{array}$ & UA & FA & FR & DoA & DoR & VI & N.coletor & $\begin{array}{c}\text { Forma } \\
\text { vida }\end{array}$ \\
\hline \multicolumn{10}{|l|}{ MYRTACEAE } \\
\hline Eugenia pyriformis Cambess. & Ilha & 10 & 6,0976 & 0,3989 & 0,0058 & 0,5764 & 0,4877 & 1127 & NF \\
\hline Myrcia laruotteana Cambess. & Ilha & 15 & 9,1463 & 0,5983 & 0,0021 & 0,2107 & 0,4045 & 1264 & $\mathrm{NF}$ \\
\hline \multicolumn{10}{|l|}{ OCHNACEAE } \\
\hline Ludwigia sp1 & Ilha & 1 & 0,6098 & 0,0399 & 0,0000 & 0,0000 & 0,0200 & 1213 & $\mathrm{~T}$ \\
\hline Ludwigia sp2 & Ilha & 1 & 0,6098 & 0,0399 & 0,0000 & 0,0036 & 0,0217 & 1216 & $\mathrm{~T}$ \\
\hline Ludwigia sp3 & Ilha & 1 & 0,6098 & 0,0399 & 0,0000 & 0,0000 & 0,0200 & 869 & $\mathrm{~T}$ \\
\hline \multicolumn{10}{|l|}{ OPHIOGLOSSACEAE } \\
\hline Ophioglossum sp. & Ilha & 1 & 0,6098 & 0,0399 & 0,0000 & 0,0009 & 0,0204 & 1262 & $\mathrm{~T}$ \\
\hline Ophioglossum sp. & Parcela & 3 & 1,50754 & 0,22222 & 0,0004 & 0,03998 & 0,1311 & 1262 & $\mathrm{~T}$ \\
\hline Oxalis sp2 & Ilha & 5 & 3,0488 & 0,1994 & 0,0001 & 0,0083 & 0,1039 & 893 & NF \\
\hline \multicolumn{10}{|l|}{ PHYLLANTHACEAE } \\
\hline Phyllanthus orbiculatus Rich. & Ilha & 27 & 16,4634 & 1,0770 & 0,0003 & 0,0288 & 0,5529 & 1266 & $\mathrm{C}$ \\
\hline \multicolumn{10}{|l|}{ PHYTOLACCACEAE } \\
\hline Microtea scabrida Urb. & Ilha & 49 & 29,8780 & 1,9545 & 0,0031 & 0,3091 & 1,1318 & 910 & NF \\
\hline $\begin{array}{c}\text { Microtea scabrida Urb. } \\
174\end{array}$ & Parcela & 15 & 7,53769 & 1,11111 & 0,0011 & 0,11328 & 0,6122 & 910 & NF \\
\hline
\end{tabular}


continuação Anexo 1

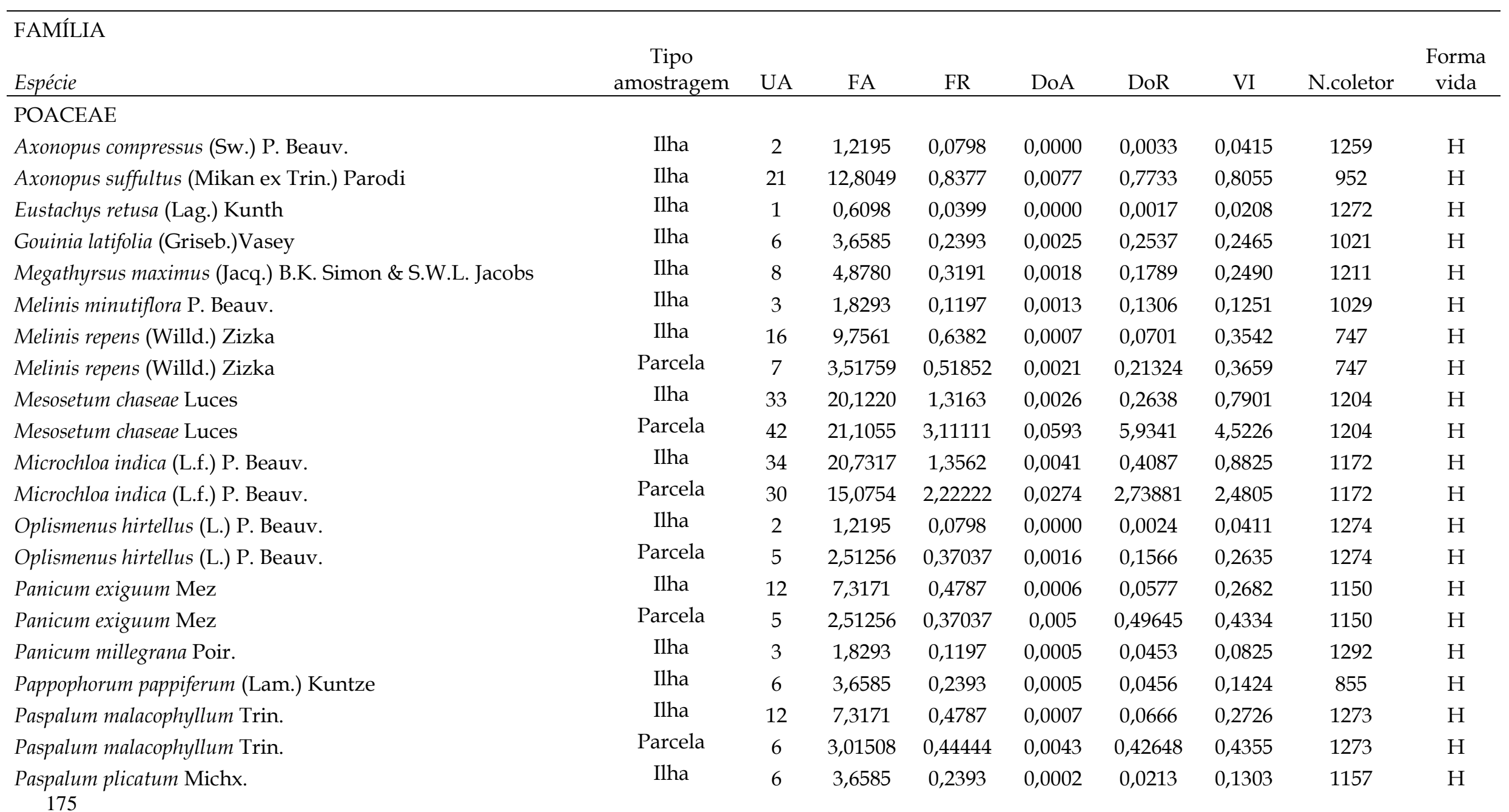


continuação Anexo 1

\begin{tabular}{|c|c|c|c|c|c|c|c|c|c|}
\hline $\begin{array}{l}\text { FAMÍLIA } \\
\text { Espécie }\end{array}$ & $\begin{array}{c}\text { Tipo } \\
\text { amostragem }\end{array}$ & UA & FA & FR & DoA & DoR & VI & N.coletor & $\begin{array}{c}\text { Forma } \\
\text { vida }\end{array}$ \\
\hline \multicolumn{10}{|l|}{ POACEAE } \\
\hline Setaria parviflora (Poir.) Kerguélen & Ilha & 2 & 1,2195 & 0,0798 & 0,0008 & 0,0818 & 0,0808 & 1294 & $\mathrm{H}$ \\
\hline Sporobulus monandrus Roseng., Arril \& Izag. & Ilha & 68 & 41,4634 & 2,7124 & 0,0188 & 1,8828 & 2,2976 & 1145 & $\mathrm{H}$ \\
\hline Sporobulus monandrus Roseng., Arril \& Izag. & Parcela & 84 & 42,2111 & 6,22222 & 0,1637 & 16,3762 & 11,299 & 1145 & $\mathrm{H}$ \\
\hline Tripogon spicatus (Nees) Ekman & Ilha & 59 & 35,9756 & 2,3534 & 0,0027 & 0,2722 & 1,3128 & 1131 & $\mathrm{H}$ \\
\hline Tripogon spicatus (Nees) Ekman & Parcela & 81 & 40,7035 & 6 & 0,0685 & 6,85703 & 6,4285 & 1131 & $\mathrm{H}$ \\
\hline Urochloa adspersa (Trin.) RD.Webester & Ilha & 13 & 7,9268 & 0,5185 & 0,0061 & 0,6075 & 0,5630 & 1187 & $\mathrm{H}$ \\
\hline Urochloa adspersa (Trin.) RD.Webester & Parcela & 2 & 1,00503 & 0,14815 & 0,0024 & 0,23656 & 0,1924 & 1277 & $\mathrm{H}$ \\
\hline \multicolumn{10}{|l|}{ POLYGALACEAE } \\
\hline Bredemeyra floribunda Willd. & Ilha & 5 & 3,0488 & 0,1994 & 0,0012 & 0,1177 & 0,1586 & 1037 & $\mathrm{MiF}$ \\
\hline \multicolumn{10}{|l|}{ POLYPODIACEAE } \\
\hline Microgramma vacciniifolia (Langsd. \& Fisch.) Copel. & Ilha & 1 & 0,6098 & 0,0399 & 0,0000 & 0,0047 & 0,0223 & 1487 & $\mathrm{E}$ \\
\hline \multicolumn{10}{|l|}{ PORTULACACEAE } \\
\hline Portulaca mucronata Link & Ilha & 7 & 4,2683 & 0,2792 & 0,0001 & 0,0133 & 0,1463 & 882 & $\mathrm{C}$ \\
\hline Portulaca mucronata Link & Parcela & 1 & 0,50251 & 0,07407 & 0,0001 & 0,00666 & 0,0404 & 882 & $\mathrm{C}$ \\
\hline Portulaca sp1 & Ilha & 47 & 28,6585 & 1,8748 & 0,0022 & 0,2152 & 1,0450 & 970 & C \\
\hline Portulaca sp1 & Parcela & 45 & 22,6131 & 3,33333 & 0,0055 & 0,54976 & 1,9415 & 970 & $\mathrm{C}$ \\
\hline Portulaca sp2 & Parcela & 2 & 1,00503 & 0,14815 & 0,0002 & 0,01999 & 0,0841 & 1340 & C \\
\hline Portulaca sp3 & Parcela & 8 & 4,0201 & 0,59259 & 0,0006 & 0,05997 & 0,3263 & 901 & $\mathrm{C}$ \\
\hline Portulaca sp4 & Ilha & 1 & 0,6098 & 0,0399 & 0,0001 & 0,0080 & 0,0239 & 1367 & $\mathrm{C}$ \\
\hline Portulaca sp4 & Parcela & 1 & 0,50251 & 0,07407 & 0,0001 & 0,00333 & 0,0387 & 1367 & $\mathrm{C}$ \\
\hline
\end{tabular}


continuação Anexo 1

\begin{tabular}{|c|c|c|c|c|c|c|c|c|c|}
\hline $\begin{array}{l}\text { FAMÍLIA } \\
\text { Espécie }\end{array}$ & $\begin{array}{c}\text { Tipo } \\
\text { amostragem }\end{array}$ & UA & FA & FR & DoA & DoR & VI & N.coletor & $\begin{array}{c}\text { Forma } \\
\text { vida }\end{array}$ \\
\hline \multicolumn{10}{|l|}{ PTERIDACEAE } \\
\hline Doryopteris concolor (Langsd. \& Fisch.) Kuhn & Ilha & 2 & 1,2195 & 0,0798 & 0,0001 & 0,0079 & 0,0438 & 889 & $\mathrm{H}$ \\
\hline \multicolumn{10}{|l|}{ RHAMNACEAE } \\
\hline Gouania cf. lupuloides (L.) Urb. & Ilha & 6 & 3,6585 & 0,2393 & 0,0038 & 0,3849 & 0,3121 & 881 & $\mathrm{~L}$ \\
\hline Borreria verticillata (L.)G.Mey. & Ilha & 38 & 23,1707 & 1,5158 & 0,0017 & 0,1717 & 0,8437 & 1138 & $\mathrm{C}$ \\
\hline Borreria verticillata (L.)G.Mey. & Parcela & 3 & 1,50754 & 0,22222 & 0,0001 & 0,01333 & 0,1178 & 1138 & $\mathrm{C}$ \\
\hline Coutarea sp. & Ilha & 1 & 0,6098 & 0,0399 & 0,0004 & 0,0363 & 0,0381 & 906 & NF \\
\hline Psychotria sp. & Ilha & 6 & 3,6585 & 0,2393 & 0,0018 & 0,1828 & 0,2111 & 1441 & NF \\
\hline Staelia sp. & Ilha & 89 & 54,2683 & 3,5501 & 0,0201 & 2,0110 & 2,7805 & 874 & C \\
\hline Staelia sp. & Parcela & 69 & 34,6734 & 5,11111 & 0,0325 & 3,25526 & 4,1832 & 874 & $\mathrm{C}$ \\
\hline \multicolumn{10}{|l|}{ SALICACEAE } \\
\hline Casearia gossypiosperma Briq. & Ilha & 7 & 4,2683 & 0,2792 & 0,0027 & 0,2704 & 0,2748 & 1086 & $\mathrm{MiF}$ \\
\hline Casearia sylvestris $\mathrm{Sw}$. & Ilha & 6 & 3,6585 & 0,2393 & 0,0013 & 0,1347 & 0,1870 & 1057 & $\mathrm{MiF}$ \\
\hline \multicolumn{10}{|l|}{ SAPINDACEAE } \\
\hline Dilodendron bipinnatum Radlk. & Ilha & 1 & 0,6098 & 0,0399 & 0,0013 & 0,1264 & 0,0831 & 1485 & $\mathrm{MiF}$ \\
\hline Serjania sp1 & Ilha & 2 & 1,2195 & 0,0798 & 0,0008 & 0,0831 & 0,0815 & 1027 & $\mathrm{~L}$ \\
\hline
\end{tabular}


continuação Anexo 1

\begin{tabular}{|c|c|c|c|c|c|c|c|c|c|}
\hline $\begin{array}{l}\text { FAMÍLIA } \\
\text { Espécie }\end{array}$ & $\begin{array}{c}\text { Tipo } \\
\text { amostragem }\end{array}$ & UA & FA & FR & DoA & DoR & VI & N.coletor & $\begin{array}{c}\text { Forma } \\
\text { vida }\end{array}$ \\
\hline \multicolumn{10}{|l|}{ SAPINDACEAE } \\
\hline Serjania sp2 & Ilha & 3 & 1,8293 & 0,1197 & 0,0005 & 0,0523 & 0,0860 & 1188 & $\mathrm{~L}$ \\
\hline Serjania sp3 & Ilha & 1 & 0,6098 & 0,0399 & 0,0009 & 0,0874 & 0,0636 & 1464 & $\mathrm{~L}$ \\
\hline Talisia esculenta (A.St.-Hil.) Radlk. & Ilha & 3 & 1,8293 & 0,1197 & 0,0021 & 0,2081 & 0,1639 & 1482 & $\mathrm{MiF}$ \\
\hline \multicolumn{10}{|l|}{ SAPOTACEAE } \\
\hline Pouteria sp1 & Ilha & 14 & 8,5366 & 0,5584 & 0,0065 & 0,6458 & 0,6021 & 1059 & NF \\
\hline Pouteria sp2 & Ilha & 2 & 1,2195 & 0,0798 & 0,0018 & 0,1752 & 0,1275 & 1166 & NF \\
\hline \multicolumn{10}{|l|}{ SCHIZAEACEAE } \\
\hline Anemia tomentosa (Savigny) Sw. & Ilha & 76 & 46,3415 & 3,0315 & 0,0185 & 1,8457 & 2,4386 & 858 & $\mathrm{H}$ \\
\hline Anemia tomentosa (Savigny) Sw. & Parcela & 10 & 5,02513 & 0,74074 & 0,0051 & 0,51311 & 0,6269 & 858 & $\mathrm{H}$ \\
\hline \multicolumn{10}{|l|}{ SELAGINELLACEAE } \\
\hline Selaginella convoluta (Arn.) Spring & Ilha & 36 & 21,9512 & 1,4360 & 0,0032 & 0,3204 & 0,8782 & 1479 & $\mathrm{H}$ \\
\hline Selaginella convoluta (Arn.) Spring & Parcela & 15 & 7,53769 & 1,11111 & 0,002 & 0,19991 & 0,6555 & 1479 & $\mathrm{H}$ \\
\hline Selaginella marginata (Humb. \& Bonpl. ex Willd.) Spring & Ilha & 8 & 4,8780 & 0,3191 & 0,0015 & 0,1510 & 0,2350 & 750 & $\mathrm{C}$ \\
\hline Selaginella marginata (Humb. \& Bonpl. ex Willd.) Spring & Parcela & 2 & 1,00503 & 0,14815 & 0,0007 & 0,06664 & 0,1074 & 750 & $\mathrm{C}$ \\
\hline Selaginella sellowii Hieron. & Ilha & 120 & 73,1707 & 4,7866 & 0,0281 & 2,8100 & 3,7983 & 1311 & $\mathrm{H}$ \\
\hline Selaginella sellowii Hieron. & Parcela & 157 & 78,8945 & 11,6296 & 0,329 & 32,9211 & 22,275 & 1311 & $\mathrm{H}$ \\
\hline \multicolumn{10}{|l|}{ SMILACACEAE } \\
\hline Smilax cf. fluminensis Steud. & Ilha & 4 & 2,4390 & 0,1596 & 0,0004 & 0,0375 & 0,0985 & 1045 & $\mathrm{~L}$ \\
\hline \multicolumn{10}{|l|}{ TURNERACEAE } \\
\hline Piriqueta cf. corumbensis Moura & Ilha & 2 & 1,2195 & 0,0798 & 0,0000 & 0,0022 & 0,0410 & 1052 & $\mathrm{C}$ \\
\hline Turnera grandilfora (Urb.) Arbo & Ilha & 10 & 6,0976 & 0,3989 & 0,0006 & 0,0649 & 0,2319 & 1141 & $\mathrm{C}$ \\
\hline Turnera cf. pumilea L. & Parcela & 10 & 5,02513 & 0,74074 & 0,0007 & 0,06664 & 0,4037 & 820 & $\mathrm{C}$ \\
\hline
\end{tabular}


continuação Anexo 1

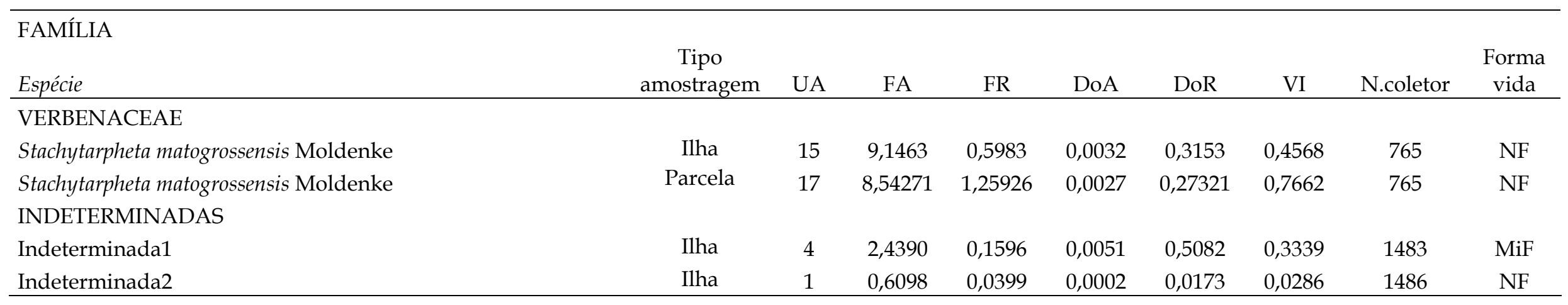


Anexo 2 - Lista de famílias e espécies vasculares amostradas em parcelas de $1 \times 1$ m e em ilhas de solo por localidade, Corumbá, MS e abreviaturas utilizadas nas análises de ordenação. BA=Fazenda Banda Alta, CA=Fazenda São Sebastião do Carandá, $\mathrm{MO}=$ Fazenda Monjolinho.

\begin{tabular}{|c|c|c|c|c|c|c|c|}
\hline \multirow{2}{*}{$\begin{array}{l}\text { Família } \\
\text { Espécie }\end{array}$} & \multirow[b]{2}{*}{ Abr. } & \multicolumn{3}{|c|}{ Parcela } & \multicolumn{3}{|l|}{ Ilha } \\
\hline & & BA & CA & $\mathrm{MO}$ & BA & CA & $\mathrm{MO}$ \\
\hline \multicolumn{8}{|l|}{ Acanthaceae } \\
\hline Anisacanthus boliviensis (Nees)Wassh. & & & & & $x$ & & \\
\hline Ruellia ciliatiflora Hook. & & & & & & $\mathrm{x}$ & \\
\hline \multicolumn{8}{|l|}{ Amaranthaceae } \\
\hline Gomphrena centrota E. Holzh. & $\mathrm{GOM}$ & $\mathrm{x}$ & & & $x$ & & \\
\hline Gomphrena vaga Mart. & GOV & & & & $x$ & $x$ & $x$ \\
\hline Gomphrena sp. & & & & & $x$ & & \\
\hline \multicolumn{8}{|l|}{ Amaryllidaceae } \\
\hline Zephyranthes cearensis (Herb.)Baker & ZEP & $x$ & & & & & \\
\hline \multicolumn{8}{|l|}{ Anacardiaceae } \\
\hline Astronium fraxinifolium Schott & FRA & & & & $x$ & $x$ & $x$ \\
\hline Myracrodruon urundeuva Allemão & MYR & & & & $\mathrm{x}$ & $\mathrm{x}$ & $x$ \\
\hline \multicolumn{8}{|l|}{ Annonaceae } \\
\hline Annona nutans (R.E. Fr.) R.E. Fr. & ANN & & & & & & $x$ \\
\hline \multicolumn{8}{|l|}{ Apocynaceae } \\
\hline Aspidosperma pyrifolium Mart. & PYR & & & & $x$ & $x$ & \\
\hline Aspidosperma quirandy Hassl. & & & & & & & $x$ \\
\hline Blepharodon nitidum (Vell.) J.F. Macbr. & BLE & & & & & & $x$ \\
\hline Forsteronia thyrsoidea (Vell.) Müll. Arg. & FOR & & & & $x$ & $x$ & $x$ \\
\hline Mandevilla sp. & MAN & & & & & & $x$ \\
\hline Prestonia tomentosa R.Br. & & & & & & $x$ & \\
\hline Apocynaceae indeterminada1 & & & & & & $\mathrm{x}$ & \\
\hline \multicolumn{8}{|l|}{ Araceae } \\
\hline Philodendron sp. & $\mathrm{IMB}$ & & & & & & $x$ \\
\hline \multicolumn{8}{|l|}{ Arecaceae } \\
\hline Acrocomia aculeata (Jacq.) Lodd. ex Mart. & $\mathrm{ACR}$ & & & & $x$ & & $x$ \\
\hline \multicolumn{8}{|l|}{ Aristolochiaceae } \\
\hline Aristolochia cf. esperanzae Kuntze & ARI & & & & $x$ & & $x$ \\
\hline \multicolumn{8}{|l|}{ Asteraceae } \\
\hline Calea elongata Baker & CAL & $x$ & $x$ & & $x$ & $\mathrm{x}$ & $x$ \\
\hline Conyza bonariensis (L.) Cronquist & & & & & $x$ & & \\
\hline
\end{tabular}


continuação Anexo 2

\begin{tabular}{|c|c|c|c|c|c|c|c|}
\hline \multirow[b]{2}{*}{ Espécie } & \multirow[b]{2}{*}{ Abr. } & \multicolumn{3}{|c|}{ Parcela } & \multicolumn{2}{|l|}{ Ilha } & \multirow[b]{2}{*}{$\mathrm{MO}$} \\
\hline & & $\mathrm{BA}$ & CA & $\mathrm{MO}$ & $\mathrm{BA}$ & CA & \\
\hline \multicolumn{8}{|l|}{ Asteraceae } \\
\hline Lepidaploa salzmanii (DC)H.Rob. & LEP & $\mathrm{x}$ & $x$ & $x$ & $x$ & $x$ & $x$ \\
\hline \multicolumn{8}{|l|}{ Bignoniaceae } \\
\hline Cuspidaria sp. & & & & & $x$ & $x$ & $x$ \\
\hline Jacaranda cuspidifolia Mart. & JAC & & & & & $x$ & $x$ \\
\hline Melloa sp. & & & & & $x$ & & \\
\hline Tabebuia impetiginosa (Mart. ex DC.) Standl. & $\mathrm{TAB}$ & & & & $x$ & $x$ & \\
\hline Bignoniaceae & & & & & $x$ & $x$ & \\
\hline \multicolumn{8}{|l|}{ Bixaceae } \\
\hline Cochlospermum regium (Schrank) Pilg. & $\mathrm{COC}$ & $x$ & & & & & $x$ \\
\hline \multicolumn{8}{|l|}{ Brassicaceae } \\
\hline Cleome eosina J.F. Macbr. & CLE & $\mathrm{x}$ & & & $x$ & & \\
\hline Cleome guianensis Aubl. & CLG & $x$ & & $x$ & $x$ & $x$ & $x$ \\
\hline \multicolumn{8}{|l|}{ Bromeliaceae } \\
\hline Bromelia balansae Mez & BRO & & & & $x$ & $x$ & $x$ \\
\hline Deuterocohnia meziana Kuntze ex Mez & DEU & & & & $x$ & & $x$ \\
\hline Dyckia sp1 & & & & & $x$ & $x$ & $x$ \\
\hline Dyckia sp2 & DY2 & & & & $x$ & $x$ & $x$ \\
\hline Tillandsia loliacea Mart. ex Schult \& Schult f. & & & & & & & $x$ \\
\hline \multicolumn{8}{|l|}{ Burseraceae } \\
\hline Commiphora leptophloeos (Mart.) J.B. Gillett & BUR & & & & $x$ & $x$ & $x$ \\
\hline \multicolumn{8}{|l|}{ Cactaceae } \\
\hline Cereus bicolor Rizzini \& Mattos & $\mathrm{BIC}$ & & & & $x$ & $x$ & $x$ \\
\hline Discocactus ferricola Buining \& Brederoo & DIS & $x$ & $x$ & $x$ & $x$ & $x$ & $x$ \\
\hline Frailea cataphracta (Dams) Britton \& Rose & & & & & $x$ & & \\
\hline Harrisia balansae (K. Schum.) N.P. Taylor \& Zappi & HAR & & & & $x$ & $x$ & $x$ \\
\hline Opuntia sp. & & & & & $x$ & & \\
\hline Praecereus euchlorus (F.A.C. Weber) N.P. Taylor & PRA & & & & $x$ & $x$ & $x$ \\
\hline \multicolumn{8}{|l|}{ Cannabaceae } \\
\hline Celtis pubescens Spreng. & CEL & & & & $x$ & & $x$ \\
\hline \multicolumn{8}{|l|}{ Caryophyllaceae } \\
\hline Polycarpaea corymbosa (L.) Lam. & PCO & $x$ & & $\mathrm{x}$ & $\mathrm{x}$ & & $x$ \\
\hline \multicolumn{8}{|l|}{ Combretaceae } \\
\hline Combretum duarteanum Cambess. & $\mathrm{CDU}$ & & & & $x$ & $x$ & $x$ \\
\hline Combretum leprosum Mart. & & & & & $x$ & & \\
\hline Terminalia argentea Mart. & & & & & & & $x$ \\
\hline
\end{tabular}


continuação Anexo 2

\begin{tabular}{|c|c|c|c|c|c|c|c|}
\hline \multirow[b]{2}{*}{ Espécie } & \multirow[b]{2}{*}{ Abr. } & \multicolumn{3}{|c|}{ Parcela } & \multicolumn{3}{|l|}{ Ilha } \\
\hline & & $\mathrm{BA}$ & CA & $\mathrm{MO}$ & BA & $\mathrm{CA}$ & $\mathrm{MO}$ \\
\hline \multicolumn{8}{|l|}{ Commelinaceae } \\
\hline Commelina sp. & COMM & & & & $x$ & $\mathrm{x}$ & $\mathrm{x}$ \\
\hline Tripogandra glandulosa (Seub.) Rohweder & & & & & $\mathrm{x}$ & & \\
\hline \multicolumn{8}{|l|}{ Convolvulaceae } \\
\hline Evolvulus alopecuroides Mart. & EVA & $x$ & $x$ & & $x$ & $x$ & \\
\hline Evolvulus filipes Mart. & EVF & & & $x$ & & & $\mathrm{x}$ \\
\hline Jacquemontia evolvuloides (Moric.) Meissn. & JAE & $x$ & $x$ & & $x$ & $x$ & \\
\hline Jacquemontia fruticulosa Hallier f. & JAF & & & $\mathrm{x}$ & & & $\mathrm{x}$ \\
\hline \multicolumn{8}{|l|}{ Cucurbitaceae } \\
\hline Cayaponia sp. & & & & & $x$ & $x$ & $\mathrm{x}$ \\
\hline \multicolumn{8}{|l|}{ Cyperaceae } \\
\hline Cyperus aggregatus (Willd.) Endl. & CYA & $x$ & & $x$ & $x$ & $x$ & $\mathrm{x}$ \\
\hline Cyperus cornelii-ostenii Kük. & $\mathrm{CYC}$ & $x$ & & $x$ & $x$ & & $\mathrm{x}$ \\
\hline Cyperus laxus Lam. & CYL & & & & & & $x$ \\
\hline Cyperus subcastaneus D.A. Simpson & CYS & & & & & $x$ & \\
\hline Cyperus surinamensis Rottb. & & & & & $x$ & & \\
\hline Cyperus uncinulatus Poir. & $\mathrm{CYU}$ & $x$ & & $x$ & $x$ & $x$ & $x$ \\
\hline Fimbristylis sp. & FIM & $x$ & $x$ & & & & \\
\hline Kyllinga odorata Vahl & KYL & $x$ & & & $x$ & & $x$ \\
\hline \multicolumn{8}{|l|}{ Erythroxylaceae } \\
\hline Erythroxylum deciduum A. St.-Hil. & ERY & & & & $x$ & $x$ & $x$ \\
\hline Erythroxylum sp. & ERY2 & & & & & $x$ & $\mathrm{x}$ \\
\hline \multicolumn{8}{|l|}{ Euphorbiaceae } \\
\hline Acalypha communis Müll. Arg. & & & & & & & $x$ \\
\hline Actinostemon communis (Müll. Arg.) Pax & & & & & & $x$ & \\
\hline Cnidioscolus urens L. & & & & & $x$ & & $x$ \\
\hline Croton glandulosus L. & & & & & $x$ & & \\
\hline Croton pedicellatus Kunth & CRP & & $x$ & $x$ & & $x$ & $\mathrm{x}$ \\
\hline Dalechampia brasiliensis Lam. & & & & & $x$ & & \\
\hline Jatropha ribifolia (Pohl) Baill. & JAT & & & & $x$ & $x$ & \\
\hline Jatropha weddelliana Baill. & & & & & $x$ & & \\
\hline Manihot anomala Pohl & & & & & & $x$ & \\
\hline \multicolumn{8}{|l|}{ Fabaceae } \\
\hline Aeschnomene histrix Poir. & AES & $x$ & $x$ & $x$ & $x$ & $x$ & $\mathrm{x}$ \\
\hline Alysicarpus vaginalis (L.) DC. & ALY & $x$ & & & $x$ & & \\
\hline Amburana cearensis (Allemão) A.C. Sm. & $\mathrm{AMB}$ & & & & $x$ & $x$ & \\
\hline Anadenanthera colubrina (Vell.) Brenan & ANA & & & & $x$ & $x$ & $x$ \\
\hline Bauhinia pentandra (Bong.) Vogel ex Steud. & BAU & & & $x$ & $x$ & $x$ & $\begin{array}{c}x \\
18\end{array}$ \\
\hline
\end{tabular}


continuação Anexo 2

\begin{tabular}{|c|c|c|c|c|c|c|c|}
\hline \multirow[b]{2}{*}{ Espécie } & \multirow[b]{2}{*}{ Abr. } & \multicolumn{3}{|c|}{ Parcela } & \multicolumn{2}{|c|}{ Ilha } & \multirow[b]{2}{*}{$\mathrm{MO}$} \\
\hline & & BA & CA & $\mathrm{MO}$ & BA & CA & \\
\hline \multicolumn{8}{|l|}{ Fabaceae } \\
\hline Camptosema ellipticum (Desv.) Burkart & CAMP & & $x$ & & $x$ & $x$ & $x$ \\
\hline Camptosema sp. & & & & & $x$ & & $\mathrm{x}$ \\
\hline Centrosema pascuorum Mart. ex Benth. & & $x$ & & & $x$ & & \\
\hline Chamaecrista flexuosa (L.) Greene & $\mathrm{CHF}$ & & $x$ & & & $\mathrm{x}$ & \\
\hline Chamaecrista serpens (L.)Greene & CHS & $x$ & & $x$ & & & \\
\hline $\begin{array}{l}\text { Guibourtia hymenaefolia (Moric.) J. Léonard } \\
\text { Lonchocarpus variabilis R.R.Silva \& } \\
\text { A.M.G.Azevedo }\end{array}$ & GUI & & & $\mathrm{x}$ & & $\mathrm{x}$ & $x$ \\
\hline Macroptilium lathyroides (L.) Urb. & & & & & & $x$ & $x$ \\
\hline Mimosa bimucronata (DC.) Kuntze var.bimucronata & MBI & & & & $x$ & $x$ & \\
\hline Mimosa nuda var.gracilipes (Harms) Barneby & MNU & $x$ & $x$ & $x$ & $x$ & $\mathrm{x}$ & $\mathrm{x}$ \\
\hline Mimosa xanthocentra Mart. & MXA & $x$ & $x$ & $x$ & $x$ & $x$ & $x$ \\
\hline Senna pilifera (Vogel) H.S. Irwin \& Barneby & SEM & & & & $x$ & & $x$ \\
\hline Stylosanthes acuminata M. B. Ferreira \& S. Costa & STY & & $x$ & $x$ & & $x$ & $x$ \\
\hline Stylosanthes capitata Vogel & STYC & & & & & $\mathrm{x}$ & \\
\hline Zornia reticulata Sm. & ZOR & & $x$ & $x$ & & $\mathrm{x}$ & $x$ \\
\hline \multicolumn{8}{|l|}{ Iridaceae } \\
\hline Cipura formosa Ravenna & CIP & $x$ & & & $x$ & & \\
\hline \multicolumn{8}{|l|}{ Krameriaceae } \\
\hline Krameria tomentosa A.St.-Hil. & & & & & $x$ & & \\
\hline \multicolumn{8}{|l|}{ Lamiaceae } \\
\hline Hyptis brevipes Poit. & & $x$ & & & & & \\
\hline Hyptis cf. pectinata (L.) Poit. & HYP2 & & & & $x$ & & $x$ \\
\hline \multicolumn{8}{|l|}{ Loganiaceae } \\
\hline Strychnos sp. & & & & & & $x$ & \\
\hline \multicolumn{8}{|l|}{ Lythraceae } \\
\hline Cuphea cf. micrantha Kunth & CUP & $x$ & & $x$ & $x$ & & $x$ \\
\hline Rotala sp. & & & & & $x$ & & \\
\hline \multicolumn{8}{|l|}{ Malpighiaceae } \\
\hline Aspicarpa pulchella O’Donell \& Lourteig & ASP & & $x$ & & $x$ & $x$ & \\
\hline Diplopterys sp. & & & & & $x$ & $x$ & \\
\hline Heteropterys cf. amplexicaulis Morong & & & & & $x$ & & \\
\hline Heteropterys sp. & & & & & $x$ & & \\
\hline Janusia guaranitica (A. St.-Hil.) A. Juss. & JAN & & & $x$ & & & $\mathrm{x}$ \\
\hline \multicolumn{8}{|l|}{ Malvaceae } \\
\hline Ayenia tomentosa L. & AYE & $x$ & & $x$ & $x$ & $x$ & $x$ \\
\hline Corchorus hirtus L. & & & & & $x$ & & $x$ \\
\hline
\end{tabular}


continuação Anexo 2

\begin{tabular}{|c|c|c|c|c|c|c|c|}
\hline \multirow[b]{2}{*}{ Espécie } & \multirow[b]{2}{*}{ Abr. } & \multicolumn{3}{|c|}{ Parcela } & \multicolumn{3}{|l|}{ Ilha } \\
\hline & & $\mathrm{BA}$ & CA & $\mathrm{MO}$ & $\mathrm{BA}$ & CA & $\mathrm{MO}$ \\
\hline \multicolumn{8}{|l|}{ Malvaceae } \\
\hline Luehea candicans Mart. & LUE & & & & $x$ & $x$ & \\
\hline Pavonia sidifolia Kunth & PAV & & & & $x$ & $x$ & $x$ \\
\hline \multicolumn{8}{|c|}{ Pseudobombax marginatum (A. St.-Hil., Juss. \& } \\
\hline Sida cordifolia $\mathrm{L}$. & SIDC & & & $\mathrm{x}$ & & & $\mathrm{x}$ \\
\hline Sida glomerata Cav. & & & & $x$ & $x$ & $x$ & $x$ \\
\hline Sida linifolia Cav. & & & & & & & $\mathrm{x}$ \\
\hline Sterculia striata A. St.-Hil. \& Naudin & & & & & & $x$ & \\
\hline Waltheria operculata Rose & WAL & $x$ & $x$ & $\mathrm{x}$ & $\mathrm{x}$ & $x$ & $x$ \\
\hline Waltheria sp1 & WAT & & & $x$ & & & $x$ \\
\hline Waltheria sp2 & WA3 & & & & & & $x$ \\
\hline Wissadula macrantha R.E.Fr. & & & & & $\mathrm{x}$ & & \\
\hline \multicolumn{8}{|l|}{ Meliaceae } \\
\hline Trichilia catigua A. Juss. & & & & & & & $x$ \\
\hline Trichilia elegans A. Juss. & & & & & & & $x$ \\
\hline \multicolumn{8}{|l|}{ Molluginaceae } \\
\hline Mollugo verticillata $\mathrm{L}$. & MOL & $x$ & & $x$ & $x$ & & $x$ \\
\hline \multicolumn{8}{|l|}{ Myrtaceae } \\
\hline Eugenia aurata $\mathrm{O}$. Berg & EUG & & & & & $x$ & \\
\hline Eugenia pyriformis Cambess. & & & & & $x$ & $\mathrm{x}$ & $x$ \\
\hline Myrcia laruotteana Cambess. & LAU & & & & & $x$ & $x$ \\
\hline \multicolumn{8}{|l|}{ Ochnaceae } \\
\hline Ouratea aff. castaneifolia (DC.) Engl. & OUR & & & & & $\mathrm{x}$ & $x$ \\
\hline \multicolumn{8}{|l|}{ Onagraceae } \\
\hline Ludwigia sp1 & & & & & $x$ & & \\
\hline Ludwigia sp2 & & & & & $\mathrm{x}$ & & \\
\hline Ludwigia sp3 & & & & & $x$ & & \\
\hline \multicolumn{8}{|l|}{ Ophioglossaceae } \\
\hline Ophioglossum sp. & $\mathrm{OPH}$ & & & $x$ & & & $x$ \\
\hline \multicolumn{8}{|l|}{ Oxalidaceae } \\
\hline Oxalis sp1 & OX1 & $x$ & & & $x$ & $x$ & \\
\hline Oxalis sp2 & OX2 & & & & & & $x$ \\
\hline \multicolumn{8}{|l|}{ Phyllanthaceae } \\
\hline Phyllanthus orbiculatus Rich. & ORB & & & & $x$ & & $x$ \\
\hline \multicolumn{8}{|l|}{ Phytolacaceae } \\
\hline Microtea scabrida Urb. & MSC & $\mathrm{x}$ & $\mathrm{x}$ & $\mathrm{x}$ & $\mathrm{x}$ & $x$ & $\mathrm{x}$ \\
\hline
\end{tabular}


continuação Anexo 2

\begin{tabular}{|c|c|c|c|c|c|c|c|}
\hline \multirow[b]{2}{*}{ Espécie } & \multirow[b]{2}{*}{ Abr. } & \multicolumn{3}{|c|}{ Parcela } & \multicolumn{3}{|l|}{ Ilha } \\
\hline & & BA & CA & $\mathrm{MO}$ & BA & $\mathrm{CA}$ & $\mathrm{MO}$ \\
\hline \multicolumn{8}{|l|}{ Poaceae } \\
\hline Axonopus compressus (Sw.) P. Beauv. & $\mathrm{AXO}$ & & & & & & $x$ \\
\hline Axonopus suffultus (Mikan ex Trin.) Parodi & & & & & $x$ & $x$ & $x$ \\
\hline Eustachys retusa (Lag.) Kunth & & & & & & & $x$ \\
\hline Gouinia latifolia (Griseb.)Vasey & LAT & & & & & $x$ & $x$ \\
\hline $\begin{array}{l}\text { Megathyrsus maximus (Jacq.) B.K. Simon \& S.W.L. } \\
\text { Jacobs }\end{array}$ & & & & & $x$ & $x$ & \\
\hline Melinis minutiflora P. Beauv. & & & & & $x$ & $x$ & \\
\hline Melinis repens (Willd.) Zizka & MEL & $x$ & & & $x$ & & $x$ \\
\hline Mesosetum chaseae Luces & $\begin{array}{l}\text { MES } \\
\text { MIND }\end{array}$ & & $x$ & $x$ & & $x$ & $x$ \\
\hline Microchloa indica (L.f.) P. Beauv. & MIC & $x$ & & $x$ & $x$ & & $x$ \\
\hline Oplismenus hirtellus (L.) P. Beauv. & OPL & & & $x$ & $x$ & & $x$ \\
\hline Panicum exiguum Mez & PAE & $x$ & $x$ & $x$ & $x$ & & $x$ \\
\hline Panicum millegrana Poir. & MIL & & & & & $x$ & \\
\hline Pappophorum pappiferum (Lam.) Kuntze & PAP & & & & $x$ & & $x$ \\
\hline Paspalum malacophyllum Trin. & PMA & & $x$ & & & $x$ & $x$ \\
\hline Paspalum plicatum Michx. & & & & & $x$ & & $x$ \\
\hline Setaria parviflora (Poir.) Kerguélen & & & & & $x$ & & $x$ \\
\hline Sporobulus monandrus Roseng., Arril \& Izag. & $\mathrm{SPO}$ & $x$ & $x$ & $x$ & $x$ & $x$ & $x$ \\
\hline Tripogon spicatus (Nees) Ekman & TRI & $x$ & $x$ & $x$ & $x$ & $x$ & $x$ \\
\hline Urochloa adspersa (Trin.) RD.Webester & URO & & & $x$ & $x$ & $x$ & $x$ \\
\hline \multicolumn{8}{|l|}{ Polygalaceae } \\
\hline Bredemeyra floribunda Willd. & BRE & & & & & $x$ & $x$ \\
\hline \multicolumn{8}{|l|}{ Polypodiaceae } \\
\hline Microgramma vacciniifolia (Langsd. \& Fisch.) Copel. & & & & & & $x$ & \\
\hline \multicolumn{8}{|l|}{ Portulacaceae } \\
\hline Portulaca mucronata Link & & $x$ & & & $x$ & & $x$ \\
\hline Portulaca sp1 & PO1 & $\mathrm{x}$ & $x$ & $x$ & $x$ & $x$ & $x$ \\
\hline Portulaca sp2 & & $x$ & & & & & \\
\hline Portulaca sp3 & PO5 & $x$ & & & & & \\
\hline Portulaca sp4 & PO3 & $x$ & & & $x$ & & \\
\hline \multicolumn{8}{|l|}{ Pteridaceae } \\
\hline Cheilanthes tweediana Hook. & CHE & & & & $x$ & $x$ & \\
\hline Doryopteris concolor (Langsd. \& Fisch.) Kuhn & & & & & $x$ & & \\
\hline \multicolumn{8}{|l|}{ Rhamnaceae } \\
\hline Gouania cf. lupuloides (L.) Urb. & RHA & & & & & $x$ & \\
\hline
\end{tabular}


continuação Anexo 2

Parcela Ilha

Espécie

Abr. BA CA $\mathrm{MO}$ BA $\mathrm{CA}$ MO

Rubiaceae

Alibertia concolor (Cham.) k.Schum.

Borreria verticillata (L.)G.Mey.

BOR

Coutarea sp.

Psychotria sp.

PSY

Staelia sp.

Tocoyena formosa (Cham. \& Schltdl.) K. Schum.

PSY

STA

TOC

Rutaceae

Helietta puberula R.E. Fr.

Zanthoxylum chiloperone Mart. ex Engl.

Salicaceae

Casearia gossypiosperma Briq.

CAS2

$x \quad x$

Casearia sylvestris Sw.

CAS

Sapindaceae

Dilodendron bipinnatum Radlk.

Serjania sp1

Serjania sp2

SER

$\mathrm{X}$

Serjania sp3

Talisia esculenta (A.St.-Hil.) Radlk.

TAL

Sapotaceae

Pouteria sp1

POU

Pouteria sp2

Schizaeaceae

Anemia tomentosa (Savigny) Sw.

ANE

$\mathrm{x}$

$x$

Selaginellaceae

Selaginella convoluta (Arn.) Spring

SEC

Selaginella marginata (Humb. \& Bonpl. ex Willd.)

Spring

SEL

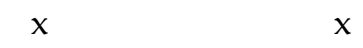

Selaginella sellowii Hieron.

Smilacaceae

Smilax cf. fluminensis Steud.

SMI

Turneraceae

Piriqueta cf. corumbensis Moura

Turnera cf. pumilea L.

TU2

$x$

Turnera grandilfora (Urb.) Arbo

TU1

x $\quad x$


continuação Anexo 2

\begin{tabular}{llllllll}
\hline & \multicolumn{3}{c}{ Parcela } & & Ilha & & \\
Espécie & Abr. & BA & CA & MO & BA & CA & MO \\
\hline Verbenaceae & & & & & & & \\
Stachytarpheta matogrossensis Moldenke & STM & x & x & & x & x & \\
Indeterminada & & & & & & & \\
Indeterminada sp1 & IND & & & & & \\
Indeterminada sp2 & & & & & & & \\
\hline
\end{tabular}




\section{Capítulo 2}

A vegetação das bancadas lateríticas em Corumbá e Ladário, MS e suas relações florísticas com as comunidades em afloramentos rochosos do Brasil

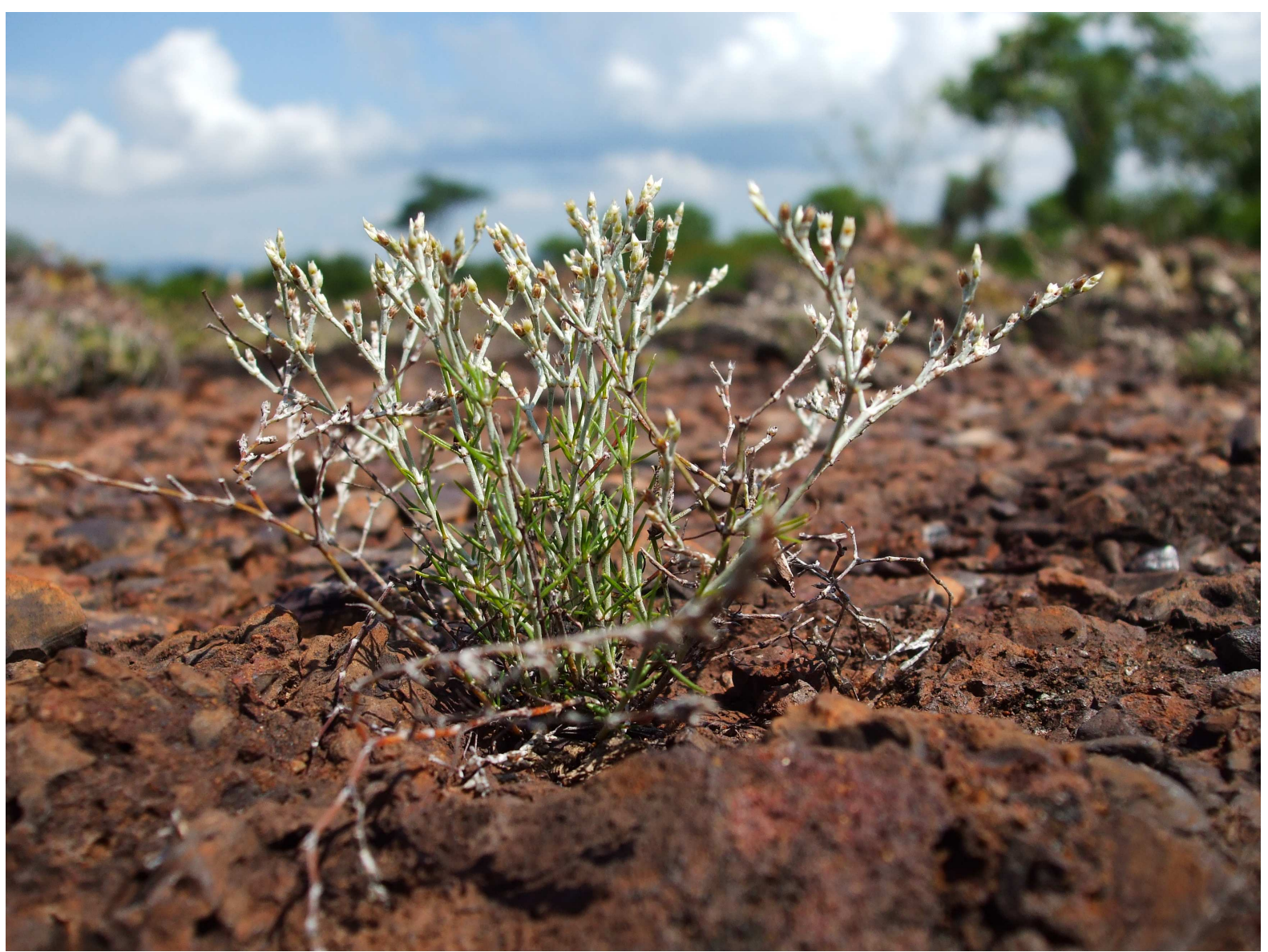

Polycarpaea corymbosa (L.)Lam. na Fazenda Banda Alta, Ladário, MS 


\section{Percepção}

Quando retornei

Meu cabelo ainda não era grisalho

E fiquei contente.

Os trabalhos das montanhas deixamos para trás.

Diante de nós estão os trabalhos das planicies.

Bertold Brecht (Alemanha, Augsburg, 1868 - Itália, Milão 1956; in: Poemas 1913-1956 - Sel. Trad. Paulo Cesar Souza, Brasiliense, 1990) 


\section{RESUMO}

Os afloramentos rochosos ferruginosos denominados bancadas lateríticas podem ser considerados uma paisagem peculiar no Centro-Oeste do Brasil, próximos às cidades de Corumbá e Ladário, MS. Embora situada em uma região populosa, próxima a fazendas e sítios urbanos, esta vegetação ainda é desconhecida. Neste estudo exploramos as relações florísticas entre afloramentos rochosos com diversos tipos de substratos e próximos a diferentes biomas. O levantamento foi

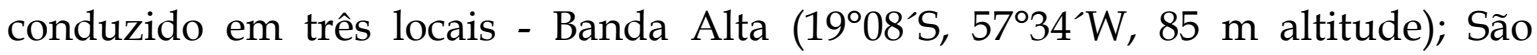

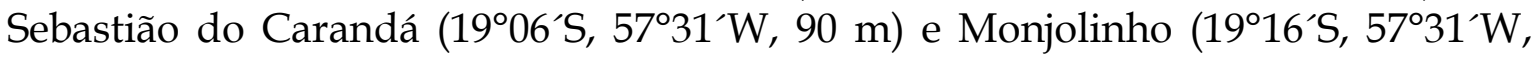
65-150 m). Dados de 40 localidades foram compilados em uma matriz com 2417 táxons baseados em listas de espécies publicadas de afloramentos graníticos, quartzíticos ou ferruginosos (cangas). As análises consideraram os níveis taxonômicos de famílias e gêneros. A detecção de padrões na composição florística foi baseada em técnicas de classificação e ordenação. A fonte de dados inicial consistiu de uma matriz binária de espécies por sítio. Táxons com uma única ocorrência foram descartados. Matrizes binárias secundárias, baseadas na matriz inicial, foram elaboradas contendo informações de gêneros e famílias por sítio. Para o procedimento de classificação, elaborou-se uma matriz de similaridade simétrica usando o índice de similaridade de Jaccard. Um procedimento de agrupamento aglomerativo hierárquico foi aplicado às matrizes de similaridade usando UPGMA como o algoritmo de agrupamento. Os métodos de ordenação de análises de correspondência na modalidade DCA e a análise de coordenadas principais foram aplicados para evidenciar os gradientes. Após a exclusão de táxons com uma única ocorrência obtivemos uma matriz operacional contendo 63 famílias e 217 gêneros. As famílias com maiores números de espécies nos afloramentos foram: Poaceae, Asteraceae, Orchidaceae, Fabaceae e Cyperaceae. Todas as análises destacaram a predominância do efeito do tipo do substrato. A maioria dos gradientes pode ser dividido em grupos pertencentes aos substratos de granito, cangas e quartzitos, com poucos pontos de sobreposição. Como uma evidente exceção aos sítios analisados, as bancadas lateríticas não se posicionaram no grupo formado pela maioria das cangas mas, sim, ao grupo de granitos da região da Caatinga. Este resultado aponta uma possível atuação paleoclimática no contato entre regiões florísticas disjuntas atualmente, tais como a Caatinga e as bancadas lateríticas.

Palavras-chave - afloramentos rochosos, similaridade florística, vegetação de Caatinga, canga, campos 


\section{ABSTRACT}

The ironstone outcrops called Bancadas Lateríticas can be considered a peculiar feature of the Central Brazil landscape nearby the cities of Corumbá and Ladário (MS). Although situated in a populated region, near farmlands and cities, the vegetation occurring on these outcrops is completely unknown. In this work we aim to explore the floristic relations among rock outcrops differing in substrate type and near different biomes. This survey was conducted in three outcrops -

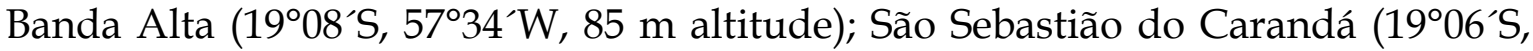

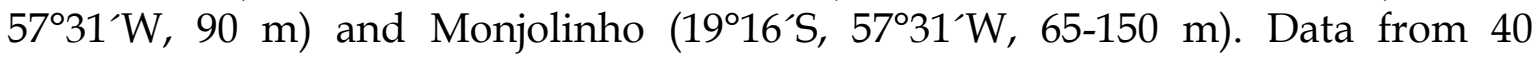
localities were compiled in a matrix of 2417 taxa based on published species lists from outcrops of granite, quartzite or ironstone (cangas). The entire analysis was performed using the taxonomical level of genus and family. The detection of patterns in taxonomical composition was based in classification and ordination techniques. The main data source was devised as a binary matrix of species per site. Taxa with only one occurrence were discarded. Binary secondary matrices, based on the main matrix were produced containing information of genera and families per site. For the classification procedure, a symmetrical similarity matrix was calculated using the Jaccard Similarity index. An agglomerative hierarchical clustering procedure was applied to the similarity matrices using UPGMA as the clustering algorithm. The ordination methods of Detrended Correspondence Analysis and Principal Coordinates were applied to enhance the resolution in detecting the gradients. After excluding the taxa with only one occurrence we ended up with a operational matrix containing 63 plant families and 217 genera. The families with the highest number of species in the outcrops were Poaceae, Asteraceae, Orchidaceae, Fabaceae and Cyperaceae. All the analyses point to a predominant effect of substrate type. Most of the gradients can be divisible in groups pertaining to granite, ironstone and quartzite substrates, with few overlaying points. As an evident exception the studied sites were not positioned in the group formed by most of the ironstone sites, instead, a recurrent pattern positioned the Bancadas Lateriticas among Granite outcrop sites of the Caatinga region. This result points to a possible role of paleoclimate in the contact of now disjunct floristic regions like the Caatingas and the Bancadas Lateriticas.

Keywords - rock outcrops, floristic similarity, Caatinga vegetation, canga, grassland 


\section{Introdução}

Os afloramentos rochosos são encontrados em todos os continentes, mas se concentram nas regiões tropicais úmidas ou semi-úmidas e, em menor grau, em regiões temperadas, como nos EUA (Barthlott et al. 1993a, Porembski et al. 1997, Porembski 2007). Nos neotrópicos distribuem-se pelo leste do Brasil, oeste da Venezuela e borda leste das Guianas, enquanto nos paleotrópicos ocorrem na África e Madagascar e, ainda, na Índia, Sri Lanka, China, Malásia e Austrália (Barthlott et al. 1993a).

Pelo fato de ocorrerem em topos de elevações como montanhas ou morros, acabam por vezes tidos como pontos turísticos (p.ex., Pão de Açúcar no Rio de Janeiro), ou nomearem lugares de igual apelo turístico como, por exemplo, a Chapada Diamantina, na Bahia. No Brasil, estão distribuídos por todas as formações vegetais sob diferentes condições climáticas, geológicas e geomorfológicas, com destaque para extensos conjuntos nas serras Do Mar, Da Mantiqueira, Cadeia do Espinhaço, Chapada dos Guimarães, entre outros, mas ainda pouco estudados do ponto de vista estrutural e florístico.

A vegetação que cresce sobre afloramentos rochosos foi enquadrada por Rizzini (1997) no tipo denominado "campos limpos", caracterizados por arbustos ou ervas xerófilas que se estabelecem em substratos rasos e/ou duros e secos. Veloso et al. (1991), por sua vez, aplicam o termo "refúgios vegetacionais" ou 
"relíquias de vegetação", já que esta fisionomia é floristicamente diferente do contexto geral da flora dominante.

Muitos trabalhos empregam a denominação genérica "vegetação sobre afloramento rochoso". Neste caso, a denominação envolve qualquer forma vegetacional encontrada sobre estruturas que apresentem rocha aparente, visto ser a proporção de rocha exposta um atributo importante no sítio. Esses sítios podem constituir desde pequenas áreas isoladas de rocha exposta em meio à vegetação instalada sobre solo desenvolvido até maciços inteiros em elevações ou superfícies planas extensas.

Alguns autores enquadram esta fisionomia vegetal no contexto de "complexos rupestres", sugerindo a utilização dos termos "complexos rupestres de quartzito" e "complexos rupestres de granito" para a vegetação que ocorre na Cadeia do Espinhaço e da Mantiqueira, respectivamente, designando a diferença do substrato sobre o qual se desenvolvem estas plantas (Semir 1991, Vincent \& Meguro 2008). Neste caso, abrangem diferentes tipos vegetacionais associados à vegetação rupestre, como as matas nebulares, escrubes, ambientes hidromórficos, além dos afloramentos rochosos.

As condições ambientais dos afloramentos rochosos assaz adversas para uma comunidade de plantas devem-se à grande amplitude térmica, às elevadas taxas de insolação, à inexistência ou exiguidade de solo e ao intenso déficit hídrico (Sarthou et al. 2009). Poucas espécies conseguem sobreviver a isso. Assim, os primeiros organismos a colonizar as rochas nuas são cianobactérias e líquens e, posteriormente, espécies poiquilohídricas ou suculentas se estabelecem em 
pequenas depressões, cavidades ou fissuras da rocha (Hambler 1964; Meirelles et al. 1999).

Graças à presença de primeiras plantas vasculares ali instaladas por conta de fatores como, principalmente, vento e água, além de outros (como dispersão de sementes por animais), raízes, ramos e folhas secas vão se acumulando, do que surge então um incipiente substrato no qual outras espécies vegetais - inclusive arbóreas - irão se estabelecer e tornar cada vez mais complexa a estrutura destas comunidades. Assim, aquelas desfavoráveis condições ambientais são tornadas amenas nos agrupamentos de vegetação (Conceição et al. 2007a), propiciando uma complexificação crescente do ambiente com o decorrer do tempo. Evidentemente, tal processo está sujeito a ser perturbado em maior ou menor grau por influências diversas, desde a ação do homem a fenômenos naturais (enxurradas, por exemplo).

As plantas estabelecem-se em quatro tipos principais de habitats nos afloramentos rochosos: superfície rochosa, fissuras, depressões e moitas (Seine et al. 1998) e, em função das peculiaridades de cada habitat, determinados grupos de plantas desenvolvem habilidades para colonizá-lo. Estes habitats podem ser subdivididos de acordo com as características do afloramento em estudo e dos objetivos da pesquisa, como por exemplo: vegetação criptogâmica, vegetação em canais de drenagem, vegetação efêmera durante a estação chuvosa, vegetação vascular litofítica, vegetação em fendas e fissuras, vegetação em poças sazonais, vegetação em fragmentos de rocha, vegetação em depressões preenchidas por 
solo, vegetação em moitas ou ilhas de solo (Barthlott et al. 1993b, Porembski et al. 1994, Porembski et al. 1997, Porembski 2007).

Face às características ambientais bastante restritivas às quais estão submetidas estas comunidades vegetais, espera-se certa similaridade entre os diferentes afloramentos rochosos ou, pelo menos, de alguns grupos funcionais. Este compartilhamento de espécies foi registrado por Porembski et al. (1994) na Guiné, África, entre afloramentos graníticos, ferruginosos e areníticos. Por outro lado, as características associadas à composição química da rocha subjacente passam a ser mais relevantes dada a impossibilidade de interações com outros elementos do solo e tamponamento das atividades químicas dos minerais componentes. Nesse sentido, a vegetação sobre afloramentos rochosos ferríferos sofre efeito da alta concentração de metais pesados e sua flora pode apresentar tolerância às condições extremas de solos metalíferos, consideradas tóxicas para a maioria dos vegetais (Porto \& Silva 1989, Silva 1992, Vincent \& Meguro 2008, Jacobi et al. 2007), podendo ser indiferente ao ambiente rico em metal pesado ou pouco afetada pela entrada de uma concentração mais elevada que o normal (Ginocchio \& Baker 2004). As condições peculiares no metabolismo destas plantas vêm sendo sugeridas para explicar a ocorrência de endemismos nos afloramentos ferríferos (Porto \& Silva 1989, Silva 1992) e locais com solos metalíferos (Ginocchio \& Baker 2004), onde algumas espécies de plantas poderiam ser utilizadas como indicadoras de jazidas de minerais (Ginocchio \& Baker 2004, Silva 1992, Baker \& Brooks 1988). 
No Brasil, os afloramentos rochosos podem ser enquadrados em grandes tipos geológicos: granito-gnaisses, quartzito-arenitos e cangas. A seguir, será apresentada uma breve revisão dos estudos de comunidades vegetais que se estabelecem sobre afloramentos rochosos segundo o tipo de litologia predominante.

Os afloramentos rochosos granítico-gnáissicos ocorrem em uma área vasta nas regiões sul, sudeste e nordeste do Brasil, muitas vezes destacando-se da paisagem como pontos turísticos, como o Pão de Açúcar no Rio de Janeiro. Entretanto, os estudos sobre a ecologia ou a florística destas comunidades rupícolas ainda são pouco numerosos. Destacam-se os estudos na Serra do Mar (Carauta \& Oliveira 1984, Porembski et al. 1998, Meirelles et al. 1999) e em campos de altitude de rochas graníticas e/ou rochas intrusivas ácidas ricas em sílica e alumínio da Serra da Mantiqueira (Caiafa \& Silva 2005, 2007), assim como sienogranitos no Rio Grande do Sul (Waldemar 1998). O semi-árido brasileiro apresenta "inselbergs" graníticos cujas comunidades foram estudadas por Queiroz et al. (1996), França et al. (1995, 1997, 2005, 2006), Araújo et al. (2008), Porto et al. (2008) e Gomes \& Alves (2009). De modo geral, as formações rochosas por vezes isoladas na paisagem têm sido chamadas de "inselbergs" por transliteração do termo empregado nos trabalhos de Barthlott et al. (1993b), Porembski et al. (1994, 1998), Porembski \& Barthlott (2000), Porembski (2007). Entretanto, o termo possui emprego específico na literatura geomorfológica e corresponde a estruturas resultantes de pediplanação resultante de intemperismo sob condições de clima semi-árido (Maio 1987). Dado o uso frequente na literatura sobre afloramentos 
rochosos o termo passou a ser empregado no seu sentido etimológico que sugere a presença de uma elevação rochosa isolada sem preocupação com o significado geomorfológico estrito.

Os afloramentos rochosos ferruginosos estão sob grande pressão antrópica devido à exploração de minério de ferro e, por este motivo, sofrem com a eliminação destes habitats e de suas comunidades vegetais. No Brasil, destacam-se os estudos em cangas da Serra do Carajás (Secco \& Mesquita 1983, Silva 1991, Silva et al. 1996, Rayol 2006) e da região do Quadrilátero Ferrífero em Minas Gerais (Brandão et al. 1989, Brandão \& Gavilanes 1990, Brandão 1992, Jacobi et al. 2007, Mourão \& Stehmann 2007, Viana \& Lombardi 2007, Jacobi et al. 2008, Vincent \& Meguro 2008). Já a vegetação sobre afloramentos rochosos ferríferos na região da Morraria do Urucum, em Corumbá, no Estado de Mato Grosso do Sul é estudada pela primeira vez no presente trabalho (Capítulo 1).

Quanto a flora dos afloramentos rochosos quartzítico-areníticos dos "complexos rupestres" ou "campos rupestres", esta vem sendo abordada em diversos estudos taxonômicos (p.ex. Giulietti et al. 1987, Peron 1989, Gavilanes \& Brandão 1991, Brandão 1992, Zappi et al. 2003). Não obstante, estudos das comunidades que se estabelecem em afloramentos rochosos quartzítico-areníticos são escassos, dentre os quais se destacam os conduzidos por Conceição \& Giulietti (2002), Conceição et al. (2007a, 2007b), Neves \& Conceição (2007), Vincent \& Meguro (2008) e Albergaria (2009).

Outros tipos de litologias, como afloramentos basálticos, foram estudados em Altinópolis, SP (Oliveira \& Godoy 2007) e no Rio Grande do Sul (Bauer \& 
Larocca 2003), enquanto rochas de nefelina-sienito foram estudadas por Ribeiro et al. (2007) em Itatiaia e morros testemunhos areníticos foram estudados na região de Porto Alegre (Fernandes \& Baptista 1988, 1999).

Este trabalho buscou comparar a flora das cangas de Corumbá com outras comunidades vegetais sobre afloramentos rochosos brasileiros. E os objetivos visaram responder a estas duas questões:

1. Qual o grau de similaridade entre a vegetação sobre os afloramentos rochosos ferruginosos de Corumbá, MS, e as comunidades vegetais dos afloramentos rochosos do Brasil nos níveis taxonômicos de famílias e gêneros?

2. A natureza do substrato (quartzítico-areníticos, granítico-gnáissicos e cangas) influencia a similaridade florística de diferentes afloramentos rochosos no Brasil? 


\section{Material e Métodos}

\section{Área de estudo}

O presente realizou-se em afloramentos rochosos ferruginosos, também denominados "bancadas lateríticas", localizados nas áreas de drenagem (em torno de 100 m de altitude) das Morrarias do Urucum e do Rabicho, municípios de Corumbá e Ladário, MS (Figura 1).

As bancadas lateríticas são consideradas não um tipo de solo, mas um tipo de relevo plano ou quase plano, formado por material laterítico endurecido, de natureza ferrífera (Cardoso et al. 2000), com pouca vocação para usos agrícolas ou pastoris (Pott et al. 2000). Essas áreas com superfície rochosa ferrífera exposta possuem, em seu interior, depressões, fendas ou cavidades com pequeno acúmulo de sedimentos, sobre os quais se estabelece uma vegetação herbáceo-arbustiva (Figura 2). Ao redor destes lajedos encontram-se matas estacionais em diferentes níveis de degradação ou pastagens.

A região do Maciço do Urucum, na área estudada, assenta-se sobre o embasamento Gnáissico-Granítico com o Grupo Cuiabá e o Grupo Jacadigo na sequência estratigráfica (Haralyi \& Walde 1986, Anjos \& Okida 2000). Este último é constituído pela Formação Urucum (conglomerados com granitos, gnaisses, calcários e micaxistos) e pela Formação Santa Cruz (camadas de arcóseos com nódulos de criptomelano e criptomelano compacto, ricos em manganês e hematita), explorada comercialmente na região para extração de ferro e manganês. 
De modo geral, toda superfície onde está a vegetação é formada pela cobertura dendrítico-laterítico pleistocênica composta por sedimentos conglomeráticos e depósitos de talus com predominância de minérios de ferro. Nas áreas de planície essa cobertura forma uma carapaça (bancada) laterítica que se situa, em geral, na base dos solos de toda área de influência da sedimentação dos morros, aflorando nas áreas de linha de drenagem das águas (Brasil 1982, Haralyi \& Walde 1986, Anjos \& Okida 2000).

O clima de Corumbá é do tipo Awa, segundo a classificação de Koppen, correspondendo a um clima tropical de altitude megatérmico (a temperatura do mês mais frio é superior a $18^{\circ} \mathrm{C}$ ) com inverno seco e chuvas no verão (Soriano 2000). A precipitação anual de Corumbá, para o período de 1976 a 1996, foi de $1070 \mathrm{~mm}$ anuais e temperatura média anual de 25,1ㅇ (Soriano 2000).

Os trabalhos de campo desenvolveram-se com periodicidade mensal de novembro de 2005 a abril de 2007 e, bimestralmente daí em diante, até janeiro de 2009 em duas fazendas localizadas no município de Ladário e em uma fazenda no município de Corumbá, MS.

As fazendas visitadas em Ladário foram a “Banda Alta” (1908`S, 57³4`W, 85 m) e a "São Sebastião do Carandá" (1906’S, 57³1’W, 90 m), distantes cerca de 20 e 25 quilômetros respectivamente da cidade de Corumbá e acessadas por terra apenas pela Rodovia MS-228, tornada Área Especial de Interesse Turístico (Decreto Estadual n. 7122, de 17 março de 1993) pelo Governo do Estado de Mato Grosso do Sul, com a denominação "Estrada Parque Pantanal”. 
Já o único estabelecimento rural visitado no município de Corumbá foi a

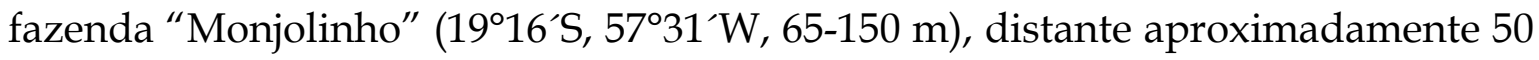
quilômetros da cidade de Corumbá, cujo acesso se dá pela rodovia federal BR-262 (Figura 1).
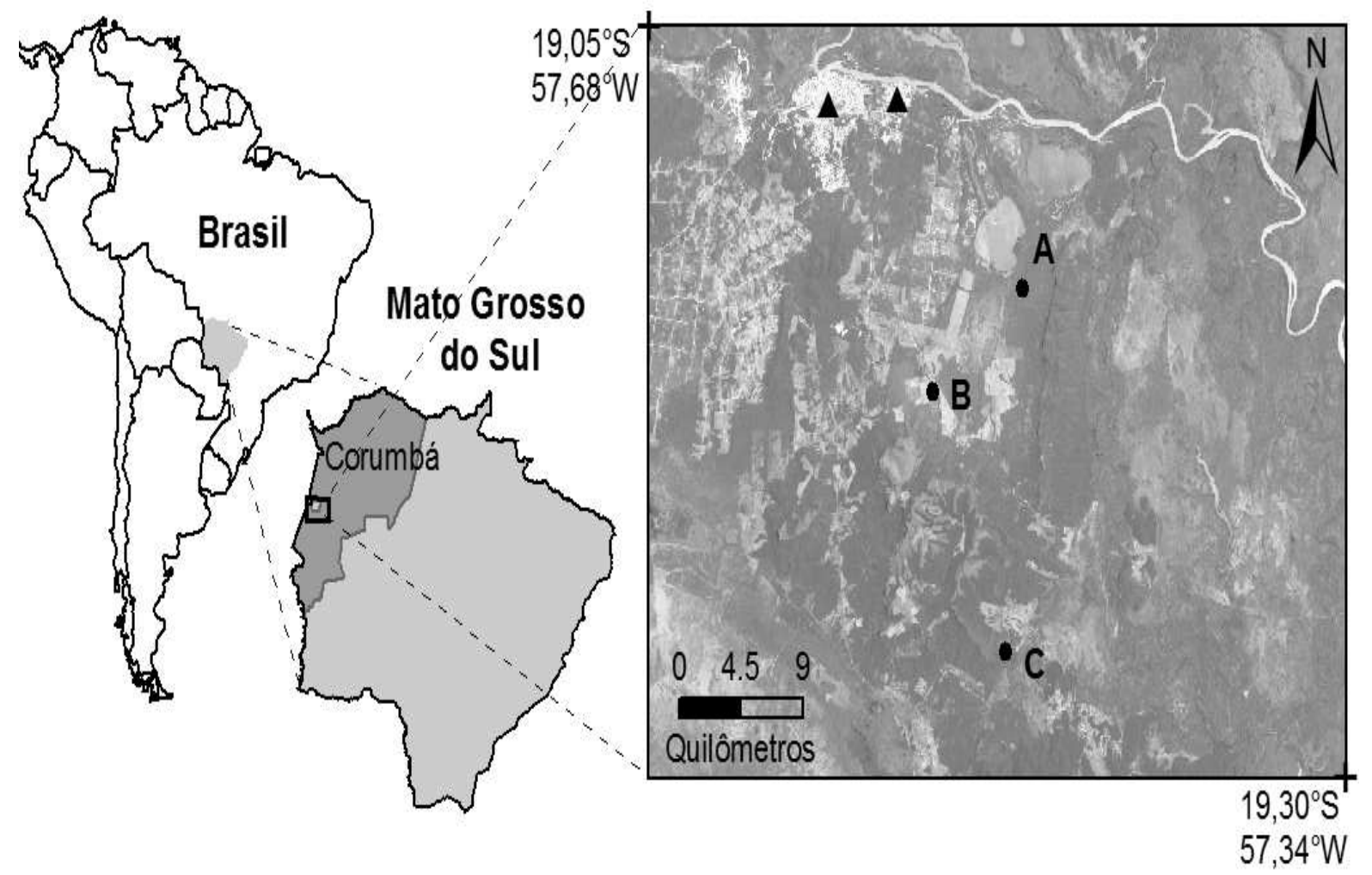

Figura 1 - Localização do Estado de Mato Grosso do Sul, do município de Corumbá, MS e das três áreas de estudo. No detalhe observam-se os sítios urbanos das cidades de Corumbá e Ladário (triângulos) e as três áreas de estudo localizadas no sopé da Morraria do Urucum: A=Fazenda São Sebastião do Carandá, B=Fazenda Banda Alta e C=Fazenda Monjolinho. Fonte: INPE, imagem do satélite Landsat 5 TM, de 1 de novembro de 2009, composição colorida RGB321. Elaborado por: Leandro Tambosi. 


\section{Coleta de dados}

Foram definidos dois tipos de ocupação pela vegetação de afloramentos rochosos ferríferos: a) estrato herbáceo contínuo sobre a superfície rochosa sem ser possível delimitar os agrupamentos de plantas e b) vegetação que ocorre nas ilhas de solo (Burbanck \& Platt 1964, Ibisch et al. 1995, Meirelles et al. 1999, Conceição \& Pirani 2005, Medina et al. 2006) (Figuras 2a, 2b). A vegetação do estrato herbáceo estabelecida sobre a rocha foi avaliada em 199 parcelas de 1 × $1 \mathrm{~m}$, distribuídas aleatoriamente no interior nas bancadas lateríticas, sendo 81 parcelas na Fazenda Banda Alta, 60 na Fazenda São Sebastião do Carandá e 58 na Fazenda Monjolinho (ver Capítulo 1 para maiores detalhes e lista de espécies). A vegetação em ilhas de solo foi amostrada em 164 unidades, sendo 70 na Fazenda Banda Alta, 28 na Fazenda São Sebastião do Carandá e 66 na Fazenda Monjolinho.

O material-testemunho foi depositado no Herbário COR (UFMS, campus do Pantanal, Corumbá, MS), com duplicatas aos especialistas que identificaram o material. A circunscrição de famílias baseou-se em APG II (APG 2003) e o nome dos autores de espécies foi verificado em Brummitt \& Powell (1992). Os especialistas consultados para confirmação da identificação do material botânico foram: Adriana Guglieri (Poaceae, UFMS), Ana Maria Goulart de Azevedo Tozzi (Leguminosae, UNICAMP), Cintia Kameyama (Acanthaceae, Instituto de Botânica São Paulo), Claudia Elena Carneiro (Caryophyllaceae, UEFS), Elton M. Assis (Ophioglossaceae, Polypodiaceae, Pteridaceae, Schizaeaceae, Selaginellaceae, UFMS), Gerleni Lopes (Malvaceae s.l. , Instituto de Botânica São Paulo), Juliana Lovo (Iridaceae, USP), Kikyo Yamamoto (Ochnaceae, UNICAMP), Luiza S. 
Kinoshita (Apocynaceae, UNICAMP), Marcela Firens (Rubiaceae, UNICAMP), Marcos José da Silva (Euphorbiaceae, Phyllanthaceae, UNICAMP), Maria Ana Farinaccio (Asclepioideae, USP), Maria Candida Mamede (Malpighiaceae, Instituto de Botânica São Paulo), Maria do Carmo Amaral (Commelinaceae, UNICAMP), Osny Tadeu Aguiar (Myrtaceae, Instituto Florestal de São Paulo), Rafael Trevisan (Cyperaceae, UFRGS), Renata Oliveira (Amaryllidaceae, UNICAMP), Renata Sebastiani (Malpighiaceae-Janusia, Instituto de Botânica São Paulo), Rosangela Simão Bianchini (Convolvulaceae, Instituto de Botânica São Paulo), Roseli Torres (Cannabaceae, Salicaceae, IAC-Campinas), Rosilene Silva (Leguminosae, UNICAMP), Rubens T. Queiroz (Leguminosae, UNICAMP) e Washington Marcondes Ferreira (Apocynaceae-Aspidosperma, Combretaceae, UNICAMP). 


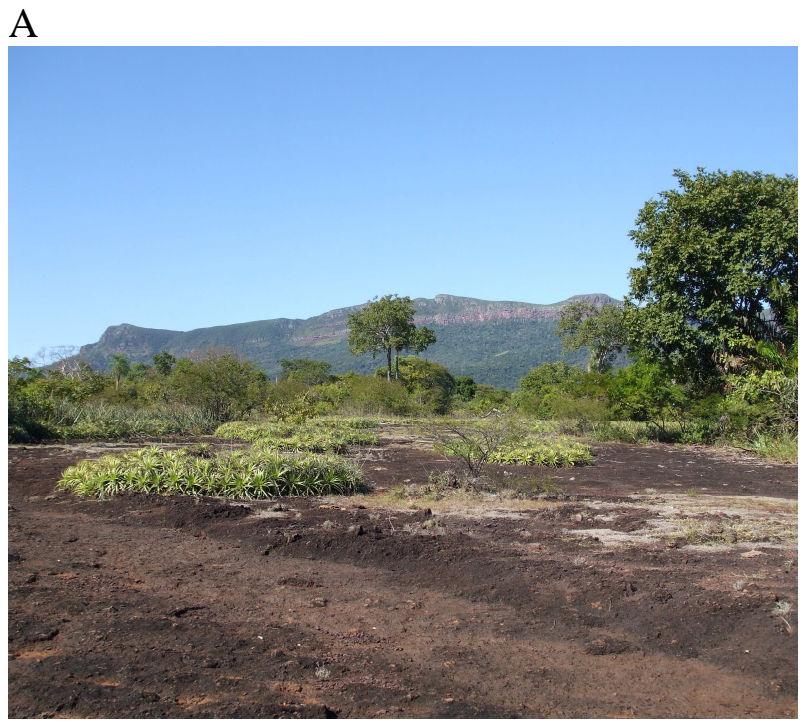

$\mathrm{C}$

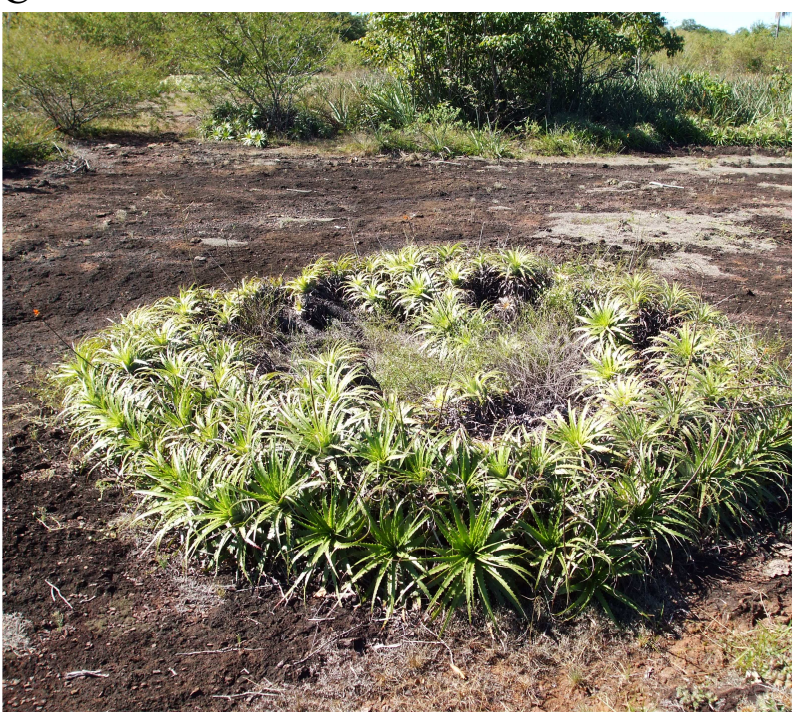

B

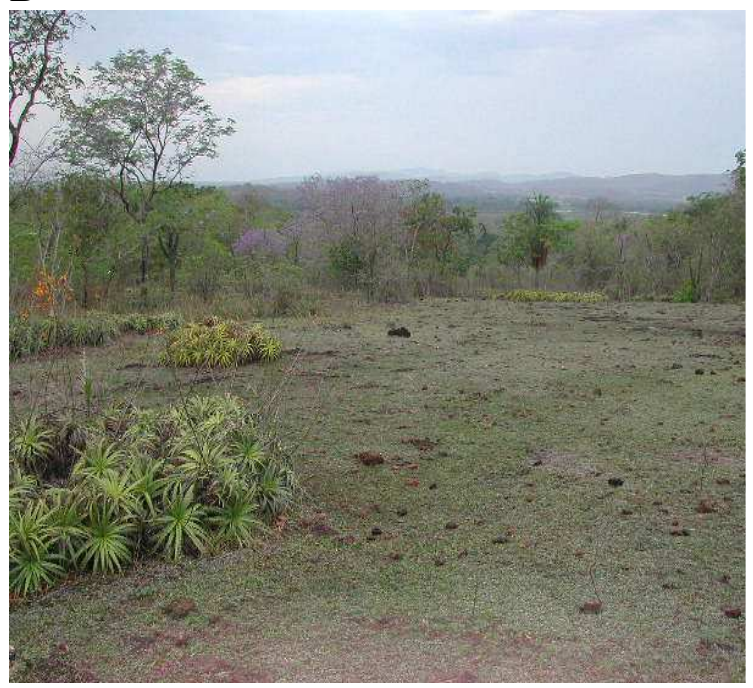

$\mathrm{D}$

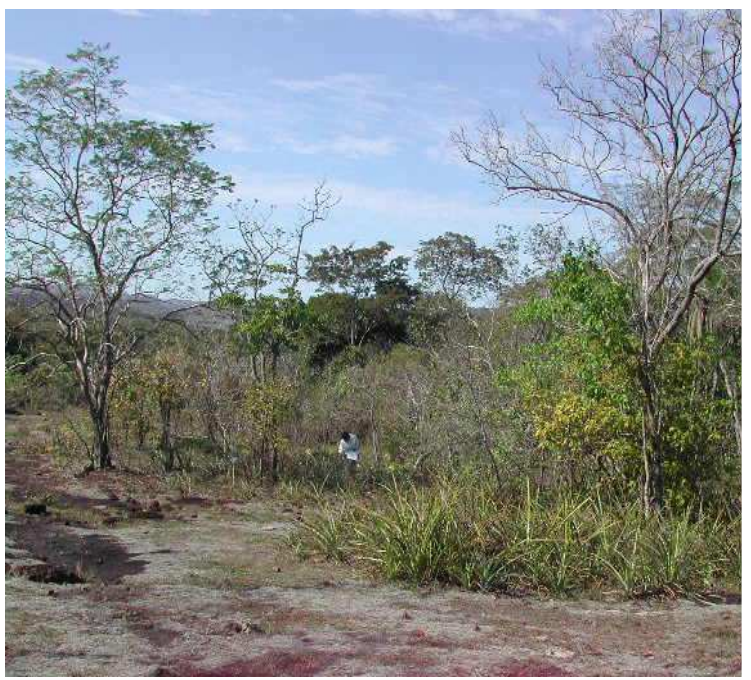

Figura 2a - Aspecto geral dos afloramentos rochosos ferruginosos em Corumbá e Ladário, MS. A) as cangas ocorrem no sopé da Morraria do Urucum onde é possível visualizar a superfície rochosa e algumas ilhas de solo e, ao fundo, a mata estacional que circunda estes lajedos, B) vegetação contínua onde a superfície rochosa é recoberta pelo estrato herbáceo, C) ilha de solo com Deuterocohnia meziana, D) em primeiro plano, ilha de solo florestal com Bromelia balansae, 


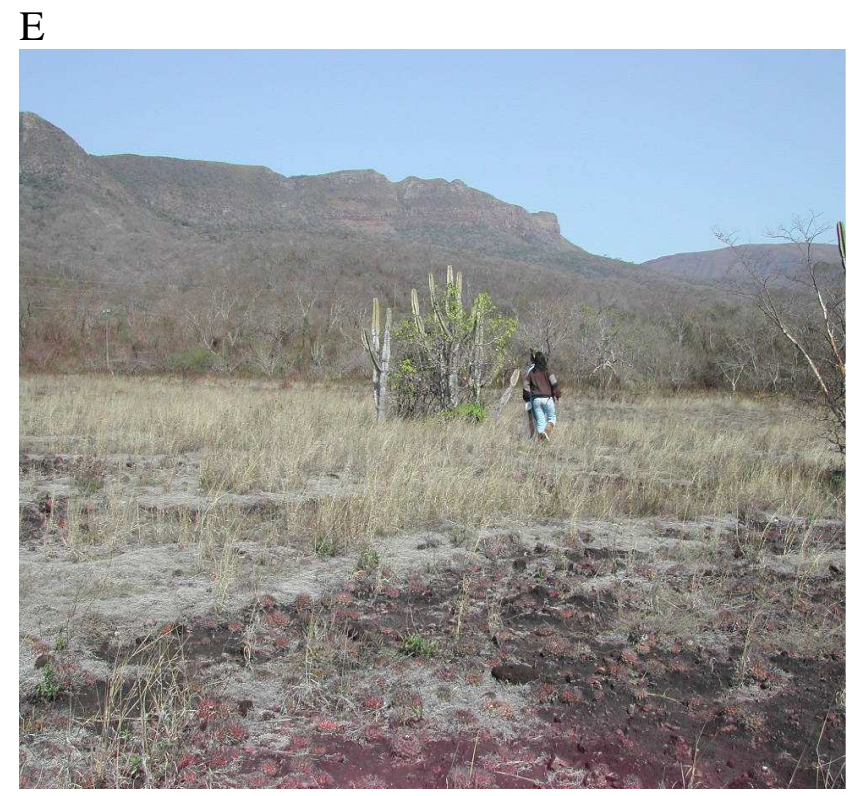

G

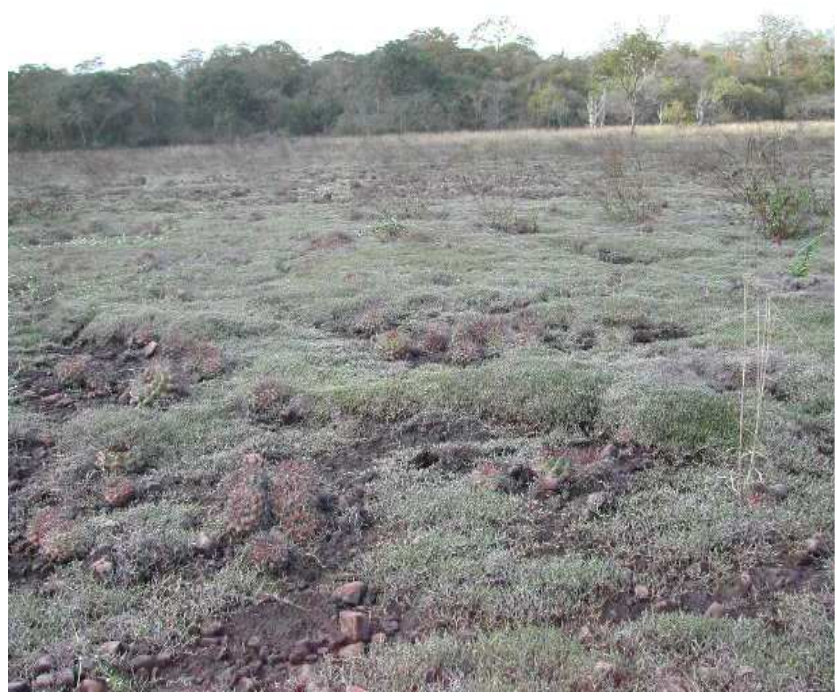

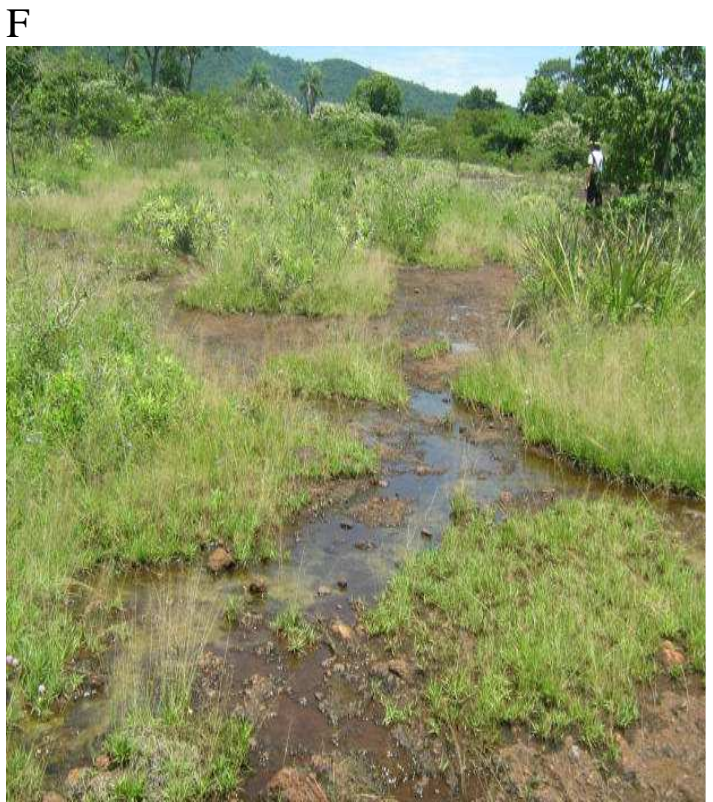

$\mathrm{H}$

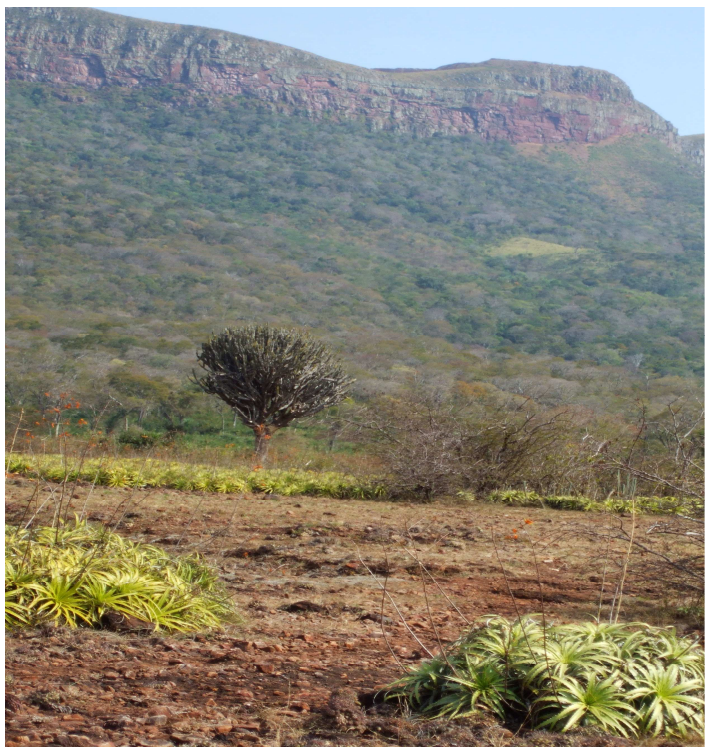

Figura $2 \mathrm{~b}$ - Aspecto geral dos afloramentos rochosos ferruginosos em Corumbá e Ladário, MS. E) aspecto da vegetação durante a estação seca com destaque para Cereus bicolor, F) vista de córrego temporário durante a estação chuvosa onde plantas efêmeras e associadas a locais mais úmidos se estabelecem onde há acúmulo de substrato. G) Irregularidade do substrato rochoso, H) ilhas de Deuterocohnia meziana, um exemplar de Cereus bicolor em destaque e a Morraria do Urucum ao fundo. Fotos: Adriana Takahasi. 


\section{Análise de dados}

A matriz inicial com 2.417 táxons foi elaborada a partir da compilação de listas de espécies de angiospermas amostradas em 40 habitats nos afloramentos rochosos do Brasil (ver Anexo), incluindo a deste trabalho (Capítulo 1). Ambientes distintos dentro de uma mesma localidade (p.ex. canga nodular e canga couraçada) foram considerados separadamente. Na elaboração desta matriz, as espécies que constavam como "cf." (identificação a conferir) e os táxons determinados apenas até o nível genérico foram considerados apenas em nível genérico; as espécies registradas como "aff." (affinis) foram consideradas em nível de espécie. Alterações recentes na taxonomia e nomenclatura foram aplicadas para artigos mais antigos a fim de permitir a comparação entre diferentes localidades, procedendo-se à sinonimização das espécies através de consulta às páginas da internet do "The Missouri Botanical Garden" (www.tropicos.org), "The International Plant Names Index" (www.ipni.org) e do "Flora Brasiliensis" hospedado na página do Centro de Referência em Informação Ambiental (florabrasiliensis.cria.org.br).

O uso de dados secundários neste tipo de trabalho sem consulta aos herbários pode sabidamente prover identificações taxonômicas incorretas, embora este erro tenha sido minimizado por meio da exclusão daquelas espécies com uma única ocorrência nas análises de agrupamento e ordenação. Cabe destacar, ainda, que existem limitações nas inferências e generalizações ao se comparar trabalhos com diferentes metodologias de coleta de dados, diferentes tamanhos amostrais, objetivos e critérios de inclusão. Não obstante, o presente estudo oferece-se como 
uma primeira abordagem sobre a semelhança florística entre os afloramentos rochosos do Brasil em nível de famílias e gêneros.

Para verificar afinidades na composição florística da vegetação amostrada nos diversos afloramentos rochosos brasileiros efetuou-se uma análise de agrupamento com emprego de um método hierárquico aglomerativo aplicado à matriz de dados de presença e ausência em dois níveis taxonômicos: famílias e gêneros. Na condução da análise foram retirados da matriz os táxons com uma única ocorrência a fim de eliminar ruídos e "outliers". A análise de cluster foi executada através do coeficiente de similaridade de Jaccard com o algoritmo UPGMA aplicado às matrizes de dados para 63 famílias de angiospermas e 217 gêneros em 40 habitats.

Duas análises multivariadas foram aplicadas no exame das relações observadas a partir do procedimento de agrupamento: a) análise de coordenadas principais (PCO) empregando-se a distância de Gower b) análise de correspondência na modalidade DCA empregando-se o algoritmo de Hill com a correção de tendência (detrending) empregando-se a partição em 26 segmentos para recálculo com 100 iterações. Estas duas análises basearam-se na matriz de presença/ausência de gêneros e de famílias em cada localidade/habitat nos afloramentos rochosos, com auxílio do programa MVSP for Windows versão 3.1 (Kovach Computing Services). As correlações de Pearson para as localidades e os escores dos táxons dos primeiros eixos da PCO e da DCA foram calculadas para avaliar quais os táxons contribuíram para a ordenação das localidades, com auxílio do programa SPSS 13.0 for Windows (SPSS, Chicago, Illinois, EUA). 


\section{Resultados}

\section{Análise florística para as famílias amostradas em afloramentos rochosos}

As famílias com maior número de ocorrências de espécies naqueles 40 habitats foram: Poaceae (174 ocorrências), Asteraceae (165), Orchidaceae (111), Fabaceae (105) e Cyperaceae (86).

O dendrograma resultante da análise de cluster para as 63 famílias botânicas observadas nesses 40 habitats inseriu a vegetação das bancadas lateríticas em um grupo formado pelos afloramentos rochosos de Pernambuco e Ceará, ao qual se associou um grupo de afloramentos de granitos na Bahia e no Rio de Janeiro, mas não junto às demais cangas que ocorrem no País (Figura 3).

A análise do nível hierárquico de famílias botânicas permitiu notar, grosso modo, dois grupos formados por afloramentos granítico-gnáissicos e um grande grupo formado por cangas associadas aos quartzito-arenitos (Figura 3) sendo que a vegetação rupícola de Itatim, Bahia, e os ambientes de borda de escrube e de campo graminoso estudados por Caiafa \& Silva (2005) foram os primeiros locais a se separarem nesta análise de agrupamento (coeficiente de similaridade=0,222).

O primeiro grupo desta análise foi formado pelas comunidades em afloramentos granítico-gnáissicos, sob clima mais quente, da Bahia e Rio de Janeiro associados àquelas em afloramentos de Pernambuco, Ceará e de cangas em Corumbá, com $23 \%$ de similaridade. Um segundo grupo de afloramentos de granito-gnaisses, sob temperaturas aparentemente mais baixas, foi formado pelas 
comunidades rupícolas de Itatiaia (nefelina-sienito) e Serra do Brigadeiro associadas à vegetação nos afloramentos do Rio Grande do Sul (granitos, arenitos e basalto), com 32\% de similaridade. Observou-se, ainda, um terceiro grupo formado pelos afloramentos de cangas e de quartzito-arenitos, com $31 \%$ de similaridade, sendo que a vegetação do Parque Estadual do Rola Moça foi o primeiro grupo a se separar. Quanto a este último grupo, observou-se um subgrupo formado pelas cangas amazônicas associadas ao afloramento basáltico em Altinópolis (coeficiente de similaridade=0,448), e outro subgrupo formado pelas cangas de Minas Gerais associados às comunidades rupícolas dos quartzitoarenitos da Chapada Diamantina, de Carajás (Secco \& Mesquita 1983) e dos granitos de Atibaia (coeficiente de similaridade=0,388) (Figura 3). 


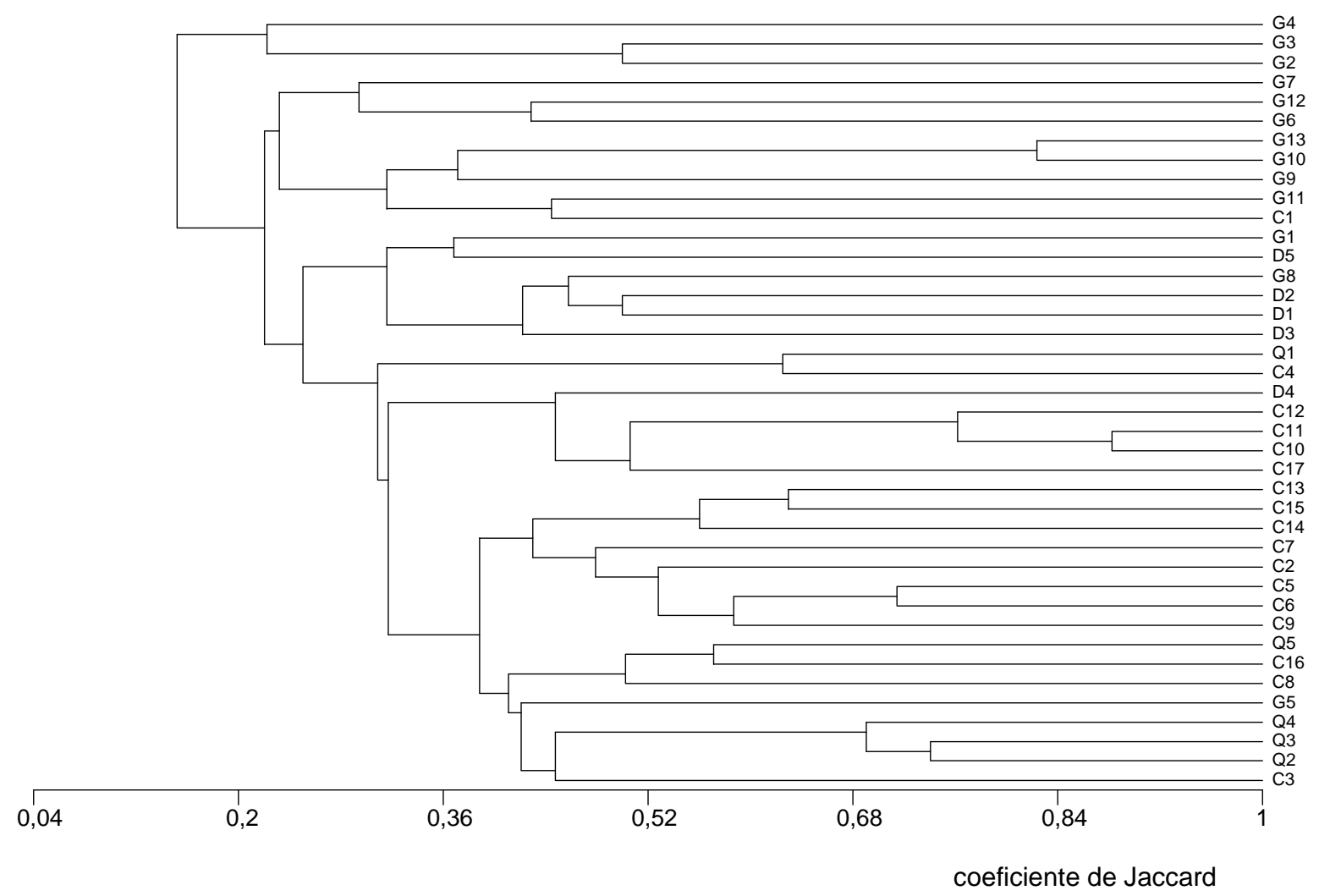

Figura 3 - Dendrograma elaborado a partir da matriz binária de 63 famílias botânicas em 40 habitats em afloramentos rochosos no Brasil, utilizando-se o índice de similaridade de Jaccard e UPGMA (para abreviatura das localidades ver Anexo). 
O resultado da análise de $\mathrm{PCO}$ aplicada à matriz de famílias permitiu uma representação da informação contida na matriz de 30,4\% nos dois primeiros eixos, correspondendo, respectivamente a 17,5\% e 12,9\%. A interpolação dos escores correspondentes a estes dois eixos mostrou uma polarização entre granitos e cangas ao longo do eixo 1 com os afloramentos de quartzito-arenitos ocupando uma posição intermediária (Figura 4), devido à presença de componentes das famílias Fabaceae $(\mathrm{r}=0,772)$, Rubiaceae $(\mathrm{r}=0,7713)$ e Verbenaceae $(\mathrm{r}=0,742)$ polarizando com a família Aristolochiaceae ( $\mathrm{r}=-0,3663)$, conforme as correlações de Pearson. 


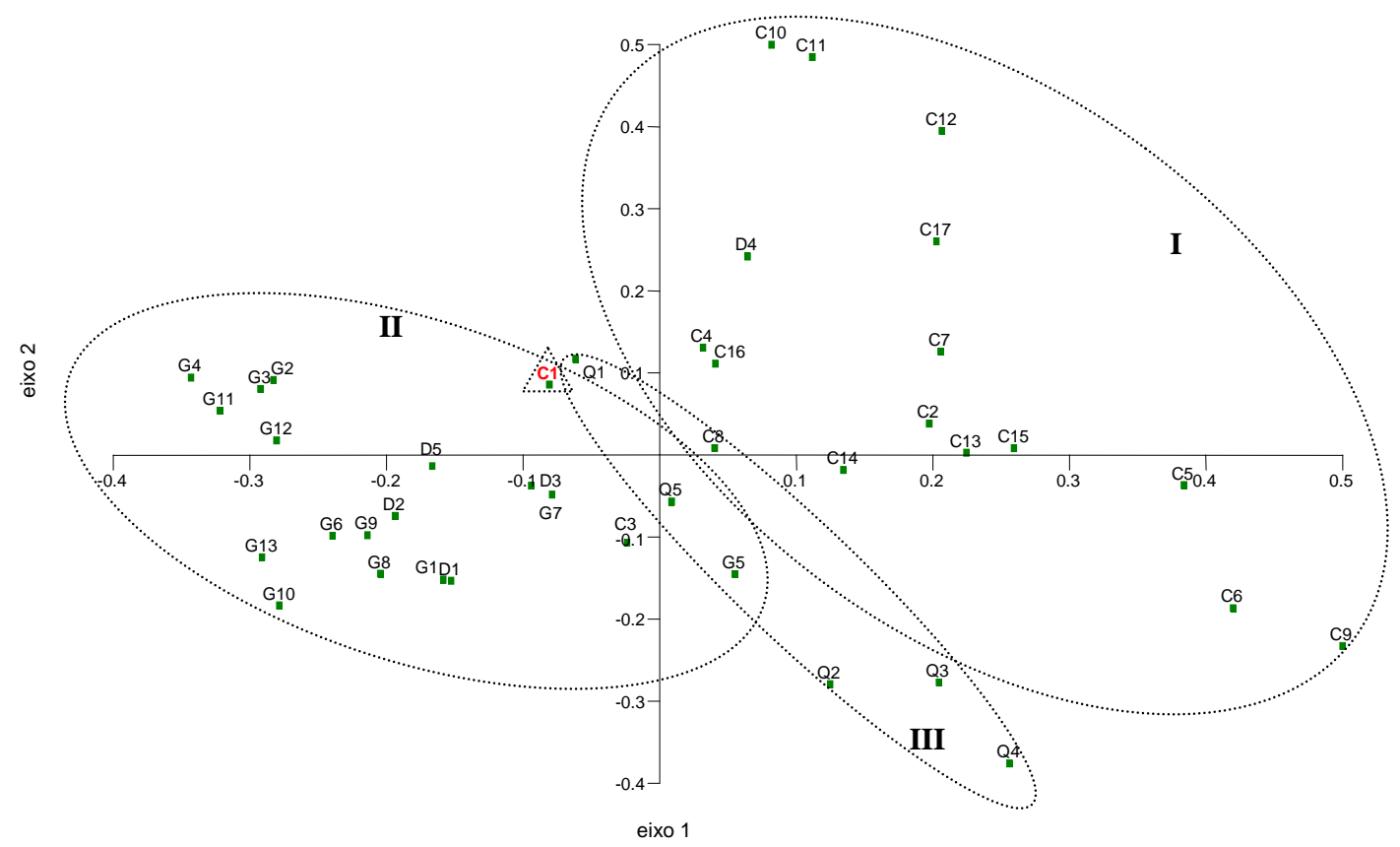

Figura 4 - Interpolação de escores dos eixos 1 e 2 resultantes da análise de PCO aplicada à matriz de 63 famílias botânicas presentes em 40 habitats em afloramentos rochosos do Brasil (para abreviatura das localidades ver Anexo). As elipses agrupam as localidades segundo a litologia dominante, onde I=cangas, II=granito-gnaisses, III=quartzito-arenitos, enquanto o triângulo destaca as cangas de Corumbá.

O resultado da análise de DCA aplicada à matriz de famílias permitiu uma representação da informação contida na matriz de 20,4\% nos dois primeiros eixos, correspondendo, respectivamente a $13 \%$ e 7,4\%. A interpolação dos escores correspondentes aos dois primeiros eixos permitiu visualizar a polarização entre granitos e cangas ao longo do eixo 1 em função da presença de componentes de Malpighiaceae $(\mathrm{r}=0,7401), \quad$ Annonaceae $(\mathrm{r}=0,6857)$ e Rubiaceae $(\mathrm{r}=0,6717)$ polarizando com a família Aristolochiaceae $(r=-0,4987)$ indicados pelas análises de correlação de Pearson. A segregação entre os afloramentos de granito-gnaisses do 
nordeste brasileiro dos afloramentos em Itatiaia, na Serra do Brigadeiro e no Sul do Brasil foi observada ao longo do eixo 2 (Figura 5).

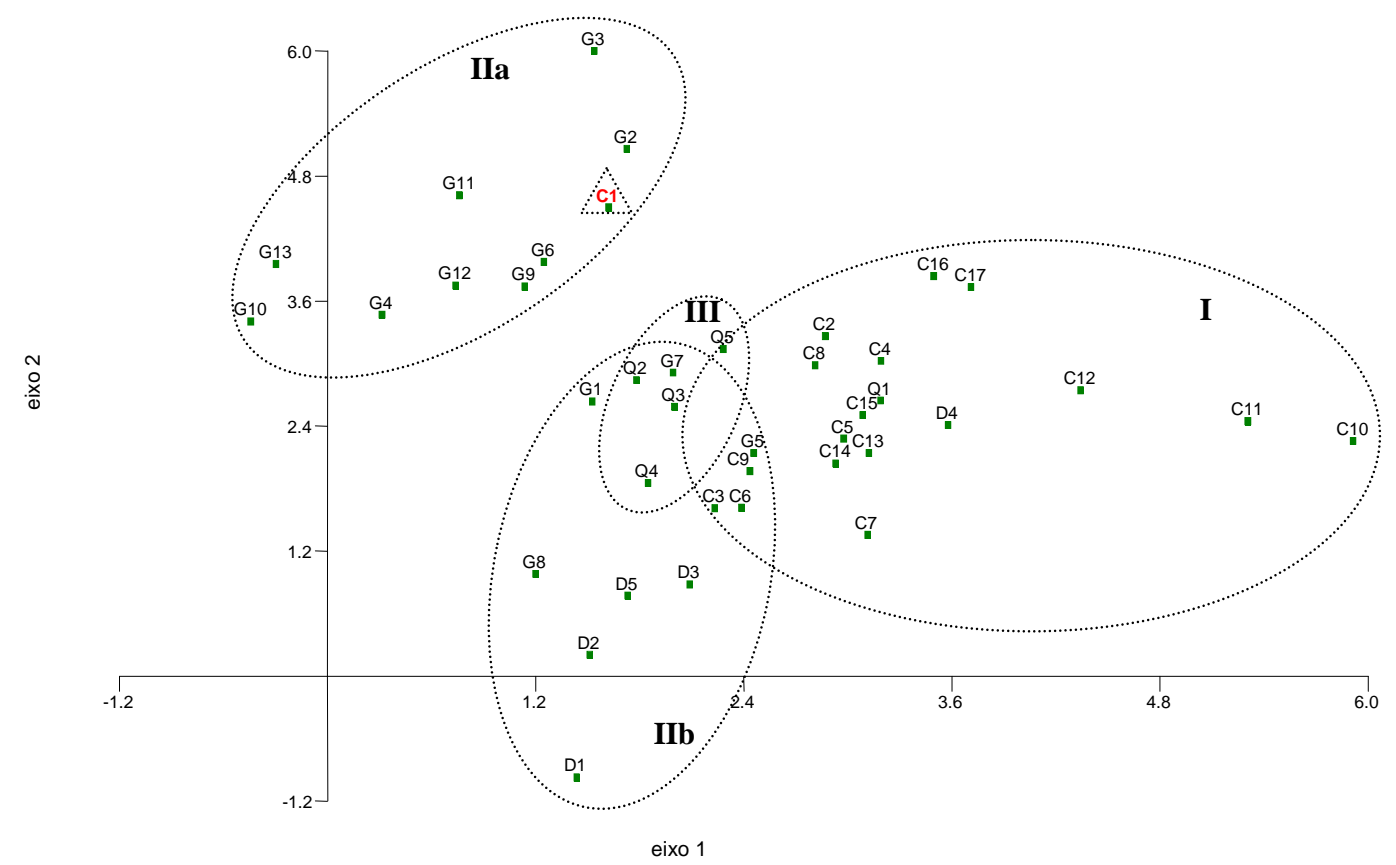

Figura 5 - Interpolação dos eixos 1 e 2 resultantes da análise de DCA aplicada à matriz de 63 famílias botânicas presentes em 40 habitats em afloramentos rochosos do Brasil (para abreviatura das localidades ver Anexo). As elipses agrupam as localidades segundo a litologia dominante, onde I=cangas, IIa=granito-gnaisses em locais com temperaturas mais elevadas, IIb=granito-gnaisses com temperaturas mais baixas, $\mathrm{III}=$ quartzito-arenitos, enquanto o triângulo destaca as cangas de Corumbá. 


\section{Análise florística para os gêneros amostrados em afloramentos rochosos}

Os gêneros com maior número de ocorrências de espécies nos 40 habitats em afloramentos rochosos analisados foram: Axonopus (22 ocorrências), Baccharis e Andropogon (21 cada), Tillandsia (20), Tibouchina e Mellinis (19 cada).

O dendrograma resultante da análise de cluster para os 217 gêneros amostrados inseriu a flora das bancadas lateríticas junto à dos afloramentos rochosos do semi-árido em um resultado similar ao observado para a análise das famílias botânicas (Figura 6).

Esta análise revelou a formação de dois grandes grupos: a vegetação dos granitos do Nordeste e Rio de Janeiro, e outro grupo com as comunidades dos demais afloramentos rochosos (coeficiente de similaridade $=0,057$ ). $O$ primeiro grupo observado nesta análise foi formado pelas comunidades rupícolas dos afloramentos da Bahia e do Rio de Janeiro associadas às comunidades das cangas de Corumbá e dos granitos do Nordeste (Pernambuco e Ceará) (coeficiente de similaridade $=0,082)$.

Para a vegetação dos demais afloramentos rochosos viu-se que as comunidades no Rio Grande do Sul (granito, arenito, basalto) foram as primeiras a se separar (coeficiente de similaridade=0,145). Em seguida, a vegetação de campos de altitude de Itatiaia e da Serra do Brigadeiro se separou dos demais (coeficiente de similaridade=0,189). Observou-se, ainda, um grupo formado pelas cangas de Carajás (coeficiente de similaridade=0,317). Por fim, assomou à análise um grupo formado pela vegetação de afloramentos quartzítico-areníticos (coeficiente de similaridade $=0,217$ ) e outro grupo formado pelas comunidades rupícolas dos 
afloramentos rochosos de Minas Gerais, granitos de Atibaia e dos basaltos em Altinópolis (coeficiente de similaridade=0,149) (Figura 6).

Nesta análise de agupamento, os conjuntos formados pelas cangas de Carajás, pelos quartzito-arenitos da Chapada Diamantina e pelos três habitats da Serra do Brigadeiro revelaram-se similares entre si, o que não havia sido observado na análise das famílias botânicas. Outra diferença constatada por esta análise foi a similaridade entre a vegetação de Atibaia e da Chapada Diamantina em nível de família, enquanto em nível de gêneros a comunidade rupícola de Atibaia foi mais similar à de Altinópolis, e, por sua vez, a flora de Altinópolis foi mais similar à de Carajás em nível de família.

O resultado da análise de $\mathrm{PCO}$ aplicada à matriz de gêneros permitiu uma representação da informação contida na matriz de $26,1 \%$ nos dois primeiros eixos, correspondendo, respectivamente a 15,8\% e 10,3\%. A interpolação dos escores correspondentes aos dois primeiros eixos mostrou um gradiente curto para as comunidades vegetais sobre granitos, diferentemente da matriz de famílias, e um gradiente longo para a vegetação sobre cangas ao longo do eixo 1 ao passo que a vegetação sobre quartzito-arenitos posicionou-se no lado negativo do eixo 2 (Figura 7). Os gêneros que determinaram a configuração da distribuição das localidades ao longo do eixo 1 foram: Habranthus ( $r=0,7827)$, Galactia $(r=0,7483)$ e Eriope $(\mathrm{r}=0,7385)$ polarizando com Encholirium $(\mathrm{r}=-0,3179)$ através das correlações de Pearson. 


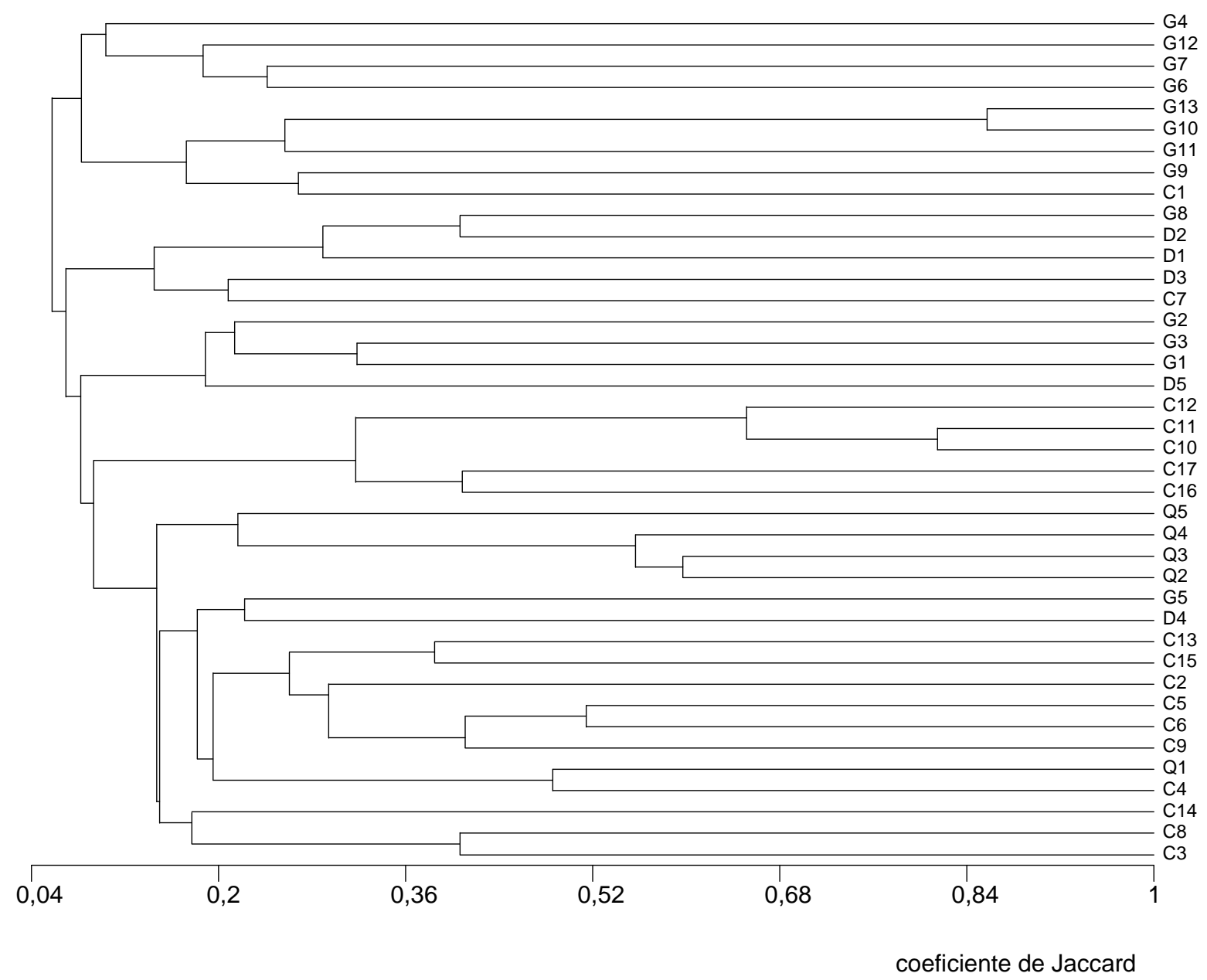

Figura 6 - Dendrograma elaborado a partir da matriz binária de 217 gêneros botânicos em 40 habitats em afloramentos rochosos no Brasil, utilizando-se o índice de similaridade de Jaccard e UPGMA (para abreviatura das localidades ver Anexo). 


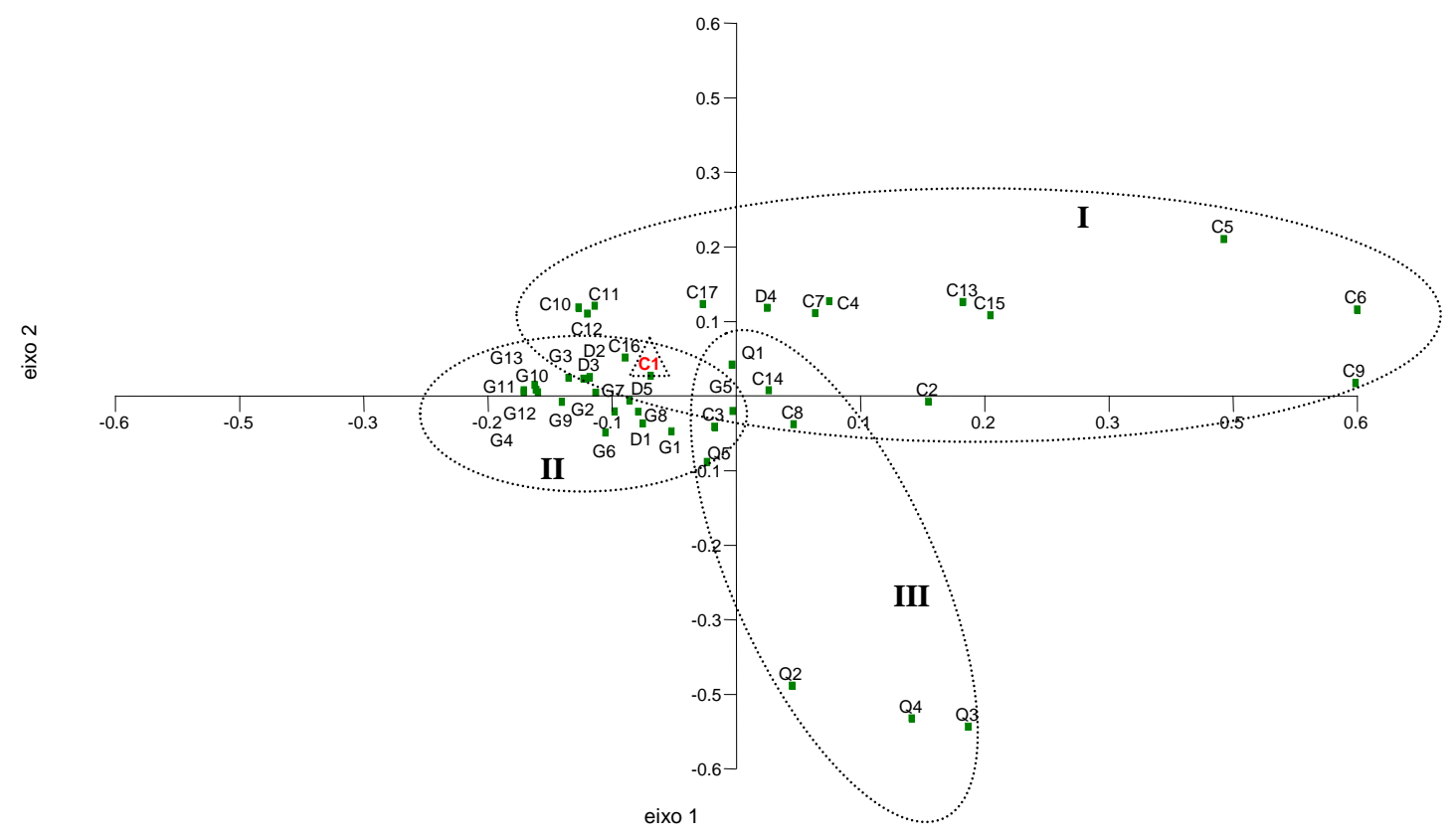

Figura 7 - Interpolação dos eixos 1 e 2 resultantes da análise de PCO aplicada à matriz de 217 gêneros botânicos presentes em 40 habitats em afloramentos rochosos do Brasil (para abreviatura das localidades ver Anexo). As elipses agrupam as localidades segundo a litologia dominante, onde I=cangas, II=granitognaisses, III=quartzito-arenitos, enquanto o triângulo destaca as cangas de Corumbá.

A análise de correspondência (DCA) aplicada para os gêneros e localidades mostrou que $16 \%$ do conteúdo total de informação da matriz foi explicado pelos primeiros vetores de escores no arranjo das relações entre as localidades, sendo 9,3\% e 6,9\% da variação dos dados no primeiro e segundo eixos, respectivamente.

A interpolação dos dois primeiros eixos da análise de ordenação ressaltou o fato de haver aí uma associação entre a litologia predominante e a flora em nível genérico, o que já era esperado. De um lado do gradiente ficaram as comunidades 
de afloramentos granítico-gnáissicos em contraposição às cangas, no primeiro eixo da DCA. Entre as comunidades de granito-gnaisses distinguiram-se aquelas sob clima mais quente daquelas sob climas mais frios e úmidos. As correlações de Pearson sugerem que a configuração deste gradiente seja determinada pelas presenças de Bernardia e Enteropogon $(\mathrm{r}=0,5472)$ e Corchorus $(\mathrm{r}=0,5368)$, em contraposição com a dos gêneros Byrsonima $(\mathrm{r}=-0,6609)$ e Xylopia $(\mathrm{r}=-0,6558)$. Os afloramentos de quartzito-arenitos distinguiram-se dos demais agrupando-se no lado inferior do eixo 2 (Figura 8).

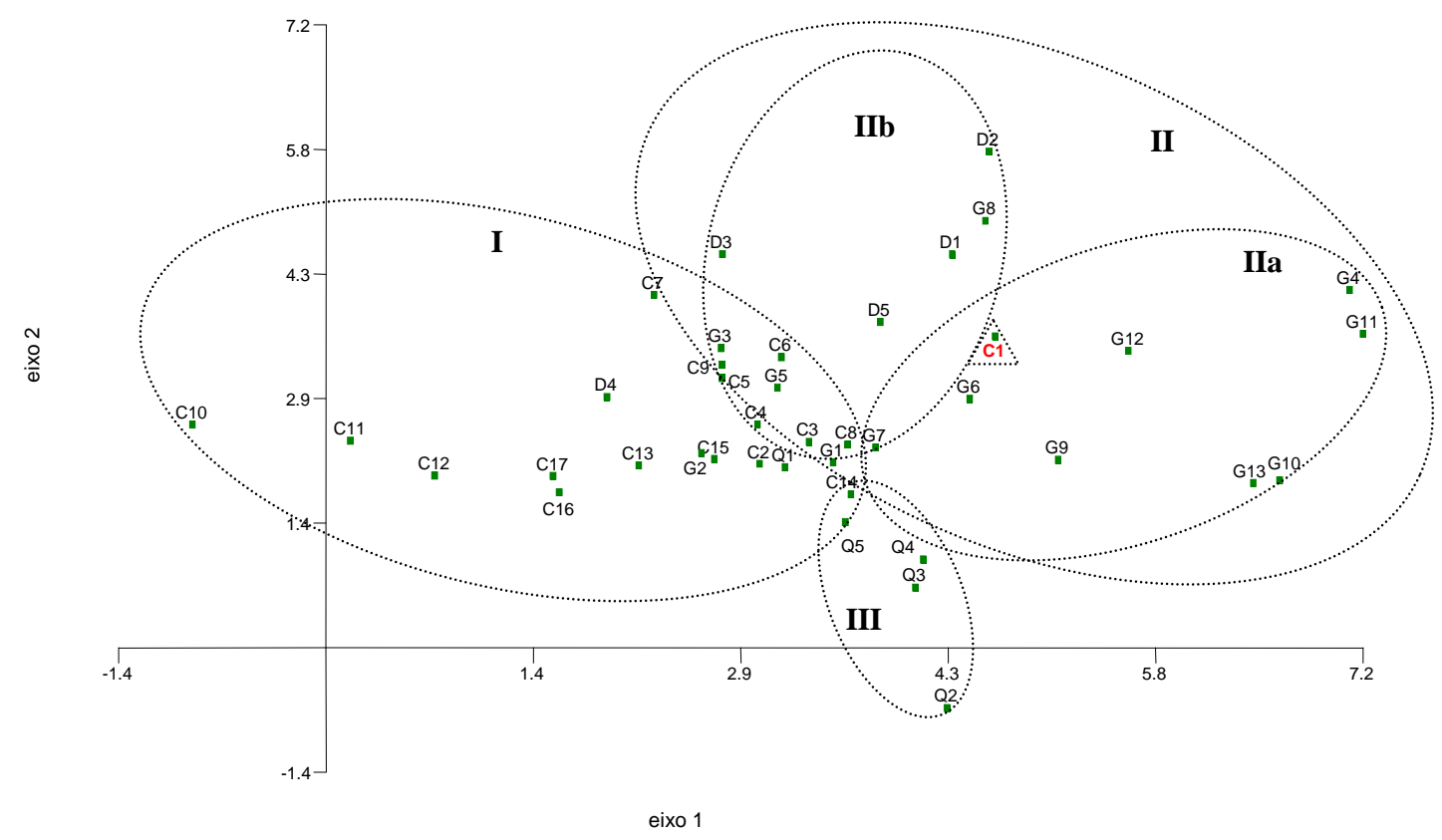

Figura 8 - Interpolação dos eixos 1 e 2 resultantes da análise de DCA aplicada à matriz de 217 gêneros botânicos presentes em 40 habitats em afloramentos rochosos do Brasil (para abreviatura das localidades ver Anexo). As elipses agrupam as localidades segundo a litologia dominante, onde I=cangas, II=granitognaisses, IIa=locais com temperaturas mais elevadas, IIb=locais com temperaturas mais baixas, III=quartzito-arenitos, enquanto o triângulo destaca as cangas de Corumbá. 


\section{Discussão}

\section{Análise florística}

Nas análises, as famílias Poaceae, Asteraceae, Orchidaceae, Fabaceae e Cyperaceae predominaram nos 40 habitats em afloramentos rochosos do Brasil. Tais famílias apresentam distribuição cosmopolita e grande número de espécies, onde Poaceae é apontada como uma das famílias com maior riqueza específica em afloramentos rochosos tropicais (Ibish et al. 1995).

Os gêneros com maior número de ocorrências foram Axonopus, Andropogon, Baccharis, Tillandsia, Tibouchina e Mellinis. As espécies dos gêneros Axonopus e Andropogon utilizadas nas análises têm distribuição ampla, muitas delas desde o México até o Brasil (Rocha \& Secco 2004, Zanin \& Longhi-Wagner 2006), enquanto as espécies de Baccharis e Tibouchina são exclusivas do Brasil (Meyer 2008, Schneider et al. 2009). Na matriz utilizada, Tillandsia responde por metade das espécies de Bromeliaceae (8/16) epífitas-epíliticas. A importância desta família em afloramentos rochosos nos neotrópicos foi destacada por Ibisch et al. (1995): o gênero Tillandsia possui diversos elementos com metabolismo CAM, o que explicaria o estabelecimento destas espécies em ambientes xéricos (Crayn et al. 2004). O gênero Mellinis é representado por espécies exóticas invasoras que conseguem se estabelecer nos afloramentos rochosos no sudeste do Brasil (Porembski 2000) e, como mostraram nossos resultados, parecem estar se disseminando pelos diferentes afloramentos rochosos. A colonização e 
estabelecimento de Mellinis minutiflora em áreas abertas de cerrado podem provocar um efeito de exclusão de gramíneas nativas (Pivello et al. 1999), o que poderia acontecer em certo grau nos afloramentos rochosos.

Dentre estas famílias, Porembski (2007) destaca que cerca de 30\% das espécies de Poaceae, Cyperaceae e Fabaceae ocorrem preferencialmente em afloramentos rochosos. Certas características morfológicas ou fisiológicas, como a absorção de umidade atmosférica, a poiquilohidria, além de suculência (Porembski et al. 1997b), permitiriam que vários elementos destas famílias sobrevivam sob condições ambientais inóspitas dos afloramentos rochosos. Além disso, várias espécies de Poaceae e Cyperaceae ocorrem como plantas efêmeras concentradas na base das vertentes onde se acumula uma fina camada de solo que, por sua vez, permite que a água escorra continuamente durante a estação chuvosa (Porembski et al. 1997).

\section{Similaridade florística dos afloramentos rochosos}

Em todos os níveis hierárquicos avaliados, a composição florística das cangas sul-mato-grossenses apresentou-se mais similar à dos afloramentos rochosos do Nordeste do Brasil (Caruaru, Petrolândia e Quixadá), apesar de o Pantanal se inserir na área core do cerrado no Centro-Oeste brasileiro. Alguns estudos sobre a vegetação da mata seca calcária nos arredores de Corumbá já a haviam comparado à caatinga, devido à semelhança fisionômica na estação seca, com a completa perda de folhas das espécies da mata e a presença de cactáceas e barrigudas. Ratter et al. (1988) citaram várias espécies e gêneros comuns entre a 
Caatinga nordestina e a vegetação das matas deciduais sobre calcário nas proximidades da cidade de Corumbá, inferindo que a distribuição disjunta destes táxons seria reflexo de uma expansão deste tipo de vegetação durante os longos períodos secos do Terciário. Nossos resultados corroboram a proposta de Prado \& Gibbs (1993), Pennington et al. (2000, 2004) e Spichiger et al. (2004) para a distribuição de espécies arbóreas típicas de habitats xéricos, formando um arco seco por florestas sazonalmente secas desde a Caatinga nordestina, passando pelo Centro-Oeste brasileiro até os vales secos da Bolívia e Argentina, acrescentando que a semelhança entre a flora da Caatinga e das cangas de Corumbá também pode se estender para os componentes herbáceos que ocorrem nos afloramentos rochosos.

As análises de cluster para as matrizes de famílias e gêneros indicaram uma segregação daquela vegetação presente em granito-gnaisses em relação àquela existente sobre as cangas, cabendo observar o fato de as comunidades dos quartzito-arenitos apresentarem-se floristicamente associadas às comunidades de cangas. De modo geral, o que se notou foi que os afloramentos graníticos formaram dois grupos: um constituído pelas comunidades do Nordeste brasileiro, sob clima geralmente mais quente, e outro formado pela vegetação de afloramentos do Sul do Brasil e dos campos de altitude (Itaitaia e Serra do Brigadeiro), sob clima aparentemente mais frio e úmido. Analisando a similaridade entre diferentes ambientes áridos da América do Sul, Sarmiento (1975) verificou que não existe uma única flora xérica para todo o continente, mas que ela se distingue em três grupos: tropical, frio e temperado. A vegetação das 
cangas de Carajás apresentou maior similaridade com a flora de Minas Gerais e as comunidades dos quartzito-arenitos da Chapada Diamantina estiveram mais associados às cangas de Minas Gerais.

Quanto às comunidades vegetais estabelecidas sobre quartzito-arenitos, verificou-se que os afloramentos rochosos da Chapada Diamantina formaram um grupo homogêneo, mas a comunidade estudada por Vincent \& Meguro (2008) na Serra do Rola Moça apresentou-se, em todos os níveis hierárquicos, mais similar às cangas de Minas Gerais do que com demais afloramentos quartzíticos. Esta baixa similaridade entre a flora da porção mineira da Cadeia do Espinhaço, inserida no bioma cerrado, e a da porção baiana, inserida no bioma caatinga, vem sendo observada para diversos táxons (p.ex. Harley 1988, Rapini et al. 2002, Azevedo \& van den Berg 2007).

\section{Análises de ordenação}

As análises de correlação entre localidades, famílias botânicas e o primeiro eixo da PCO revelaram que táxons que contribuíram para a segregação entre os sítios de cangas e quartzito-arenitos dos sítios de granito-gnaisses foram aquelas notadamente cosmopolitas ou de ampla distribuição. Os componentes arbustivos e herbáceos das famílias Fabaceae e Rubiaceae foram registrados para cangas e quartzito-arenitos, e elementos da família Verbenaceae para as cangas de Minas Gerais, estando todas as três ausentes nos afloramentos graníticos em contraposição aos elementos de Aristolochiaceae registrados somente para os afloramentos em Petrolândia e Feira de Santana. As famílias Fabaceae e Rubiaceae 
ocorrem em quase todas as formações vegetais no Brasil, sendo que a última é um componente importante nos campos rupestres (Giulietti \& Pirani 1988).

As espécies de Fabaceae analisadas neste trabalho, têm uma distribuição mais ampla, com dois táxons da África e Américas (Desmodium barbatum e Zornia latifolia), 5 distribuídos pelas Américas, sete restritos à América do Sul e 8 ao Brasil. Já as espécies de Rubiaceae avaliadas estiveram restritas às Américas: dois táxons nas Américas, quatro na America Central e do Sul, quatro na América do Sul e apenas dois restritos ao Brasil. A família Verbenaceae contou com cinco espécies restritas ao Brasil, uma restrita às Américas e uma espécie com ampla distribuição (cosmopolita), enquanto Aristolochiaceae teve uma espécie com distribuição no Nordeste do Brasil e no Peru.

As análises de correlação entre localidades, famílias botânicas e o primeiro eixo da DCA destacaram a segregação dos sítios de cangas daqueles de granitos, devido à ocorrência de elementos de Malpighiaceae. As cangas de Carajás se distinguiram das cangas de Minas Gerais pela ocorrência de Annonaceae, ao passo que os quartzito-arenitos contaram com componentes de Rubiaceae. As espécies de Malpighiaceae analisadas aqui foram neotropicais: com uma espécie ocorrendo na América Central até a do Sul, outra bem distribuída pelo Brasil além de ocorrência na Bolívia, cinco espécies registradas para o sudeste da América do Sul e apenas uma foi restrita ao Brasil. Entre as espécies de Annonaceae analisadas, uma delas se distribui da América Central até a do Sul e a outra ocorre na Venezuela e na região amazônica. 
As análises de correlação entre os gêneros, localidades e o primeiro eixo da PCO apresentaram uma segregação entre as cangas em Minas Gerais, devido à presença de espécies dos gêneros Habranthus e Galactia, mais os sítios de quartzitoarenitos, polarizando com os afloramentos graníticos da Bahia, Pernambuco e Ceará, pela ocorrência do gênero Encholirium nestes. Para compreender a configuração deste gradiente ambiental, analisamos a distribuição das espécies deste gêneros como segue. A distribuição de Habranthus irwinianus restringe-se à região sul da Cadeia do Espinhaço, próximo a Belo Horizonte, com disjunções na Serra da Canastra e Ibitipoca (Oliveira 2006). Galactia martii ocorre no Paraguai e na região sul, sudeste do Brasil, e também em Goiás e na Bahia, preferencialmente em ambientes de cerrado e campos (Felfili et al. 2007). Eriope exaltata ocorre somente na Bahia e Eriope macrostachya ocorre em áreas montanhosas do sul da Bahia, estendendo-se do Paraná até o Paraguai, assim como na área de caatinga de Pernambuco (Almeida \& Albuquerque 2002). Encholirium spectabile é uma espécie frequente em afloramentos rochosos da Caatinga com limite sul na região de Milagres, na Bahia (Forzza 2005).

As análises de correlação entre os gêneros, localidades e o primeiro eixo da DCA revelaram a segregação entre os afloramentos de granitos do nordeste e os afloramentos do sul do país mais Itatiaia, assim como segregação destes com os afloramentos de cangas e de quartzito-arenitos. Os gêneros que contribuíram para esta configuração foram: Bernardia, Enteropogon e Corchorus, em afloramentos rochosos de Pernambuco (Caruaru e Petrolândia). A distribuição das espécies de Corchorus é bastante ampla pelas Américas, desde o EUA e México até a América 
do Sul, enquanto as espécies de Bernardia e Enteropogon ocorrem da América

Central e, na América do Sul, até o Nordeste Brasileiro. As espécies dos gêneros Byrsonima e Xylopia também ocorrem desde a América Central até a um limite mais ao centro-sul da América do Sul, alcançando até os cerrados do Brasil, além da Bolívia e Paraguai.

\section{Características ambientais dos afloramentos rochosos}

A similaridade florística entre os diversos afloramentos rochosos no Brasil é melhor compreendida como resultado da relação entre, de um lado, as condições climáticas a que os mesmos estão sujeitos e, de outro, as peculiaridades geológicas, geomorfológicas, paleoclimáticas e históricas que incidiram no estabelecimento da flora de cada local.

Inicialmente, este trabalho partiu do pressuposto de que as condições geológicas da rocha matriz sobre a qual estas comunidades vegetais se estabeleceram seriam suficientes para explicar as relações florísticas entre os diferentes afloramentos, já que a planta se assenta sobre um delgado substrato. Assim, apenas nas ilhas de solo haveria algum tipo de tamponamento capaz de prover o estabelecimento e a manutenção de espécies mais exigentes.

Os padrões de segregação entre os sítios visíveis nas análises exploratórias empregadas parecem ser mais ou menos coerentes com a natureza do substrato, especialmente a relacionada com sua mineralogia. Neste sentido pode-se evocar a alta influência exercida pela rocha, dada a ausência e/ou pequena profundidade 
do solo, o que implica na interação direta entre a planta e o mineral, sem as alterações do intemperismo químico e da biota.

Os afloramentos rochosos da África têm sido amplamente estudados, sendo relatada a ocorrência de alguns táxons em função do tipo de substrato (Porembski et al. 1994). Além disso, pode-se presumir uma grande importância de atributos físicos como a permeabilidade da rocha e a rugosidade da superfície, associados tanto à composição mineralógica quanto a variações em pequena escala, como a textura e tamanho dos cristais. Assim, mecanismos de tolerância a metais pesados, grandes amplitudes térmicas diárias e pouca água disponível definiriam certa uniformidade à composição florística destes habitats. Esta relação estreita entre flora e condições mineralógicas é bastante explorada nos países de clima temperado ao utilizarem plantas como bioindicadores de reservas de minério (Ginocchio \& Baker 2004, Baker \& Brooks 1988).

Broadley et al. (2001) investigaram a influência da filogenia na capacidade das plantas de acumular metais pesados $(\mathrm{Cd}, \mathrm{Cr}, \mathrm{Cu}, \mathrm{Ni}, \mathrm{Pb}, \mathrm{Zn})$ em suas raízes, ao compilarem dados publicados em 44 estudos. Obtiveram resultados bastante interessantes ao constatar que as ordens com maior número de táxons hiperacumuladores de metais pesados foram Malpighiales e Brassicales, seguidas por Asterales, Lamiales, Caryophyllales, Poales, Gentianales, Malvales, Fabales, Ericales e Solanales. Apesar de os trabalhos compilados nesta revisão apresentarem poucos gêneros ou espécies em comum com os avaliados aqui, as principais famílias de espécies em afloramentos rochosos no Brasil pertencem a estas ordens, sendo uma interessante linha de investigação para estudos futuros. 
Entre as espécies hiperacumuladoras ou tolerantes a metais pesados listadas para a América Latina (Ginocchio \& Baker 2004) observaram-se 16 gêneros em comum com o presente trabalho (4,2\% do total de gêneros).

Os resultados de agrupamento e ordenação, em ambos os níveis taxonômicos, revelaram a segregação entre sítios de granitos e de cangas. Os afloramentos rochosos, predominantemente granítico-gnáissicos, da região nordeste do Brasil, Serra do Mar e Sul do Brasil, assim como as Morrarias do Urucum em Mato Grosso do Sul, são constituídos por rochas do embasamento cristalino, ígneas e metamórficas pré-cambrianas (Suguio 2005), que sofreram diversos eventos tectônicos atuantes sobre a plataforma sul-americana (Bigarella et al. 2007), saliências orográficas com relevos de características serranas e planálticas fortemente escarpadas (Saadi et al. 2005). Estes afloramentos rochosos, na maioria dos casos, afiguram-se como estruturas dômicas com vertentes bastante convexas e de declividade acentuada, com um efeito importante nas comunidades rupícolas.

Os afloramentos ferruginosos correspondem a rochas paleozóicasmesozóicas (Suguio 2005) e os afloramentos da Cadeia do Espinhaço, que englobam tanto cangas quanto quartzito-arenitos, fazem parte do Cráton São Francisco, com predomínio de rochas arqueanas (Saadi et al. 2005). Já os afloramentos ferríferos da Serra dos Carajás encontram-se nos topos de montanhas com altitude de cerca de 900 m (Morais \& Pereira Junior 2009), intercalados com rochas basálticas, cortados por diversos sills e diques, de idade arqueana (Lindenmayer et al 2001), com o predomínio de paisagens planas ou suavemente onduladas nos planaltos (Saadi et al. 2005). 
Diferentemente das formações dômicas de granito-gnaisse, as cangas e quartzito-arenito mostram-se como estruturas planas, pelo menos por certa extensão, o que influencia o estabelecimento das comunidades rupícolas diversas. Outra característica distinta nos platôs das cangas de Carajás e de Minas Gerais é a ocorrência de cavernas, descritas como formas pseudocársticas localizadas nas bordas dos platôs, associada ao rebaixamento do nível de base resultante do tectonismo epirogenético durante o Terciário superior e/ou Quaternário (Lindenmayer et al. 2001).

As rochas sedimentares da Bacia do Espinhaço estão localizadas em dois domínios fisiográficos: Serra do Espinhaço e Chapada Diamantina e têm sido incluídas no Supergrupo Espinhaço (Danderfer \& Dardenne 2002).

Grosso modo, pode-se evocar certa coincidência entre a vegetação dos afloramentos rochosos e os padrões gerais para os compartimentos geológicos e geomorfológicos do Brasil mas ainda é necessário um maior volume de informações sobre estas vegetações xéricas para buscarmos compreender como se dá tais relações florísticas. 


\section{Considerações finais}

A vegetação dos afloramentos rochosos no Brasil deve sua singularidade, tanto em nível de famílias quanto de gêneros, ao tipo de litologia dominante, com algumas exceções que serão relatadas posteriormente.

A vegetação sobre as cangas teve gradientes longos nas análises exploratórias, possivelmente devido à sua própria heterogeneidade (afora o pequeno volume de estudos relativos às comunidades de Carajás e de Mato Grosso do Sul).

Entre as localidades de afloramentos do escudo cristalino, dois subgrupos chamaram a atenção, um formado pelas comunidades do Nordeste brasileiro, do Rio de Janeiro e de Corumbá, e outro com a vegetação do Sul do Brasil, Itatiaia e Serra do Brigadeiro. A interação entre os fatores limitantes comuns aos vários afloramentos, condicionados pela escassez de solo, e variáveis do clima, como as temperaturas máximas e mínimas ou altitude, por exemplo, podem representar restrições a diferentes grupos de plantas.

O primeiro subgrupo está sujeito a temperaturas mais elevadas e a um regime de precipitação variado, desde o clima semi-árido com precipitações baixas, irregulares e concentradas (Nordeste), a um clima com uma estação seca bem definida (Corumbá) até precipitações abundantes (Rio de Janeiro).

Já o segundo subgrupo foi constituído por localidades do Sul do país com diferentes litologias (basaltos, granitos e arenitos) e pelos campos de altitude 
(granitos e nefeline-sienito), todos os locais submetidos a um clima subtropical úmido, sem estação seca e precipitação bem distribuída ao longo do ano. A vegetação nestes afloramentos rochosos não computou componentes das famílias Fabaceae e Bignoniaceae, sendo esta uma característica que contribuiu para agrupá-los, já que há uma tendência em reduzir o número de espécies arbóreas destas famílias com o aumento da latitude e altitude (Smith et al. 2004). Estas comunidades apresentaram maior similaridade florística entre si e isto poderia estar relacionado à conexão entre a vegetação de campos de altitude do Brasil, locais de clima temperado do Sudeste brasileiro e a região sudeste dos Andes. Tal conexão foi proposta por Safford (2007) ao sugerir que os campos de altitude do Sudeste do Brasil atuariam como ilhas de clima temperado no interior da floresta tropical atlântica, o que seria reforçada por alguns registros palinológicos para a região Sul e Sudeste do Brasil indicando que, entre 48 mil e 14 mil anos A.P., a paisagem foi dominada por vegetações de campos, com clima mais frio e seco que o atual, e estas condições se estenderam até o início do Holoceno, quando o aumento de temperatura restringiu a distribuição de Podocarpus para locais de maiores latitudes ou altitudes, como as Chapadas do Distrito Federal (Oliveira et al. 2005).

As análises de agrupamento e ordenação para comunidades vegetais que se estabelecem sobre afloramentos rochosos no Brasil permitiram distinguir as localidades em função da litologia e, secundariamente, pelo clima, em nível de família e de gênero. Os resultados separaram localidades de afloramentos de granito-gnaissses das cangas e dos quartzito-arenito. Os afloramentos de granito- 
gnaisses se dividiram em dois subgrupos, um com temperaturas mais elevadas (Nordeste, Rio de Janeiro e Corumbá), e outro grupo com temperaturas aparentemente mais baixas e ausência de estação seca (Rio Grande do Sul, Itatiaia e Serra do Brigadeiro).

As cangas apresentaram maior heterogeneidade, visto terem as cangas de Corumbá composição florística mais semelhante à dos granitos do Nordeste e do Rio de Janeiro. Entretanto, as cangas de Carajás possuem maior similaridade florística com as cangas de Minas Gerais. Já os quartzito-arenitos foram mais semelhantes às cangas de Minas Gerais, ambas localizadas em platôs no alto das Serras. A relação florística entre as cangas de Corumbá e a caatinga brasileira corrobora a hipótese de uma ligação pretérita entre a vegetação xérica que estenderia-se desde a Caatinga brasileira, passando pelo Centro-Oeste e chegando até os vales secos da Bolívia e Argentina, devendo ser explorada em estudos posteriores.

De qualquer modo, este trabalho mostrou que as relações florísticas das comunidades nos afloramentos avaliados podem ser resultantes de condições peculiares propiciadas pela litologia predominante e, secundariamente, pelas condições climáticas. Entretanto, ressalta-se a necessidade de um maior volume de informações sobre estas comunidades vegetais para uma melhor compreensão de suas relações atuais com o substrato e clima, além de informações sobre as relações filogenéticas que possam refletir relações biogeográficas. 


\section{Referências bibliográficas}

ALMEIDA, C.F.C.B.R. \& ALBUQUERQUE, U.P. 2002. Check-list of the family Lamiaceae in Pernambuco, Brazil. Brazilian Archives of Biology and Technology, v.45, n.3, p.343-353, set.

ANJOS, E.C. \& OKIDA, R. 2000. Geologia. In Zoneamento ambiental da Borda Oeste do Pantanal: Maciço do Urucum e Adjacências (J.S.V. Silva, ed.). Embrapa, Brasília, p.23-46.

APG. 2003. An update of the Angiosperm Phylogeny Group classification for the orders and families of flowering plants: APG II. Botanical Journal of the Linnean Society 141:399-436.

ARAÚJO, F.S.; OLIVEIRA, R.F. \& LIMA-VERDE, L.W. 2008. Composição, espectro biológico e síndromes de dispersão da vegetação de um inselbergue no domínio da caatinga, Ceará. Rodriguésia, v.59,n.4, p.659-671.

AZEVEDO, C.O. \& VAN DEN BERG, C. 2007. Análise comparativa de áreas de campo rupestre da Cadeia do Espinhaço (Bahia e Minas Gerais, Brasil) baseadas em espécies de Orchidaceae. Sitientibus série Ciências Biológicas, v.7, n.3, jul.set., p.199-210

BAKER, A.J.M. \& BROOKS, R.R. 1988. Botanical exploration for minerals in the humid tropics. Journal of Biogeography, v.15, p.221-229. 
BARTHLOTT, W., GROGER, A. \& POREMBSKI, S. 1993b. Some remarks on the vegetation of tropical inselbergs: diversity and ecological differentiation. Biogéographica 69(3):17-36.

BARTHLOTT, W.; POREMBSKI, S.; SZARZYNSKI, J. \& MUND, J.P. $1993 a$. Phytogeography and vegetation of tropical inselbergs. Actes du colloque international de Phytogéographie tropicale. Paris, jun. p.15-24.

BAUER, D. \& LAROCCA, J. 2003. Flora vascular rupestre de um afloramento basáltico na localidade de Fazenda Padre Eterno, RS. Pesquisas Botânica 53:101119.

BIGARELLA, J.J.; BECKER, R.D. \& SANTOS, G.F. 2007. Estrutura e origem das paisagens tropicais e subtropicais. Vol.1. 2.ed. Florianópolis, SC: Editora da UFSC. $425 p$.

BRANDÃO, M. \& GAVILANES, M.L. 1990. Mais uma contribuição para o conhecimento da Cadeia do Espinhaço em Minas Gerais (Serra da Piedade) - II. Daphne 1(1):26-43.

BRANDÃO, M. 1992. Caracterização geomorfológica, climática, florística e faunística da Serra do Curral em Belo Horizonte, MG. Daphne 2(2):13-38.

BRANDÃO, M., GAVILANES, M.L., LACA-BUENDIA, J.P., CUNHA, L.H.S. \& MACEDO, J.F. 1989. Flora da Serra de Itabirito, Minas Gerais - primeira contribuição. Acta botanica brasilica 3(2):237-251, supl.

BRASIL. 1982. Projeto RADAMBRASIL. Folha SE. 21 Corumbá e parte da folha SE. 20. (Levantamento de recursos naturais, 27). MME, Rio de Janeiro. 
BROADLEY, M.R.; WILLEY, N.J.; WILKINS, J.C.; BAKER, A.J.M.; MEAD, A. \& WHITE, P.J. 2001. Phylogenetic variation in heavy metal accumulation in angiosperms. New Phytologist, v.152, p.9-27

BRUMMITT, R.K. \& POWELL, C.E. 1992. Authors of plant names. Royal Botanical Gardens, Kew, 732p.

BURBANCK, M.P. \& PLATT, R.B. 1964. Granite outcrop communities of the piedmont plateau in Georgia. Ecology 45(2):292-306.

CAIAFA, A.N. \& SILVA, A.F. 2005. Composição florística e espectro biológico de um campo de altitude no Parque Estadual da Serra do Brigadeiro, Minas Gerais, Brasil. Rodriguésia 56(87):163-173

CAIAFA, A.N. \& SILVA, A.F. 2007. Structural analysis of the vegetation on a highland granitic rock outcrop in Southeast Brazil. Revista Brasileira de Botânica 30(4):657-664.

CARAUTA, J.P.P. \& OLIVEIRA, R.R. 1984. Plantas vasculares dos morros da Urca, Pão de Açúcar e Cara de Cão. Rodriguésia 36(59):13-24.

CARDOSO, E.L., OLIVEIRA, H., AMARAL, J.A.M., KER, J.C., PEREIRA, N.R., SANTOS, R.D., TÔSTO, S.G., SPERA, S.T. \& CARVALHO JÚNIOR, W. 2000. Pedologia. In Zoneamento ambiental da borda oeste do Pantanal: maciço do Urucum e adjacências (J.S.V. Silva, org.). Brasília, DF, Embrapa Comunicação para Transferência de Tecnologia, p.95-109. 
CONCEIÇÃO, A.A. \& GIULIETTI, A.M. 2002. Composição florística e aspectos estruturais de campo rupestre em dois platôs do Morro do Pai Inácio, Chapada Diamantina, Bahia, Brasil. Hoehnea 29(1): 37-48

CONCEIÇÃO, A.A. \& PIRANI, J.R. 2005. Delimitação de habitats em campos rupestres na Chapada Diamantina, Bahia: substratos, composição florística e aspectos estruturais. Boletim de Botânica da Universidade de São Paulo 23(1):85111.

CONCEIÇÃO, A.A.; GIULIETTI, A.M. \& MEIRELLES, S.T. 2007a. Ilhas de vegetação em afloramentos de quartzito-arenito no Morro do Pai Inácio, Chapada Diamantina, Bahia, Brasil. Acta Botanica Brasilica v.21, n.2, p.335-347

CONCEIÇÃO, A.A.; PIRANI, J.R. \& MEIRELLES, S.T. 2007b. Floristics, structure and soil of insular vegetation in four quartzite-sandstone outcrops of "Chapada Diamantina", northeast Brazil. Revista Brasileira de Botânica v.30, n.4, p.641-656, out.-dez.

CRAYN, D.M.; WINTER, K. \& SMITH, J.A.C. 2004. Multiple origins of crassulacean acid metabolism and the epiphytic habit in the neotropical family Bromeliaceae. PNAS v.101, n.10, p.3703-3708, mar.

CUEVAS, C.N.R. \& MANZANARES, A.R. 1993. Primer registro de Corchorus hirtus L. (Tiliaceae) en Cuba. Acta Botánica Mexicana, v.21, p.23-26, abr.

DANDERFER, A. \& DARDENNE, M.A. 2002. Tectonoestratigrafia da Bacia Espinhaço na porção centro-norte do Cráton do São Francisco: registro de uma 
evolução poliistórica descontínua. Revista Brasileira de Geociências, v.32, n.4, p.449-460, dez.

FELFILI, J.M.; NASCIMENTO,A.R.T.; FAGG, C.W. \& MEIRELLES, E.M. 2007. Floristic composition and community structure of a seasonally deciduous forest on limestone outcrops in Central Brazil. Revista Brasileira de Botânica v.30, n.4, p. 611-621, out.-dez.

FERNANDES, I. \& BAPTISTA, L.R.M. 1988. Levantamento da flora vascular rupestre do Morro Sapucaia e Morro do Cabrito, Rio Grande do Sul. Acta botanica brasilica 1(2):95-102, supl.

FERNANDES, I. \& BAPTISTA, L.R.M. 1999. Inventário da flora rupestre e pararupestre de "Casa de Pedra", Bagé, Rio Grande do Sul. Pesquisas Botânica 49:5370.

FORZZA, R.C. 2005. Revisão taxonômica de Encholirium Mart. ex Schult. \& Schult. f. (Pitcairnioideae - Bromeliaceae). Boletim de Botânica da Universidade de São Paulo v.23, n.1, p. 1-49

FRANÇA, F., MELO, E. \& SANTOS, C.C. 1997. Flora de inselbergs da região de Milagres, Bahia, Brasil: I. Caracterização da vegetação e lista de espécies de dois inselbergs. Sitientibus 17:163-184.

FRANÇA, F., MELO, E., SANTOS, A.K.A., MELO, J.G.A.N., MARQUES, M., SILVA-FILHO, M.F.B., MORAES, L. \& MACHADO, C. 2005. Estudos ecológico e florístico em ilhas de vegetação de um inselberg no semi-árido da Bahia, Brasil. Hoehnea 32(1):93-101. 
FRANÇA, F.; MELO, E. \& GONÇALVES, J.M. 2006. Aspectos da diversidade da vegetação no topo de um inselbergue no semi-árido da Bahia, Brasil. Sitientibus, série Ciências Biológicas, v.6, n.1, p.30-35

GAVILANES, M.L. \& BRANDÃO, M. 1991. Flórula da Reserva Biológica Municipal do Poço Bonito, Lavras - MG. II - Formação campo rupestre. Daphne 2(1):5-7.

GINOCCHIO, R. \& BAKER, A.J.M. 2004. Metallophytes in Latin America: a remarkable biological and genetic resource scarcely known and studied in the region. Revista Chilena de Historia Natural v.77, p.185-194.

GIULIETTI, A.M. \& PIRANI, J.R. 1988. Patterns of geographic distribution of some plant species from the Espinhaço Range, Minas Gerais and Bahia, Brazil. In Proceedings of a workshop on neotropical distribution patterns (P.E. Vanzolini \& W.R. Heyer, orgs.). Academia Brasileira de Ciências, Rio de Janeiro, p.39-69.

GIULIETTI, A.M., MENEZES, N.L., PIRANI, J.R., MEGURO, M. \& WANDERLEY, M.G.L. 1987. Flora da Serra do Cipó, Minas Gerais: caracterização e lista das espécies. Boletim de Botânica da Universidade de São Paulo 9:1-151.

GOMES, P. \& ALVES, M. 2009. Floristic and vegetation aspects of an inselberg in the semi-arid region of Northeast Brazil. Edinburgh Journal of Botany, v.66, n.2, p.329-346.

HAMBLER, D.J. 1964. The vegetation of granitic outcrops in western Nigeria. Journal of Ecology v.52, p.573-594 
HARALYI, N.L.E. \& WALDE, D.H.G. 1986. Os minérios de ferro e manganês da região de Urucum, Corumbá, Mato Grosso do Sul. In Principais depósitos minerais do Brasil. Vol. II (C. Schobbenhans \& C.E.S. Coelho, eds.). DNPM, Brasília, p.122-144.

HARLEY 1988. Evolution and distribution of Eriope (Labiatae) and its relatives in Brazil. In Proceedings of a workshop on neotropical distribution patterns (P.E. Vanzolini \& W.R. Heyer, orgs.). Academia Brasileira de Ciências, Rio de Janeiro, p.71-120.

IBISCH, P.L., RAUER, G., RUDOLPH, D. \& BARTHLOTT, W. 1995. Floristic, biogeographical, and vegetational aspects of Pre-Cambrian rock outcrops (inselbergs) in eastern Bolivia. Flora 190:299-314.

JACOBI, C.M., CARMO, F.F., VINCENT, R.C. \& STEHMANN, J.R. 2007. Plant communities on ironstone outcrops: a diverse and endangered Brazilian ecosystem. Biodiversity and Conservation 16:2185-2200.

JACOBI, C.M.; CARMO, F.F. \& VINCENT, R.C. 2008. Estudo fitossociológico de uma comunidade vegetal sobre canga como subsídio para a reabilitação de áreas mineradas no Quadrilátero Ferrífero, MG. Revista Árvore v.32, n.2, p.345-353

LINDENMAYER, Z.G.; LAUX, J.H. \& TEIXEIRA, J.B.G. 2001. Considerações sobre a origem das formações ferríferas da Formação Carajás, Serra dos Carajás. Revista Brasileira de Geociências, v.31, n.1, p.21-28, Mar.

MAIO, C.R. 1987. Geomorfologia do Brasil: fotos e comentários. Fundação Instituto Brasileiro de Geografia e Estatítica - IBGE, Rio de Janeiro, 3.ed. 
MEDINA, B.M.O., RIBEIRO, K.T. \& SCARANO, F.R. 2006. Plant-plant and planttopography interactions on a rock outcrop at high altitude in southeastern Brazil. Biotropica 38(1):27-34.

MEIRELLES, S.T., PIVELLO, V.R. \& JOLY, C.A. 1999. The vegetation of granite rock outcrops in Rio de Janeiro, Brazil, na the need for its protection. Environmental Conservation 26(1):10-20.

MEYER, F.S. 2008. O gênero Tibouchina Aubl. (Melastomataceae) no estado do Paraná, Brasil. Curitiba, PR: Universidade Federal do Paraná (dissertação de Mestrado ao programa de pós-graduação em Botânica)

MORAIS, M.C. \& PEREIRA JUNIOR, P.M. 2009. Informações geoambientais derivadas de imagens de radar (R99B/SIPAM) e ópticas (LANDSAT/TM5) em jazimento de minério de ferro em Carajás. REM: R.Esc.Minas, Ouro Preto, v.62, n.2, p.131-137, abr.-jun.

MOURÃO, A. \& STEHMANN, J.R. 2007. Levantamento da flora do campo rupestre sobre canga hematítica couraçada remanescente na Mina do Brucutu, Barão de Cocais, Minas Gerais, Brasil. Rodriguésia 58(4):775-786.

NEVES, S.P.S. \& CONCEIÇÃO, A.A. 2007. Vegetação em afloramentos rochosos na Serra do Sincorá, Chapada Diamantina, Bahia, Brasil. Sitientibus série Ciências Biológicas v.7, n.1, jan.-mar., p.36-45

OLIVEIRA, R.S. 2006. Flora da Cadeia do Espinhaço: Zephyranthes Herb. \& Habranthus Herb. (Amaryllidaceae). Dissertação de Mestrado, Botânica, USP, $165 p$. 
OLIVEIRA, P.E.; BEHLING, H.; LEDRU, M.-P.; BARBERI, M.; BUSH, M.; SALGADO-LABOURIAU, M.L.; GARCIA, M.J.; MEDEANIC, S.; BARTH, O.M., BARROS, M.A. \& SCHEEL-YBERT, R. 2005. Paleovegetação e paleoclimas do Quaternário do Brasil. In Quaternário do Brasil. (C.R.G. SOUZA et al., eds.). Ribeirão Preto, SP: Holos Editora, p.52-74.

OLIVEIRA, R.B. \& GODOY, S.A.P. 2007. Composição florística dos afloramentos rochosos do Morro do Forno, Altinópolis, São Paulo. Biota Neotropica 7(2) http://www.biotaneotropica.org.br/v7n2/pt/abstract?article+bn00507022007

PENNINGTON, R.T.; LAVIN, M.; PRADO, D.E.; PENDRY, C.A.; PELL, S.K. \& BUTTERWORTH, C.A. 2004. Historical climate change and speciation: neotropical seasonally dry forest plants show patterns of both Terciary and Quaternary diversification. Philosophical Transactions of the Royal Society B, DOI $10.1098 /$ rstb.2003.1435

PENNINGTON, R.T., PRADO, D.E. \& PENDRY, C.A. 2000. Neotropical seasonally dry forests and Quaternary vegetation changes. Journal of Biogeography 27:261273.

PERON, M.V. 1989. Listagem preliminar da flora fanerogâmica dos campos rupestres do Parque Estadual do Itacolomi - Ouro Preto/Mariana, MG. Rodriguésia 67(41):63-69.

PIVELLO, V.R.; SHIDA, C.N. \& MEIRELLES, S.T. 1999. Alien grasses in Brazilian savannas: a threat to the biodiversity. Biodiversity and Conservation, v.8, p. 12811294 
POREMBSKI, S. \& BARTHLOTT, W. 1997. Seasonal dynamics of plant diversity on inselbergs in the Ivory Coast (West Africa). Botanica Acta, v.110, p.466-472

POREMBSKI, S. \& BARTHLOTT, W. 2000. Granitic and gneissic outcrops (inselbergs) as centers of diversity for desiccation-tolerant vascular plants. Plant Ecology 151:19-28.

POREMBSKI, S. 2007. Tropical inselbergs: habitat types, adaptative strategies and diversity patterns. Revista Brasileira de Botânica 30(4):579-586.

POREMBSKI, S., BARTHLOTT, W., DÖRRSTOCK, S. \& BIEDINGER, N. 1994. Vegetation of rock outcrops in Guinea: granite inselbergs, sandstone table mountains and ferricretes - remarks on species number and endemism. Flora 189:315-326.

POREMBSKI, S., MARTINELLI, G., OHLEMÜLLER, R. \& BARTHLOTT, W. 1998. Diversity and ecology of saxicolous vegetation mats on inselbergs in the Brazilian Atlantic rainforest. Diversity and Distributions 4:107-119.

POREMBSKI, S.; SEINE, R. \& BARTHLOTT, W. 1997b. Inselberg vegetation and the biodiversity of granite outcrops. Journal of the Royal Society of Western Australia, v.80, p.193-199.

PORTO, P.A.F.; ALMEIDA, A.; PESSOA, W.J. TROVÃO, D. \& FELIX, L.P. 2008. Composição florística de um inselbergue no agreste paraibano, município de Esperança, nordeste do Brasil. Caatinga, v.21, n.2, p.214-222, abr.-jun.

PORTO, M.L. \& SILVA, M.F.F. 1989. Tipos de vegetação metalófila em áreas da Serra de Carajás e de Minas Gerais, Brasil. Acta botanica brasilica 3(2):13-21. 
POTT, A., SILVA, J.S.V., SALIS, S.M., POTT, V.J. \& SILVA, M.P. 2000. Vegetação e uso da terra. In Zoneamento ambiental da borda oeste do Pantanal: maciço do Urucum e adjacências (J.S.V. Silva, org.). Brasília, DF, Embrapa Comunicação para Transferência de Tecnologia, p.111-131.

PRADO, D.E. \& GIBBS, P.E. 1993. Patterns of species distributions in the dry seasonal forests of South America. Annals of the Missouri Botanical Garden, v.80, p. $902-927$

QUEIROZ, L.P., SENA, T.S.N. \& COSTA, M.J.S.L. 1996. Flora vascular da Serra da Jibóia, Santa Terezinha - Bahia. I. O campo rupestre. Sitientibus 15:27-40.

RAPINI, A.; MELLO-SILVA, R. \& KAWASAKI, M.L. 2002. Richness and endemism in Asclepiadoideae (Apocynaceae) from the Espinhaço Range of Minas Gerais, Brazil - a conservationist view. Biodiversity and Conservation, v.11, p.1733-1746

RATTER, J.A.; POTT, A.; POTT, V.J.; CUNHA, C.N. \& HARIDASAN, M. 1988. Observations on woody vegetation types in the Pantanal and at Corumbá, Brazil. Notes RBG Edinb., v.45, n.3, p.503-525

RAYOL, B.P. 2006. Análise florística e estrutural da vegetação xerofítica das savanas metalófilas na Floresta Nacional de Carajás: subsídios à conservação. Dissertação de Mestrado, Universidade Rural da Amazônia e Museu Paraense Emílio Goeldi, Pará. 
RIBEIRO, K.T., MEDINA, B.M.O. \& SCARANO, F.R. 2007. Species composition and biogeographic relations of the rock outcrop flora on the high plateau of Itatiaia, SE-Brazil. Revista Brasileira de Botânica 30(4):623-639.

RIZZINI, C.T. 1997. Tratado de fitogeografia do Brasil: aspectos ecológicos, sociológicos e florísticos. Âmbito Cultural Edições Ltda., Rio de Janeiro, 2.ed.

ROCHA. A.E.S. \& SECCO, R.S. 2004. Contribuição à taxonomia de Axonopus P.Beauv. (Poaceae) no estado do Pará, Brasil. Acta botanica brasilica, v.18, n.2, p.295-304.

SAADI, A.; BEZERRA, F.H.R.; COSTA, R.D.; IGREJA, H.L.S. \& FRANZINELLI, E. 2005. Neotectônica da Plataforma Brasileira. In Quaternário do Brasil. (C.R.G. SOUZA et al., eds.). Ribeirão Preto, SP: Holos Editora, p. 211-234.

SAFFORD, H.D. 2007. Brazilian Páramos IV.Phytogeography of the campos de altitude. Journal of Biogeography 34:1-22

SCHNEIDER, A.A.; HEIDEN, G. \& BOLDRINI, I.I. 2009. Notas nomenclaturais em Baccharis L. sect. Caulopterae DC. (Asteraceae). Revista Brasileira de Biociências, v.7, n.2., p.225-228, abr.-jun.

SECCO, R.S. \& MESQUITA, A.L. 1983. Notas sobre a vegetação de canga na Serra Norte - I. Boletim do Museu Paraense Emílio Goeldi 59:1-13.

SEINE, R.; BECKER, U.; POREMBSKI, S.; FOLLMANN, G. \& BARTHLOTT, W. 1998. Vegetation of inselbergs in Zimbabwe. Edinburgh Journal of Botany, v.55, n.2, p.267-293 
SEMIR, J. 1991. Revisão taxonômica de Lychnophora Mart. (Vernoniae:

Compositae). Tese de doutorado, UNICAMP, São Paulo.

SILVA, M.F.F. 1991. Anállise florística da vegetação que cresce sobre canga hematítica em Carajás - Pará (Brasil). Boletim do Museu Paraense Emílio Goeldi, série Botânica 7(1):79-107.

SILVA, M.F.F. 1992. Distribuição de metais pesados na vegetação metalófita de Carajás. Acta botanica brasilica 6(1):107-122.

SILVA, M.F.F., SECCO, R.S. \& LOBO, M.G. 1996. Aspectos ecológicos da vegetação rupestre da Serra dos Carajás, Estado do Pará, Brasil. Acta Amazonica 26(1/2):17-44.

SMITH, N. et al. (eds.). 2004. Flowering plants of the neotropics. Princetown University Press.

SORIANO, B.M.A. 2000. Climatologia. In Zoneamento ambiental da borda oeste do Pantanal: maciço do Urucum e adjacências (J.S.V. SILVA, org.). Brasília, DF, Embrapa Comunicação para Transferência de Tecnologia, p.69-81.

SPICHIGER, R.; CALENGE, C. \& BISE, B. 2004. Geographical zonation in the Neotropics of tree species characteristic of the Paraguay-Paraná Basin. Journal of Biogeography, v.31, p.1489-1501

SUGUIO, K. 2005. Introdução. In Quaternário do Brasil. (C.R.G. SOUZA et al., eds.). Ribeirão Preto, SP: Holos Editora, p.21-27. 
THE INTERNATIONAL PLANT NAMES INDEX. Disponível em: <HTTP:/ / www.ipni.org.>. Acesso em: 10 dez. 2008.

THE MISSOURI BOTANICAL GARDEN. Disponível em: <HTTP:/ / www.tropicos.org.>. Acesso em: 10 dez. 2008.

VELOSO, H.P., RANGEL FILHO, A.L.R. \& LIMA, J.C.A. 1991. Classificação da vegetação brasileira, adaptada a um sistema universal. Departamento de Recursos Naturais e Estudos Ambientais, Instituto Brasileiro de Geografia e Estatística, Rio de Janeiro.

VIANA, P.L. \& LOMBARDI, J.A. 2007. Florística e caracterização dos campos rupestres sobre canga na Serra da Calçada, Minas Gerais, Brasil. Rodriguesia 58(1):159-177.

VINCENT, R.C. \&MEGURO, M. 2008. Influence of soil properties on the abundance of plant species in ferruginous rocky soils vegetation, southeastern Brazil. Revista Brasileira de Botânica, v.31, n.3, p.377-388, jul.-set.

VINCENT, R.C. 2004. Florística, fitossociologia e relações entre a vegetação e o solo em áreas de campos ferruginosos no Quadrilátero Ferrífero, Minas Gerais. Tese de doutorado, Universidade de São Paulo, São Paulo.

WALDEMAR, C.C. 1998. A vegetação rupestre heliófila do Parque Estadual de Itapuã, Viamão, RS. Dissertação de mestrado, UFRGS, Rio Grande do Sul. ZANIN, A. \& LONGHI-WAGNER, H. M. 2006. Sinopse do gênero Andropogon L. (Poaceae - Andropogoneae) no Brasil. Revista Brasileira de Botânica, v.29, n.2, p.289-299, abr.-jun. 
ZAPPI, D.C., LUCAS, E., STANNARD, B.L., LUGHADHA, E.N., PIRANI, J.R., QUEIROZ, L.P., ATKINS, S., HIND, D.J.N., GIULIETTI, A.M., HARLEY, R.M. \& CARVALHO, A.M. 2003. Lista das plantas vasculares de Catolés, Chapada Diamantina, Bahia, Brasil. Boletim de Botânica da Universidade de São Paulo 21(2):345-398. 
Anexo - Relação de trabalhos consultados para a elaboração da matriz para análises de cluster. Localização das áreas, coordenadas geográficas, número total de espécies amostradas ( $\left.n^{\circ} \mathrm{spp}\right)$, abreviaturas utilizadas, habitats considerados nas análises e referência bibliográfica.

\begin{tabular}{|c|c|c|c|c|c|}
\hline Local & Coordenada geográfica & $\mathrm{N}^{\mathrm{o}} \mathrm{spp}$ & Abreviatura & Habitats amostrados & Referência bibliográfica \\
\hline Morro Sapucaia, Sapucaia do Sul, e Morro & $29^{\circ} 50^{\prime} \mathrm{S}, 51^{\circ} 06^{\prime} \mathrm{W}$ e & 62 e 53 & D1 & & Fernandes\&Batista 1988 \\
\hline do Cabrito, Montenegro RS & $29^{\circ} 38^{\prime} \mathrm{S}, 51^{\circ} 39^{\prime} \mathrm{W}$ & & & & \\
\hline Casa de Pedra, Bagé, RS & $30^{\circ} 58^{\prime} 07^{\prime \prime} \mathrm{S}, 53^{\circ} 35^{\prime} 21^{\prime \prime} \mathrm{W}$ & 119 & D2 & & Fernandes \& Baptista 1999 \\
\hline Fazenda Padre Eterno, Morro Reuter, RS & $\begin{array}{l}29^{\circ} 30^{\prime}-29^{\circ} 35^{\prime} \mathrm{S} \\
50^{\circ} 55^{\prime}-51^{\circ} 00^{\prime} \mathrm{W}\end{array}$ & 126 & D3 & & Bauer \& Larocca 2003 \\
\hline Corumbá e Ladário, MS & $19^{\circ} 06^{\prime}-19^{\circ} 16^{\prime} \mathrm{S}, 57^{\circ} 31^{\prime}-57^{\circ} 34^{\prime} \mathrm{W}$ & 171 & $\mathrm{C} 1$ & & Presente estudo \\
\hline Barão de Cocais, MG & $\begin{array}{l}19^{\circ} 53^{\prime} 08^{\prime \prime} \mathrm{S} 43^{\circ} 26^{\prime} 11,22^{\prime \prime} \mathrm{W} \\
\text { e } 19^{\circ} 51^{\prime} 06,94^{\prime \prime} \mathrm{S} 43^{\circ} 22^{\prime} 35,45^{\prime \prime} \mathrm{W}\end{array}$ & 117 & $\mathrm{C} 2$ & & Mourão \& Stehmann 2008 \\
\hline $\begin{array}{l}\text { Morro do Cachimbo, Serra da Mutuca } \\
\text { (PESerra Rola Moça),MG }\end{array}$ & $20^{\circ} 01^{\prime} \mathrm{S}, 43^{\circ} 59^{\prime} \mathrm{W}$ & 54 & $\mathrm{C} 3$ & Canga couraçada & Vincent \& Meguro 2008 \\
\hline $\begin{array}{l}\text { Serra do Rola-Moça, Serra do Curral } \\
\text { (PESerra Rola-Moça), MG }\end{array}$ & $20^{\circ} 03^{\prime} \mathrm{S}, 44^{\circ} 01^{\prime} \mathrm{W}$ & 155 & $\mathrm{C} 4$ & Canga nodular & Vincent \& Meguro 2008 \\
\hline Serra da Calçada, Serra da Moeda, MG & $20^{\circ} 06^{\prime} \mathrm{S}, 43^{\circ} 59^{\prime} \mathrm{W}$ & 134 & Q1 & $\begin{array}{l}\text { Campo rupestre } \\
\text { quartzitico }\end{array}$ & Vincent \& Meguro 2008 \\
\hline $\begin{array}{l}\text { Serra da Calçada (Quadrilátero Ferrífero), } \\
\text { Brumadinho, MG }\end{array}$ & idem & 210 & C5 & Canga nodular & Viana \& Lombardi 2007 \\
\hline $\begin{array}{l}\text { Serra da Calçada (Quadrilátero Ferrífero), } \\
\text { Brumadinho, MG }\end{array}$ & $20^{\circ} 05^{\prime} 35^{\prime \prime} \mathrm{S}, 43^{\circ} 59^{\prime} 01^{\prime \prime} \mathrm{W}$ & 153 & C6 & Canga couraçada & Viana \& Lombardi 2007 \\
\hline $\begin{array}{l}\text { Serra da Calçada (Quadrilátero Ferrífero), } \\
\text { Brumadinho, MG }\end{array}$ & idem & 93 & $\mathrm{C} 7$ & Capões & Viana \& Lombardi 2007 \\
\hline P.E.S.R.Moça & $20^{\circ} 03^{\prime} 60^{\prime \prime} \mathrm{S}, 44^{\circ} 02^{\prime} 00^{\prime \prime} \mathrm{W}$ & 32 & $\mathrm{C} 8$ & & Jacobi et al.2008 \\
\hline Quadrilátero Ferrífero, MG & $19^{\circ} 30^{\prime}-20^{\circ} 31^{\prime} \mathrm{S}, 43^{\circ} 00^{\prime}-44^{\circ} 30^{\prime} \mathrm{W}$ & 160 & C9 & & Jacobi et al.2007 \\
\hline
\end{tabular}


continuação Anexo

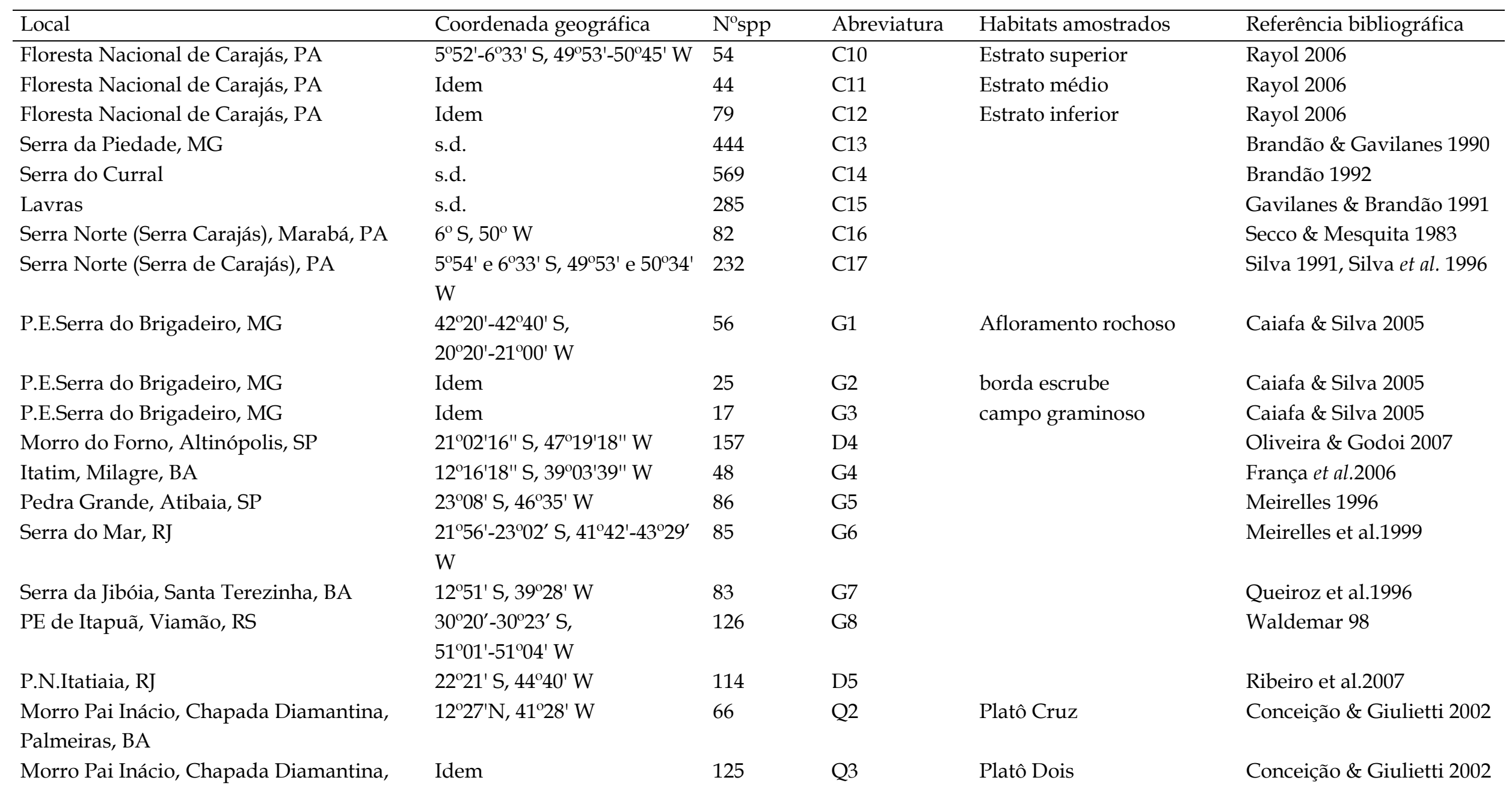

Palmeiras, BA 
continuação Anexo

\begin{tabular}{|c|c|c|c|c|}
\hline Local & Coordenada geográfica & $\mathrm{N}^{\circ} \mathrm{spp}$ & Abreviatura Habitats amostrados & Referência bibliográfica \\
\hline Chapada Diamantina, BA & $12^{\circ} 27^{\prime} \mathrm{S}, 41^{\circ} 28^{\prime} \mathrm{W}$ & 135 & Q4 & Conceição et al. 2007b \\
\hline Chapada Diamantina & $\begin{array}{l}12^{\circ} 35^{\prime} 3,8^{\prime \prime}-12^{\circ} 35^{\prime} 25,6^{\prime \prime} \mathrm{S}, \\
41^{\circ} 23^{\prime} 24,8^{\prime \prime}-41^{\circ} 233^{\prime} 35,8^{\prime \prime} \mathrm{W}\end{array}$ & 57 & Q5 & Neves \& Conceição 2007 \\
\hline Quixadá, Ceará & $04^{\circ} 57^{\prime} 20,6^{\prime \prime} \mathrm{S}, 39^{\circ} 01^{\prime} 28^{\prime \prime} \mathrm{W}$ & 77 & GG109 & Araújo et al. 2008 \\
\hline Petrolândia, PE & $09^{\circ} 05^{\prime} 27^{\prime \prime} \mathrm{S}, 38^{\circ} 13^{\prime} 43^{\prime \prime} \mathrm{W}$ & 95 & G11 & Silva et al. 2009 \\
\hline Caruaru, PE & $08^{\circ} 14^{\prime} \mathrm{S}, 35^{\circ} 55^{\prime} \mathrm{W}$ & 62 & G12 & Araújo et al. 2005 \\
\hline Serra da Jibóia, Feira de Santana, BA & $12^{\circ} 16^{\prime} 18^{\prime \prime} \mathrm{S}, 39^{\circ} 03^{\prime} 39^{\prime \prime} \mathrm{W}$ & 48 & G13 & França et al.2005 \\
\hline
\end{tabular}




\section{Considerações Finais}

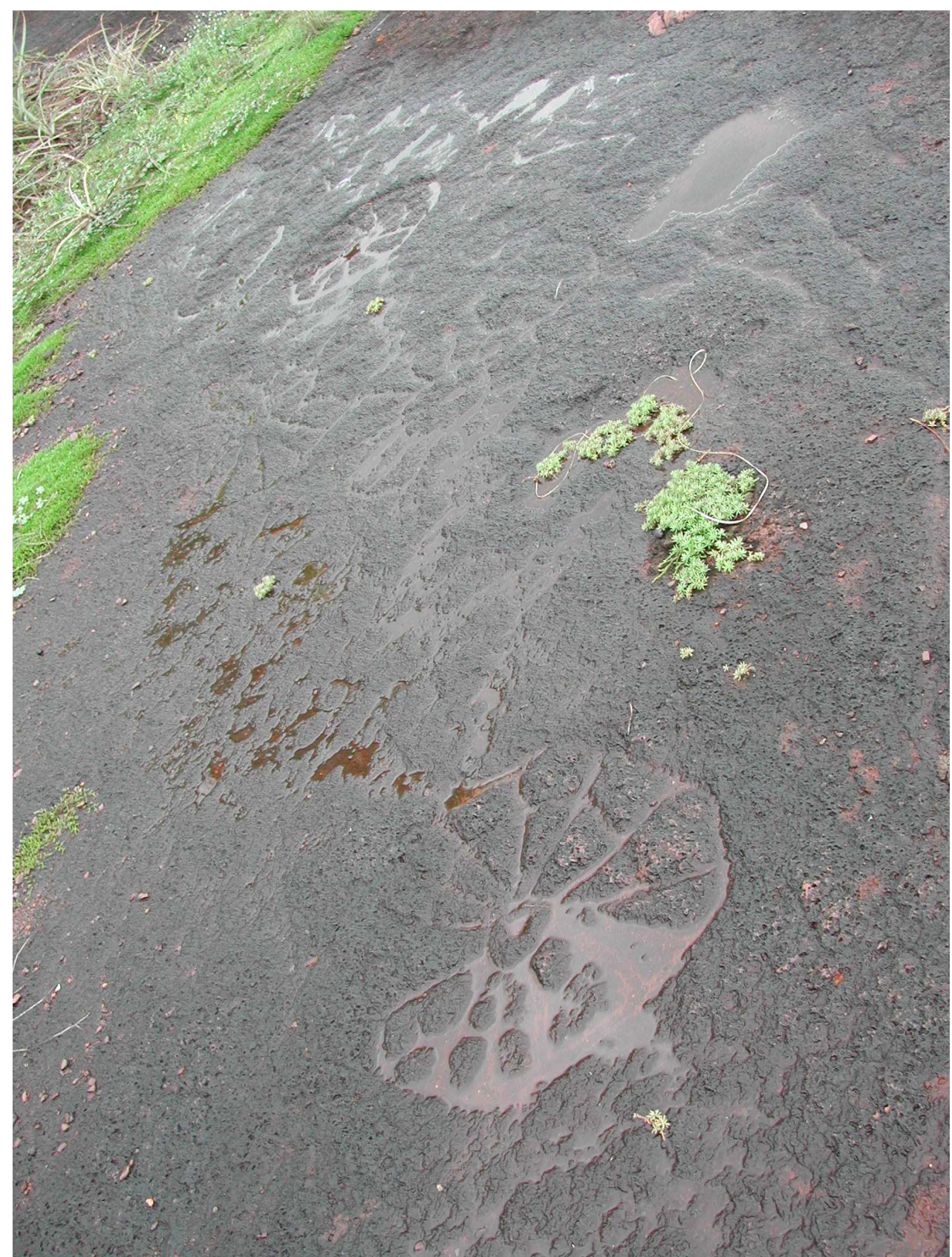

Petrogrifo na Fazenda Figueira, Corumbá, MS. 
Amostraram-se 188 espécies de plantas vasculares nas cangas de Corumbá, MS, com predomínio de Fabaceae e Poaceae, denotando um caráter campestre a esta vegetação. De forma diversa de outros afloramentos rochosos houve o predomínio de formas de vida de maior porte, sobretudo nanofanerófitas, microfanerófitas além de hemicriptófitas.

A composição florística das cangas deu-se por representantes de outras formações vegetais, como as matas deciduais e semideciduais, sendo registradas apenas duas espécies com distribuição restrita: Gomphrena centrota e Discocactus ferricola.

A diferença na composição florística entre os três afloramentos estudados foi grande, pois cerca de $40 \%$ das espécies estiveram restritas a uma única localidade estudada.

Algumas espécies do estrato herbáceo ocorreram em locais com maior proporção de rocha exposta, como Discocactus ferricola, Gomphrena centrota, Polycarpae corymbosa, Selaginella sellowii e Portulaca sp1. A maioria das espécies, entretanto, esteve associada a ambientes com a presença de substrato fino. Estes resultados foram evidenciados quando da análise dos dois habitats da Fazenda Banda Alta, com a segregação das plantas em ambientes "encharcados" daquelas em ambientes "secos".

A forma de ocupação da vegetação, seja como estrato herbáceo ou como ilhas de solo, influencia a composição e cobertura das espécies. Este resultado também pode ser inferido pelo baixo número de espécies compartilhado pelos 
dois ambientes (cerca de 35\% do total de espécies), assim como pelo elevado número de espécies registradas exclusivamente em ilhas de solo (40\%).

Três espécies definiram a composição e organização das ilhas de solo: Selaginella sellowii, Deuterocohnia meziana e Bromelia balansae. A primeira pode constituir ilhas monoespecíficas e propiciar o estabelecimento de outras plantas. A segunda associa-se a poucas espécies herbáceas, notadamente ligadas à uma maior proporção de superfície rochosa e, eventualmente, a umas poucas espécies arbustivas, tais como: Bauhinia pentandra, Astronium fraxinifolium, Commiphora leptophloeos, Jacaranda cuspidifolia e Talisia esculenta. E a terceira, sempre esteve associada a elementos arbustivo-arbóreos, podendo constituir os maiores agrupamentos. Nas ilhas de solo maiores foram encontrados valores elevados de cobertura de Bromelia balansae e de espécies arbustivo-arbóreas.

As ilhas de solo com Deuterocohnia meziana segregaram-se daquelas com Bromelia balansae no gradiente emergido das análises de ordenação. Outro resultado interessante foi a separação entre ilhas herbáceas de ilhas arbustivoarbóreas na Fazenda São Sebastião do Carandá.

O grau de cobertura e a composição de espécies nas ilhas de solo foram influenciadas pelo tamanho insular, assim como verificaram-se relações positivas entre o número de espécies e a área insular. Estes dados sugerem que a área da ilha de solo influencia a composição e a cobertura das espécies das cangas.

A vegetação das cangas de Corumbá é mais próxima em termos de similaridade às de granito-gnaisses do Nordeste brasileiro e do Rio de Janeiro do que em relação aos demais afloramentos. Prado \& Gibbs (1993), Pennington et al. (2000, 2004) e Spichiger et al. (2004) aventaram a hipótese de ocorrência de um arco 
seco formado pelas florestas estacionais, desde a Caatinga brasileira, cruzando o Cerrado até os vales secos dos Andes, o que poderia explicar essa semelhança florística entre as cangas de Corumbá e a Caatinga. No entanto, estes autores não abordam a distribuição de espécies herbáceas de ambientes xéricos ou aquelas em afloramentos rochosos.

O que este trabalho procurou mostrar foi que esta similitude entre a vegetação das cangas de Corumbá e daquelas da Caatinga reflete a atuação de fatores paleogeográficos e, secundariamente, de interações diretas dessas vegetações com a matriz rochosa, cabendo ressaltar ainda o fato de nas primeiras a composição da rocha ser ferruginosa e, naquelas, graníticas - distinção a demandar maiores estudos.

A hipótese de as vegetações das cangas de Corumbá e as da caatinga terem estado unidas em épocas pretéritas mais secas e, atualmente, restringirem-se a nichos xéricos, como a própria caatinga e os afloramentos rochosos, ainda que sob um regime climático mais úmido, foi aventada por Ab'Sáber (1988) ao discorrer sobre a origem geomorfológica da bacia sedimentar do Pantanal. E o resultado a que chegamos, embora não chegue a ser surpreendente, abre novas e promissoras perspectivas à pesquisa, das quais a mais interessante é aplicá-la in loco, com enfoques multidisciplinares, além de estudos filogeográficos para estas comunidades vegetais. 


\section{Referências bibliográficas}

Ab'Sáber, A.N. 1988. O Pantanal Mato-grossense e a teoria dos refúgios. Revista Brasileira de Geografia 50(1/2): 9-57.

PENNINGTON, R.T.; LAVIN, M.; PRADO, D.E.; PENDRY, C.A.; PELL, S.K. \& BUTTERWORTH, C.A. 2004. Historical climate change and speciation: neotropical seasonally dry forest plants show patterns of both Terciary and Quaternary diversification. Philosophical Transactions of the Royal Society B, DOI $10.1098 /$ rstb.2003.1435

PENNINGTON, R.T., PRADO, D.E. \& PENDRY, C.A. 2000. Neotropical seasonally dry forests and Quaternary vegetation changes. Journal of Biogeography 27:261273.

PRADO, D.E. \& GIBBS, P.E. 1993. Patterns of species distributions in the dry seasonal forests of South America. Annals of the Missouri Botanical Garden, v.80, p. $902-927$

SPICHIGER, R.; CALENGE, C. \& BISE, B. 2004. Geographical zonation in the Neotropics of tree species characteristic of the Paraguay-Paraná Basin. Journal of Biogeography, v.31, p.1489-1501 


\section{Conclusões}

A composição florística das cangas de Corumbá é influenciada pela vegetação da mata decidual de seu entorno.

A composição de espécies e abundância é determinada pela forma de ocupação destes afloramentos: como estrato herbáceo ou como ilhas de solo.

A proporção de substrato rochoso exposto afeta a composição e a cobertura das espécies em ilhas de solo.

A relação entre o número de espécies vasculares e a área insular é positiva e melhor definida pela função potência.

A relação verificada entre a área e o número de espécies nas unidades insulares não permite rejeitar quaisquer dos modelos preditivos utilizados na biogeografia de ilhas baseados nas hipóteses de heterogeneidade ambiental ou amostragem passiva.

A composição florística da maioria das cangas, em nível de famílias e de gêneros, é distinta daquela encontrada em granitos e apresenta alguma sobreposição com a de quartzitos.

O efeito predominante do substrato na composição florística das cangas não foi corroborado, dada a maior similaridade das cangas de Corumbá com os afloramentos graníticos da Caatinga. 
Não ando pelo mundo a lastimar

O que o mundo lastima em demasia:

Que os meses sejam de vácuo

E o chão seja de lama

e podridão.

A gemer e acovardar-se,

Cheio de pós para inválidos,

O conformismo pode ficar bem

Para os de quarta categoria;

Eu ponho o meu chapéu como bem quero,

Dentro ou fora de portas.

Por que iria eu rezar?

Por que haveria eu de me curvar

E fazer rapapés?

Walt Whitman (Estados Unidos, 1819 - 1892; in:

Folhas das Folhas de Relva, trad. Geir Campos,

Brasiliense, 1983) 